\title{
Diary of an Ardent Naturalist: Letters from Austin H. Clark to his Wife from the 1906 Research Cruise of the Steamer Albatross
}

\author{
DAVID L. PAWSON and DORIS J. PAWSON
}

\section{Introduction}

Austin Hobart Clark (1880-1954) was a marine biologist who specialized in the study of echinoderms (sea stars and allies), but his broad research interests led him to become an expert in several animal groups. He was a $\mathrm{Cu}-$ rator in the National Museum of Natural History, Smithsonian Institution, Washington, D.C., from 1908 until his retirement in 1950, and a Research Associate until his death in late 1954.

A large collection of the papers of Austin Hobart Clark resides in the Smithsonian Institution Archives (SIARU007183). In 2007, we were fortunate to receive a second collection of the papers of Austin Clark from the late Mrs. Stella Clark, of Sperryville, Va. Stella Clark was the widow of Hugh U. Clark, Austin Clark's second son. This additional collection was initially deeded to the National Museum of Natural History, and it will become part of the Austin Clark papers

The authors are in the Department of Invertebrate Zoology, MRC163, National Museum of Natural History, Smithsonian Institution, Washington D.C. 20013-7012 (email: Pawsond@, si.edu).

doi: https://doi.org/10.7755/MFR.80.4.1

ABSTRACT-The United States Fish Commission Steamer Albatross (18821921) conducted research in the Western Atlantic Ocean, Gulf of Mexico, and Pacific Ocean. On board during the many research cruises was a "veritable Who's Who of American zoologists" (Hedgpeth, 1945). The eventful 1906 cruise, from San Francisco to Alaska, Japan, and back to San Francisco, took 7 long months. It began with the great San Francisco earthquake on 18 April, and then, near its end, the ship's captain, LeRoy M. Garrett, was lost overboard. in the Smithsonian Archives. We were astonished to find among the papers the letters, noted above, from Clark on the Albatross to his wife Mary. Regrettably, none of Mary Clark's numerous replies to her husband appear to have survived.

Our interest in Clark's personal and professional life, and in the Albatross (Fig. 1), was stimulated by this collection of letters, for they describe, in intimate and gossipy detail, life aboard the vessel, interpersonal relationships, shore excursions, and the collecting of marine specimens. Diaries and letters revealing details of life on board the Albatross are not common and, while some are available for study in various archives (for example, diaries of $\mathrm{P}$. Bartsch in the Smithsonian Institution; W. K. Fisher in the California Academy of Sciences; J. O. Snyder in the Stanford University Archives; C. A. Kofoid in the Archives of the Scripps Institution of Oceanography), they are not generally available for public consumption.

A notable exception is the fanatical diarist Alexander Agassiz, who published his diaries from his cruises on the USCGS Steamer Blake (Agassiz, 1888), and whose Albatross cruise diaries are extensively quoted in G. Agas-

During the cruise, extensive collections of marine and terrestrial organisms were acquired. These events, and many others, were faithfully reported by young naturalist Austin Hobart Clark in numerous affectionate letters to his wife, Mary Wendell Upham Clark. The letters, donated to the Smithsonian Institution in 2007, are an intimate and fascinating diary of life aboard the ship; they report on interpersonal relationships, visits ashore, and scientific research. Unquestionably, this incident-filled Albatross cruise helped to shape Clark's career in science. siz (1913). Published accounts of early deep-sea research cruises, based upon letters home, are rare. Perhaps the best of them, written by Charles Matkin and edited by Philip Rehbock (1992), describes the cruise of the HMS Challenger from the point of view of a crew member. Austin Clark's letters offer unique and fascinating insights into daily life on board the Albatross, and they also reveal how his 7-month cruise helped to shape his life in science.

A few years after his Albatross cruise, Clark wrote a short account of the cruise aimed at the general reader, and sought to publish it, without success (A. H. Clark, in ms.). We have drawn upon this account where indicated, mainly for information on crew members, and for confirmation of details of the cruise itinerary. Then, in 1950, he sent a brief autobiographical note to the Secretary of Harvard College's Class of 1903. We have cited this memoir, where appropriate, as (A. H. Clark, in bio.).

\section{Brief Biography of Austin Hobart Clark}

Information for the following biography was derived from several sources: materials in the Smithsonian Institution Archives and in the possession of the National Museum of Natural History (NMNH); correspondence in the U.S. National Archives and in the Library of Congress between various scientists and Austin Clark; personal reminiscences of Clark family members during and after a "family reunion" held at the NMNH in August, 2006; and reminiscences of scientists at NMNH who had known Austin Clark. 


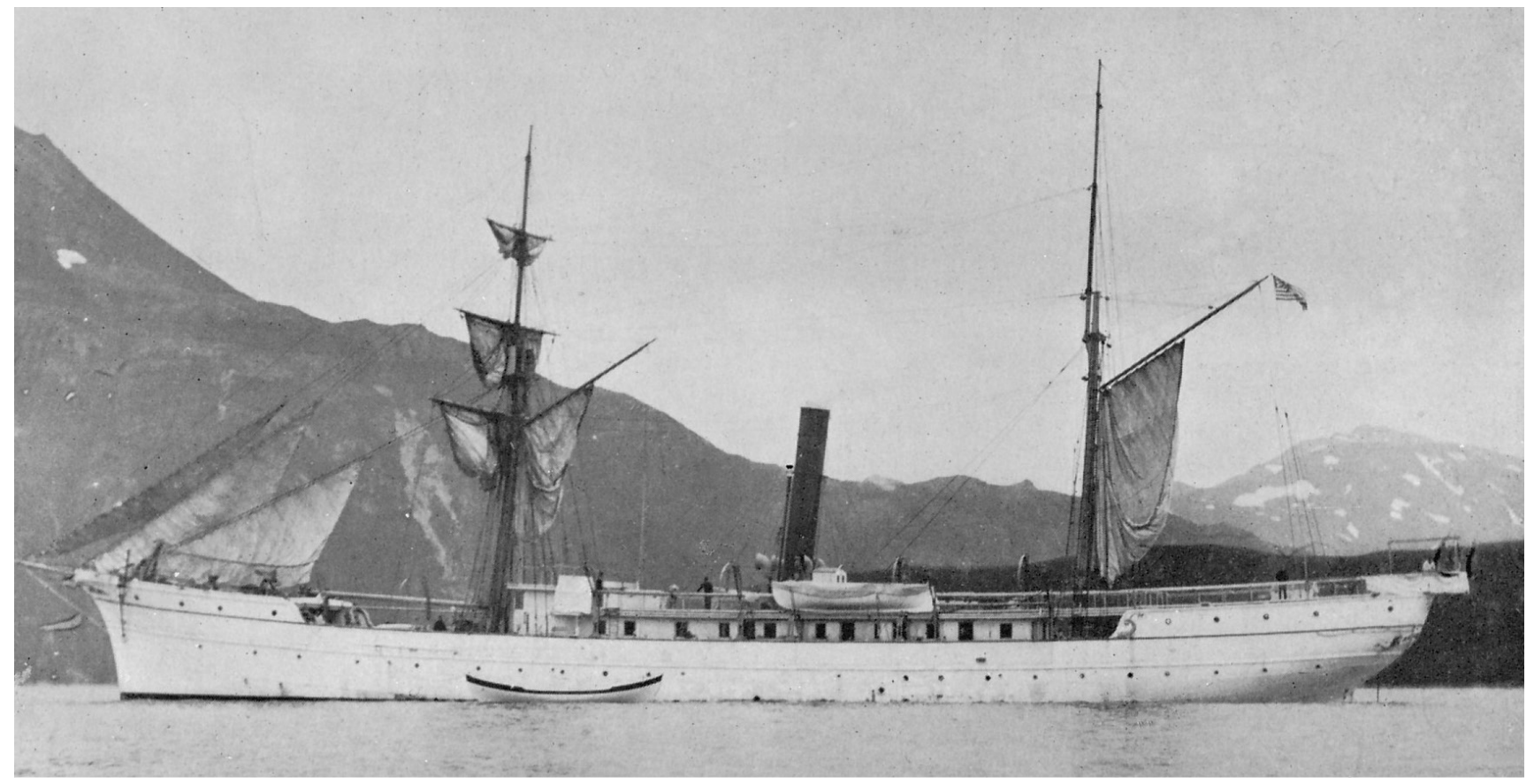

Figure 1.-USFC Steamer Albatross. U.S. National Archives.

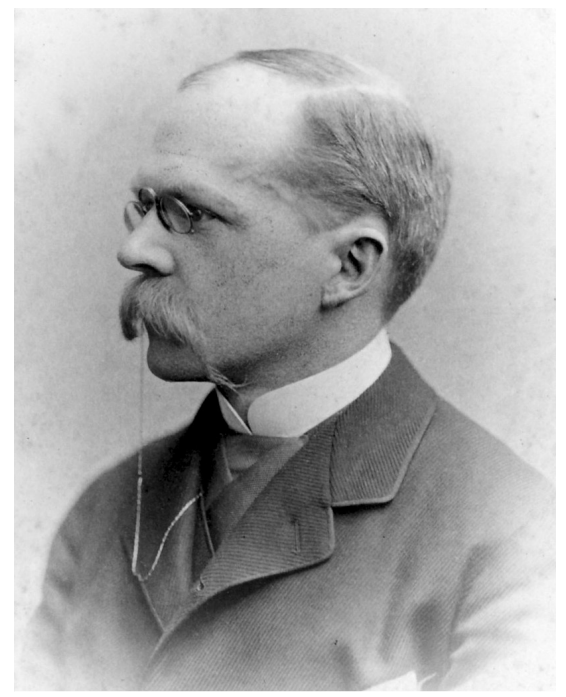

Figure 2.-Theodore M. Clark (1879). Smithsonian Archives.

In 1890, when he was 9 years old, Austin Hobart Clark wrote "Plants: a book about botany." On the first page of this hand-bound pamphlet was this comment: "Preface. This is a book to show you what I know about plants, which is not very much." The author of this modest introduction became a renowned scientist, and his facility with the written word served him well.

Austin Clark was born into privilege in Grantville, Mass. (now incorporated in Wellesley, Mass.), on 17 December 1880. His parents were Theodore Minot Clark (1845-1909; Fig. 2) and Jeanette French Clark (1860-1914; Fig. $3)$. Theodore Clark was a prominent architect, based in Boston, and Austin had two younger sisters, Rosamond and Mildred (Fig. 4).

As a young boy, growing up in Newton, Mass., Clark developed an intense and broad interest in natural history. His parents, ever affectionate and supportive, encouraged him, and he collected birds, birds' eggs, insects, and other animals, and recorded his findings in carefully-written diaries, a few of which are still extant. These notebooks are filled with descriptions and water-color paintings of birds, and details of collecting sites.

Austin attended the high school at Newton, Mass., and then Cutler's School. He entered Harvard College in 1899, and graduated with an A.B. degree in 1903, with a major in Zoolo-

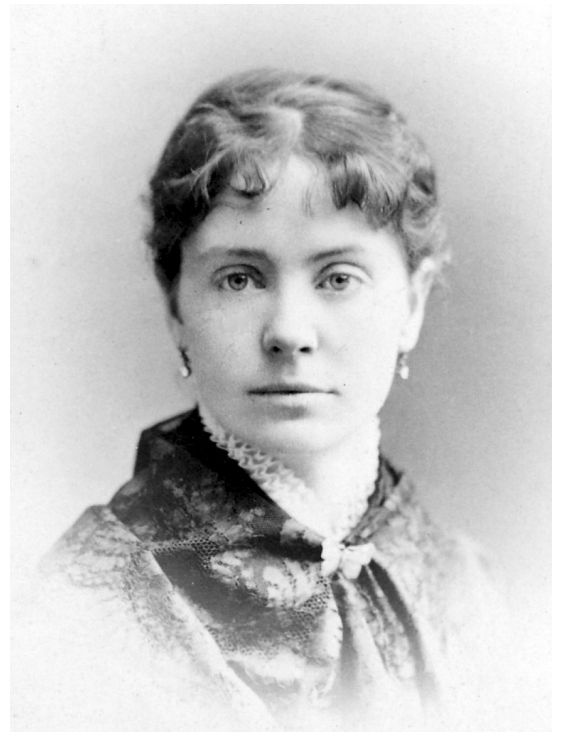

Figure 3.-Jeanette F. Clark (1879). Smithsonian Archives.

gy. His friends at Harvard called him "Texas," for someone had suggested that he had been named after the city of Austin, Tex. During 1902-03, he began graduate studies in genetics, entomology, and ornithology, based in 
Harvard's Museum of Comparative Zoology (MCZ).

In mid-1903, he spent 2 weeks at the Bermuda Biological Station, then in July he traveled to the Lesser Antilles, where he spent 13 months, mostly on the islands of Barbados, St. Vincent, Grenada, and The Grenadines, collecting and studying birds. During this long field trip, he apparently received some financial support from Dr. Outram Bangs, and perhaps others, in the ornithology department at the MCZ. The large bird collection that Clark amassed at that time is deposited in the MCZ.

Clark (Fig. 5) never resumed his graduate studies at Harvard. Upon his return to Boston, he lived at home and worked for several months at Globe Optical-opticians in Boston, noting (A. H. Clark in bio.) that he wished to learn something about "business." During 1905 he wrote several papers on birds, including "The birds of the Southern Lesser Antilles" (Clark, 1905).

Following his return to Boston, he courted Mary Wendell Upham (18811931; Fig. 6) whom he had known for several years. Mary Upham was a first cousin twice removed of Oliver Wendell Holmes Jr., a renowned Associate Justice of the U.S. Supreme Court from 1902 to 1932. Austin and Mary were married on 6 March 1906.

The Clarks had five children (Austin, born 1909; Sarah, born 1911; Hugh, born 1913; Ann, born 1915; and Mary, born 1918). Justice Holmes (known to the Clark children as "Uncle Wendell") played an important role in the education of the children, providing financial assistance to enable them to attend private schools. Mary Wendell Clark died of lung cancer in late 1931; at that time her youngest child, Mary, was 13 years old.

In 1933, Austin Clark married Leila Gay Forbes (1887-1964), a librarian at the Smithsonian Institution. Leila, who was a much-loved stepmother to the five Clark children, later became the Head Librarian of the Smithsonian Institution. She is buried at Evergreen Cemetery at Canton, N.Y., and

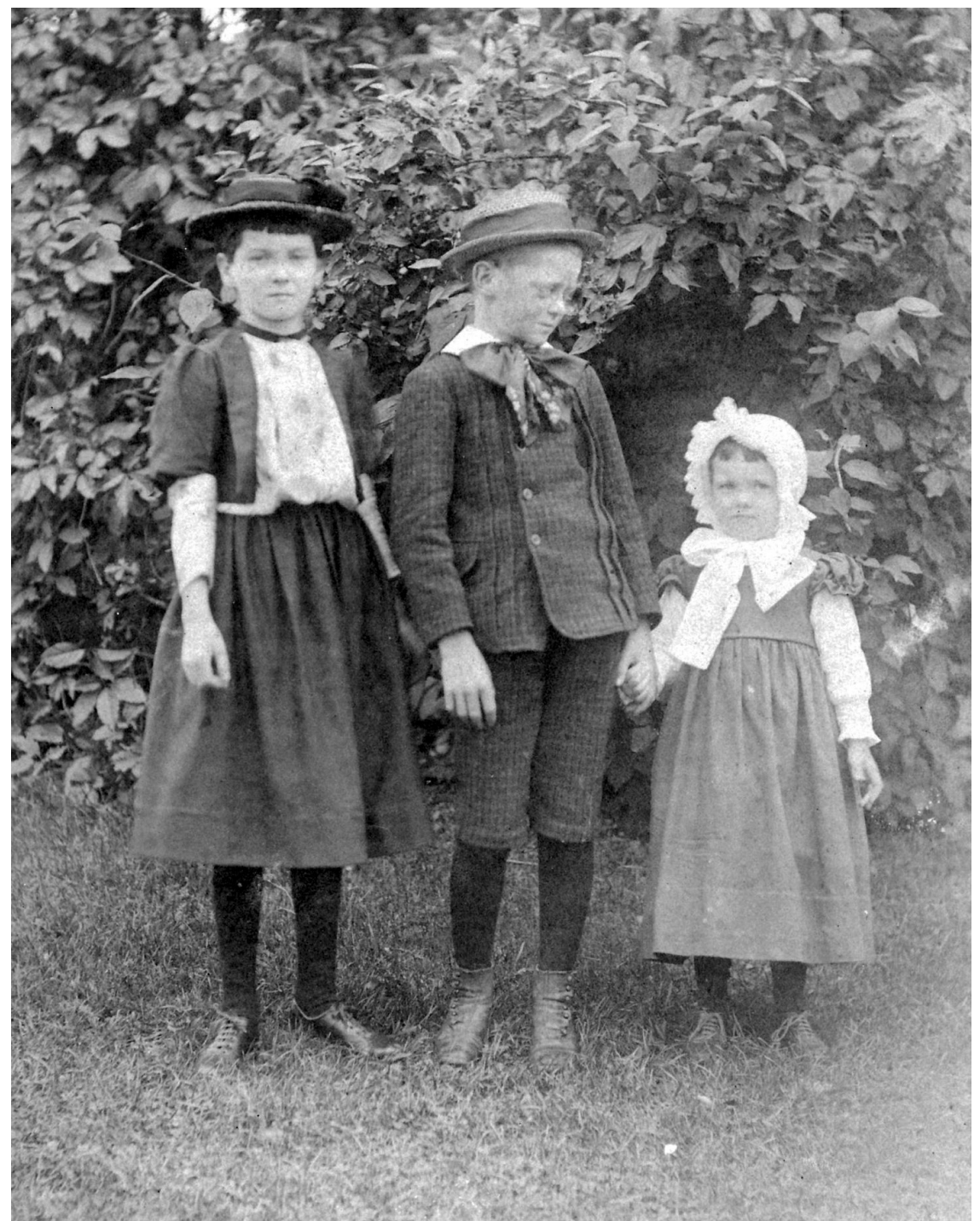

Figure 4.-Austin H. Clark with his sisters Rosamond (left) and Mildred (right), in approximately 1890. Smithsonian Archives.

on her gravestone are the words "five are grateful you came our way."

Clark and his wife were gracious hosts to numerous scientists and students at their home. One of Clark's children noted in an unpublished autobiography (Ann Clark, in ms.) that Clark and his family dressed formally for dinner at home. Clark had a facility with languages - he was fluent in Italian, French, and Russian - and he frequently entertained foreign scientists and dignitaries. His children were often required to speak Italian at meals
(Ann Clark in ms.). In 1921, when Albert, Prince of Monaco visited Washington, D.C. for about 2 weeks, Clark served as his personal aide (A. H. Clark, in bio.).

\section{A.H. Clark Invited to Participate in 1906 Cruise}

Clark's reputation as a field scientist who published excellent papers (i.e., Clark (1905) on birds of various Caribbean islands) had apparently claimed the attention of officials in the U.S. Fish Commission (USFC), 


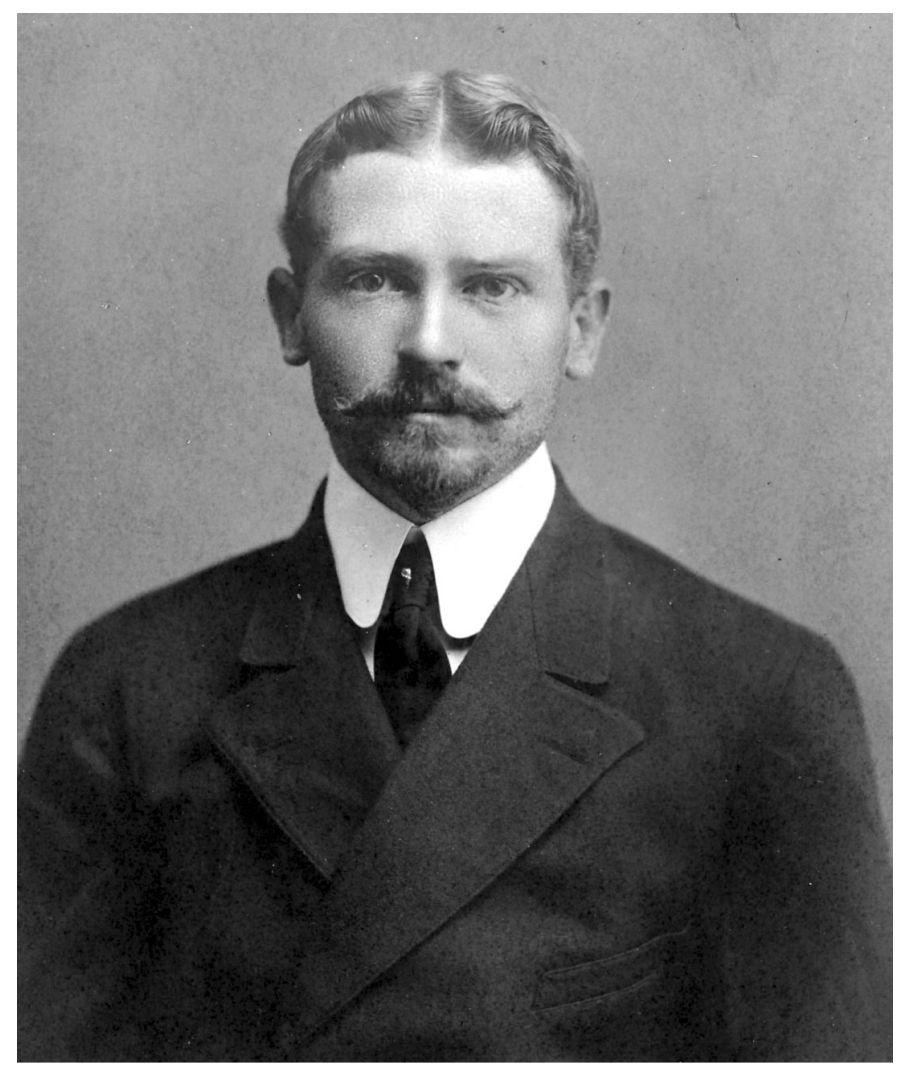

Figure 5.-Austin H. Clark, photographed in Yokohama, Japan, 4 September 1906. Smithsonian Archives.

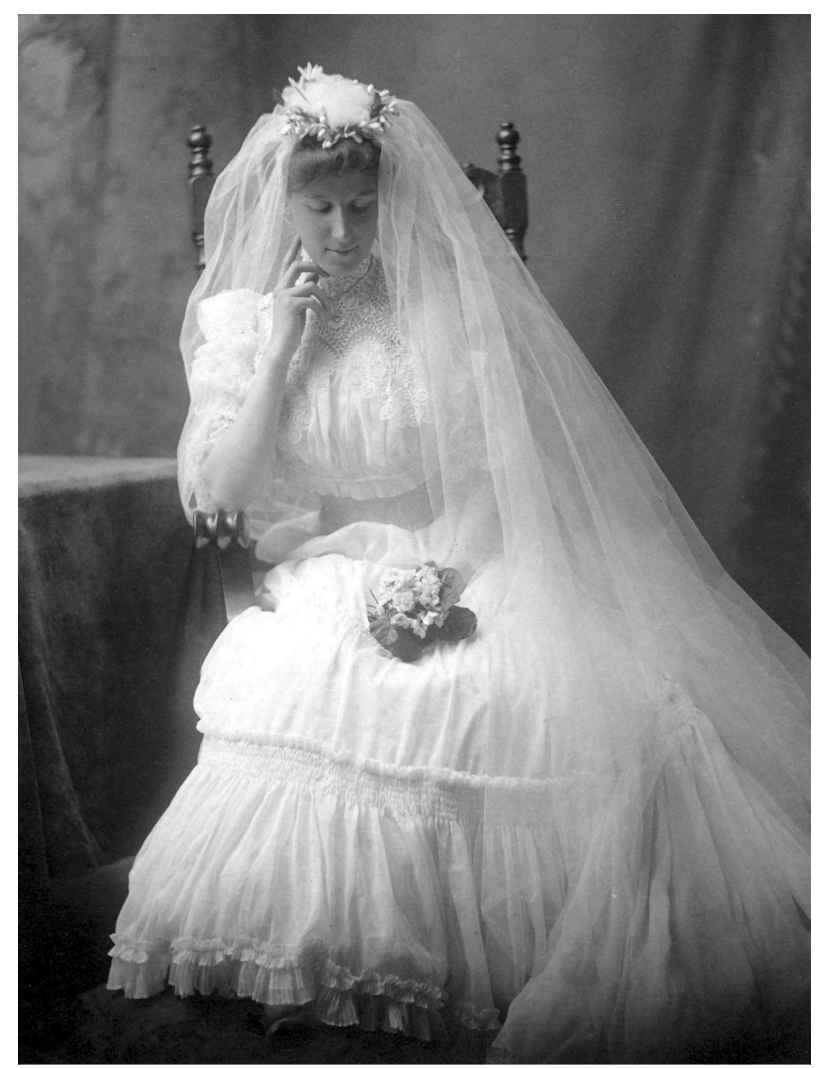

Figure 6.-Austin Clark's wife Mary Wendell Upham Clark, on her wedding day, 6 March 1906. Smithsonian Archives. for he received a letter from Dr. Barton W. Evermann inviting him to join the 1906 Albatross cruise as an assistant naturalist (A. H. Clark in $m s$.) "The Hon. George M. Bowers, Commissioner of Fisheries, offered me the position of clerk of the U.S. Fisheries Steamer Albatross, with the duties of clerk of the naturalists, or chief of the scientific staff. In the civil service of those days the position one held often bore little or no relation to the actual duties performed. So I went to Washington and was duly sworn in on March 17, 1906, leaving immediately for San Francisco where the Albatross was stationed. As a home port of the Albatross was Washington I received a memorandum just as I left saying that I would probably have to refund my travel expenses. But I heard no more of this." (A. H. Clark, in bio.).

The Albatross cruise was scheduled to depart from San Francisco on
18 April 1906, 6 weeks after Clark's marriage. Clark had discussed with his wife and family the possibility of joining the cruise. As might be expected, some family members were strongly opposed to the idea (A. H. Clark in litt.), but apparently both Clark and his wife decided that this cruise might help his planned career as a scientist. After initially turning down Dr. Evermann's offer, Clark accepted a counter-offer (A. H. Clark in bio.). Mary Clark accompanied her husband to San Francisco several days in advance of the ship's sailing, and they stayed with friends in Oakland.

\section{Austin Clark's Scientific Career Following the 1906 Albatross Cruise}

After returning to San Francisco on the Albatross in December, 1906, Clark and his wife moved to Washington, D.C., where he worked for a year in the employ of the U.S. Fish Commission. He spent much of his time during this period writing scientific papers dealing with birds that he collected on the cruise (i.e., Clark, 1907a,b; 1910).

On the recommendation of several colleagues, Clark was hired in 1908 as an assistant curator in the U.S. National Museum, Smithsonian Institution, where he spent the remainder of his career. Clark greatly enjoyed having the Smithsonian Institution as his professional home. In a lifetime of astonishing productivity, he published more than 600 papers on the systematics and biology of a great variety of animals, mostly echinoderms (sea stars and their allies). In addition, he wrote a world monograph on the feather stars, two regional monographs on butterflies, a dozen popular books on natural history, hundreds of popular articles, and thousands of offi- 


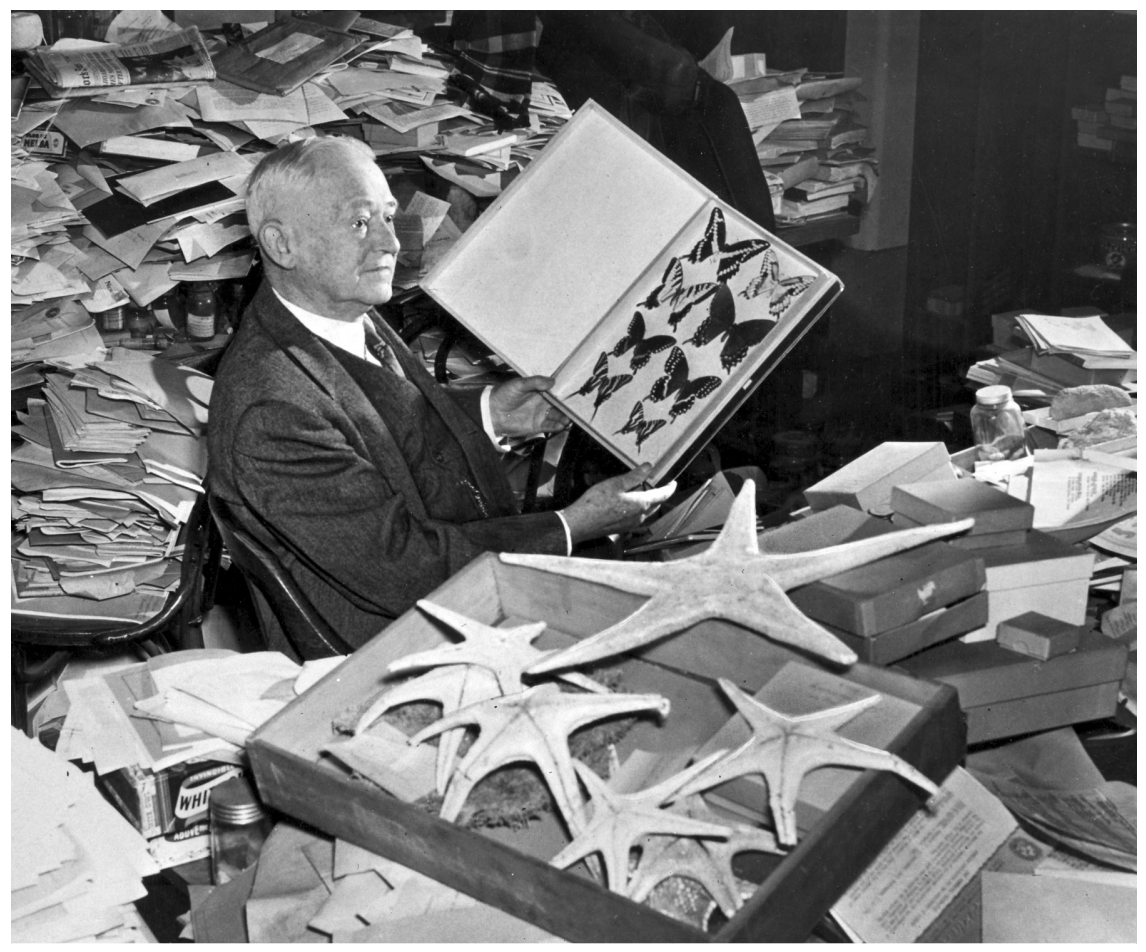

Figure 7.-Austin H. Clark in his notoriously untidy laboratory, ca. 1953. Smithsonian Archives.

cial and personal letters to friends and colleagues around the world (Fig. 7). He was also a pioneer of science programs on the radio and on television (LaFollette, 2008). A short summary of Clark's life can be found in Pawson and Vance (2010).

\section{The Albatross and Its Connection with the Smithsonian Institution}

The Albatross was the first ship specially built for deep-sea marine research (Rathbun, 1892; Hedgpeth, 1945; Allard, 1978, 1999; Spencer, 2002). The vessel was the brainchild of Spencer F. Baird (Rivinus and Youssef, 1992), the second Secretary of the Smithsonian Institution, and also, at the same time, the U.S. Commissioner of Fish and Fisheries. Baird applied to the U.S. Congress for funds for construction of the ship. The Albatross was launched in August 1882 and began its long career in marine research early in 1883 . Specifications of the vessel are provided in several publications (Hedgpeth, 1945). The Albatross was decommissioned in 1921
(Townsend, 1925). A large proportion of the great mass of animals collected by the Albatross reside in the collections of the Smithsonian's National Museum of Natural History where for many animal groups they comprise upwards of $40 \%$ of specimens in the collections. Approximately a dozen Smithsonian scientists sailed on the Albatross over the years.

\section{Albatross 1906 Cruise Instructions}

"In May, the Albatross was dispatched upon an extended cruise in the northwestern Pacific and Bering Sea (Fig. 8) to make certain investigations in the interests of the salmon fisheries of Alaska and the general questions of geographic distribution of Pacific fishes and the relations of the faunas of Alaskan and Japanese waters....." (Bowers, 1906). In a superb publication, mainly about Charles Henry Gilbert, Dunn (1996b) also described some aspects the 1906 cruise-its purposes, its scientific complement, its itinerary, and its achievements. In a publication on birds that he collected, Austin Clark (1910) provided some further details of the cruise, especially sites where he was able to go ashore.

In addition, the U.S. War Department was interested in "gathering military intelligence about the recent conflict [1904-05 Russo-Japanese War]... the military intelligence community was desperate to find out just how strong the Japanese naval capability was and where they were strategically located in the Far East." (Unpubl. anonymous reviewer's comments, 2018). Also see Jennings (1997).

\section{The San Francisco Earthquake}

On 17 April, Austin and Mary Clark moved to a hotel in San Francisco to facilitate access to the Albatross, which was due to sail on 18 April. At 5:12 a.m. on 18 April 1906, the great San Francisco earthquake jolted the city awake. The sailing of the Albatross was delayed for 2 weeks, during which time the ship undertook humanitarian work, ferrying people across San Francisco Bay to escape the fires that ravaged the city following the earthquake. The Clarks boarded the Albatross on 20 April and, before the ship eventually sailed on 3 May, Mary Clark went ashore and made her way back to Boston.

In a letter to his mother on 23 April, Clark described some of the earthquake's effects, and he noted that he and Mary had retrieved their steamer trunk from the basement of their hotel, and dragged it to the home of Reverend Joseph Worcester with whom they spent a night or two. Worcester was a Swedenborgian minister (Kostura, 1997), a sometime architect, and a cousin of Clark's father. On 22 April, Clark and his wife retrieved a bundle of belongings from the steamer trunk and conveyed them to the ship.

Clark noted (A. H. Clark in bio.) that, following the earthquake "I helped remove as many of the collections as possible from the California Academy of Sciences (CAS). These were taken to the home of reverend Joseph Worcester, a cousin of my father's, on Russian Hill, one of the 


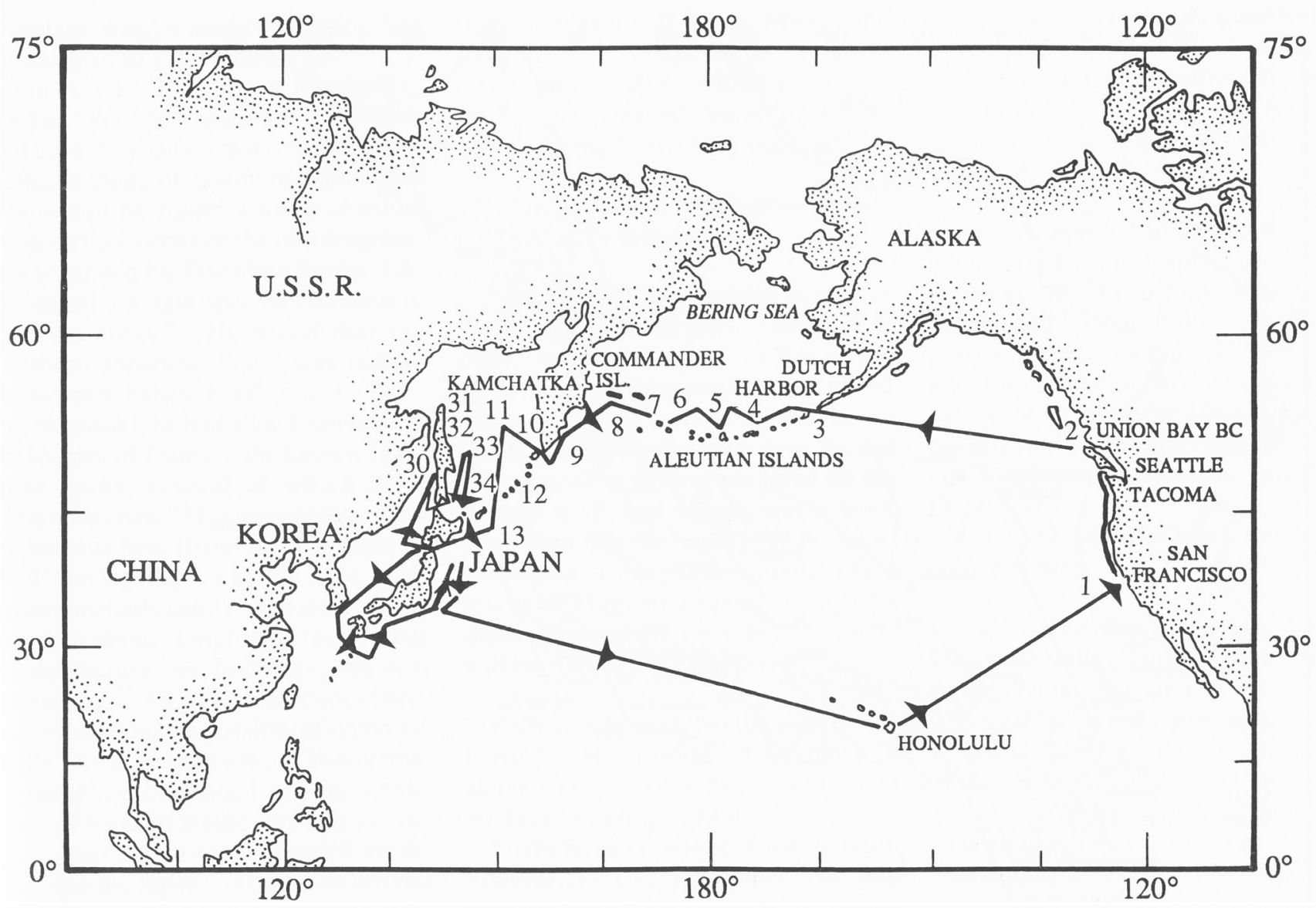

Figure 8.-Route map of 1906 cruise, from Dunn (1996b) with permission.

three houses in this area that escaped the fire."

While we could find no other mention of Clark's involvement in helping to rescue collections from the wreckage of the CAS, Anonymous (1906:825), quoted from a letter written by Miss Alice Eastwood on 7 May 1906, in which she said that she had moved what she could save from the CAS collections to her house and then "the fire was threatening from two directions and I decided to move the 'academy' to Russian Hill that evening. With the help of friends this was done. ...". Indeed, it seems likely that some collections had been stored at Reverend Winchester's house, and that Clark assisted in this move. Leviton and Aldrich (1997), Leviton et al. (2006), and Williams (2007), list the names of a few CAS staff members who were helping to rescue some collections as the fire approached, but no nonstaff members were named.

\section{Some Officers on the 1906 Albatross Cruise (from A. H. Clark in ms):}

Lieutenant-Commander LeRoy Mason Garrett, U.S. Navy (1857-1906) (Fig. 9) had a long service record with the Albatross (October 1904November 1906). Of Captain Garrett Clark noted: "Nothing but good feelings to the end, and so cordial were our relations throughout" (A. H. Clark, in $m s$ ).

Lieutenant Arthur Japy Hepburn (1877-1964) (Fig. 10), was the executive officer and navigator, and also second in command.

Dr. Frank E. McCullough, the surgeon.

\section{Some Crew Members on the 1906 Albatross Cruise (from A. H. Clark in ms):}

About 100 men: well fitted for the work, enlisted in the U.S. Navy, but by no means the typical sailors of a manof-war. The crew was chosen quite regardless of anything but their availability and their being well versed in the handling of sails, in making of nets, and in all the minor arts of seamanship.

F. M. Chamberlain (Jennings, 1987).

Frederick R. Hazard: raised to Chief Boatswain before the fire in San Francisco and lost all his uniforms to the fire.

L. M. Tongue: captain's clerk, paymaster.

Charles Crater: in a Clark letter of Sept. 4: "Crater always acts like an overgrown kid when he gets ashore" 


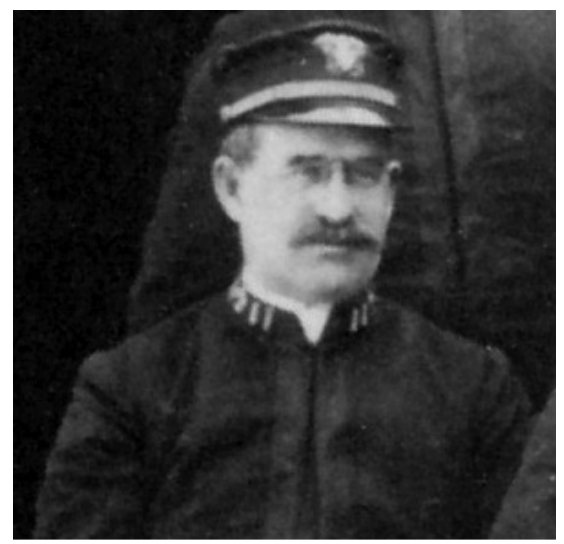

Figure 9.-Lieutenant Commander Leroy M. Garrett, lost overboard 24 November 1906. U.S. National Archives.

with description of his behavior on shore at Yokohama.

O. D. Prine.

Larsen: chief quartermaster (on ship for 24 years).

Bowolski: a Pole who steers the launch.

Alvine: a Swede who sometimes steers the launch.

Hanson: a Swede, raised from seaman to carpenter's mate; my man in the lab, a fine net-maker.

Jacobson: a Norwegian

Valdemar Arnkil: a Finn; raised from carpenter's mate to blacksmith; ship's "writer."

Oskevich: a Russian.

Frederick W. Metters: is English, raised from blacksmith to boiler-maker; father is a high officer in the British navy but Metters' love of the drink has made him an outcast.

Hurliby: worked in lab.

Gibbons: washes the bottles and does chores.

Riley: chief master-at-arms (policeman) reduced to fireman because of boozing; ran away at Nagasaki.

Devine: ran away at Nagasaki.

Baldwin: hospital steward.

A Greek.

1 or 2 Germans.

A machinist from Rotterdam, in Holland.

2 Boatswains and a Warrant Machinist.

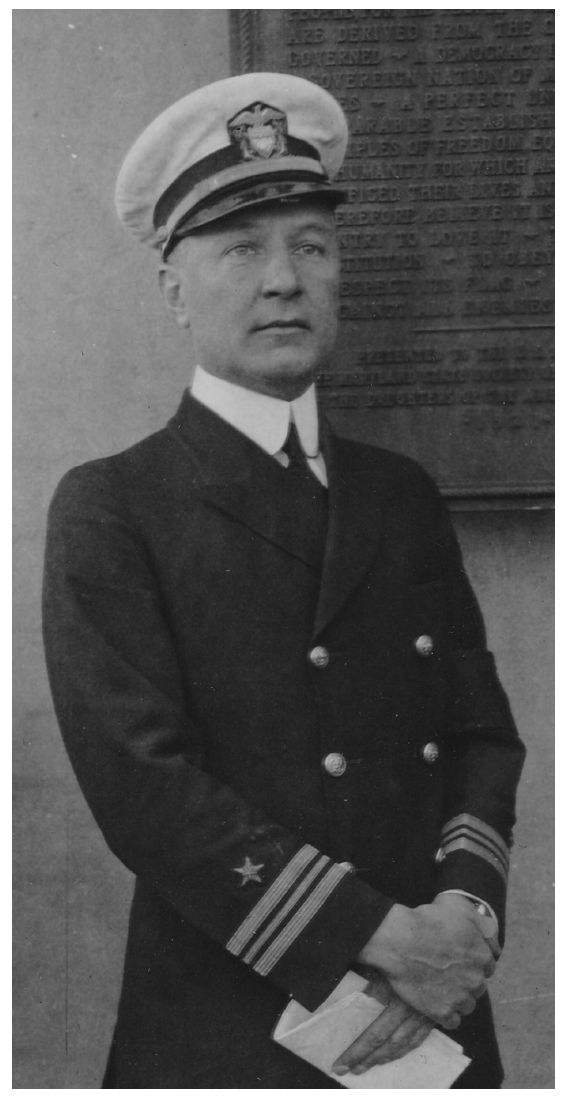

Figure 10.-Lieutenant Commander Arthur J. Hepburn, assumed command of the Albatross after the loss of Lieutenant Commander Garrett. U.S. National Archives.

\section{Scientific Complement, Albatross Cruise 1906 \\ (from A. H. Clark in ms, and Hedgpeth (1945):}

Charles H. Gilbert (Fig. 11) chief naturalist and ichthyologist, "was strongly devoted to his work and possessed a demanding personality" (Dunn, 1996b). He had a history of being antagonistic towards the captain of the previous cruise (Dunn, 1996a) to the extent that Captain Chauncey Thomas requested a transfer. Thomas said "I trust the Commission will see that he [Gilbert] is not a fit person to be placed in contact with gentlemen under any circumstance." Thomas had also written that Gilbert needed a strong hand to manage him (Dunn, 1996a). In his letters, Clark

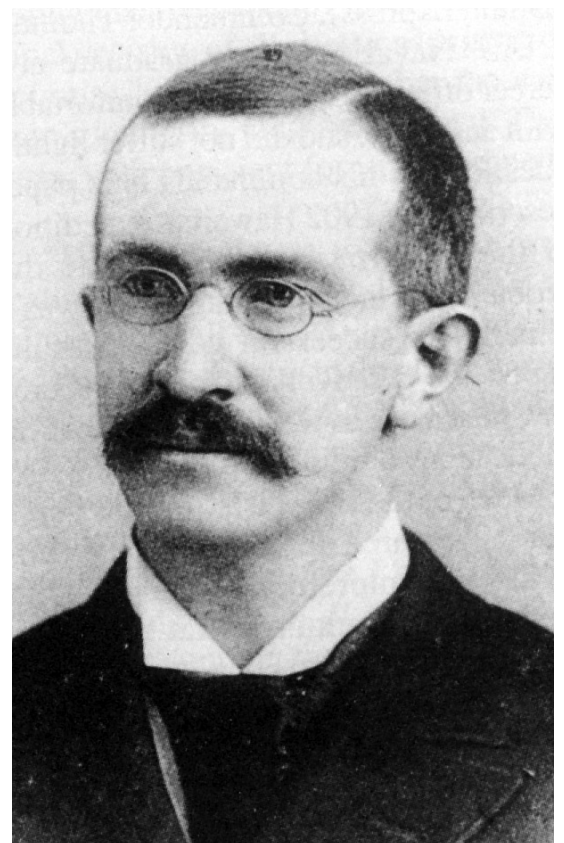

Figure 11.-Charles H. Gilbert, Naturalist-in-Charge, ca. 1906. Stanford University Archives.

cited several incidents where Gilbert was "brought down a peg" by Captain Garrett or "squelched," or "put in his place" and was always "very secretive" about his plans. Gilbert participated in seven Albatross cruises, and he had a distinguished career as a Professor at Stanford University (Jordan, 1928; Brittan, 1997).

Austin H. Clark: Chief naturalist.

John Otterbein Snyder: became professor at Stanford University (Fig. 12) (Biographies at Brittan and Jennings (2008) and at https://web.archive.org/ web/20060901074405/http://wwwmarine.stanford.edu/HMSweb/Memorial\%20Resolutions/SnyderJ.pdf).

Harold Heath: became professor at Stanford University (Fig. 13) (Biography at http://athopkins.stanford.edu/ HeathH.pdf).

Charles Victor Burke; one of Gilbert's graduate students. See Charles Victor Burke Cruise of the Albatross, diary and journal, Stanford University Archives SC0457.

Michitaro Sindo: Japanese student at Stanford University, 1900-1906. 




Figure 12.-John O. Snyder. Stanford University Archives.



Figure 13.--Harold Heath. Harold A. Miller Library, Hopkins Marine Station.

- Tanner-Blake sounding machine

- Wing-nets (butterflies)

Buck, the ship's mascot (in part from Clark in ms.; Clark letters):

Buck (Fig. 17, 18) was one of 12 young goats presented to the Albatross in 1899 (chief scientist Alexander Agassiz) by a chief on the Marquesas Islands (Hedgpeth, 1945). The ship's crew ate 10 of the goats, one was washed overboard, and the sole survivor, Buck, ruled the ship for at least 12 years. Hedgpeth (1945) referred to the goat as "Old Bill," and he noted "As the gift of a foreign sovereign, the goat was sacrosanct and its health a matter of official concern, and he made the best of his exalted station in life." Somehow, by 1906, the goat's name had changed to "Buck."

(From A. H. Clark in ms.): "Our mascot on the ship was a large goat with enormous horns called Buck. On occasion he can exhibit a well developed sense of humor. At high tide he was induced to leave the ship to frolic on the dock with some of the sailors who thoughtlessly, or perhaps intentionally, left him there when they returned for lunch. At low tide in the

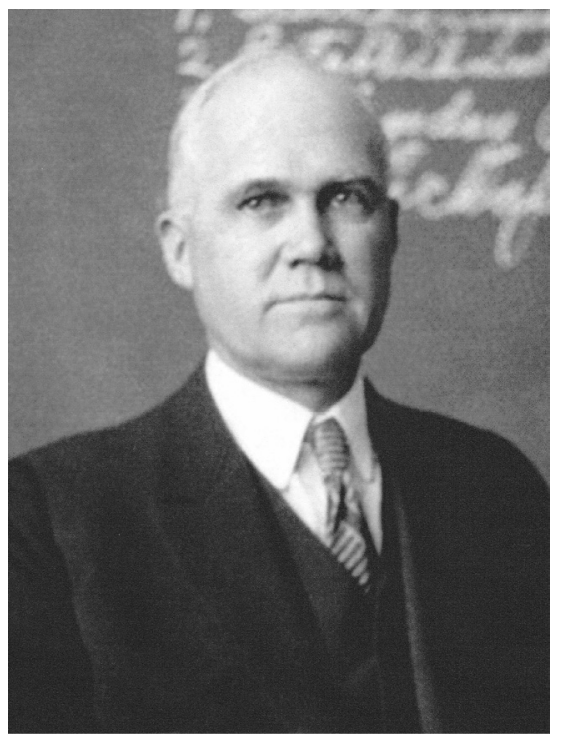

Figure 14.-Harry B. Torrey. Marine Biological Laboratory Archives and Embryo project, Arizona State University.

afternoon his best friend the Chief Quartermaster discovered him looking sadly down upon the ship from a position about ten feet higher than the upper deck. Moved by pity for his plight, the quartermaster went ashore and procured a number of long boards with which he made a double incline leading from the wharf to the base of the smokestack, and thence to the deck. This was a difficult and arduous piece of work, for the quartermaster, though a first class sailor, is neither a first class engineer nor a first class carpenter. True, the other sailors were very generous in offering him advice, but in general this advice was not of such a nature as to assist the work materially. Buck surveyed the incline in a haughtily and supercilious manner, and positively refused to trust himself upon it. The eloquent pleading of the quartermaster, seconded by the other men, and the offer of all sorts of tempting delicacies, were alike without avail. Suddenly, and quite without warning, he leaped wildly into the air, descended upon the deck, and hurriedly scuttled forward to the great delight of the crew and the great chagrin of the quartermaster. 


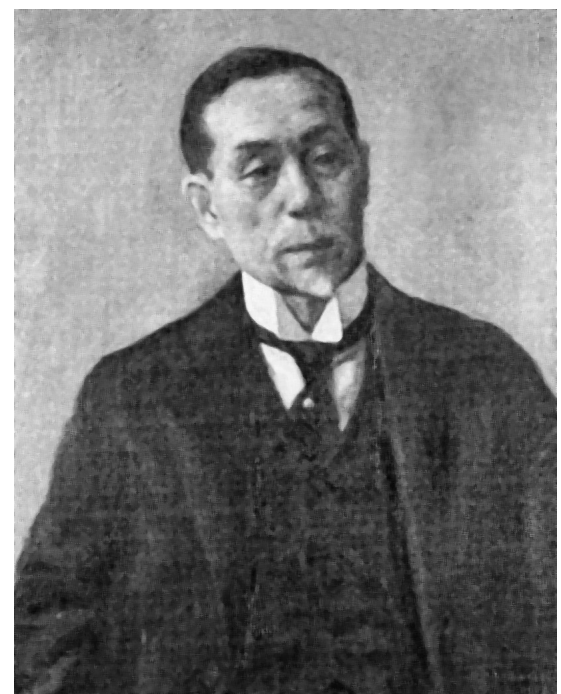

Figure 15.- Seitaro Goto. Smithsonian Archives.

Word was passed around not to feed Buck with any more toilet paper. His consumption of that article is something stupendous. Copper nails are also under the ban, as when taken in large quantities they made him ill. His diet is now confined to tomato cans, newspaper, rubber scraps, cloth, etc., besides potato peel and other staples.

Buck squared accounts with one of the cabin boys who had teased him. He caught him squarely from behind as he was juggling a tray of food along a slippery and reeling deck.

One day the engineer decided to go ashore on an extensive shopping tour. He drew a rather large sum of money in the local money and while waiting for the launch, amused himself by teasing Buck, the goat. He would present a bill to him and as he reached for it, draw it away quickly. Suddenly the captain stepped from the cabin and called his name. As he turned and saluted he crammed the bills hurriedly into his trouser pockets. Unfortunately his jacket caught on them. This gave Buck the opportunity. Approaching quietly from the rear he skillfully removed bill after bill eating them with the keenest satisfaction. In the short space of time occupied by the conversation between

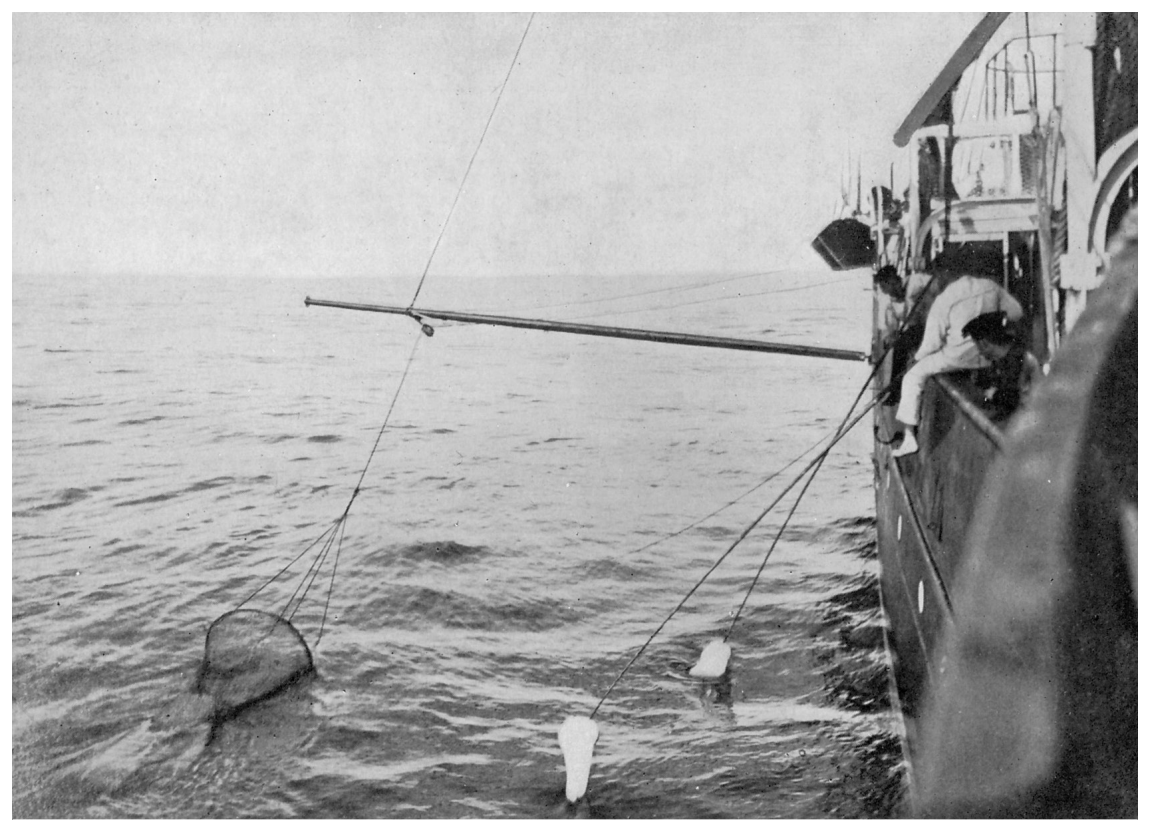

Figure 16.-Various methods of surface and near-surface fishing from Albatross. U.S. National Archives.

the engineer and the captain, Buck managed to get away with about \$100!!" (Buck was still alive and well in 1911, when a young Dr. Henry B. Bigelow was on board the Albatross (Fig. 17).

\section{Coaling (from A. H. Clark in ms.)}

From Seattle we went to Union Bay, Vancouver Island [B.C., Canada], to replenish our supply of coal. By a grotesque anomaly the word "coaling" sounds rather pleasing to the ear, but the actual process can only be described as a sort of recurrent martyrdom inflicted upon all those forming part of the personnel of steamers. Life on a ship when coaling is anything but pleasant. Coal dust lies thickly over everything and flavors all the food. It enters every room and may be found even in the remotest portions of the wardrobe drawers. I even found the birds in this vicinity to be affected by it, for some which I secured in the vicinity of the dock were unusually dark in color, and on examination this darkness proved to have its origin in quantities of coal dust introduced between the feathers.

\section{Some Destinations on the 1906 Cruise}

The destinations below are extracted from Clark's letters and from Clark (1910). This list complements the list provided by Dunn (1996b), which latter is restricted to approximate locations and dates upon which dredging took place.

- May 3: After two weeks' delay caused by the San Francisco earthquake, underway at 4:40 p.m.

- May 8: Off Columbia River going along coast, up Puget Sound, and though Juan de Fuca Straits.

- May 9: Tacoma, Washington. Dockton on Quartermaster Harbor near Tacoma, ship dry docked to be cleaned and fitted.

- May 11: Puget Sound Navy Yard at Bremerton, Washington.

- May 12: Seattle.

- May 14: Comox, Union Bay, B.C. for coaling.

- May 17: Anchored at Forward Bay, Johnstone Strait, near the northern end of Vancouver Island.

- May 19: Through Goletas Channel and Unalga Pass. 


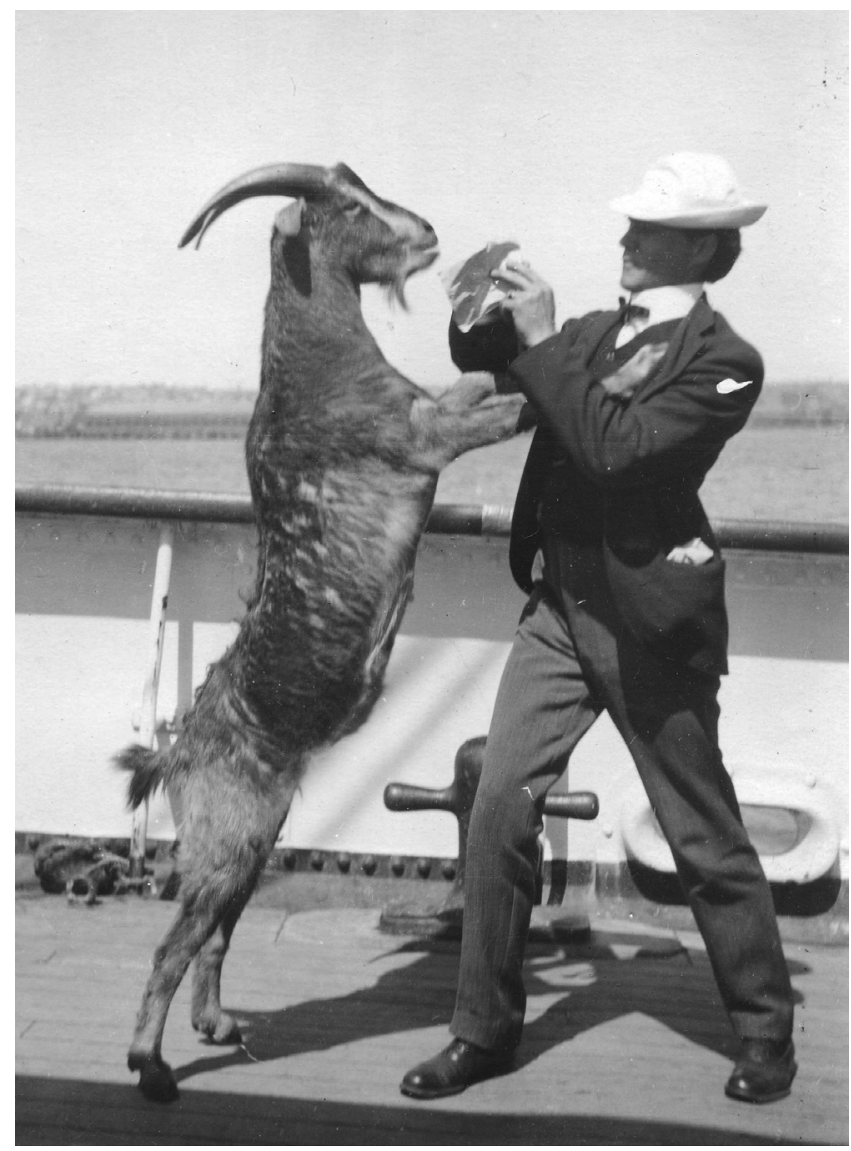

Figure 17.-Buck the goat, with Dr. Henry B. Bigelow, 1911. Scripps Institution of Oceanography Archives.

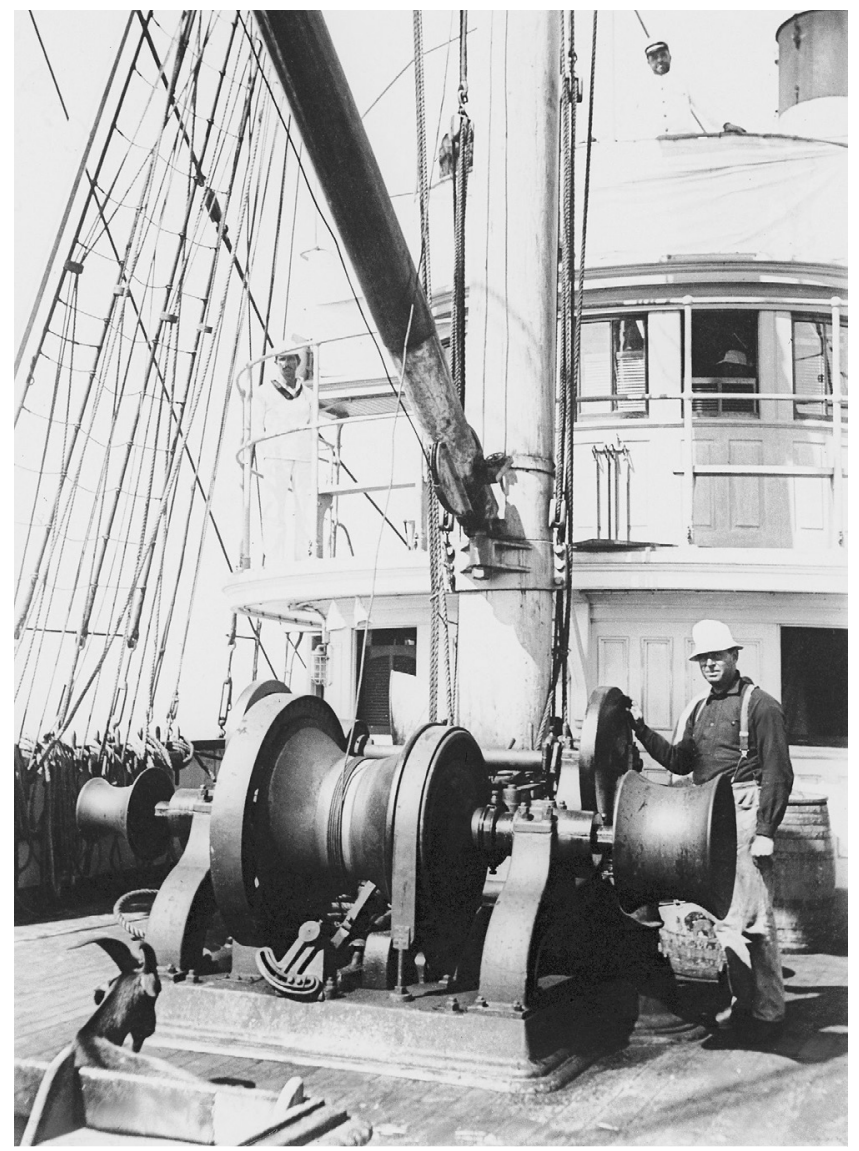

Figure 18.-Trawling winch on Albatross, with Buck the goat (lower left) looking on. U.S. National Archives.
- May 23: Pt. Farewell, Shumagin Ids.

- May 24: east Ugamak Id.

- May 28: Bogoslof Ids.

- May 29: Yunaska Id.

- May 30: Nazan Bay, Alaska, Atka Id.

- May 31: Koniuja Id.

- June 1-3: Bowers Bank, Bering Sea.

- June 5: Petrel Bank, Bering Sea.

- June 7: Anchored at McDonald Bay, Agattu Id, Aleutians, via passage east of Semisopochnoi and Amchika Ids.

- June 9: Anchored at Chichagof Harbor, Attu Id. via Semichi Ids., Aleutians.

- June 13: Around eastern end and south of Attu Id. to Preobrazhenie Bay, Medni (or Copper) Id.

- June 14: North Point, Copper Id.
- June 17: Petropavlovsk, Avatcha Bay, Kamchatka.

- June 21: On Codfish Banks, off mouth of Aangan River, west coast of Kamchatka.

- June 23: Milne Bay, Simushir Id, Kuril Ids.

- June 27: Hakodate.

- July 5-7 Mororan Harbor.

- July 18: North Point, Sado Id.

- July 21-23: Nanao, Noto Peninsula, Hondo.

- July 23 To Tsuruga, Hondo.

- July 24-25: From Tsuruga, Hondo to Saigo, Dogo Id. Ki Group (Sea of Japan).

- July 25: Saigo Maki (Dogo Island) (shore collecting).

- July 28: Anchor at Matsushima.

- July 30: From Matsushima to Nagasaki, Japan.

- August 3-4: Nagasaki.
- August 11-14: The northern Linschotens.

- August 16: From Kagoshima to Kobe via Bungo Channel and Inland Sea.

- August 17-19: Kagoshima.

- August 26: Kobe.

- Sept 19: To Otaru, Hokkaido via Tsugaru Strait.

- September 20-24: From Otaru to Korsakov, Aniwa Bay, Sakhalin Id., via Gulf of Tartary and La Perouse Strait.

- October 4-8: Hakodate.

- October 9: Town on the Shima peninsula in the Gulf of Sendai.

- October 12: In Suruga Bay.

- October 17: Off entrance of Suruga Gulf.

- October 23: In Sagami Bay.

- October 26: In Uraga Strait (entrance Gulf of Toyko). 


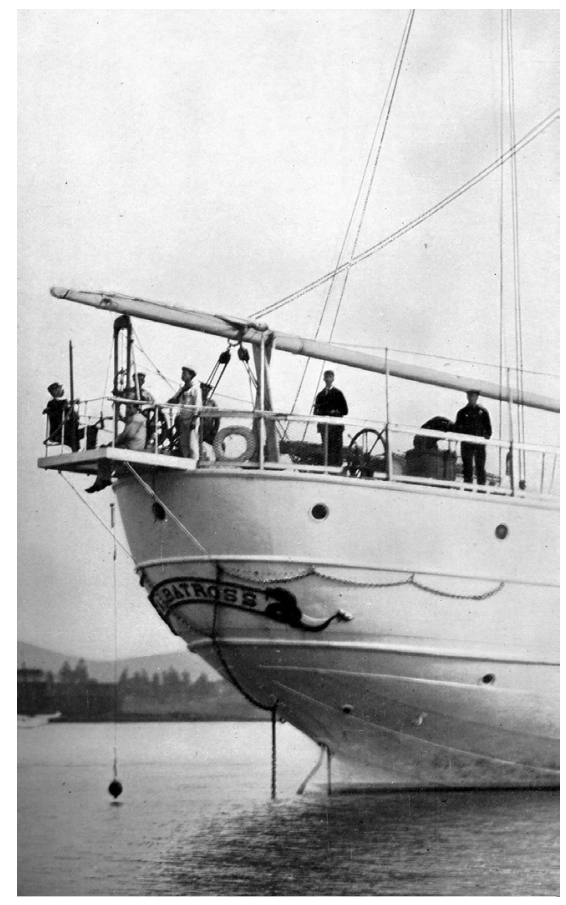

Figure 19.-Poop deck ("afterdeck") of the Albatross, showing starboard railing, through or over which Lieutenant-Commander Garrett was thrown to his death. U.S. National Archives.

- November 10: Homeward bound from Yokohama.

- November 24: Arrive in Honolulu.

- December 2: Left for San Francisco.

- December 10: Arrive in San Francisco.

\section{Political Situation in Japan and} Russia-Restricted Access to Sea of Japan

Dunn (1996b) summarizes the political situation following the Russo-Japanese War of 1904-05. Of great importance to operations of the Albatross in 1906 was the fact that martial law was still in effect, access to the Sea of Japan was severely restricted, and there was danger from hundreds of floating mines.

\section{Captain Garrett is Lost Overboard, 21 November 1906}

Dunn (1996b) summarizes the loss overboard of Captain Leroy Garrett,

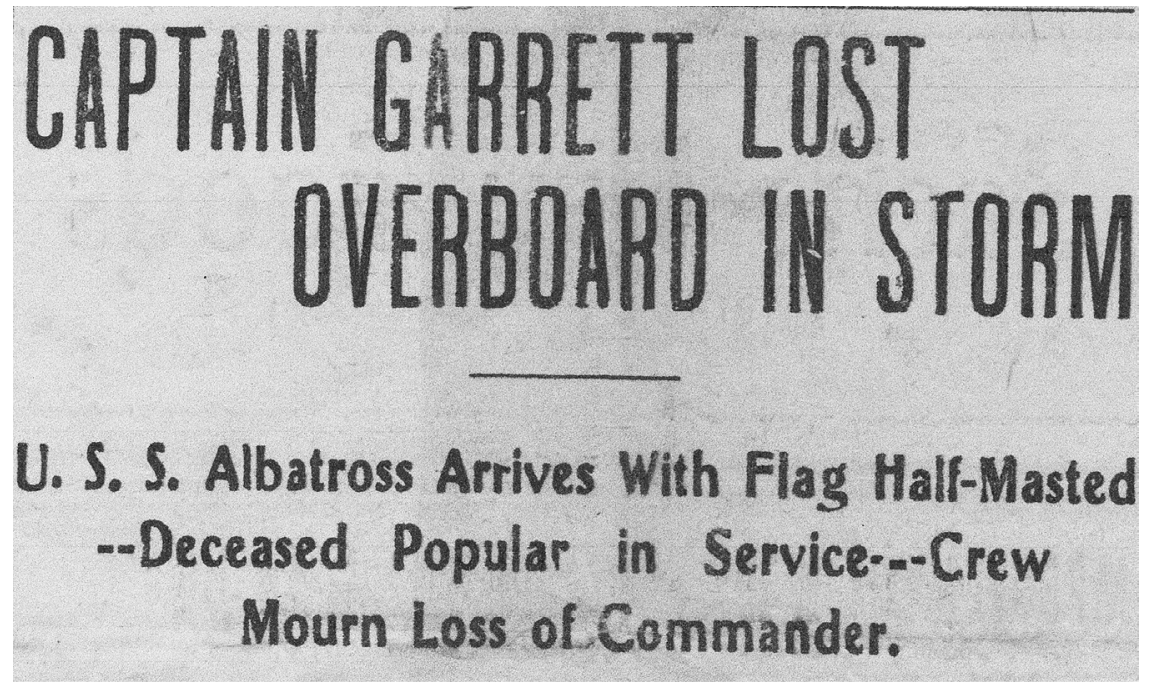

Figure 20.-Headline from Sunday Advertiser, Honolulu, 25 November 1906. U.S. National Archives.

and the ensuing formal inquests. Clark reported the incident as follows:

"November 21. Today has been a sad day for all on board. The captain fell overboard and was lost at half past seven this evening. It had been a fine day today, fairly smooth sea and a fine breeze on the port beam, and we had all sails set and were making 11 knots and over which is doing very well for this boat. The day had been absolutely uneventful; the table had just been cleared and all the chairs were lashed to it to prevent their moving about. I was standing at the starboard (leeward) end of the wardroom table talking to Mr. Hepburn and Mr. Snyder who was sitting on the transom in front of me, about marine engines when we heard a cry. It was faint and indistinct, but we all stopped talking and Mr. Hepburn said "What's that?" Immediately after we heard the paymaster, who was on duty, cry "Man overboard!" We rushed up on deck. They were taking in the big mainsail and the other sails forward, and was putting the ship about to go back to hunt for the lost man. I gave a hand to the ropers to help the men with the sails and when that was done, Mr. Hepburn called a muster of the crew to find out who was missing. We had seen practically everybody at the ropes and was begin- ning to think it might be a mistake. After that $\mathrm{Mr}$. H. called for the muster of the officers and then we realized that nobody had seen the captain. Mr. H., the doctor and I went into the cabin, but he wasn't there and then somebody discovered that the netting that runs around the poop just under the rail was carried away in one place between two stanchions (the uprights which hold the rail) and a steamer chair with a couple of legs broken was right side of it. Apparently he was sitting in the chair on the windward side and when the ship gave a lurch the chair had slid clear across the deck and shot him off through the wire netting (Fig. 19, 20) into the sea. The first cry we heard was probably his as he fell into the water. A life buoy was thrown as soon as it was realized a man was overboard, but it would have been practically impossible for him to have found it in the dark. We got back to the place as soon as we could and have been playing the search light about ever since in the hopes of picking him up; but it is nearly one now and he could hardly have kept himself up so long especially as he had all his clothes on.

"November 22. We drifted and sailed slowly back and forth all last night until 6:30 this morning, trying to find the captain, but it was no use, 
so at 6:30 we got under way again for Honolulu."

\section{Lt. Hepburn Assumes Command of the Albatross}

After the loss of Captain Garrett on November 21, Lieutenant Arthur Japy Hepburn (1877-1964) took command of the Albatross for the remainder of the 1906 cruise. In later years, Hepburn rose to become an Admiral and Commander of the United States Fleet. See biography at https://en.wikipedia. org/wiki/Arthur_Japy_Hepburn.

Achievements of the 1906 Albatross Cruise

Dunn (1996b) provides details of the achievements of the cruise. Suf- fice to say here that the ship occupied 339 dredging stations and 48 hydrographic stations. In addition, numerous shore collections were made, especially of birds (Clark, 1910), and additional animals and plants were collected by surface nets and line fishing. In terms of scientific information gathered, the cruise was regarded as very successful.

\section{"Editing" of Clark Letters-Policy and Procedures}

In the course of transcribing Austin Clark's letters from the Albatross, we noted occasional derogatory comments about the culture and habits of the various peoples encountered during the cruise of 1906 . There were also numerous terms of endearment em- ployed by Clark in letters to his wife. We were inclined to delete these comments and terms of endearment but, before doing so, we sought the advice of two experts, noted historians Drs. Marcel Chotkowski LaFollette and Kathleen W. Dorman. Both strongly recommended that we retain the original text, and Dr. Dorman cited Kline (1987, p. 106) "These intimate records, which can reveal so much of the inner life of a public figure, demand the most literal textual treatment their method of inscription permits" (Fig. 21). 
POST OFFICE ADDRESS

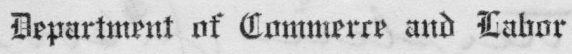

BUREAU OF FISHERIES

Stranter Allratrogats

Wutch Hearbor Mnalacka nay 25, 1906 .

Vleans6, deaus inj

m lean eavly tomonow monining

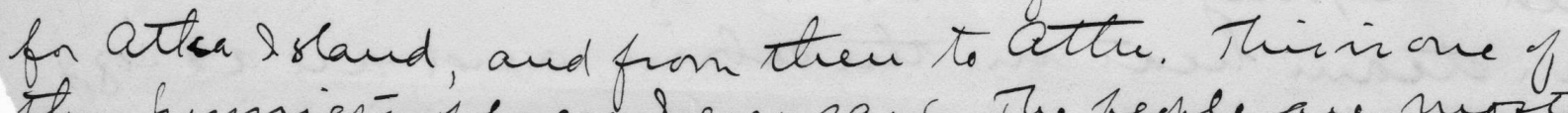
th fumiest pecer sem saw. The feople ane mosty Andianr, mith Russiaur and some Omericans. Then is a Russian chuch at Mnalaslca, and a gan yand mith Russian names on the tonbstover. Th tombstomer ace all q wood in th shape f-a Rusicin cers, like thi $\neq$. Clater and recut huntringfitarmigan today on a lays mountain hhin hlutch Heabon. In thoi5, and sane the hids. An had a haid dog gin. The ground was ny stup, and in many fla us the suar war up ta on raiste. Dt rae soming heavily mos of the tive. Mll, deanes min, the fise stagr of the joimeg in on, and $m$ byin the second staps tomonor. Somelow, on leans hen, lsor of ful as it it noued uibh solong hfon 0 su you aganin, dean liteh surtetheari. In are going to Petropanlolin, Kanchatea, ina Otca, attw, ang Agattu dslands. The mather ingreat now, and the sea in mice and calm, so lexve ct m shall ban a good thip. bought a citi litilo pain foliffers jes

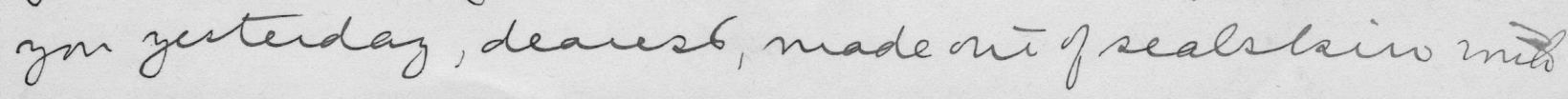

Figure 21.-Example of the handwriting of Austin H. Clark in letters to his wife Mary. Smithsonian Archives.

$80(4)$

13 


\section{Letters from Austin H. Clark to his Wife Mary from the Albatross, 3 May to 1 December 1906}

\section{Letters from Clark to his Father 15 May, 12 September, and 24 November and to his Mother 4 September and 24 November}

May 3. Started from Sausalito, Cal. At 4:30, leaving S.F. bay by north passage. Weather outside rather heavy, but no wind. Had on board, besides men you met, Dr. John O. Snyder (Leland Stanford), Mr. Burke (Student, Leland Stanford) and a Jap, Mr. Sindo, also student there. Dr. Torrey came aboard in the morning at Sausalito and brought some things; he will join us with Dr. Gilbert at Comox, Vancouver Island. The sea was moderate and all took supper together (Fig. 22). Crater got stuck for beers (I, not indulging). Next run at the table is Dr. Snyder, and on the other side Mr. Sindo (the Jap). Dr. Snyder in between me and Mr. Hepburn.

May 4. At breakfast, only Crater, Mr. Hepburn, the 3 bosuns, and myself visible. Dr. Snyder appeared later, and stayed long enough to eat $1 / 4$ of an apple, and Dr. Mc Collough joined us later. Tongue, Sindo, and Burke, and the Paymaster remained dead to the world. Used a tow net at 10 a.m., and got lots of funny shrimps and bugs of all kinds, and 5 minute fishes. Spent day sorting out catch, Dr. Snyder helping for short intervals, alternating with long periods spent in repose in his cabin; he finally subsided altogether. Sea got rougher by P.M. and still rougher at dark. Lots of albatrosses followed ship all day, perhaps attracted by name.

May 5. Gehosophat! What a night: sea was rougher than ever, and a great old gale sprung up. Everything got loose in my cabin and in the lab. and had to be captured and tied up; also a warm wave came through my window. About 5 a.m. a big wave came over the bow, and soaked the officers on the bridge. Rolled and pitched about like fun all day. Mr. Hepburn feeling shakey. The 3 bosuns, Crater, Mr. Hepburn, the doctor and I the only ones at meals. Tongue and I tried to play chess after lunch: 1st game ended by the chess board and I landed in a heap on the transom (the window seat affair at the side of the ward room). I got licked the second game. 3rd game I lit on the floor, with the chess outfit all over me. Waves kept coming all over the decks, water being sometimes 4 inches deep in front of the captain's cabin, swishing about in great style. A lot of water splashed into the ward room through the skylight. Prine got soaked through by a big wave just as he was coming down from the bridge. Metters lost his best uniform cap (a brand new one) overboard. All the cabin boys and cooks, and some of the sailors are sick. Poor Mow a piteous object, but still game. After lunch

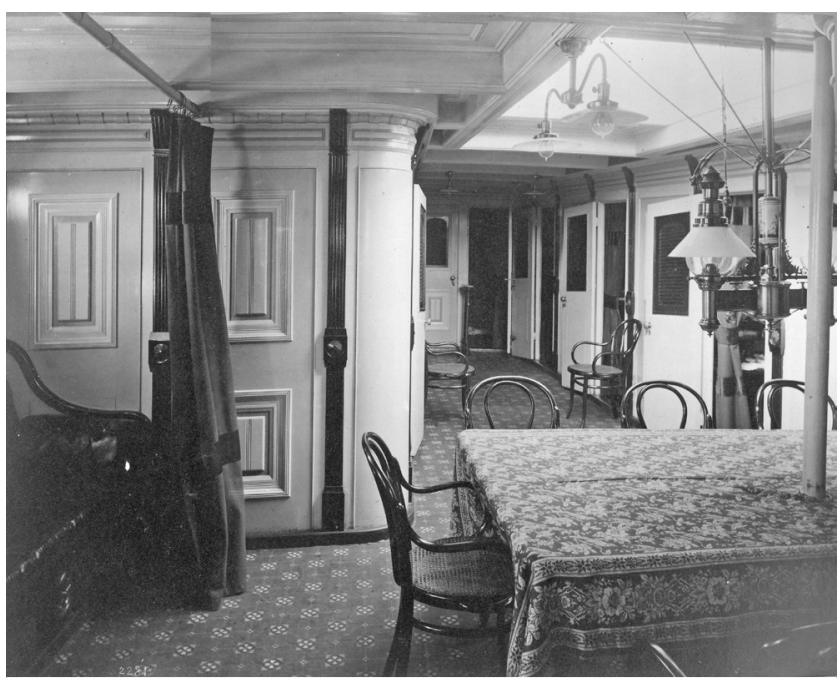

Figure 22.-Wardroom on Albatross, note table, electric lights. U.S. National Archives.

Metters entertained the Paymaster with selections on the piano; such as "Home Sweet Home' and "Nearer my God to Thee". The paymaster could only groan a response. Have been making about 3 miles an hour all day, and are wondering how long it will take to reach Tacoma at this present rate of progress. The wind and the sea are dead ahead. Standing near the stern, the sea is just about 30 feet below, with both propellors visible, then the water comes up clean to the little platform. Once in a while the bow sprit goes clean under, and the ship rolls so as to take in water over the rails on each side. Captain very genial and pleasant. Barrel of pickled pigs' feet stored on the forward deck got loose and broke to bits. Sailors swiped entire contents. The barrel was part of the paymaster's stores, but he is far beyond caring for little details now.

May 6. The sea was much smoother today, resulting in much better representation at the breakfast table; in fact all but Mr. Burke was surprised to discover that it was Sunday, Mr. Prine and Mr. Metters discarded their uniforms and appeared in ordinary clothes, looking more or less like pirates. During the a.m. the skipper showed up in a brown suit sweater, and brown sombrero, looking like an old hayseed. Nothing much happened all day. There were lots of whales around all the p.m., 9 being in sight at once, 2 of them right side of the boat, about $20 \mathrm{ft}$. away. They made a great noise blowing. We made better time today, reaching a speed of almost 5 knots an hour sometimes. Everybody feeling better.

May 7. Sea smoother still, with less wind: warm and summery: have been in sight of the Oregon coast all day. Lots of whales and dolphins around. The paymaster donned 
a brown suit and black sombrero. Everybody has revived, although Mr. Burke still feels a bit shaky and doesn't eat much. Mr. Hepburn and the doctor visibly improved by the smooth sea. The paymaster has been around all day for the first time, and can actually eat. Crater blossomed out in ordinary clothes, with a blue flannel shirt. The forests along the coast have all been burned over, and present a most desolate aspect of dead trees on a brown background. Passed a lighthouse and small village this P.M.: boat making much better time. Beautiful moonlight tonight and ship almost as steady as in S.F. bay.

May 8. Sea very smooth: breeze very light in morning, but freshened up in the afternoon. We were off the mouth of the Columbia River at 8 this morning; the water there was muddy, like S.F. bay. We were in sight of the coast all day: it was usually rocky and wooded, but with great stretches of sandy beach and a few dunes. Passed close to the lightship at about 8:30. In the afternoon we saw great snow mountains back from the seacoast: they looked very pretty. Everybody wore ordinary clothes today. Metters got crusty because the doctor reminded him it was against the rules to smoke in the wardroom at sea, especially as it was very nauseous to the people just recovering from "mal-de-mer." Metters refused to stop. The doctor was arguing on behalf of the paymaster, to whom tobacco smoke at present means misery, but it was no use. Everybody was at the table today. This evening playing "highfives" the doctor and the paymaster had a difference of opinions as to whether the latter held too many cards in his hand or not. Word was passed around not to feed Buck with any more T.P. [toilet paper], as his consumption of that article is something stupendous. Copper nails, also under the ban, as when taken in large quantities they make him ill. His dieting now confined to tomato cans, newspaper, rubber scraps, cloth, etc., besides potato peel and other staples.

\section{Tacoma, Wash.}

\section{May 9, 1906}

\section{Dearest dearest wife,}

We have just reached Tacoma, about a day later than expected. The mail orderly went ashore as soon as we got here and brought 4 letters from you. I never was so glad to get anything in all my life, dearest. I never felt so lonesome and homesick as I did coming here, but I am going to try and be brave darling, and to keep looking forward all the time. I never quite realized how much I do love you, Mary, before. I think it is a good scheme, dear to only write cheerful things in our letters, and I will do it, too. I didn't know that I could be so lonely and homesick as I have been dearest. We had just lovely weather coming up Puget Sound, and through Juan de Fuca Straits, just as smooth as it could be, and nice and warm. We passed Seattle on our way up. I am going to keep a diary every day, dearest, like the one I send with this, so you can always know what is happening. I am so glad you had a chance to stay on the ship for a while, dear, because you can understand what I say in the diary about the officers, because you know them and know all about the ship, dearest. It was awfully funny yesterday. I was putting $36,000 \mathrm{ft}$. of sounding wire on the machine. It is piano wire of the best quality and expensive, and comes in lengths of 6,000 ft, so the lengths have to be spliced together. I made a splice, with the help of Teed and Mr. Crater, and just then the skipper came up, and I showed it to him: just as I took it up off the deck to show him, it broke right in the middle. He let out the same exclamation your cousin Wendell did at dinner at the New Willard when Dorothy wanted orange ice, and in the same way, but didn't get mad at all. Poor Crater is feeling sad: on the way up the skipper told him to only use 13 baskets of coal an hour in the boiler, because we were getting short; so he did, and we only made 3 miles an hour in consequence: then the skipper gave him an awful roasting for not using more. This is a dandy boat at sea; it was very rough coming up, but she rode over the waves like a cork, and didn't roll around nearly as much as I had expected she would. We are going to dock now, and then go to the navy yard at Bremerton for some more sailors and then to Seattle for Dr. Gilbert. He is coming here instead of going to Comox. We are going from Comox to Unalaska for coal, and then right to Japan. I am going to take my best care of myself, dearest wife. I am glad you know the officers on the ship, so you can see I will be perfectly safe, as they are a nice reliable set, and have had lots of experience. Prine, Metters, and Hazard all used to be sea captains, and all used to run to Barbados, and we have had great fun; they all claim I am a Barbadian, and jolly me about it at every meal. Metters was the only person on board except myself who wasn't seasick coming up. One of the Jap boys isn't over it yet. The country up here looks just like the coast of Maine; all fir and pine trees. It is very pretty along Puget Sound. Some papers came aboard with the mail, with big headlines "Train wrecked by earthquake." The S.P. express to New Orleans from S.F. was derailed by the earthquake just south of San Jose, and several people were killed. I got rather scared for a minute, dearest, and was awfully relieved to find you had reached Chicago safely. They had several rather bad earthquakes in S.F., which threw down many of the standing walls. I am very glad you are not in Calif. I should be worried to death, dearest. I am glad you found some companions on the train, dear, it must have made it much better for you. Be sure to take awfully good care of yourself, dearest, dearest wife, won't you? I am glad you had supper sent into the car that day, dear; you will be careful, won't you? Give my love to Betty and your mother. I think the best way for me to address you in care of pa, 15 Beacon St:: you can give him your address, and he can forward everything to you, dearest. My address is Hakodate, Japan, as we will get to Unalaska before any mail steamers, as they do not run til summer. I will write to 
you every single day, dearest, dearest Mary, and will send you a letter every day I am in port.

Lots \& lots \& lots of love dearest, and lots of kisses from your loving husband.

Bremerton Navy Yard. Washington

May 11, 1906

Dearest, dearest wife,

We left Tacoma just after I wrote you yesterday, and came up to dry dock in Quartermaster Harbor, where the ship was put into a sort of big wooden tub and the water pumped out. The whole bottom was a mess of barnacles. She looked awfully big out of water; there is a lot more of her below the surface than above. It was funny living on the boat in dry dock. Instead of seeing water when you looked over the rail, you looked way down and saw a wooden floor. You had to get off down a great long ladder. There is a little town called Dockton at the dock where the people who work the dock live. Yesterday afternoon the doctor and I took a long walk through the woods with a couple of guns and shot some birds, which I have been stuffing today: so you see I am beginning my collections already. I have also 4 rats which the sailors caught. We have had a great time with the sailors deserting: last night while we were in the dock 4 ran away, leaving us with 15 less than when we were in S.F. We have come up here to get some more. They have 11 that we can have, and they have telegraphed for more. Do you remember the rather good-looking boy who used to be in the stern of the launch whenever we went ashore? He skipped last night. They will get 2 years in jail if they are caught. Do you remember my writing that the paymaster and the doctor had a row over a card game? The doctor is mad and hasn't spoken a word to the paymaster since. The paymaster told me all he's won today, quite a string of them. He comes from the mountains of Tennessee. The doctor has been to Tennessee and knows he comes from way back in the country, and he says he has taken no pains to conceal his contempt for a person from there. He told me I ought to be able to sign him up, because I had been to his town, and knew the kind of people there: he says his people are poor and hard working and he had got his position through hard work, and now he has got it, he doesn't like to be treated like a common sailor, even though he realizes he does not belong to the upper class. He seems quite worried about it, and I rather pitied him because he is a nice chap. He says he realizes there is a big social gulf between himself and me, but he says I have always treated him as a gentleman should, and the doctor hasn't. He says he can judge a man by his wife, and he said look at the difference between you and Mrs. Hepburn, and Mrs. McCullough. His meeting you, dearest wife, has apparently raised me about 100 degrees in his estimation. Wasn't it funny he should tell me all this? He said before I came out the Fish Commissioner wrote the Captain he was sending out an especially capable man to fill Mr. Chamberlain's and Mr. Fassett's place. Isn't it funny. He told me Metter's father is a very high officer in the British Navy but Metter's love for drink has made him an outcast. He said Metters showed good breeding in spite of his coarse exterior. Metters was telling about some pigs yesterday that he fattened up on a diet of soft coal on a steamer he was on. He said he always fed them that at sea. He used to be a chaplain's assistant and he told us about how he lost the position. Unfortunately, he got rather full one Sunday morning, and when he sat down at the organ, a jig came into his head, and he sort of couldn't help playing it, so he played it through and wound up with a shout and fell off the stool, kicking his feet through a panel in the organ as he went over. Beats tuning the piano, doesn't it? I don't know why I'm writing you all this rot, dearest, dearest wife, but it seems to be all there is to write. We are going away tomorrow to Seattle to get Dr. Gilbert, and going Sunday to Comox. I am anxious to get away from here, because the sooner we go the sooner I shall get back and see my dear little wife, the dearest, noblest little woman in the whole world again. I often think, dearest how brave you were to come ashore with me that day when we got stuck at Sausalito. You were so brave, dearest, dearest Mary, and the more I think of it the more I appreciate what a perfect, ideal little treasure I have got. I shall have a good chance to show on this trip if I am any use, darling, and I shall try my best to be worthy of my dear, dear wife. I wasn't going to write anything about it, but if you could realize how I $\underline{\text { do }}$ want to see my darling little sweetheart, and how homesick I get sometimes dear. Still I always try to look ahead to Washington and to be brave, for my dear wife's sake.

With lots \& lots \& lots of love and kisses from

Austin

Comox, Vancouver Is. May 14, 1906

Dearest, dearest wife,

We arrived here this morning early from Seattle to get coal. We had perfect weather coming up the sound, perfectly smooth, and pleasant, although cloudy. Everything is fine. We shipped 11 new men at the Bremerton Navy yard at about 11 in the morning, and 4 of them ran away that night at Seattle. Metters went after them and caught them; there is going to be a court martial on board today. I have just time to get this letter in now for this mail, but I shall write you a nice long one this afternoon dearest.

Heaps \& heaps of love and kisses

\section{Austin}


Union Bay, Vancouver Isl. May 14, 1906

Dearest, dearest wife,

Everything is going on swimmingly: I am getting lots of notes about birds, and quite a number of specimens. Everything is peaceful and harmonious on the ship. I believe I told you that four of the men we shipped at Bremerton decamped on reaching Seattle, and were caught. Do you remember a tall good looking chap whom I told you was the paymaster's "yeoman"? He was one of them. He is at present in the jail in irons. The young Chinese "Mow" was also a deserter at Seattle, but was not recaptured. We are going to hold a court martial tomorrow. Mr. Hepburn is president of the court. It is awfully pretty here; all great pine and fir trees, like Maine, only the trees are ever so much taller; so tall that you can't hit a bird in the upper branches with a gun. The little town of "Union Bay" is in a pretty little clearing in the woods. The houses are all cheap wooden ones, the prevalence of stumps sticking up all about you is a decidedly backwoodsy air. The main feature is the long wharf where they coal ships. The trains run along a track about $30 \mathrm{ft}$. above the main wharf, and they shoot coal down inclines on the decks of the steamers, where the sailors get after it with shovels and shovel it into the bunkers. The big German steamer "Uarda" which was in S.F. at the time of the earthquake is on the other side of the wharf from us. She was just coming in the Golden Gate when it happened, and thought she had struck a rock. When she got in she went into dry dock at once to ascertain what the damage had been and found none at all. There is a big coal steamer lying in front of us from Newcastle-on-Tyne, England. The mail boat for the U.S. arrives and departs tomorrow at 8 a.m. I can hardly wait, I am so anxious to go and get my letters. I am awfully sorry, dear sweetheart that I couldn't manage to have my pictures taken in Tacoma or Seattle, but we only stayed at Tacoma one night, getting in at 6 and leaving at 8 next morning, and we were only in Seattle part of a day so I couldn't arrange it. There is no photographer near here. However, dearest, I shall have them taken first thing when I strike Japan. It is hard work, darling, to not write you how I long to see my dear, dear, brave little wife again, and how sort of lonely I feel way out here, but I won't say anything about it. I do love you so much dearest, dearest Mary and will be so glad when we are together again. I am looking forward to it all the time. Well, May is nearly half over dear, now. I do hope you have just the very best time in Europe, dearest, and I know my darling little wife will take the best care of herself, as I am doing of myself for her sake.

With lots \& lots \& lots of love \& heaps of kisses

\section{Austin}

Union Bay, Vancouver May 15, 1906

Dearest dearest wife,

I have got together quite a collection of birds now, and lots of notes, which ought to make a great showing when I get them all worked up. The other people have been collecting fishes and all sorts of other things along the shore. We haven't had our court-martial yet, but expect to tomorrow. The captain is making the men work coaling ship, so they won't be tried until that is done. Do you remember old Jacobson, who I told you assisted me, besides Teed, the man in the laboratory (Fig. 23, 24)? He has been gloriously drunk for the last three days, but appears sober today. I suspect he laid in a supply of perfumes before going to sea. I left the laboratory a minute the other day and when I came back, I found him at the alcohol faucet. He skipped quick, and hadn't had time to get any. It is funny how wild the sailors are for the alcohol. I forgot to tell you the funny thing that happened the first day we left Seattle. In the evening Dr. Gilbert came into the laboratory where Dr. Torrey and I were smoking pipes. He captured Dr. Torrey and talked to him for a while, then took me outside and told me that smoking in the lab was against the rules. I told him it wasn't and showed him the rules, but he said it was, and always had been and anyhow it was obnoxious to him. That being the case, I told him I wouldn't smoke in the lab anymore. I found he had been saying the same thing to Dr. Torrey. Well, later on, in walks the captain, smoking a cigar, which he continued to smoke as long as he was in the lab. Dr. G. apparently didn't like it, but it showed him that it really wasn't against the rules. The skipper has been very sweet lately; hasn't sat on anyone, even Tongue. Everybody seems to be in especially good humor. I am impatient to be off, for when we reach Unalaska, the second stage of our journey will be over, dearest, and the prospect of seeing you again so much nearer. Do you think I am silly to love my little wifey so, and to be so sort of homesick to see her, dearest? Mr. Hepburn told me Mrs. H. reached Colorado Springs all right, and is staying with relatives there. She succeeded in getting a section all right. I don't know where Mrs. McCullough is (and don't care!), but I believe she is somewhere in southern Calif. I wonder what became of Aunt Mary and the girls; did they come back east, or what? Well, au revoir, dearest wife; I shall keep a diary every day, darling, and send it to you from Unalaska.

Heaps of love and kisses,

Austin 


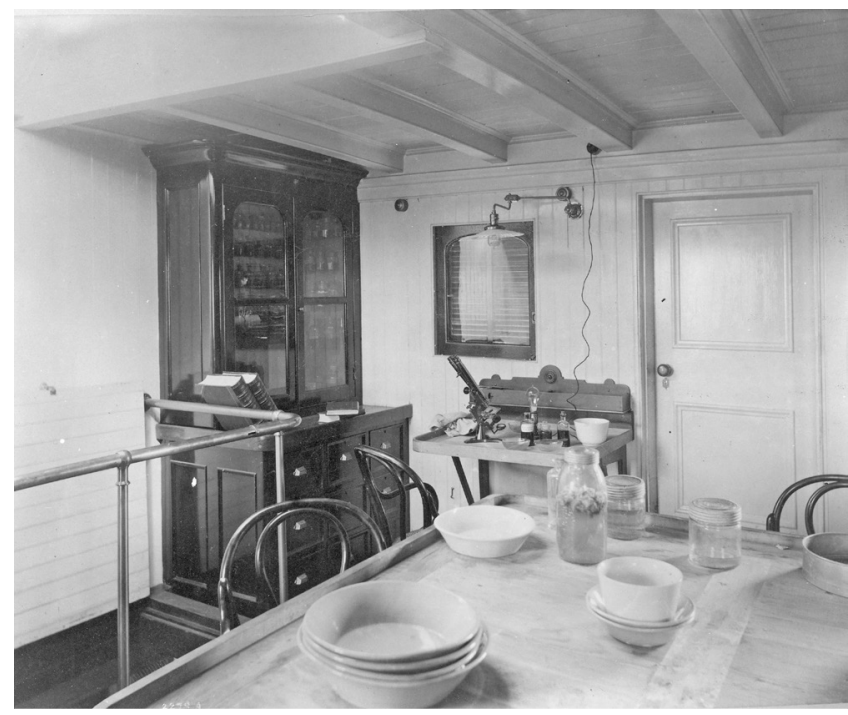

Figure 23.-Upper laboratory on Albatross, where Clark and others fixed and preserved specimens. U.S. National Archives.

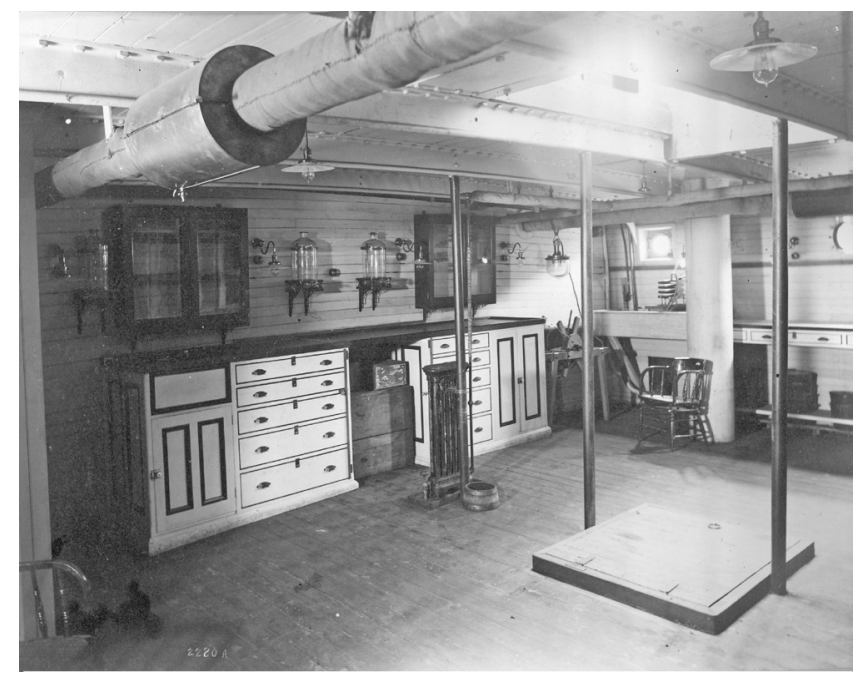

Figure 24.- Lower laboratory. U.S. National Archives.

with the tame bear they used to have, etc. Well, dearest, I am afraid I will not be able to send any letters to you for nearly a week now, but I shall write every night, dearest, just as I did before, and send it all from Unalaska. It sort of makes it less lonesome if I sit down every evening before going to bed and write to the dear, dear little wife I love so much even if I can't send it just then. Well, au revoir, darling.

Piles and piles of love and heaps of kisses,

Austin

Comox, Vancouver Isl.

May 15, 1906

Dear Papa,

We arrived here day before yesterday from Seattle, and leave today for Dutch Harbor, Unalaska, en route to Hakodate. We had it rather rough coming up from S.F., but it has been fine in the sound. We called in here for coal. Nothing special has been happening. Everything is quiet, and everybody is well on board. The weather is very nice; cloudy, but warm. The country here is very fine, mostly great fir forests, with snow mountains beyond. My address now is "care U.S. Consul, Hakodate, Japan."

$$
\text { Aff. A. }
$$

er. We have finished coaling now, and have all the coal bunkers full, and coal stowed in sacks piled up along the rail on each side. It is a nuisance, as it makes the passage for walking about very narrow, but they say it will all be below pretty soon. Everything is peaceful here. None of the men have been allowed ashore, consequently no one is drunk. The sailors are a queer sight: they are all dressed in their clean white clothes today, and are just a mess of coal dust from head to foot. They have been telling tales about the ship's goat at supper tonight; how he chewed the rubber bulb off Mr. Agassiz's camera as he was focusing in to take a picture, his fight
May 17. Started very early in the morning from Union Bay, Vancouver Island for Dutch Harbor, Unalaska, via the "inland passage; i.e., between Vancouver Island and the mainland. We passed all day along a winding channel, sometimes several miles wide, sometimes very narrow, the shores rounded hills, covered with firs, with here and there an Indian village or a lumber slide in a clearinggrown up to deciduous trees. The hills nearest the water 
were dark green, farther off blue, and in the distance the snow mountains of British Columbia, and the interior of Vancouver stood out sharp against the sky. The water was as smooth as a mill pond; the ship was even steadier than when we were anchored in San Francisco, and the air was clear and still. Everybody enjoyed it, especially the paymaster. In the evening we anchored near the end of Vancouver's Island, not far from the end of the Seymour narrows, as there are no light houses or markers by which sailing may be done at night in these inland waters.

May 18. Started out about 7 o'clock and wound our way along the channel till it broadened out, and we reached the open sea about 2 p.m. The sea was very smooth, and only one man, the student Burke showed any signs of turning a bit green around the gills. Nothing has happened all day; we just steamed peacefully along, headed for Unalaska, 1500 miles away. The albatrosses, which we did not see after passing the mouth of the Columbia River, reappeared in abundance. Beat Tongue at a game of chess in the afternoon. Everybody ate breakfast, but we missed Burke at lunch and dinner. Mr. Snyder and the paymaster were apparently a bit uncomfortable: everybody else cheerful.

May 19. Got rougher during the night. At 10 a.m. we made a haul with the big tow net, and got lots of funny things, among other several deep-sea phosphorescent fishes, and some green jelly fishes, deep maroon(?) color, and lots of funny little shrimps. Just before the tow I fished for albatrosses from the stern with a long line baited with pork. I hooked one, and hauled it nearly to the boat but it got away. I hooked another, but the line broke. When the ship was stopped for towing, I got them near the boat by towing a piece of pork on a string behind and the doctor shot 2 . I went out in a boat with a couple of sailors and picked them up. They are most tremendous great birds, weighing about 10 pounds, and spreading about 8 feet across the wings. It was funny way out on the ocean in the little boat picking up birds, we were quite a way off and the Albatross looked so small, bobbing up and down in the distance with no other boat in sight, surrounded by these enormous birds, which had collected to see what was happening to their comrades. It got rougher this afternoon, and there were several gaps in the line-up for dinner. When I said goodnight to the paymaster, I shook his hand and said I supposed I shouldn't see him again until we reached Unalaska. The time jumped back half an hour yesterday, and twenty minutes today.

May 20. Sea very smooth, so all the invalids reappeared at meals; took a haul with the big tow net in the morning, hauling the net for 20 minutes at 1800 feet below the surface: brought up some funny deep sea fish. Skipper particularly jovial: has been very sweet all along since leaving. Dr. Torrey does not seem to appreciate Prine. Yesterday Prine detected him feeding the fishes over the rail, and sung out "Hold on to your hair, that's going next," and Dr. Torrey didn't like it. Got into a discussion at the table this evening as to whether flying fishes really fly: Mr. Hepburn and I said they really waggled their wings, because we had seen them do it; the doctor and Mr. Snyder said they didn't because they had no muscles to do it with; we said we didn't care about their muscles, they did just the same. It was lots of fun.

May 21. Much rougher today. Dr. Gilbert wanted a net got ready for a deep sea dredge. The nets used in this work are 13 or more feet long, and about 10 wide at the mouth, which is fastened to a heavy iron frame, weighing about $200 \mathrm{lbs}$. He said he wanted a certain kind known as a "Blake" trawl. I got one fixed up after about 2 hours and asked him to look at it, and he said it wasn't at all what he wanted, but to use a different kind known as the "Agassiz". Now Mr. Chamberlain has got up a new kind of net to use on the Agassiz frame, which is a great improvement over the old style. Dr. Gilbert especially said he didn't want to use Mr. Chamberlain's net. Well Teed and I put the frame together and, not being able to find one of the old style nets to fit, we put on the new one of Mr. Chamberlain's. I got Dr. Gilbert to look at it, expecting he would make us hunt up some other net and do all the work over again, but he was quite tickled with it, and thought it was great. I didn't tell him it was Mr. Chamberlain's net. He hates Mr. C. and that was the main reason for his not wanting to use his net. I told you he told Dr. Torrey and me not to smoke in the laboratory; well, today he told me that it was a pity I smoked, because I had the "makings" of a naturalist in me, and he knew a young man who gave promise of being a naturalist once who was ruined by smoking. I told the doctor, and it amused him very much. He said I ought to have told him I knew some men who were ruined by being cranks. Oh, I forgot to say, that Chamberlain had told me that whatever I did for him in the net line he would want done differently, especially if he knew he (Mr. C.) had anything to do with it: came out true, didn't it? We took a tow-net haul today, and got some funny deep sea fish. We towed the net for 20 minutes 1800 feet under the water. We got a fine large dark red jellyfish, too. Dr. Torrey had it in a big wash basin in the lab (he was as tickled over it as a child with a new toy), and a big roll came and it sloshed over and fell on the floor and smashed all to bits. We put up the sails after taking the tow, and scooted along at a great rate. It is getting rougher now.

May 22. Fine and rough last night: couldn't get to sleep at all: whenever I dropped off, a big roll would come, so I had to hang on to the edge of my bunk. Once I looked over and saw the window of my room in the floor. That time I really fell out, so I got up to see what could be done. The mattresses on the bunks are on slats, so I fished out the slats from underneath my mattress: that let it down about 4 inches, giving me so much more rim to grab when the ship 


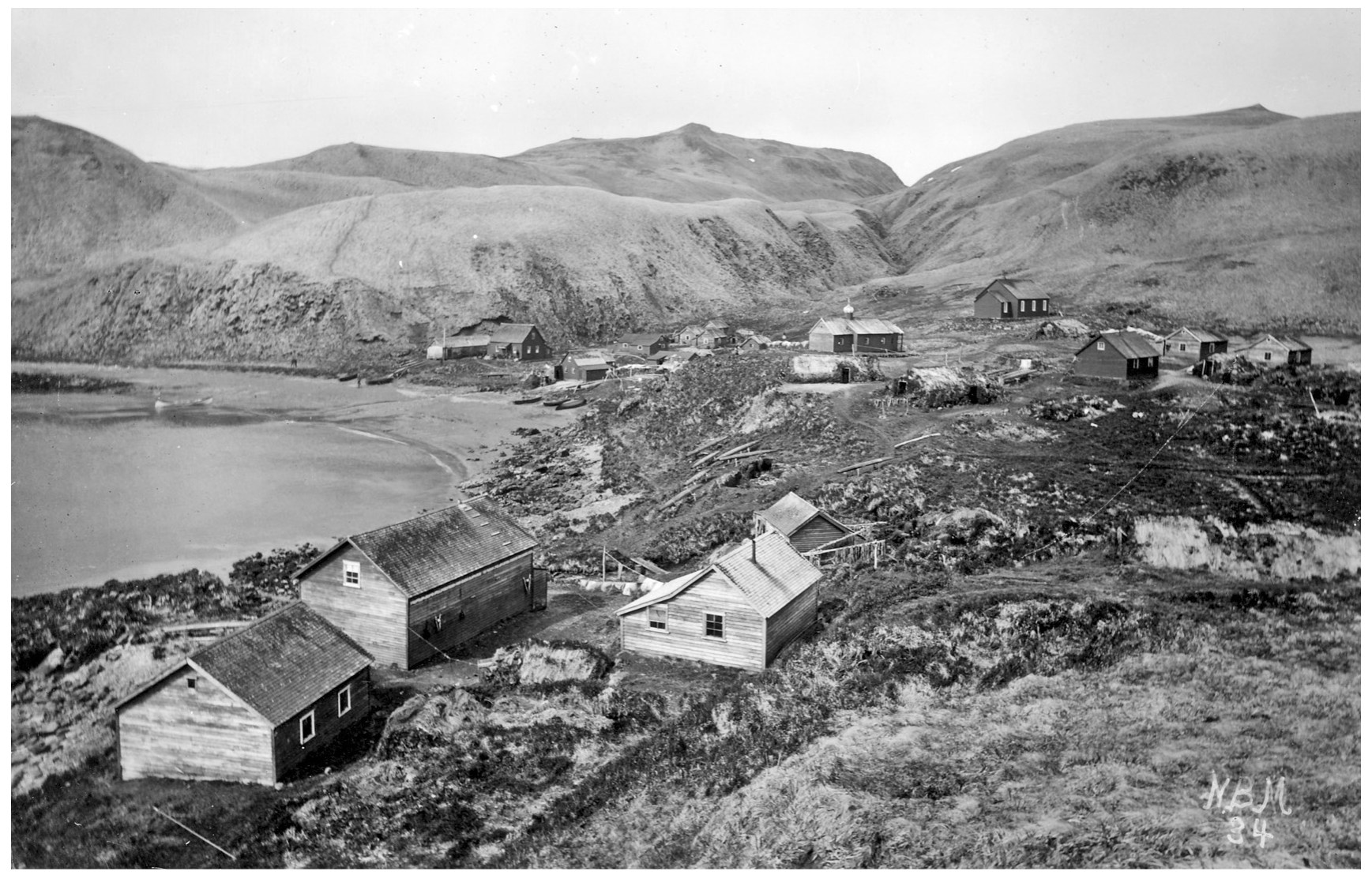

Figure 25.-Dutch Harbor, Unalaska, Alaska. U.S. National Archives.

rolled. I took 2 of the slats, and poked them in between the mattress and the side of the bed, and fastened the other ends to a curtain pole on the ceiling, so as to make a sort of cage, so I can't tumble out no matter what happens; only fall against the grating of my cage. Sogie, the Jap with the moustache was walking down the deck today, when Buck spied him, and made for him, catching him square where he sits down and landing him in a heap. The sailors have made Buck a coat out of an old blanket, so he won't feel the cold. We had a great time at dinner tonight: everything skated all over the table, and usually ended up on Mr. Hepburn. Do you remember the grating right inside the pantry, that leads down to a hold underneath, where the ginger ale and apollinaris is kept? Well, that was open, and in one of the rolls we saw Ming, the steward, sliding toward the hole on his hands and knees, hollering for help, and surrounded by flying dishes and glasses. It was awfully funny. Another time Ming was coming down the stair with a tray of eatables, and just as the ship gave a tremendous roll, he stepped on the cat, which was lying asleep and slipped. He went clear under the table and out on the floor to in front of the piano, all in a heap, with his pigtail sticking straight our hollering 'Dog, dog, dog, dog.” This evening Sogie started to bring me a plate of soup and was going around Mr. Hepburn's end of the table; but a big roll came and Sogie landed on the transom, and the soup way up on the wall near the ceiling. The sea is going down now, and I expect it will be smooth tomorrow.

May 23. Fine and smooth. The Aleutian Islands were visible at daylight; great snowy peaks rising up out of the clouds. We steamed toward them, and passed up a channel between Unalaska and another island about 2, and came into the town of Dutch Harbor (Fig. 25), on Unalaska.

Dutch Harbor is a queer little place, just coal sheds, a long wharf, and four or five houses. Its resident population is 6 , but when a boat comes in, more came over from the other villages to help coal. The mountains are all snow-capped, and there is lots of snow on the lower levels too. It is rather cold from $40^{\circ}$ to $47^{\circ}$. The sun did not set until nearly nine, and will rise about 2:30; it hardly gets dark all night. When we tied up, all the sailors had lines overboard and soon had lots of codfish. I went up to the Post Office, and found that the mail did not leave until June 8, so I thought, dearest, I would just keep this diary every day, and send it along when we left. 


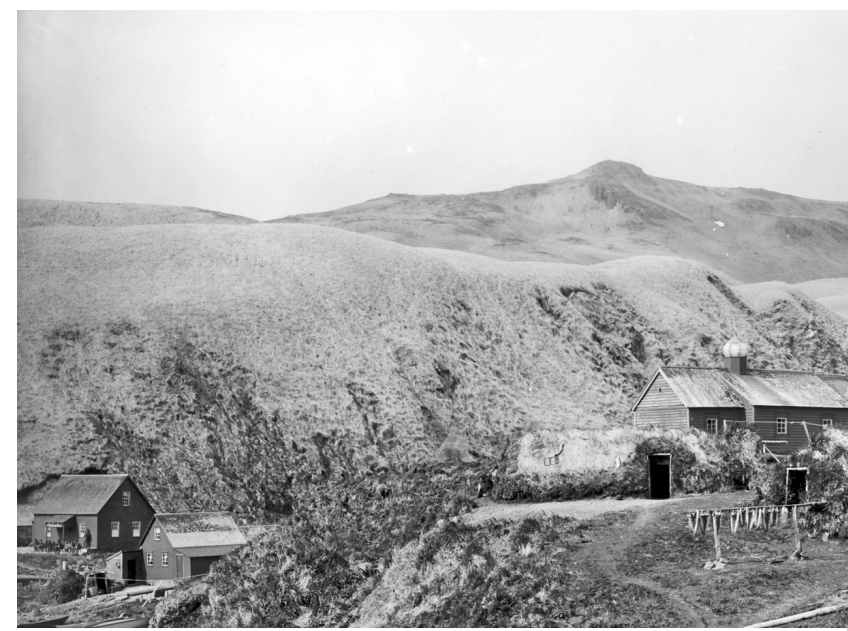

Figure 26.-Atka, Alaska. U.S. National Archives.

May 24. Went out shooting and got quite a lot of birds. Lots of eagles here. It rained lightly most of the day. Crater went fishing with Metters, and caught 2 small trout. Metters wanted a catgut leader to put a fish hook on, and couldn't find any, so he swiped the E string from Tongues guitar to make one. It is quite cold today and dark. They have been coaling all day. I counted the houses in Dutch Harbor today; 4 houses and 2 stores. Quite a city isn't it? The steamer "Corwin" of Boston is in here, with 95 passengers bound for the gold fields above Nome. She is always the first steamer to get to Nome after the ice gets out. It begins to break up about June 15. She comes from Seattle, and is much smaller than the Albatross. This was a great place during the gold rush to Alaska, as all the steamers put in here, but with the dying out of the rush business has slackened, and everybody is getting out. The population of the island is only 400 now, most of them live at Unalaska town.

\section{Dutch Harbor, Unalaska} May 25, 1906

Dearest, dearest wife,

We leave early tomorrow morning for Atka Island (Fig. 26, 27), and from there to Attu. This is one of the funniest places I ever saw. The people are mostly Indians, with Russians and some Americans. There is a Russian church at Unalaska, and a graveyard with Russian names on the tombstones. Their tombstones are all of wood in the shape of a Russian cross, like this.

Crater and I went hunting ptarmigan today on a large mountain behind Dutch Harbor (Fig. $25,28)$. We shot 5 , and some other birds. We had a hard day of it. The ground was very steep and in many places the snow was up to our waists. It was snowing heavily most of the time. Well, dearest wife, the first stage of this journey is over, and we begin the second stage tomorrow. Somehow, on leaving here, I sort of feel as if it wouldn't be so long before I see you again, dear little sweetheart. We are going to Petropavlovsk, Kamchatka, via Atka, Attu, and Aggatu Islands. The weather is great now, and the sea is nice and calm, so I expect we shall have a good trip. I bought a cute little pair of slippers for you yesterday, dearest, made out of seal skin with the fur on it, and ornamented with beads. They were made by the Indians here. They have lovely furs for sale here, especially sea-otter skins, for $\$ 600$ each. I have a dandy collection of the birds of this place now, and am anxious to get away. Everything is going fine and smooth. Old Jacobson got drunk yesterday and the master-at-arms (the ship's policeman) also got drunk, and now in irons in the jail, with Teed keeping watch on him. It is cold, but we have steam heat in the cabin, and are as cozy as can be. Well, dearest, the ship is just leaving so I am afraid I must close. God bless you, darling wife, I do so hope my little sweetheart has a good time this summer. Won't we have a time swapping experiences, dearest? My address in care U.S. Consul, Hakodate, Japan, now. I am so lonely, darling, but I try to look ahead to Washington and to keep a good heart. Well, dearest good by: I will write from Attu and Atka, if there are any post offices there.

Lots \& lots \& lots \& lots of love and kisses Austin

\section{Atka Island}

May 30, 1906

\section{Dearest, dearest Mary,}

There is just a chance I may be able to send a letter from here, so I am going to write anyway, and have it ready. We got here early, and it is mountainous. There are no trees, the mountains being covered with dry grass. Most of the mountains, in fact all but the lowlands, are under snow. The village is in a little bay, and consists of 20 or so houses, about half, small wooden ones, and half out of thick clumps of sod. They reek with the smell of fish. The natives have lots of fish hanging up to dry everywhere. There are 120 people in the village, one white man and the rest Aleuts, the local race of Indian. We just arrived from Unalaska. Yesterday we passed Bogoslov Island, a little active volcano. Bogoslov has a funny history. It just appeared, a single small island, in 1760; in 1883 another small island appeared near the first covered with cracks and steaming all over. This quieted down, and sometime this last winter a third island arose, between the other two, which is still steaming violently.

How do you think you would like to live here? The mail leaves twice a year to Unalaska. The white man here did not know the war between Russia and Japan had ended until we told him. Of course, he had not heard about San 


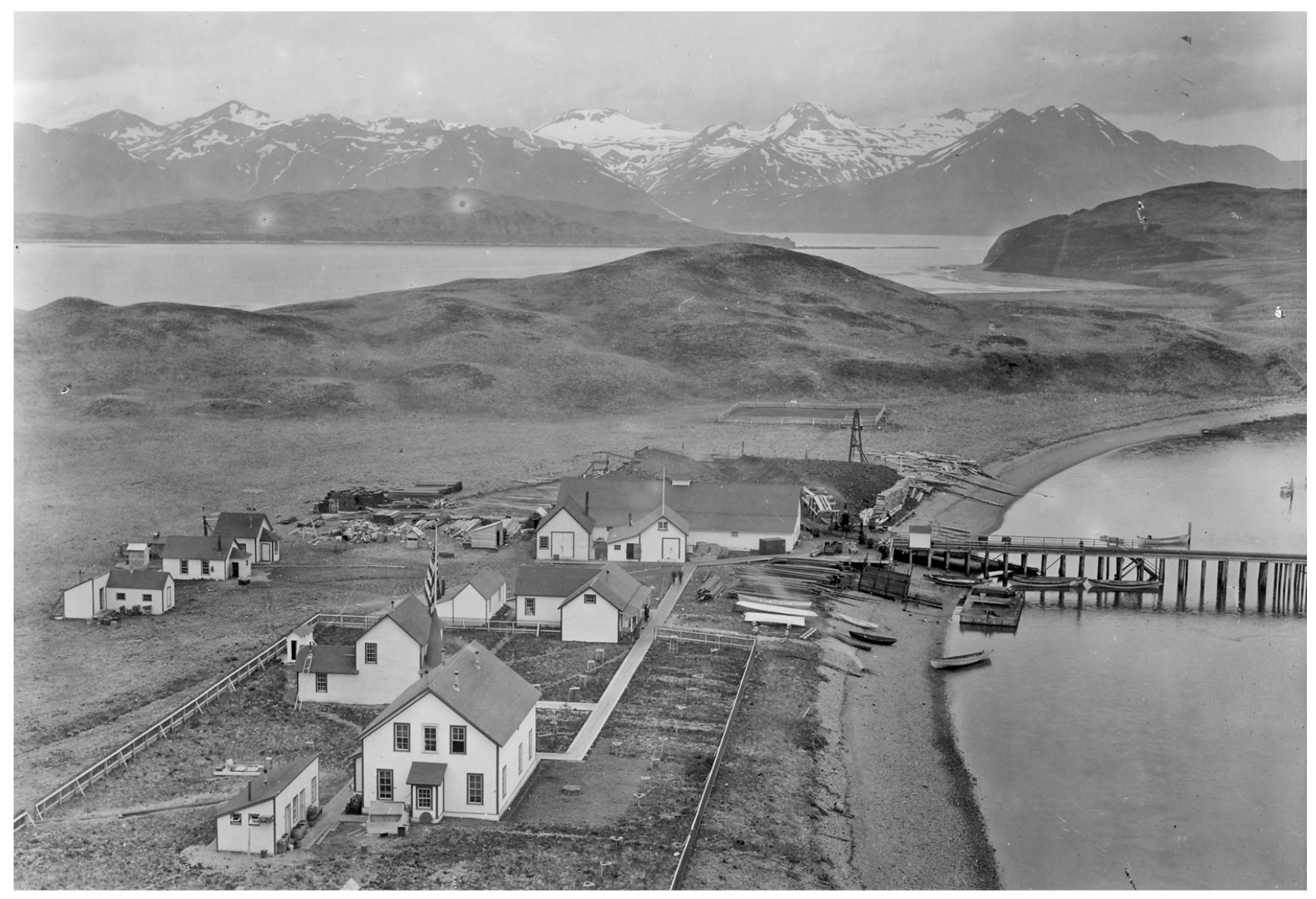

Figure 27.-Atka, Alaska. Note fish drying in center right. U.S. National Archives.

Francisco. The nights do not get dark at all now; the sun sets at 9 or later, and rises at 2:30; twilight and the aurora bridge on the intervening hours. There are active volcanoes all about here, on this island and on neighboring ones. Earthquakes happen frequently, but are never violent. There is a little Russian church here, as at Unalaska, with five bells on a trellis behind it. The people here hunt blue foxes and catch fish for a living.; they are funny looking Indians, and awfully shy; all sneak into their houses when anyone comes around. We are going tomorrow to Attu, which is about the same as this. None of the Indians understand anything but their own language. There used to be a lot of them here, but measles nearly killed them off a few years ago, and pneumonia the next winter nearly finished the job. I am getting lots of nice birds, and will have quite a collection when I get back. Well, dearest sweetheart, another stage of the trip is over, and I am so much nearer seeing you again, dear. I keep my courage up by looking ahead to Washington, dearest.

Lots \& lots \& lots \& lots of love and kisses,

\section{Austin}

Petropavlovski

Amur Province, Siberia

June 16, 1906

Dearest dearest sweetheart,

We are just coming into Petropavlovski (Fig. 29) from Komondorski Islands. I have not been able to keep my diary in decent shape since leaving Atka; so I am going to copy it into this letter. We left for Agattu Island (just south of Attu), and did a lot of dredging north of Kiska Island on Bower's Bank (lat. 55n.) and then went south to Petral Bank, just north of Semisopochnoi Island, then around that island to Agattu, where we spent a night and a day. We came in on the east side of Agattu, in a sort of open bay where it was nice and sheltered and spent the night, and went on shore the next morning. There are no people on Agattu: it is simply a hilly island with a couple of volcanoes, covered with long dry grass and patches of snow. There are thousands of sea birds, mainly puffins or sea parrots along the shores, and lots of big eider-down ducks. We got a nest of one of these ducks with 4 eggs. Inland away from the sea there are lots and lots of wild geese: you 


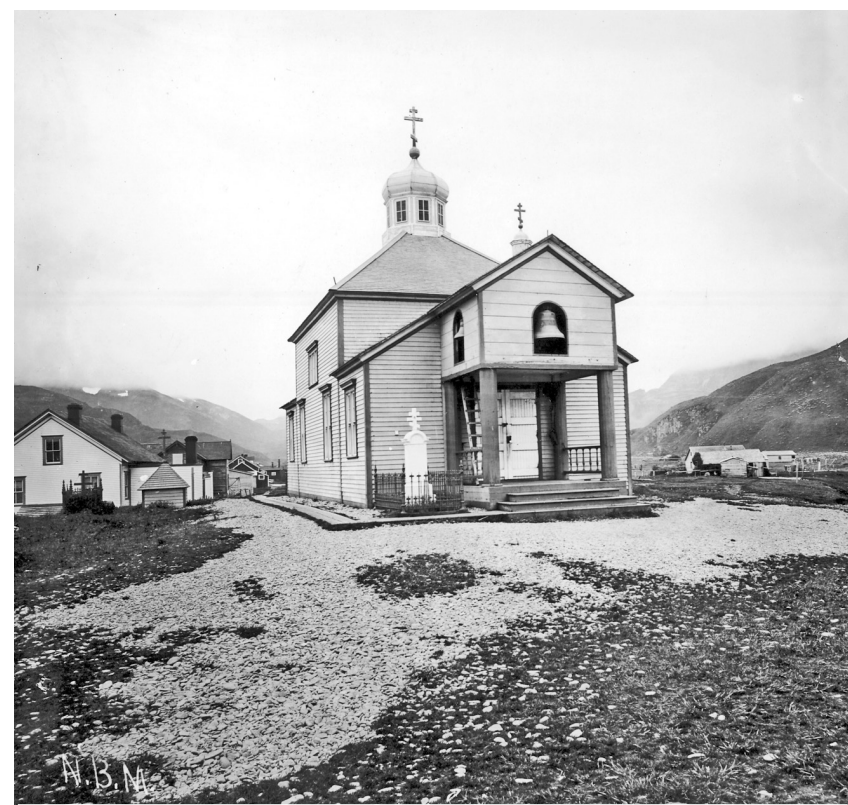

Figure 28.-Russian Orthodox Church at Dutch Harbor, Unalaska, Alaska. U.S. National Archives.

can see them walking and flying about everywhere. I shot 9 of them; nice big ones. After we had been ashore (Fig. 30) a couple of hours, we heard the whistle blow and had to come off to the ship: the wind had shifted, so it was blowing onto the shore where we were anchored, and was blowing pretty strong. We got up anchor, and started for Attu Island doing some dredging on the way. You know what a jolly sort of person the paymaster is, always wanting to play jokes on people? Well, I played a joke on him going to Attu and he got so mad it was several days before he could see the funny side of it. He was in the bathroom taking a bath, and was in the tub: I walked up to the door, knocked, and said as gruffly as I could "The captain wished to see you, sir", so he would think the captain had sent the quartermaster after him. I really didn't think he would bite, but about 5 minutes later, I was standing in the bow of the boat talking to Crater, and we saw him rush by, buttoning up his clothes as he went: he hustled up the bridge and started apologizing to the captain for not coming quicker, saying he had been in the bath. The skipper sort of looked funny and told him he was glad to see him, but he had not sent for him. Pay was mad for a couple of days, but then saw the funny side of it. I told you that the paymaster heartily dislikes the doctor and Dr. Torrey, didn't I? Well we played them a neat trick at Attu. All the day before they had been talking about Attu baskets, and as soon as the boat got in (about 5 o'clock) they went ashore to buy some: but unfortunately the people of the village had all gone away salmon fishing, and were camped on a lake, about 7 miles away. When they came aboard, they made plans to start about 5 o'clock the next morning and walk to the village, so they could get first choice at any baskets the people might have for sale. Crater and I were going ashore after ptarmigan about 4 the next morning, and were much surprised to find Pay already up when we were down to breakfast. We asked him what got him up so early, and he said he was going shooting, and asked if he could go ashore in our boat. We landed near where we were anchored, but he took the boat and went on to the town. About an hour later, we looked down on the town from a high mountain behind it, and was surprised to see him several miles behind it, walking as fast as he could go on the trail to the encampment where the people were. When the surgeon and Dr. Torrey went ashore, they found the man who had offered to guide them to the other village gone, but set out on the trail alone. About half way they met the paymaster, with all the baskets he could carry, tied about him, and both arms full, bringing up the rear of a troop of 30 Indians; all with baskets which he had bought: he had gone over to the other town, taking with him the man who had promised to guide the doctor's party, and bought every basket on the island. The surgeon was just ripping mad. I never saw people laugh so as the officers did the next few days; it certainly was funny. He could hardly get his purchases into his room, he had so many. In the evening he spread out all he had, and distributed them around for what he had paid for them: he didn't want them at all, he only wanted to get it back on the doctor for being mean enough to try and get all the best baskets before anyone else had a show; and he certainly did: the mere mention of baskets now has a worse effects on the doctor than a red rag to a bull. I got three nice baskets, dearest, two big ones and a little one for $\$ 2.25$, which considering, they sell up in these islands for about $\$ 5$ each was quite reasonable. Attu is a fairly large island, very mountainous and with a beautiful little land-locked harbor, barely big enough for 3 boats to ride at anchor. The chief town, Tchichigov, has 2 or 3 small wooden houses (including the store), a wooden church, with a thatch roof, and about a dozen houses made of sods, and dug out into the ground, so that the top of the roof is only about 4 feet above the surface. The full population is 74, all Aleutian Indians. When we arrived, all but 4 were away catching salmon on a stream which drains a big lake 7 miles south across the island. The morning after we arrived, Crater and I took a long walk over the mountains after ptarmigan (a kind of grouse, pure white in winter, brown in summer), but didn't see any until late in the P.M. (we had started early in the morning) when he found one which he shot. It was snowing most of the time in the mountains and raining in the low places, so we got soaked, and were glad to get back. When we got back, one of the men who had been up on the top of some of the mountains on the South side of the harbor told us he had never seen ptarmigan so plentiful as he found them there; so next morning we got up early and with this other man as guide, set out again. We got to 


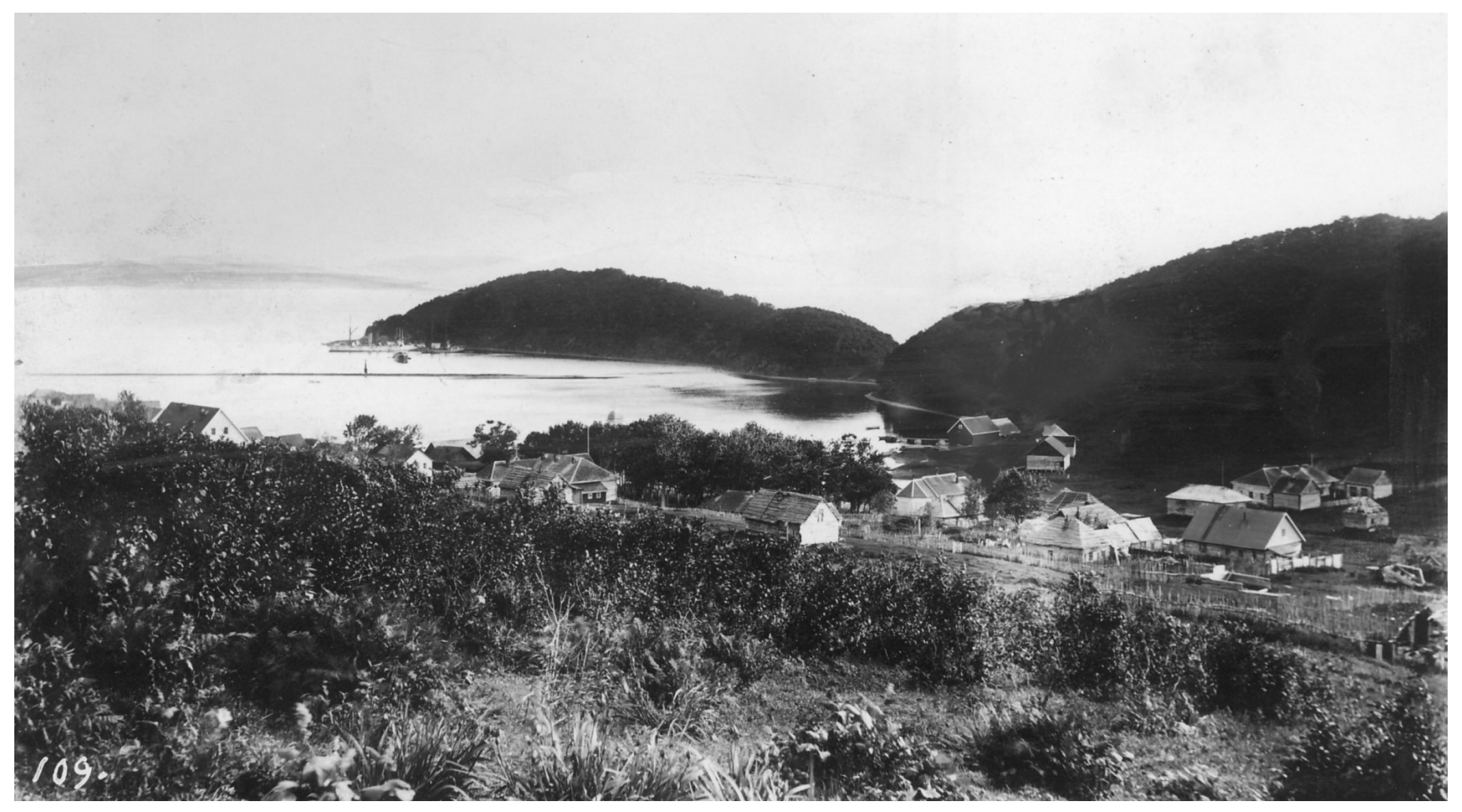

Figure 29.--Petropavlovsk-Kamchatsky. U.S. National Archives.

where he said they had been so common the day before, but we didn't see a single one. We hunted about for a couple of hours, and finally got one, and then got disgusted, and came down, and took a walk along the rocks by the seacoast after ducks. Crater shot two eiders, but we couldn't get them. We got aboard about 4, and then left for Medni [sic] island (a Copper Island) in the Komandorski or Commander group (Russian). I hoped to be able to send some letters from Attu, dearest; but we found that the last ship in had been a Russian ship, a year ago last month; so you see the mail facilities are not as great even as at Atka. The people are in a rather bad way as to clothes and provisions. Many of the youngsters are barefoot, and one was running about in the rain and sleet with only a small shirt and antique vest on; no lower works at all. I saw him paddling about in the snow, and wondered how on earth he stood it. He was only a little chap, 7 or so. We did some dredging between Attu and Medni and got to the latter island 2 days later. This island is rather small, but the town is very clean, all the houses being of wood, and in good repair. It would give credit to New England any day. The population is 240, 6 white and the rest Indians. Medni is high and mountainous, but barren and not grassy like the other islands. The town is in a little valley which runs back a mile and a half from the sea and is very pretty. On the lower hillside there is a thick matting of moss, with the native Rhododendron, a funny dwarf variety about 6 inches high and lemon yellow peeping through everywhere. There are lots of violets and pink primroses and buttercups and wild heliotrope too. The mountains are all rocks and mud, with no vegetation. The people here get their living from the great fur-seal rookery on the island. It is rather early for the seals yet, and only 7 had arrived. Crater and I went ashore here and hunted all over the mountains after ptarmigan, but couldn't find any at all. We only stayed here a day and cleared out early the next morning for Bering Island (Fig. 31), the other island in the Komordorski group, and very much larger than the other Aleutians. We dredged all day, and then drifted around all night, getting into Bering Island early the next morning. This island is where the Danish navigator Bering, who discovered Bering Sea and Alaska, died and was buried. He was employed by the Russian government; you know that Alaska and the Aleutian Islands used to belong to Russia, but Alaska and all the Aleutians, except for the Commander Islands, were bought by the U.S. for $\$ 5,000,000$. The town on Bering Island is on a natural harbor by the side of a river which flows out of a large lake about 2 miles inland. It is a larger town than any of the others we have been to, and nice and neat, like the town on Medni. The population is about 500, with about twice as many dogs. The governor of the Komordorski islands, a military officer, a custom house officer, and a Russian doctor live here: all the rest are Indians. Here and at Medni we saw washing hanging out to dry, rather a strange thing in the Aleutian Islands, as washing is not considered at all necessary, either for 
clothes or human beings. The furs bought by the people on board proved to be tenanted by mysterious insects, lots of them, too, whose presence betokened an unwashed community, (I refer, however, to the furs bought at Attu.) We had a whole day at Bering Island, which I spent asking after birds with a sailor named Hanson; a nice young chap, who is stationed in the laboratory now. I think I told you that Teed, who used to be in the laboratory, is now the master-at-arms; the duties of that office being to keep order on board and look out that everything runs smoothly; in fact, to be a sort of ship's policeman. The man who used to have the job, a rascal named Riley, got drunk and raised all kinds of cain at Unalaska and got reduced to stoker in the fire room, and Teed took his place, so they sent Hanson in here. Hanson is a young Swede, and a nice, bright chap about 23 years old. I forgot to tell you another joke the paymaster played on Dr. Torrey. One day just as the deep sea dredge was coming up, he got a lot of potato sprouts, an put them into the net, so that Dr, Torrey would find them and think they were some rare species of soft coral or something. It worked great. We have had very smooth weather since leaving Agattu, hardly as much as a ripple at any time. It is most remarkable for this locality. We have had two sunny days, another peculiar circumstance, as sunny days are very rare in Bering sea; the general rule is fog and rain. One man writes that he was in the Aleutian islands for 30 consecutive months and only saw 6 pleasant days the whole time. We have been fairly free of rains, and although it has been misty, we have not had any bad fog at all. Fog doesn't make much difference here, as there is nothing to run into. We saw a small schooner anchored at Atka, and a German steamer at Bering Island; those are the only ships we have seen. The steamer had Chinese letters on her side, and was being run by the Kamchatka Commercial Co., which runs all businesses in these parts. This letter will go a long distance before reaching you dearest wife; perhaps it would go quicker from Hakodate. It goes by dog-sledge from Petropavlovski to Irkutsk, in Siberia, then by the Trans-Siberian railway to Moscow, then to Berlin, Hamburg, and New York. We are getting into Petropavlovski harbor now. It is a deep harbor with hilly sides, covered with small trees, and with great snowcapped mountains behind the town. It seems nice to see trees again, if only small ones; there are none on the Aleutian Islands: the people there depend entirely upon drift wood. There is a willow there, but it only creeps along the ground, like a vine. The tallest bush is about a foot.

Went ashore with the officers after supper. The town is sort of on the principal of villages we saw out Wyoming way, only there are swarms and swarms of dogs. When a strange ship comes in here they have to tie up all the dogs, as they would tear strangers to pieces. They are the big sledge-dogs, which take the place of horses here. The doctor asked one of the merchants about furs, and he told him that all the furs on the Aleutians now were skins which the traders had refused as second class; mostly from animals

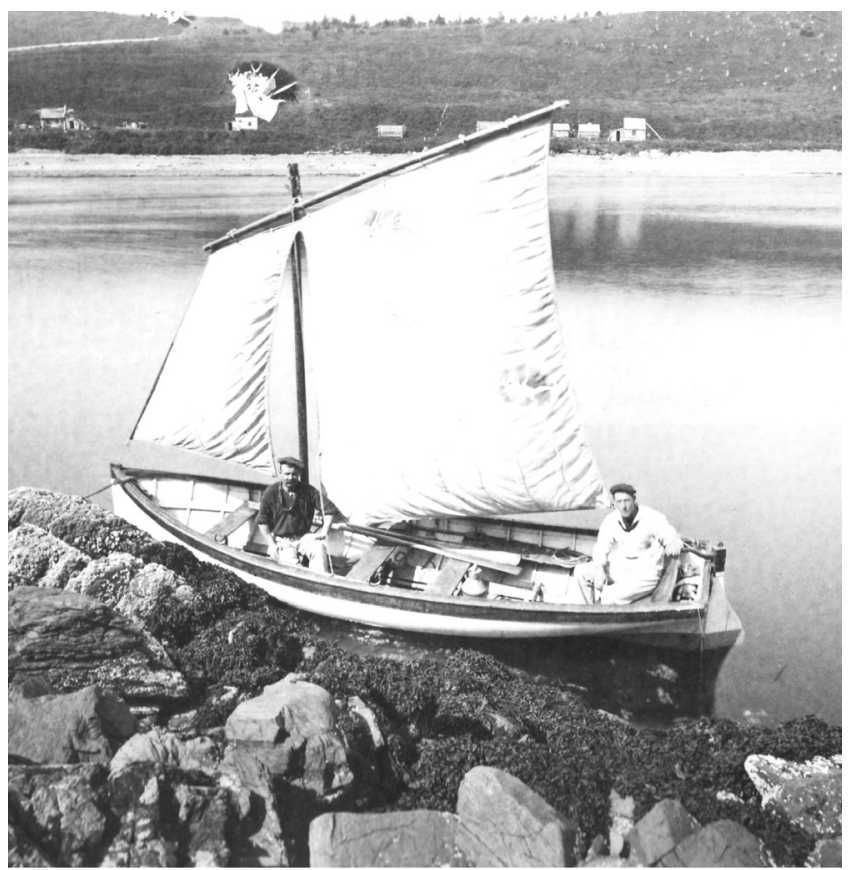

Figure 30.-Dinghy from Albatross, Alaska. U.S. National Archives.

found dead; and that if he pulled the hair on any of the skins he bought, he would find it came out easily, which indicated that the animal had been dead quite a while before being skinned. The doctor as soon as he came on board got out his fox-skins, and found sure enough, that the hair pulled out easily; all the others who had bought skins tried it also with the same result. We who had not bought any had a good laugh on them.

June 17. Had great times last night; a lot of the men went ashore, and got drunk with vodka. When they came aboard, Mr. Hepburn searched their boat and found 38 bottles of it hidden under the seats. He and Hazard smashed all the bottles and threw them overboard. About quarter past $11 \mathrm{I}$ heard some one in the laboratory, and went in and found some men trying to get at the alcohol. They were scared away three times and the last time I went and asked Mr. H. to send a man in there to watch things. He sent Teed in with a great iron belaying-pin and told him to lay out anyone who tried to get in, and not to be afraid of killing them, but no one else ventured. Most of the sailors are more or less drunk today, but as they have drunk up most of the cologne and bay rum they have, in addition to bona fide booze, we do not anticipate any trouble. Well, dearest dearest sweetheart, I must close now to get this letter posted. Another stage of the journey is over, dearest, and we are so much nearer together again. I am anxiously looking forward to letters at Hakodate; I do so want to hear from my dear dear little wife. 


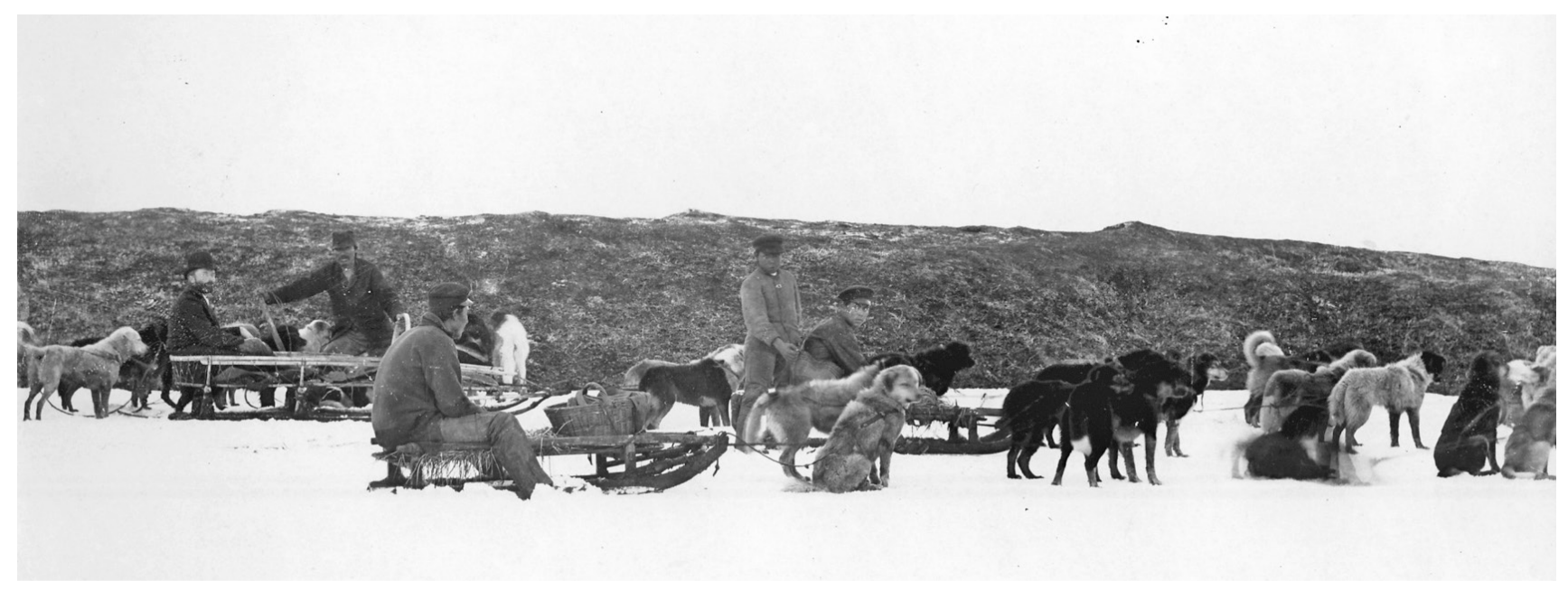

Figure 31.-Bering Island dog sleds. U.S. National Archives.

Lots $\& \underline{\text { lots }} \underline{\&} \underline{\text { lots }} \& \underline{\text { lots }}$ of love and kisses, Austin

\section{Hakodate, Japan}

June 27, 1906

\section{Dearest, dearest wife,}

We left Petropavlovski on June 20, early in the morning, and went south along the coast, past Cape Sopatka, and up into the Okochts [Okhotsk] sea. We took on board at Petrop a hunter named Carlson, who lived on the western shore of Kamchatka and left him there. This is the place where the cod-fishing boats from San Francisco come to fish. We found 3 already there; the "S. N. Castle", the "Diamond", and the "City of Papeete". We went up close to the "Castle", and the skipper talked to the skipper of that craft. She started May 8th from S.F. and had been at anchor where she was 15 days. They had caught already 65,000 fish, and wanted about 300,000 more. I saw the boat fitting out in Frisco before we sailed. She is 3 masted, and carries a crew of 42 , and the captain, $=43$. We sent the doctor over, as they said they had a sick man. One of the crew fell down a hatch and stove in his ribs, and the captain and one other man was sick, too. The captain of the "Diamond" died a couple of weeks ago, and was buried on shore. The mate on the "City of Papeete" also died and was buried on shore. These fishermen must have a hard time going so far to fish, from San Francisco to the coast of China, into a sea notorious for bad weather. I forgot to say we were a night out from Petropavlovski before we passed Cape Sopaka, so we met the "S.N. Castle" on June 21. The sea was smooth, but it was blowing so hard that the ship was heeled way over.

June 22. Went south along the Kuril Islands: the day was absolutely uneventful: we took some hauls with the big trawl, and got some queer fish, and a most enormous crab.

June 23. Arrived at an island called Simushir in the Kurile group early in the morning, and went ashore. This island is much like the Aleutians, with lots of snow on the mountains, and long rank brown grass near the sea. The beach was strewn thick with driftwood, much of it being planks and cut wood, showing that it had come from Japan. I found 2 Japanese beer bottles, and a keg with Jap. letters on it on the beach. There are no trees on the island. One of the mountains is a beautiful volcanic cone, $6,000 \mathrm{ft}$. high, and perfect in shape. It was colder here than in the Aleutians, and we were glad of the driftwood to make a fire with and warm up. We got back to the ship, and stayed here all night.

June 24. left Simushir at 8 a.m. and dredged along the shore, and in the afternoon steered for Hakodate. Nothing special happened all day. Prine got a horrible blowing up from the captain, I don't know what for. I think I wrote you that at Petropavlovski the captain let the men go ashore, and they all came back more or less drunk. Mr. Hepburn and Hazard examined the men as they came aboard and captured 38 bottles of "vodka", or Russian booze. That night Riley (who used to be master-at-arms here, but was reduced because of getting drunk and raising a row at Unalaska to fireman) and another man named Spratler tried to break into the laboratory and swipe some alcohol, so Mr. Hepburn put Teed (the sailor you used to see in the lab.) to sleep in there, with a big iron rod, and instructions to lay out anyone who came in. We had no more trouble after that. Hanson, the sailor who is in the lab. now, got awfully drunk, but went to sleep as soon as he came on board, so didn't cause any trouble. 
June 26. Got warm last night; it began to rain about 10 o'clock, and then turned warm. When it cleared off it was just fine. The sun came out in the p.m. and stayed out, giving us the longest spell of sunny weather since we left Unalaska. Everyone was feeling fine and cheerful. What do you think I bought at Petropavlovski, dearest? I thought we might like a rug for our house, so I bought about the biggest bear skin I ever saw, a perfectly tremendous one, with the whole head and everything, and enormous great claws. I payed [sic] $\$ 7.50$ for it. I'm going to get it tanned in Japan. I was going to get some furs for you, dearest, but there have just been some fur buyers here, and all the best ones have been taken away, so I am going to wait until I get to Hakodate. The bear skin is a beauty, though. At Petropavlovski, Metters, Crater, the Paymaster and the doctor bought great brass samovars, which the Russians use for making tea. They are ugly great things, and would be simply awful to keep bright. We had lots of fun when they brought them back to the ship. Metters says he doesn't know what got into him: he never bought any curios before, but he has all kinds of furs and baskets and everything else this trip. Which he doesn't at all know what he is going to do with. In the afternoon we sighted land, the northern end of the island where Hakodate is.

June 27. Still sunny and warm: the sea since we left Petropavlovski had been as smooth as it could be. We coasted along and got into Hakodate about 11, and dropped anchor near the town. It is a funny looking place from the sea, all little one story houses with weathered wooden roofs. There are lots of steamers and ships in here, but all but one are Japanese, the exception being a Canadian back from Victoria B.C. I am enclosing a couple of souvenir postals from Petropavlovski. I bought the cards at Seattle, and printed them up this morning from negatives belonging to one of the men on board. One is a view of the town of Petropavlovski, and the other is main street, with the hospital steward, Baldwin (on the right) and the ships writer, Arnkil (on the left). Well, dearest, will write again tomorrow.

Lots \& lots \& lots \& lots of love and kisses Austin

\section{Hakodate, Japan} June 27, 1906

Dearest dearest wife,

I never was so glad to get anything as I was to get your 4 dear letters yesterday evening. I had been waiting so long to hear from you, dearest sweetheart. Well, another stage of the journey is over, and we are so much nearer together, darling. It does seem awfully long to me though, and I do get so lonely way out here without my dear little wife, but I promised not to write anything like that and I will keep my promise: only dear, I do so want to see you again, I can hardly wait till next fall. Hakodate is the queerest place: Tongue and I went ashore yesterday p.m. The town is just like pictures of Japanese towns. The houses are mostly 2 story, and wooden, with big shutters, and have a sort of open look. In the busier parts the ground floor is usually a store, with glass in front like a greenhouse, which is slid back when the store is open for business. The stores are purely Japanese: there is a space about 4 feet wide just inside the doors where you can walk, and then there is a platform raised about a foot, and neatly covered with straw matting, where the people stay. You must take your shoes off to step up on it. The goods for sale are arranged in heaps on the floor, and in glass show cases. The people here all (or almost all) dress in Jap. costume: kimonos and broad sashes, both for men and women, only the women have the kimono wrapped about them, while the men they usually gape more or less in the front, exposing the legs clad solely in "lace curtains". They look as if they have been suddenly earthquaked out of their houses when they were half dressed, and only time to put on a bathrobe. The little children are just dear: they wear the kimonos and sashes, the former being made of very vivid and gaudily ornamented materials, as you see in Jap. pictures, and they often carry elaborately decorated sun-shades. They wear, like their elders, wooden shoes made like this

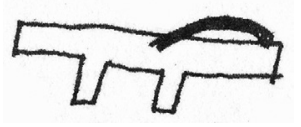

so as to keep their feet clear of the mud. The strap goes on the big toe and another goes on the other toes, the two meeting between the big and other toes. I should think they would be fearfully uncomfortable. People travel about here in "rickshaws", a sort of very small buggy on 2 wheels drawn by a man at a smart trot, although there are horse cars too. Yesterday when Tongue and I went ashore the launch towed in the whaleboat full of "liberty" men, that is sailors on leave. They had 2 days off. We had not gone far when we heard a great clatter, and saw the cockswain of the cutter, a sailor named Alvine, and old Jacobson coming along at a great rate in rickshaws, followed by several others. Later on we passed a place where beer was sold, and seeing a great crowd looking in and smiling, and a number of rickshaws lined up outside, were not surprised to behold Alvine and Jacobson standing up at the bar offering drinks to all comers. But a greater surprise was in store today.

\section{Hakodate, Japan \\ June 30, 1906}

Dearest Dearest sweetheart,

I just received your dear picture in your wedding dress today. I think it is just as dear and sweet as it can be; the only trouble is that it isn't nearly so pretty as the original. I am sending you some picture postals with this dear- 
est, to put in the album you said you thought of getting. They aren't very pretty but you see Hakodate is only a little place, and the demand for such things is very small, so they don't have any good ones. What do you think of the moustached Ainu women? The Ainus live way up in the northern part of this island, and are the primitive people of this part of the country. They belong to the Aryan race with the white people and the Indian coolies, and not with the Mongolians as do the Japs and Chinese. No one knows how they got here. The picture of the high school shows how much education is thought of in Japan. I had my hair cut yesterday on shore, in a native barber shop, with RARBER in big letters on the Japanese characters on the sign. No one knew any English there, but I got it done all right. After cutting it they squirted some oil on it out of an atomizer, and instead of wetting it to comb it rubbed a stick of grease like a stick of shaving soap all over it. It made my head smell like a whole perfumery establishment, and it will take about a month of diligent work to get the grease and stuff off. I wonder what you will say when you see my whiskers? I have grown a little peaky beard like Mr. Seward's. Mr. Hepburn and the surgeon have too. I forgot to say I am sending with this a child's picture book in Japanese. You will notice it opens from the back and there is a native picture postal card just inside the back cover; but the funniest thing is in the 5th page (counting from the back cover); do you recognize one old friend "Foxy Grandpa"? Near the front of the book you will see some pictures of things, giving the English names, which are rather amusing. I bought a pair of little mantel vases yesterday darling which I hope you will like: they are about 6 inches high and very prettily ornamented. I also got a little open-work bon-bon dish. They didn't cost much, and are quite pretty and odd. I paid 80 cents for the vases and $\$ 1.25$ for the bon-bon dish. I never saw any like them before. The officers have all chipped in and hired a sampan or row boat, so we can go in whenever we want. To distinguish our boat from all the others at the landing place, we have a special flag which Prine made after a design of Mr. Hepburn's, which serves the purpose well, and is the envy of all other sampan men. The design is a conventionalized octopus, with the arms twining gracefully around each other, and with little green tassels with red centers for eyes. The octopus is white on a red field. It is about 11 o'clock now dearest and I shall have to close as the lights go out in a few minutes, so good night dearest dearest wife, pleasant dreams and duck's rest, dear.

July 1. Sunday: you can always tell Sunday on board, because we always have beans for dinner, although once they made a mistake and we got them on Monday instead. I am afraid I have got more or less mixed up on dates in many of my letters, dear, but I am straightened out now at least temporarily. Well, June is over, so we are so much nearer again, darling. I never knew time to go so slow as it has since we have been here. If we are at sea and working all the time, it is not so bad, but if I am not busy all the time, I do get so lonely feeling and homesick, dear little wife, but I promised I wouldn't write anything about it, so I won't. I sent a postal card and wrote a letter both to your mother and to Betty this morning, to sort of let them know I was still kicking. I enclose something which I discovered a little while ago. I intended to use it myself, but I decided that the sun here was not strong enough to materially damage my complection [sic], so I am returning it. Yesterday we were treated to a surprise: all the sailors who were given shore leave came back on time, and all sober enough to stand up: this almost constitutes a record for the ship. Practically all the men spent their entire pay since leaving San Francisco, and some borrowed considerable extra. They returned in great spirits. I am glad they were given leave for so long ( 2 days) because they haven't been allowed off the ship since before the earthquake and were getting rather discontented and morose. When you come to think of it, two months confinement on a little ship like this must get monotonous, without even touching land, more especially when we have called in at a number of places. The excellent behavior of the men on shore, together with the prompt return of everybody, clean and sober, will probably mean that their leave will now be much more frequent, which will result in a far more willing and efficient crew. You see, a sailor needs a rousing drunk every so often, or he gets morose; but if he gets good and full, it seems to clear the cobwebs off of his intellect, and he is about twice as efficient, until the time comes around for him to have another time. Sailors are queer beings. I got a posted from Knowles of Fiji yesterday. It was evidently written just after he had heard of the earthquake. I enclose it herewith. That chap, Cecil N. Rice, of Grenada, is chief clerk in the governor's office in Grenada: he is awfully nice; you remember you enclosed a letter from him? Nothing exciting has happened lately. Last night, the doctor bought a funny iron ring, with gold dragons chasing each other around it, and exhibited it at the dining room table. Everyone made remarks about it, Crater claiming that he had swiped it off of the steam-launch engine, and that it had begun its career as a whaler on a steam pipe, and Metters that he had sawed the end off of a gas pipe and painted the dragons on himself. The doctor did not like the lack of appreciation for his rare work of art a bit. Toward the end of supper, he tried to find out who had it, but nobody owned up. He made the remark that he would fix the "swivel-eyed pelican" who stole his ring when he caught him. The "swivel-eyed pelican," however proved to be Professor Snyder, who had been examining it, and, I suppose, forgotten it, and had it in his napkin ring. The doctor relented, and didn't "fix" him. Well, dearest, dearest little wife, I must close now to get this letter into the Yokohama mail so good-bye, darling. I shall write again tomorrow.

From your most loving husband. 
P.S. The article I was going to enclose was a vail [sic], but I just happened to think, dearest, that if I put it in, they would stop the letter at the custom house, and it would be a job to get it out, so I shall bring it to you when I return.

Lots \& lots \& lots \& lots of love and kisses, dearest, and duck's rest.

Austin

\section{Mororan, Japan \\ July 6, 1906}

Dearest, dearest Sweetheart,

We came here yesterday p.m. (that is we arrived here yesterday p.m.) for coal. It is about 90 miles from Hakodate. We are going back early tomorrow morning, and expect to find Dr. Gilbert waiting for us. I have a nice present for you, dearest: what do you suppose? I got 3 of the prettiest cross fox skins you ever saw in Hakodate to make you a set of furs. Two of them match exactly: I never saw two animals more alike, and the other is much thicker fur, and a little grayer. The two just alike are for a boa, (they have lovely great tails) and the other for a muff. The cross fox is at home one of the most valuable furs, and is about the most expensive out here. Up in the Aleutians most of the people on the boat bought "blue" fox skins. The blue fox is a fine bluish gray all over, but unfortunately it fades. The fur is very thick, and very fine. I priced some blue fox at Unalaska, and they ranged from $\$ 10$ to $\$ 18$ for good skins. The cross foxes are about the same. Most of the people bought the blue fox at Atka and Attu, and got them in exchange for old clothes, shot and all sorts of things, the average price being about $\$ 7$. I happened to be away hunting all the time we were in both places, so didn't have a chance to get any: it turned out it was rather lucky: I told you about the doctor and the dead skins, didn't I? Well, he took a lot of skins to be tanned the other day, and when they were tanned, they had great bare spots on them where the hair had come out, He is quite touchy about it: he did get awfully stuck. None of the other skins are much better. The cross foxes I bought are all beautifully tanned, and are the prettiest I ever saw. This picture is to give you an

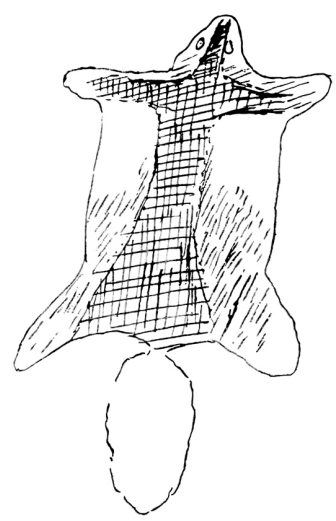
idea of the color. The parts with the crisscross lines is black. The shaded part (on the flanks black, but the hairs are tipped with white, so it looks gray. The unshaded part is reddish, like a red fox, only a prettier red. It shades into the gray behind, gradually. I do hope you will like it, dearest; it ought to be mighty pretty made up, and it is pretty expensive in the east. I paid $\$ 23$ for 3 skins, which they tell me is very cheap for such good skins, even here. The other skin which I said was thicker is darker gray, and a little lighter on the sides. It will make a lovely muff, but is much too thick for a boa. I sent our bearskin ashore at Hakodate, darling, to be tanned and fixed up. It will take a month. We are going to get it when we come here again, or have it sent to Tokyo if we don't come back here. It is a dandy skin with whopping big claws. The fur is nice and thick all over and not thin on the sides as most bears are. By the way, there is a steamer at Hakodate whose owner has a wooly tiger on board. You remember Ned Holmes said he wanted a wooly tiger skin. This tiger has hair 3 inches long, but isn't very prettily marked. It is a tremendous big one though.

I went ashore this p.m. and got a set of 3 gongs on a string; the kind they use so much for dinner gongs nowadays. They are hammered brass, and very sweet toned. I thought we would need them, and I might as well get them. Do you think I am too extravagant, dearest? Those foxes will bring at least $\$ 50$ each at home. I will write again tomorrow, dearest wife.

Lots \& lots \& lots more love \& kisses from Your loving husband

Hakodate, Japan

July 7, 1906

Dearest, dearest wife,

We are returning to Hakodate from Mororan to pick up Dr. Gilbert and another Stanford professor, Dr. Heath. I don't know where we are going after that, dearest, but you had better address your letters to care USS Albatross, San Francisco, and they will be forwarded. We coaled at Mororan quicker than the ship ever coaled before; the Japs began at 6 in the morning and were all through it at 8: it took 2 days at Unalaska. Mororan is a dirty little place, purely Japanese, with no foreigners. Its only importance is that is so near the coal mines. I never saw such a bustling place as Hakodate for its size; steamers coming in and leaving all the time. Practically all the steamers in this part of the world are Japanese: if things keep on they will soon control the trade of the Pacific. They run live to Australia, New Zealand, the Phillipines [sic], Hong Kong, San Francisco, Tacoma, and Canada, besides their Coral and Chinese trade. Do you remember seeing the "America Maru" coming into S.F.? I pointed it out to you because it was flying the Jap. flags, a white flag with a big red sun on it. I told you yesterday about finding a nice wooly tiger skin: I forgot to say the price was $\$ 1200$ gold. It was not tanned or anything. That is quite cheap for them, even out here. The climate here is cool and comfortable: it seemed warm after the Aleutians and Siberia, but since we have stayed here a while, it does not seem so warm. I wrote you that it was warm and sunny: well, the day after I wrote it started in to rain and has been cloudy or rainy ever since, but the sun has just come out again within half an hour. Nothing of in- 
terest has happened lately: Crater, Metters, and the doctor, and Dr. Torrey went ashore last night, and came back about 2 this a.m. Crater was slightly the worse for wear, but was all right this morning. I am writing on Japanese paper. It is the thickest I could get, but it is rather hard to write on. The Japs paint their letters on it with a fine brush dipped in India ink. If we go to Kobe, dearest, I am going to get you a tea set. They make them there to order, and make the finest in the world. They have a book of designs, and you pick out the one you want. They will put a monogram or anything on it too, and I am going to get one and have your monogram on all the pieces, dearest. I only hope I strike a design that you will like. I shall try my best. The doctor was ashore yesterday, and bought a lot of truck. He has enough now to stock a good sized curio shop: every drawer and cupboard in his room is jam full, and he has a lot in the dispensary too. The rest of us joke him about it: we tell him he is preparing for another fire. Dr. Torrey has become infected with a mania for collecting useless junk too, and is borrowing all the money he can, as he can't get any on board, because he didn't bring his orders with him when he joined the ship. Well, dearest, good bye for the present, and "duck's rest" I will write again just as soon as I get a chance.

Barrels \& barrels of love,

Austin

Hakodate, Japan

July 7, 1906

Dearest, dearest Mary,

I have just received your dear letters of May 30-June2, and I was just awfully glad to get them. I am glad too, dearest, that you are not in California, because it must be just horrid now. We hear that they have had several earthquakes lately, and there are strikes in San Francisco. We have heard also that there are hard times in the east. You said, dearest, you had sent a card telling me where you would be at different times in Europe. It hasn't arrived yet, dearest. If it is a postal, it has stuck at San Francisco, as they don't forward them, only letters. I am glad that you are so cheerful, dearest, we will try and keep up our courage till we meet again, won't we? I never was half so homesick, dearest dearest wife, as I have been since I have been in Hakodate. I would come back right off if I could, dear. I wrote to Dr. Evermann, dearest, and told him I had lots of birds and wanted to come to Washington as soon as we got back to work them up. I expect to get a letter back in a few weeks. I will be awfully glad to get another picture of you, dearest. I think it is awfully sweet of you to send me one. Everything is the same here, dearest, and nothing worth mentioning has happened. Well, goodnight, dear dear wife, I must close now, for I hear the dynamo beginning to slow down.
July 8. Dear dear dear wife: we just got a telegram saying that Dr. Gilbert is up at Mororan: he came up here to catch the boat. But found we had left, so went to Mororan to catch us, and must have passed us coming down: he will be here tomorrow. Nothing of interest has happened, dearest. Tongue and I went for a walk this P.M. all over town. Metters went ashore last night and got horribly full, so he was just able to get aboard this morning. He is full again tonight, down in the ward room. I do miss you so, dearest, and I have been $\underline{\text { so }}$ homesick since we have been here: it isn't so bad out at sea where we are working all the time, but it is just awful to be lying in port with nothing special to do, darling. I found out today, dearest, that we will be back in San Francisco on October 31 at the very latest; probably in the latter part of October. It seems an awfully long wait, dearest, but I am glad to know a definite date at last. Dr. Gilbert has to be back there for his classes. I am almost the only person on board who got any mail so far, dear wife: you see I told you to address "Hakodate", so the letters came through all right: the others had theirs addressed San Francisco, expecting they would be forwarded. Well, the mail was forwarded to Yokohama and the postmaster there, hearing the Albatross had gone to Nickolov [Nikolayevsk-on-Amur] on the Amoor [sic] River, forwarded it all there. We just discovered it today, and cabled to Vladivostok to have it sent back, and also telegraphed to Kobe and Nagasaki to head it off if it hadn't left. It will be all right to address "care USS Albatross, San Francisco" after this, darling, because they will be more careful after having made one mistake. You see a Russian boat "Albatros" left Hakodate for Nicolov just before we came and they thought the mail was for her. It has been sunny and warm today. Hakodate is not supposed to have a very nice climate, but it has been a very welcome change from the northern places, and it has been sunny most of the time. Good night and "duck's rest", my own dear, dear little wife. One more day has gone and we are so much nearer together.

July 9. Dear dear dear wife, I have just received your letters of June 4-8, and was just awfully glad to get them. I do hope I get your picture all right, darling. I ought to, as I got the other one all right. Isn't it too bad about Betty's dresses/ I really sympathize with her. I wonder what she would do on the Albatross with a couple of months between laundries? When we get together again, darling, we won't be separated anymore, will we? We ought to be able to arrange it some way. I didn't realize it would be so hard. I didn't know I could be so homesick and horrid feeling as I have, dearest. I am glad you are going to have a doctor and nurse in your party, dear. I feel so much safer about you now. You will be awfully careful, won't you?

Every once in a while I get horribly afraid something will happen to you, dear. Dearest Mary, won't you please write what it is about Lawrence? You see nobody will ever see any of your letters, and it would make me feel so much 
better, dearest. You see, darling, I don't mean to be inquisitive, but when a person is as homesick and sort of miserable as I am, every little thing like that, something concerning his wife dear, especially when his wife means as much to him as you do to me, sort of galls on him like lead. Please tell me dear. I hope it isn't mean of me to ask, but I feel sort of forlorn and helpless way out here: I never felt half so bad before. Anyway, I know my precious little darling will be very careful, anyway. Anything that happens, dearest, I do wish you would write me, so I could know right away. I don't mean to worry, darling, but you see when I feel so forlorn as I do now, it makes things so different, especially when I am way out in Japan. I didn't mean to be so gloomy, dearest, but I sort of couldn't help it, and I won't again. Forgive me, dear wife. I am glad pa is so nice to you. You see how much he thinks of you, darling. So you are off for Europe at last! Well, dearest wifey, I do hope you have a good time. I know you will see lots of interesting things. Won't we have lots to tell each other when we get back. Dr. Gilbert got back from Mororan this morning, with Sindo, the Jap. They had a great time in Tokio [Tokyo]. We are going to stay here a while longer, and are then going to Nagasaki. Well, good night and ducks' rest, precious, precious wife. I shall write again tomorrow. Give my love to Betty and your mother. I always mean to send it but always forget it. I am sorry this is a sort of gloomy letter dear; I will try to be cheerful in future.

Heaps \& heaps \& heaps of love and kisses

From your own loving husband

P.S. This Japanese paper is simply vile to write on.

Hakodate, Japan
July 10, 1906

Dearest, dearest sweetheart,

I must apologize for the letter I wrote yesterday, asking about L. After I wrote it I felt that I shouldn't have done it and tried to get it back from the P.O., but I couldn't make them understand what I wanted. Please forgive me for writing that way, darling; you see I feel kind of anxious about you and so much want to see you again; and am so sort of forlorn and homesick dearest that I got sort of upset. I know I was foolish, dear Mary; will you forgive me, dearest? We are still in Hakodate. Dr. Gilbert and Sindo got back to the ship yesterday morning, bringing with them Dr. Heath, of Stanford, who seems very nice. I think the Mr. Sweed you said Henry talked about, dear, is Mr. Snyder, who is on the boat with me. Well, you know Dr. Gilbert went down to Tokyo to find out about our getting permission to collect fishes in Japan. Complications seem to have arisen. You see there are very few ports in Japan where a foreign warship can call in, as they don't want foreigners to know too much about their harbor defenses [sic], etc.
Although the Albatross is not a warship, all her crew are navy men, which amounts to the same thing, as they might make plans of the various fortifications. We wanted to do some dredging in the "Inland Sea", and in the sea of Japan. Now most of their closed ports are on those seas. The Jap. government says we can't dredge in the inland sea, or sail about in the sea of Japan because of the danger from floating mines. You see, during the Russo-Jap war, both sides dumped into the sea hundreds of iron buoys filled with dynamite, which explode when a ship hits them: the Japs let loose 700, and the Russians probably as many of which only 100 have been located since. A large number of ships have been lost through striking these mines since the war, one only last week; and Japanese ships are only allowed to cruise about in the Japan Sea in the day time: they must go into port at night. As the Japan Sea ports are closed to foreigners, we should have to keep at sea all the time, which would mean more or less danger to ourselves; the Japs do not want the responsibility of letting the Albatross risk herself like that, as her loss would be liable to endanger the good-will of the U.S.: therefore, we have got to keep away. There is a lot of sense in what they say: I think myself it was sort of foolish to come all this distance without first having got the necessary permission to work, don't you? Suppose a Jap. steamer came suddenly into Boston, or say Salem (which is very like Hakodate), and asked permission to run about and dredge in Beverly and Manchester, and all along the coast without warning: I'll bet it would have hard work getting permission from Washington. The doctor seems to have a regular mania for buying things: he comes aboard everyday with all sorts of battered up old brass work: which any self-respecting junk man would scorn. His cabin is chock full: all the drawers and his desk are as full as they can hold and he has a set of temporary shelves, all full too. He has a couple of boxes full of stuff in the dispensary (to the great disgust of the hospital steward, and 3 barrels more in the lower lab., which Mr. Hepburn is going to ask him to remove. One of his last purchases was a great toy junk; (a funny Chinese boat, you know) about 4 feet long. Dr. Torrey has become infected with the mania too, and his purchases are even more weird. Yesterday he got two great kettle-hangers about $6 \mathrm{ft}$. long, a jinrickshaw lamp, and a couple of old cast iron kettles, one with a newly made bronze cover. The others have great fun over these two, referring to all the stuff they got as "loot" or "plunder". We are having a chess tournament now: there are 4 of us who play chess: Tongue, Hepburn, Torrey and myself. We each play 3 games with each of the others. Tongue is now ahead, and I am second. All the hotels here have printed cards which are sent on board as soon as a boat comes in. Some of them are rather funny. I enclose two samples: you will see one of the proprietors tried to be facetious. Besides these cards, there are lots of "washermen" who come aboard and give you cards, too. I sent you a couple of postals yesterday, dearest, did you get them? They are the same blue postals I sent you before, taken at Pet- 
ropavlovski. No photos can be taken here, as it is a fortified town, and they are afraid that foreigners would get an idea of the ports, etc. Dr. Torrey took one from the steamer the day we came in, and got jumped on by the skipper for it. These Japs. are the funniest people: I didn't have much of an idea of them when I started: in fact most of the people on the ship are more or less prejudiced against them, and in all are much more now. The main part of the town, where most of the ships are, is fairly clean, in fact quite so; but a couple of days ago, as I wrote you, dearest, Tongue and I took a walk through the outskirts where foreigners do not go (I mean the foreigners who reside here and do business here), and where, therefore it is purely Japanese. The houses are all low (2 stories) cheap wooden structures, almost all with stones on the ground floor, with sliding glass doors in front making the lower part of the house look like a conservatory. None of the houses are painted, all being the color of old weathered wood. Many of the roofs are held on by heavy rocks. A characteristic aroma of half dried, half-rotten fish, together with quite an assortment of other odors pervades the whole place. The habits of the people are quite disgusting: worse than anything in Europe. We came back in a horse car, drawn by 2 little shaggy Jap. ponies. The car was on a scale with the size of people, and consequently we were considerable of a misfit. I am not particularly large, but I had to stoop to get in and get out, and Tongue nearly reached up to the roof. It was shorter than the funny little cars we used to go to church in S.F., and not nearly so high, nor so wide. The fare is 2 sen or 1 cent. It's funny but there seems to be a general idea that Japan intends to pick a fight with the U.S. The Japs are certainly busy doing all sorts of things, but if they even got into a war it would be the end of them, as they are very poor and are taxed about as much as they can stand now. Anyhow dearest, there isn't any chance of a war for several years yet, till they get over the effects of their last tussle with Russia. I have just been looking at the furs I bought, darling, imagining how they will look on my precious little wife. I do hope you will like them, dear. Anyhow, they are much better furs than could be got at home for many times what I paid. One bear skin is being tanned, dearest; it ought to be just a beauty when it is done. One man up in Petropaulski had some dandy sables, dear: I wanted awfully to get some for you, but he wanted $\$ 50$ a piece for them, and it takes 3 to make a muff and a boa, just a little high, wasn't it, dear?

Yesterday a Jap. gunboat came in here and anchored near us, I suppose to watch what we did. These are the greatest people for looking out. If you go ashore to stop at a hotel, your name and all about you is immediately sent to the police, and they keep a strict watch on you until they find out you are harmless; they are terribly afraid of foreign spies. The trouble with this boat is that she has a navy crew, and therefore in their eyes is a warship, and will bear watching in consequence. I expect we will stay here in Hakodate until we find out from Tokio whether we can do any collect- ing or not: it may be several days yet. I am mighty glad for it for one thing, darling: it allows me to send off a letter every day to my precious, precious little sweetheart. It does seem something like talking to you to write you a letter every day, dearest. If you only knew how I long to see you, Mary, darling. Do you know when the Ropeses are staying in Berkeley, dear? If you do, please let me know and then at the end of the summer you can come out there, darling, and I will know where to meet you. I just must see you, dearest, just as soon as we get back. I shall cable you from Honolulu when we get there, dear. Sometimes it just seems as if I couldn't wait for the summer to go, it seems so awfully long. I always mean to be cheerful in my letters, dearest, but if I am sort of gloomy sometimes, please forgive me, darling. You know what you mean to me, precious, and you sort of mean more and more and more all the time, and I do get so awfully homesick to see you sometimes, but I will try not to show it any more in my letters. Dearest, when we meet again, we will never be separated any more, will we? We will just be together all the time, and we will be the happiest people in the whole world, won't we. I am going to get some odds and ends at our house at Yokohama, dearest: there are no really decent things here, as it is in a little place and purely Japanese. Did I tell you that I was going to get a teaset when we get to Kobe, dear? I am going to get just the prettiest I can find, made to order, with your monogram on it. I do hope you will like it, dear. Well, dearest, dearest wife, good night; God bless you, precious darling, and duck's rest.

From your most loving

\section{Austin}

P.S. If you only knew how I long to kiss you, dearest.

Hakodate, Japan

July 11, 1906

Dearest, dearest Mary,

We are still here, waiting patiently for permission to collect things. Mr. Snyder and Sindo left last night. They are going to stay on shore and catch fish along the coast and in the lakes and rivers. We are going to pick them up just before going home at Nagasaki. They have been painting the ship all over the last few days, and she looks fine now. Almost everybody has walked into the paint a few times except me. One of the firemen was brought on board yesterday by a trio of policemen; he got drunk, and got into a fight, and was promptly captured. The day before another fireman got hurt in a fight on shore, and was brought on board by 4 policemen. He made a great row on the wharf saying he was a "free born American, he was," and calling the Japs all kinds of names. He is a huge six footer, and the Jap police are all small, and he looked awfully funny. Most of the men who have been ashore however have behaved themselves. I have just now been handed 
a letter from you, dearest, which has just come on board; somehow I just never was so glad to get one before, dear. It is the letter you mailed the 14th of May I suppose everybody looks on you as quite a prodigy now, precious sweetheart, since we came through all that earthquake business. I think it is a good scheme for you to go up to Whiteface, if I am not back when you get home, as I think time would pass quicker up there, dear, than in a place like Newtonville where everything is always the same. You see up at Whiteface everything will be new and I think time would pass sort of quicker, dear. You say you get lonesome, dearest: I don't see how you can get as lonesome and forlorn and homesick as I do, dearest: sometimes I think I just can't bear it, and must come right back. I never felt half so sort of dismal before, darling. When we get together again dear, we will arrange some way so we just can't be separated again, won't we? I am awfully sorry you got hurt at the dentist, dear: I wish I could take all the pain out of your life dear little girl; I would be so glad to put up with it all to save you from any, it would seem almost a pleasure the worse I got hurt. I just hate to think of my precious little sweetheart getting hurt at all. You say you are going to limit yourself to $\$ 25$, dearest, abroad: I shouldn't think that would be nearly enough. When I get to Yokohama I shall send some money home for you, dearest. I will send it to pa to keep for you, so you can get it as soon as you get back. I shall send more every chance I get. Don't feel limited, dearest, spend all you want to and have a good time. I don't have anything to spend it for, darling, except once in a while I get something for our house, or for my dear dear wife. I stay on this ship most of the time. Have the best time you can, darling, and you spend the money for both of us, won't you, dear. I appreciate lots more things you buy for our house than things I buy myself. I'm glad the Ropeses are staying in Berkeley, because when you come west again in the fall there will be some place for you to come to dear, where I can meet you. What is their address, darling, so I will know just where to come? We will have to arrange some camping when we are together again, won't we, darling? Won't it be fun. Perhaps I can get 10 days leave before we go to Washington, and we can go up into the Rockies. Wouldn't that be great? Well, dearest, dearest wife, good night, and God bless you, precious. "Duck's rest", darling.

Lots \& lots \& lots of love and kisses

From your most loving husband

Hakodate, Japan

July 12, 1906

Dearest, dearest Sweetheart,

Still here, but I understand we are going out on Monday to Nagasaki: We had more or less excitement last night: just after supper we discovered a fire in the town, in one of the thickest built up districts. It grew rapidly into a huge blaze, lighting up the whole harbor. These flimsy wooden houses burn like tinder when they catch. After burning a couple of hours, the flames died down, and by 10 o'clock had pretty well died out. It burned up about a block. It has been hot today: this first really hot day we have had. We got word today from Yokohama that there are 215 letters in Yok. stuck there for unpaid postage. The postage due amounts to 22 yen, or $\$ 11$. The capt. immediately sent down $\$ 25$ to the consul, and told him to have all the letters sent on, and also all others which might come. I expect to get some from you, darling, in the lot. I don't mean that you have sent any with 2 cent stamps, but they often hold up letters with 5 cent stamps by mistake. We have heard that everything is all right for collecting here, except a few formalities in the war department about entering fortified ports: you see foreign ships are always excluded from certain ports in every country, so as to give that country a base for naval operations in case of war, which only they themselves know, and into which their ships cannot be followed. Mr. Hepburn and I went ashore this p.m., and took a walk around the park. There is a playground there with all sorts of swings and things and a funny log arrangement I never saw any where else. It is a log about 40 feet long and a foot and a half thick, hung by a couple of chains on each end to 2 supports, like this picture. You get this log swinging back and forth(the ends going through under the cross bars) and then try to walk along it. The little Jap. boys are adept at it, and it looked so easy we thought we would try it.

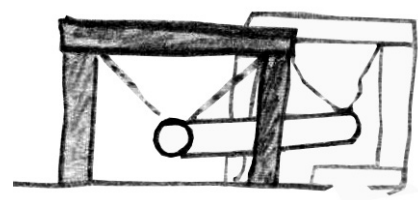

I never saw anything that would slide your feet out from under you as quickly: we had great fun trying to walk on it. The funniest thing was when we first got there. The playground is in a kind of hollow, and it was hot, we went up on a sort of hill to one side to rest a little. We were somewhat surprised to find Metters and Prine there. We talked with them a few minutes, and then, who should appear walking down toward the log but old Jacobson (do you remember him, one of the sailors as you know), just drunk enough to be game for anything. He watched the Jap boys for a while, then cleared them all off and offered prizes to anybody who would go the whole length of it when it was swinging fast. A lot of them tried, but only one stuck all the way across. Jacobson gave him a piece of money, and then they tried again. We saw him distributing coins (we wondered where he got them, as he had spent every cent one day ashore last week), and then, unfortunately, he caught sight of us, and walked away. We would have given lots to have seen him try it himself. Poor old Jacobson is one of the characters of this ship. He has been on here 22 
years, and is by far the best sailor on board. He knows all about nets, and the most useful man generally in the whole crew. He was a very smart boy when he came here, and worked his way up through several grades to chief boatswain's mate. (Metters and Prine are only one grade higher.) Unfortunately his liking for liquid refreshment was too strong for him, and he went down again, grade by grade, until now he is just where he started, 22 years ago. Everybody on board has a tender spot for poor old "Jake", and he is a general favorite everywhere. He is by far the most efficient man on the ship, and if there is anything to be done, you will be sure to find him the first one to do it. At sea he is all that could be desired; but in port he is usually, in fact always, more or less full. Whiskey, cologne, bay rum, alcohol, shellac, or boot blackening are all the same to him. (You would be surprised to see how full a man can get on liquid shoe polish): Another of our characters is old Larsen, the chief quartermaster. He also has been here 22 years and is now about 60 years old. He is a big Swede, a finely built man, although getting rather old now. The 2nd Quartermaster, Olsen is also one of the old timers. There is continuous war between Olsen and Larsen: they are horribly jealous of each other, the more so as Olsen used to rank above Larsen, while now their positions are reversed. Metters says when he first joined this ship, Larsen cornered him and told him to especially look out for that "old fool" Olsen; that he was an awful bungler and didn't know his business any more than an old jack rabbit. Larsen had hardly got out of sight, when Olsen appeared, and told him to above all things beware of "that man" Larsen: that he didn't know enough to keep himself over night. That is the way it goes: they are always at each other: every few days one of the officers has some fresh anecdote to relate about them. A while ago, Mr. Hepburn was called forward just at lunch time, and found Olsen standing holding his nose, with a plate of corned beef in his other hand. He was protesting strongly about being served such food. "Why, sir" he said "its-its vicious." Mr. Hepburn said it is just the same as the officers were eating and even better but that didn't appease him; so Mr. H. sent for a plate of our corned beef (We happened to have it that day), and told Olsen to try it. While Olsen's back was turned, he dexterously changed the 2 messes of corned beef on the plates, so that the officers corned beef was on Olsen's plate (the crew used white plates, and the officers plates with blue designs on them). Olsen sat down and ate some of the beef from the officer's plate, and had to confess the crew's meat was the better. He backed down and apologized, and we haven't heard anything more from the crew on the subject of corned beef since. That episode earned for Olsen the name of "Old Vicious" by which name he is always referred to in the ward room. Well, dearest darling, I am afraid I am boring you with these tales; you see they have an exaggerated interest to us on board ship, because there is nothing else interesting happening. We are all well on board, and getting on fine, dearest, dearest Mary. Thank God another day is gone, and we are so much nearer together again, dear wife. We'll keep up our spirits, won't we darling? Won't it be just the happiest and nicest thing that ever happened to us when we meet again, precious? Well, my own dear, dear wife, good night; duck's rest darling.

Lots \& lots \& lots of love, \& heaps of kisses

From your loving husband.

\section{Hakodate, Japan \\ July 13, 1906}

\section{Dearest, dearest, Sweetheart,}

Still here, but going to get out in a day or two. It gets to be pretty dull hanging about an uninteresting place like this so long. It is getting warmer now, almost warm enough to wear white clothes. Everything is peaceful, darling, only it makes me feel awfully sort of lonesome doing nothing: it isn't so bad if we are working all the time, darling, because time goes so much quicker: but it drags terribly when we are just loafing. But I promised not to write about it any more, didn't I, dearest? Dr. Torrey has succeeded in making himself uniformly unpopular on board. He is supposed to take care of all the invertebrates collected on this trip, and to get all he can. The way he has done it is to go chasing about with the doctor whenever we have been in port, and wasting all his time. He doesn't do anything when he is on board, either, but sort of moon around. He has achieved a fine reputation as a loafer all around. The funniest part of it is that the other day at supper he was telling us the sorrows of a teacher. He said, he, for one, got no vacation at all; in the winter he had his classes, and in the summer he was doing research work all the time. He said that about 3 years ago he simply couldn't stand the strain, and came down with typhoid. There was an awful grin went around, sort of suggesting that the only strain he had to worry about was the strain of having nothing to do, and not doing it. Even the skipper noticed that he has done nothing so far. He is the most confirmed loafer I have seen in a long while. When we are in port, he spends all his time hunting curios on shore, and never collects a thing. He acts in the lab as if he owns the place, and bosses poor Hanson (the sailor in there) about as if he were a slave. He is supposed to tell me if he wants Hanson to do anything, but he never does. Hanson hates him, and I expect they will have a row some of these days. It is so funny, dear, at sea when a few people are shut up together for a long while, their true characters shine out; they can't hide them very long. The party on board now is the most harmonious they ever had, I am told: everybody is pleasant and nice (with the single exception of Dr. T., and he is always sweet to me), and we get on fine; in fact, we couldn't get on better. Well, darling, good night, and "duck's rest", precious sweetheart.

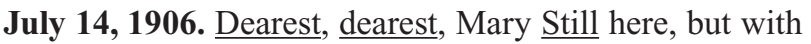
more definite prospects of leaving. We are going to Nanao, 
on the west coast of Nippon Island. Everything is about the same, dearest. Tongue and I went ashore this evening and found a sort of fair going on: on each side of the main business street (which runs parallel to the water front; one block inland) there was a long row of little booths lit up by Jap. lanterns and lamps where they were selling all sorts of things, especially children's toys and small wares. There were lots of stands with formidable looking tasteless things to eat, mainly pink and white marshmallow looking cakes made out of rice paste, and in other places there were lots of potted plants neatly arranged in rows. It was very attractive. There were crowds of people out: in fact everybody seemed to be there. After strolling about for a while, we were just about to go back to the ship when it occurred to us that probably the doctor and Torrey would be somewhere in the crowd, as we knew they were on shore, and would probably be attracted by the chance to pick up a little more junk. We looked the crowd over carefully, and sure enough, there they were, Torrey with a great bunch of straw matting under one arm and big bundle under the other, and the doctor with a couple of big bundles, looking at an exhibit of bronzes. We nearly died laughing, and then we skipped away so they wouldn't see us. I have seen people daffy over curios before, but never quite so bad. Well, dearest, dearest wife, good night. One more day has passed, thank God, and we are so much nearer together again, dear.

July 14. Dearest precious little wife, still here, but going out early tomorrow morning to Nanao. It will take us about 3 days to get there. The mail that I wrote you that had been sent up the Amur River will be there, and also a lot of netting from S.F. It will be mighty nice to be at sea for a few days again after this long spell (19 days) in port with nothing to do. I was going to have my photo taken here, dearest, but there were no decent places, so I shall have to wait until we get further south. Hakodate is only a little small place, comparatively. There are plenty of people, but they are all Japs, with purely Jap customs. You would hardly know me, Mary dearest. I have grown quite a respectable beard: one of the pointed ones. It makes me look quite wise. The doctor also has a beard of the same style as mine. Mr. Hepburn has a beard too: you wouldn't know him. They were talking today at the table about uniforms. They have to have lots of different kinds; ordinary dress, full dress, special full dress, white and dress white, besides caps, corked hats, coats, swords, capes, etc. When you add up the whole thing you have quite a considerable sum of money invested. The dress uniform alone costs $\$ 110$. You see the gold lace is awfully expensive, and gets dull quickly, so it has to be replaced often. I am mighty glad I don't have to get them. In some cases where a man is raised from one rank to another the increase in yearly pay isn't enough to pay for the altering of his clothes. Lots of uniforms, too, the officers very seldom wear, such as the especially expensive special full dress. Often such a uniform is kept until it spoils, and never worn, or else a man's rank is raised before he gets a chance to wear it, and he has to get a new one. Almost worse than Betty's dresses, isn't it? It is funny what an assortment of sailors we have on this ship, all enlisted in the U.S. navy. The man who steers the launch is a Pole, Bowolski. Another man who sometimes takes his place, Alvine, is a Swede, as is Hanson, in the lab. Old Jackson is a Norwegian. One, Arnkil, is a Finn, and another, Oskevich, a Russian. Another is a Greek, and there are one or two Germans. Metters is English. Sort of a funny thing to have so many nationalities in our navy, isn't it? It seems to work all right, though: in the war with Spain they were as efficient as if they had all been born in the U.S. I forgot to say that one machinist comes from Rotterdam, in Holland. I am sure I don't know what interest this can have for you darling, all this stuff about things and people on this ship, but there isn't absolutely anything else to write about, dearest. Every day is pretty much like every other on a ship, and nothing particular ever happens. Well, dearest, dearest Mary, I must close now as it is getting late. Good night, sweetheart. I shall try to send this letter off before we go in the morning.

Lots \& lots \& lots of love and heaps of kisses, From your most loving husband

\section{At sea \\ July 16, 1906}

Dearest, dearest Mary,

We left early this morning for Nanao, in the island of Nippon. Hakodate is in the island of Hokkaido, the most northern island. Nippon is the largest and most important island in the whole group. We have been dredging all day, and got a lot of fishes and things: we got an especially big assortment of shells of all kinds, and sea urchins. It has been easy sorting out the stuff in the net today, as the water was nice and warm, and not icy cold as it has been up to now. It has been rather warm today, but not hot. About 6 we ran in shore near a little village and anchored for the night. There are lots of mosquitoes about now, and it is quite warm. I expect everybody will be wearing white suits tomorrow. They are still painting up parts of the ship and putting her in fine order.

July 17. Fine weather: everybody put on white suits today. Hazard had one which was too small for him, which he gave to me. I never saw the sea so smooth as it is today. There is absolutely no motion at all, not even as much as when we were in the dock at San Francisco. It is funny, but the thermometer we sent down on the sounding line registers a lower temperature on the bottom than in Bering Sea, and at less depths. We have been dredging all day, running along in sight of the coast. It is quite warm, but 
not hot. In the P.M. we ran into Sado Island for the night. This is an awfully pretty place, hilly, and partly in fact mostly wooded, with pretty green fields and lots of villages scattered about. It is a small island, but has a population of 150,000 . Some of the oldest gold mines in the world are on this island. There is a fine harbor here. When we came into the harbor we saw dozens of sampans coming out for the evening fishing: the men were entirely naked, except for a breech-clout, and looked mighty little more than savages. The sampans are an unwieldy sort of boat, sculled by a man in the stern with a long oar with a bend in the middle.

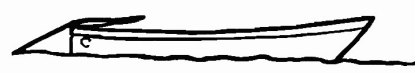

Some sampans have two sculling oars, and some big ones, another pair on outriggers near the stern. The sculling gives the boat a wobbly sort of motion which isn't very pleasant. The people do everything by sculling here, even the big lighters which carry the cargo out to the steamers in the harbor and sculled by 2 enormous long oars over the stern, each oar with a couple of half dressed men working it. All the sampans up here are open but in the south they have been covered over with a little house on them where you can take refuge from the sun. I have less and less use for the Japs all the time. The towns are horrid and smelly, and the men go about rigged as I just described. All the women I have seen have been dressed up all right, just as you see them in pictures, and wearing wooden shoes, which gives them a most ungainly gait. These people must be about as "horrid" as they make them if you can judge from their various works of art. Lots of pretty vases and bronzes and all sorts of ornaments have absolutely the most disgusting things on them and lots of things which otherwise would be just lovely are spoiled that way. It seems to be a feature of Japanese art to be disgustingly vile. Of course you don't see it at home, because it couldn't be imported. Everything is going on finely, dearest, dear-

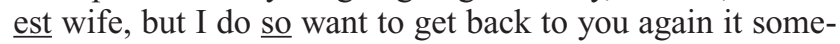
times seem as if I just couldn't wait. Well, precious, goodnight and "duck's rest" darling.

July 18. I have been at sea all day dredging between Sado Island and the large island of Nippon. It has been a glorious day, with the sea as smooth as it was yesterday, and a nice fresh breeze, which kept it from being hot. We all are in white clothes again, and I guess we will wear them for quite a while now. Poor Hazard is sweltering in his thick blue uniform, as he lost all his white clothes in the S.F. fire. You see he was raised to "chief boatswain" just before the fire, which necessitated a change in all his uniforms, and he had sent them to a tailor in S.F. to have them changed, and lost them, He is wearing old ones of Metter's now, but he hasn't any white ones to spare. This has been about the least eventful day of any we have had, dearest, but it has gone quickly, as we have been busy all the time. Well, dearest sweetheart, another day has gone and we are so much nearer together again. Good night dear dear wife.

July 19. We got into Nanao about 10 . It is at the end of a very deep bay. The country coming in is as pretty as I have ever seen. Near the water it is all low hills, some of it pretty flat, a considerable part of it cultivated, and the rest covered with trees. It is just a perfect day, warm and sunny. The country is beautifully fresh looking, and all shades of green. It is about 1 now, and I am finishing up this letter so as to mail it here, as we go out early tomorrow, and I won't get another chance. Well, dearest wife, goodbye until tomorrow. We are going now to Tsuruga.

Lots \& lots \& lots \& lots of love and kisses From your most loving husband

$$
\begin{aligned}
& \text { Nanao, Japan } \\
& \text { July 20, } 1906
\end{aligned}
$$

Dearest, dearest Sweetheart,

We are going away tomorrow morning to Tsuruga. I have just mailed a letter to you from here, dearest, but I had to close it rather hurriedly, so I am writing this sort of as a postscript. We had a great time this P.M. Tongue, Hepburn, Crater, Pinne, Metters, Dr. Torrey, the surgeon and I all went in swimming off the ship. Mr. Hepburn and I swam around the stern and found an empty sampan, whose occupant had come aboard to visit the sailors. We got into it and tried paddling it about with the sculling oar, the way the Japs do. Our success was not startling; we found it was quite an art to make it go at all, to say nothing of making it go fast. It has been hot all day, but there has been a good breeze, and it has been fairly comfortable.

July 21. At sea again, at our old work at dredging. It has been hot with the sea perfectly calm and glassy. Nothing special happened. We got up, ate breakfast, dredged all the A.M., ate lunch, dredged all the P.M., ate dinner, read a little while, and here we are. The busier we are, dearest, the better I like it because it makes the time go so much quicker: it is just awful to hang around in port and do nothing dearest; I do get $\underline{\text { so }}$ homesick then. Well, dearest, it is getting toward the end of July, and then another month will be gone and we will be so much nearer together dear. Sometimes it seems as if I just couldn't wait to see you again, darling. I didn't realize I could miss you so much, precious, or I do believe I should have stayed at the Globe. Well, another day has gone, dearest, dearest, wife. Won't we be happy when we don't have to be separated any more dear? Good night and God bless you, darling wife: pleasant dreams and "duck's rest", dear.

July 22. Another busy day, dredging all day. A funny thing 
happened this A.M. it was Sunday today, and in the first haul we brought up, what should we discover but a Bible! One of the sailors had sneaked it into the net before it went down. Dr. Gilbert has made himself extremely unpopular with the sailors, and they did that to show that it was Sunday and as a delicate hint that they would like a day of rest. However, they had the hardest day they have had for some time. 3 of the men this morning began singing hymns up on the forecastle and got 5 days in the jail on bread and water for it. Another "sassed" Metters and got the same. They are beginning to get a little restless, as they haven't had a chance to get good food and drunk since we left Hakodate. Sailors need a good drunk every two weeks or so to keep in good condition. The doctor has every available spot in his room stowed with curios, and has now begun to look around for new places to stow them. He asked Metters if he had any space and in an unguarded moment Metters said 'yes', with the results that when he turned in at night he found he had turned in on a Chinese Joss house which the doctor had put in his room for him to stow away somewhere. It is funny how the real character of a person keeps showing out, isn't it? Prinne bought a beautiful blue fox at Attu Island, and at Hakodate swapped it for a whole set of furs such as servant girls wear at home: cheap and coarse looking ones, and awful contrast to the blue fox. He thinks he was lucky to get so much for one skin, but I wouldn't give a blue fox for a cartload of such stuff.

July 23. Tsuruga, Japan. We got in here about 5 this P.M. It is a funny little place, purely Japanese. Tongue and I have just been for a stroll ashore. It is a clean town, about a mile long, but narrow. I bought a few little things for our home, precious, a couple of small bronze statues (20 cents each), and 6 or 7 old Jap. sword belts, some of them inlaid in gold. I got them all for 70 cents. We dredged all day before coming in here, but didn't get much: the sailors said it was because we worked on Sunday. We are going out early tomorrow morning, but I don't know where to. It has been hot today, but not bad on deck.

July 24. We have been dredging all day as usual. It was hot, but there was a good breeze all day. We are busy all the time, so the day passed quickly. It was funny, but we hardly got a thing all day. Time after time the net went down and brought up nothing. The sailors were tickled at it, and said it was because we had worked Sunday, and that the Bible had hoodooed it. All the men hate Dr. Gilbert for some reason or other. Yesterday, Mr. Hepburn sent old Jacobson down in the lower lab to help make nets. He just told him I wanted him, but didn't tell him what for, he said he "Warn't no netmaker, he was a seaman, he was" and cleared out. Later he told me he was always glad to make nets for me, but he wouldn't do anything that would help that old son-of-a___ (meaning Dr. Gilbert). That is the attitude of all the men. They will do anything, or work any amount of overtime for me, but refuse to do a thing for Dr. G. if they can possibly avoid it.

July 25. We came into Oki Island today, so I shall have a chance to send this letter off to you, dearest, dearest wife. It won't seem so very long now, before we are together again, will it dear. It is near the end of July now. If you could only realize how I want to see my darling wife again, precious. I am going to plan a honeymoon for when I get back, dearest; don't you think it will be great fun? Won't we have lots to tell each other though. Well, dearest, dearest, dearest wife, au revoir. I shall write you again tomorrow dear.

Heaps \& heaps \& heaps of love and kisses From your loving husband.

July 27. Left Oki Islands last night, and have spent the day at sea dredging. Nothing special happened all day: the sea was perfectly calm, so no one had any excuse for being seasick. Even the Paymaster was up. There is a saying on the ship "up anchor, down paymaster", but it didn't work today. Tongue and I went ashore last evening in Oki, to mail my letter to you, dearest. It is a funny little town, with 3 big temples, which are all lighted up by Jap. lanterns in the evening. The roads leading to them are also lined with rows of lanterns. It was a rather warm evening, and we were rather surprised to see many of the men of the place taking baths in tubs in front of their houses, entirely naked. Imagine it at home, in Newtonville, for example: our worthy friends lined up in tubs along Highland Ave.! A little later, when it began to grow dark, the women began to take their baths in the same way. This was a little too much for me, so I came back to the ship. I hope you don't think me silly, precious wife, but I am trying to do everything just as you would want me to, just as I have always done, sweetheart. I didn't see any of the women bathing, but I saw some of them getting the tubs ready, and knew that that was the custom, so cleared out. Tongue told me afterwards that my fears were realized. Well, dearest, dearest wife good night, and duck's rest, dear.

July 28. Dredging all day again. I have been making up some of the big nets in use from netting we got at Nanao. I never saw one made before, but I have had pretty good luck putting them together. My man Hanson is a fine netmaker, and can stitch nets together and mend them, but doesn't know about cutting them. I have showed him though, and I think he knows all about it now. The Captain was pleased with what I did and said I was becoming quite a netmaker. He told Prine the same thing, which nearly knocked Prine over, as Prine said he had never heard of his making such remarks before about anyone. Do you think I am foolish to tell you, dearest? Nothing special happened today: it was just dredging all day, and bringing up all sorts of queer things. Just before dark we got into Matsushima 


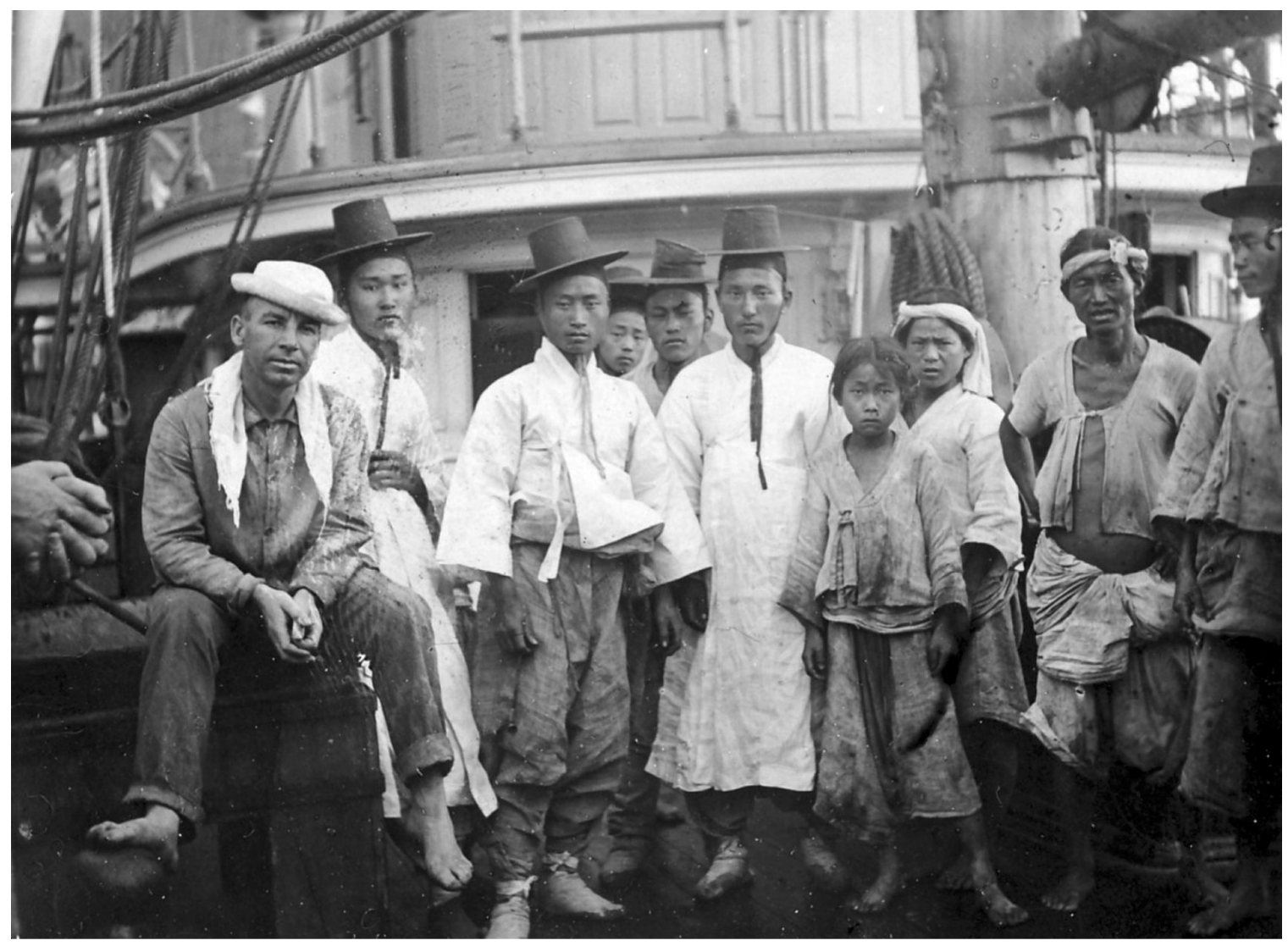

Figure 32.--Koreans from Matsushima Island on board Albatross. U.S. National Archives.

Island (Fig. 32), in the Straits of Korea, where we are going to stay till Monday. I will write you about the place tomorrow. Well, good night and "duck's rest", dear. God bless my precious wife.

July 29. Had the weirdest time today. We anchored in a little bay, about two miles away from the main town on Matsushima Island. This island is all steep hills and deep valleys, all cultivated up as high as there is good soil, and the tops of the hills wooded. The land is so steep that it has to be cultivated in terraces. Prine and I went ashore at 5A.M. and took a lunch, intending to walk around and see the island. We walked along the trail to the other village, and sat down to rest on the outskirts by a Japanese house, where they were drying squid, caught last night. We had only been there about 5 minutes when a police officer came along, and made signs for us to follow him. We didn't know what was up, or what we were being "run in" for, but we went. He took us to his house (which was also the Police Station, he being the Chief of Police) and beckoned us to enter. We accordingly removed our shoes, and walked in. We all took chairs around a table, and he treated us to
Japanese sweetmeats, and we conversed by signs as well as we could. We wanted to buy some little mementos of our visit to the island, but he told us there were no shops. However, he found a man who had some things he would sell, and I bought a couple of awfully pretty boxes. After this the table and chairs were removed, and our host adjoining into the next room, appeared in a kimono and we all squatted on the floor, in which attitude he evidently felt much better than when seated in a chair. All this time, the natives had clustered in swarms about the house to see us, as we were the first foreigners to visit the island and many, if not most of them, had never seen white men. The population of the island is 5000 Koreans and 60 Japs. The Koreans are the queerest people I have ever seen. The men never have (or only rarely have) beards, and it is almost impossible to tell them from the women. The young boys and girls are absolutely impossible to tell apart. The men wear loose baggy clothes, of material like what potato sacks are made of, only white, and queer 2 story hats shaped like this and made of fine black mosquito netting.

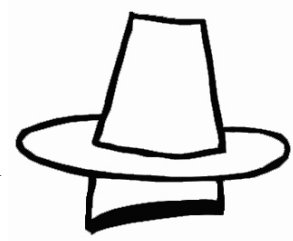


I did not see any beings who could with certainty be regarded as women. The Japs dress as Japs do in their places and live in the same kind of houses. Well, to get back to my story, about an hour after we arrived, we saw Dr. Gilbert, Dr. Heath, Dr. Torrey, and Burke and Dr. Goto pass the house. We called to them, and they came in. About 11, the surgeon and Metters came by, and also came in. At 1, our host served dinner which we ate with chopsticks seated in a circle on the floor, and of course, shoeless. I forgot to say, we had been drinking tea intermittently all morning. It was real Jap. tea and very good. It is served hot in little cups without handles, and has neither milk or [sic] sugar in it. The lunch was fine; we had boiled rice, stewed chicken, and fried squid, and Jap. pickles. At home we only use squid for bait for fish, but out here they are one of the principal articles of diet. They taste like shrimp. You know what they are, don't you? They look like this, and belong to the same class as the octopus, only they swim around in the water.

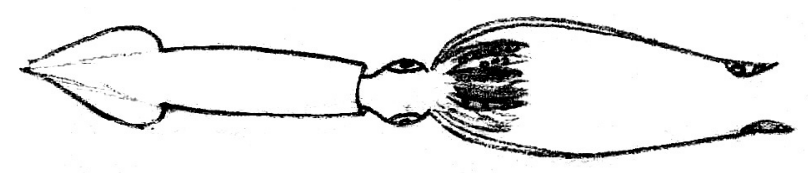

After lunch we stayed awhile, and then walked back to the ship. On leaving, our host gave us a memento. He gave me a nice little box made of cedar for collar buttons and things. It is round with a cover in the middle, and is very

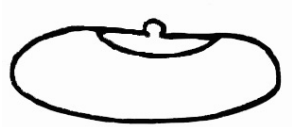
well made Do you know these big abalone shells, dear? They get lots of them to eat here, and cut the animals out and throw the shells away. The animals are dried in the sun and shipped away. I picked up a nice lot of the shells on the beach. The way they get them (which is done by the women) is to swim about from 50 to 100 yards from shore, with a big pair of goggles on, which fit closely about the eyes, so they can look down into the water. They push a box along in front of them, which acts as a float to help them swim, and as a receptacle for the shells. When they see one they dive down and bring it up and pop it into the box, and then go and hunt for more. They will bring up the shells from 15 fathoms [ $90 \mathrm{ft}$ ] of water. Rather good swimming to go so far under, isn't it, dearest? We got underway at 5 , and are now steaming out to sea, in perfectly quiet water, with Nagasaki for our next port, dearest.

July 30. We have been dredging all day. The sea had considerable motion, but could not be considered rough. The Paymaster had a "queer bilious feeling", so stayed in his room most of the day. We tried one of my new nets today, and the Captain told me it was a very good looking net, which was quite nice of him. The sailors at Hakodate, when they went ashore, all bought fish net undershirts with very short sleeves, which with pants constitutes their costume; boots, of course, are not worn in warm places, all the sailors going barefoot. These shirts have meshes big enough to pass a pencil through anywhere, and are mainly white, with lines of bright red and sky blue. They were very gaudy at first, but I noticed today that they were all a homogenous dirty white, all the fancy colors having washed out. Nothing special happened today, dearest, in fact, it was one of the dullest days we have had. I am so anxious to get to Nagasaki and get some more letters from my precious wife I don't know what to do. I do love you so, precious. Well, good night and duck's rest, darling. One more day is over, and we are so much nearer together again, sweetheart.

July 31. Dredging again all day in the Straits of Korea. Had the greatest joke on Dr. Gilbert today. He was in the lab with Dr. Heath, and thought no one else was around, and was telling him that he thought he would be here and dredge another day, because it was such a nice place. To make sure no one would understand what he was saying, he was talking in German. I have two men in the lab now making nets; Hanson, and a man named Hurliby, and a man named Gibbons, who washes bottles and does chores. Well, Hurliby happened to be in the lower lab at the time. Now he happens to have been brought up in a German school in New York, so it is just like English to him. He listened to what they were saying, and then came to me with a smile a foot wide and told me all about it. It happened also that one of the firemen was looking in at the window at the time, and he understood it, and told all the men forward, so it was all over the ship in about 5 minutes. Dr. Gilbert delights in secrecy: he will never tell what we are going to do or where we are going to go: but this evening the Captain got after him and made him promise to tell more about things. I don't think he and the skipper get on very well. The Captain just issued an order that no one was to be allowed on the bridge in the evening, which was evidently aimed at him, as he likes to go up there after dinner, which none of the rest of us do. Well, precious, I will close this now, as there seems to be a possibility we may get in to Nagasaki tomorrow, and I want to send it off first thing to my darling wife who I know is waiting to get it. Good night, dearest dearest, Mary; God bless you, dear. From your most loving husband

Austin

\section{Nagasaki, Japan \\ Aug. 4, 1906}

Dearest dearest, dearest, Sweetheart,

We have just arrived in Nagasaki, and I have just got your letters dated May 8 and May 10. I never was so glad to get any letter in my life before, dearest wife. I am awfully glad your mother sees things in the right light, aren't you, dear? It makes everything so much better. Aunt Eve 
makes me tired: I should think you would like to tell her to mind her own biz. I know I should. I don't see what she's got to do with us, anyway. I see by the card you sent darling that you are on your way to Naples and are going to sail from there to N.Y. You must have had a great trip, precious. I do wish so I could have been with you. We will take lots of trips together in the future, won't we dear? And we will visit lots of places together neither of us have seen before. I am awfully anxious to have you tell me all about what you have seen, dear, because you went to lots of places I didn't; in fact, most of the places you visited, I didn't see. I'm awfully lonely and dismal out here without you dear. I didn't realize it could possibly be so bad. I would give worlds to see your pretty face dear. I get so lonely feeling and blue sometimes. I just don't know what to do. If only I could see you, if only for a second I should feel so happy. Somehow, dearest wife, I love you more and more every single minute, and darling, you never meant half so much to me as you do now. Nobody ever had so dear and noble a little wife as you, Mary. I get prouder and prouder of you all the time. Dearest, as I have so often told you, you are, and always will be the one object in my whole life; the one thing I have to live for, precious, is to try my best to make my darling, darling wife happy, as happy as the best, and finest and dearest and noblest little woman in the world deserves to be. I am going to try my very best all my life, dearest. I have often told you, dear, when we were engaged and afterwards, what you mean to me, but somehow you mean twice as much now, dearest; every time I think of you (and I think of you all the time, sweetheart) I realize more and more what a treasure I have got for a wife, what a dear little sweetheart and what a noble friend: the best friend anyone ever had in the world. I hope you won't mind my writing you all this, dearest, but it seemed as if I just had to tell you again. Somehow, dearest the time isn't going nearly so fast as I hoped it would, and seems to lay more and more all the time. I am so homesick and lonely, dear: I do hope you don't feel as badly as I do. I think Japan is about the meanest place I ever saw. All the towns the same, all horrid wooden houses, all hot and dusty. I am so sick of it, I don't know what to do. It may be better here, but I haven't gone ashore yet. Well, dearest, I hope this letter isn't too gloomy; but I do love you so Mary that I have to tell you my feelings once in a while, precious: it seems as if every day out here I love you twice as much as I did the day before. Won't we just be the happiest couple in the world when we meet again, dearest?

From your most loving husband who would give up everything in the world for just one kiss from his own dear sweetheart.
Nagasaki, Japan

Aug. 5, 1906

Dearest dearest, dearest, Sweetheart,

What do you think I have been doing today? Mr. Hepburn and I went ashore to look at some teasets, and I bought one for you, dearest. I do hope you will like it, precious. We looked at lots and lots of them, but I think the one I got was the prettiest of them all. It has a dozen cups and saucers, a dozen plates, two large platters, 2 larger platters for cakes, tea pot, milk pitcher, and sugar bowl; 42 [43] pieces. They are the most delicate china, with little landscapes, and some birds on each one. I don't know if you like birds on china dearest, but this is the finest work I ever saw: the landscapes are very pretty, and the birds are beautifully done, and not sort of any old thing, as you generally see them. There are 12 different designs. A cup and saucer and plate comes in each design, and are different from all the other cups and saucers and plates. One design resembles a marsh, with a pair of mallard ducks flying on it. The marsh has a sheet of water, and is composed of iris in blossom. One other is an owl sitting up in a pine tree. Another is a bunch of herons flying over a bed of iris. Another is some cranes on a meadow, etc. Of course, there are clouds, etc. The colors are awfully delicate and pretty. It is a much prettier set than I ever saw at home. I do hope you will like it, darling. I paid $¥ 25$, or $\$ 12.50$ for it, which Mr. Hepburn said was very cheap. They had a lot of these heavily gilded sets, but I thought for our home, dearest, we would like one sort of plainer; the gold ones are rather showy. This one is exactly as good china, the very best made here, but does not have the gold on it: you see, it is real gold they color it with, and that is what makes them so expensive. Hep has his eye on a perfect beauty he was going to buy, but I don't like it nearly so well as I do ours. It is heavily gilded and all the pieces have just the same design. It is a magnificent set, but I thought one like it would sort of be too showy for us, and the china really isn't any better. It cost you $¥ 100$, or $\$ 50.00$. I am awfully anxious to hear what you will say when you see our set, dear. I was going to have one made up with your initials on it at first, as I wrote you, dear, but when I examined some, I concluded that any addition to the design would sort of spoil them: it would take away from the dainty Japanese look, and give them a sort of mongrel European appearance. Don't you think it would? I got something else for my darling little wife today: a silver belt buckle. It is very heavy, and one solid mass of carving, representing a couple of dragons. It is fantastic and odd, but is very pretty and unique. I paid $\$ 2.50$ for it: the silver in it is worth nearly $\$ 2.00$. I hope you won't think me too extravagant, darling little wifey, but you see there are some things here which I think it really pays to get; they are so much cheaper than at home. The tea set would have cost 3 or 4 times as much back at home, and the belt the same way. Won't it be fun, darling when we meet again to compare notes and look at things. I am 
just dying to hear what you will have to say about what I have got for you, sweetheart, I love my dear, dear, dear little wife so much I that I am tempted to buy everything nice that I see. When we get to Washington won't we have fun fitting up our apartment, dearest? Won't it be just great to go about and buy things together? But the best of all, darling, to me, will be the nice long evenings we will spend just us two together, precious, you and I, reading to each other.

Do you think I am silly, darling? Won't we be just the happiest couple that ever was? Well, dearest, it is getting late and the lights will soon go out, so I will close. Goodnight dearest darling wife, and "duck's rest". Give my love to your mother and Betty.

With heaps \& heaps \& heaps more love \& kisses, From your most loving husband.

\section{Nagasaki, Japan \\ August 6, 1906}

Dearest, dearest Sweetheart,

I have just written you about the tea set I bought for you dearest. It came on board today all packed up in a big box, with lots of straw and cotton, so it will get home safely. Mr. Hepburn and the doctor and I went ashore and visited the same shop today, and I got you the prettiest tea caddy I ever saw, darling. It is about 7 inches high, with a design of iris, beautifully done, all around it, and a sprig of iris on the cover to lift it off by. It stands on a little ebony stand. I forgot to say it is silver, with the iris standing out in high relief. One of the beauties of the tea set and tea caddy, darling, is that if you do not like them, we can sell them for lots more than we paid for them, just as we can the furs I bought, dear. Did I tell you about the tea set we saw? We looked at some of the most exquisite sets you can possibly imagine: the very thinnest china, covered with beautiful figures in gold, for all prices up to 100 yen $(\$ 50.00)$. He had one of "Satsuma" ware which beats anything I ever saw in workmanship. The cups had flowers all over the outside, and gold stars and a central design inside. It was a small set, with only 6 cups and saucers, and he wanted 185 yen for it (\$93.00). It looked even better through a microscope than without one. He told us it took a workman a year and a half to make it. I never saw so many curiosities as he had: bronze elephants, lamps of all kinds, temple bells, pagodas, all kinds of silverware, carved ivory, everything. He had a carved wooden turtle which was even better than the ivory statues we saw at Washington. He told us he had a live turtle, and asked us to come and see it, which we did: he had it in a little pond in the courtyard of his house. This is the first Japanese courtyard I have seen, and it was a pretty as it could be. There was a little pond in front, with little rocky islands in it, and with a couple of bronze cranes standing in the water, and a bronze crab or two, and a bronze frog on the rocks, all very life-like: behind the pond, a little path led through a maze of pretty plants of all kinds, to somewhere in the rear. The path was only about 6 inches wide, and everything else was correspondingly small; so the general effect was that of a larger pond, with quite a large grove beyond, although I dare say the whole area wasn't more than $20 \mathrm{ft}$. square. I never saw so much apparent size compressed into so small a space before. When he brought off our tea sets, he brought Mr. Hepburn and me each a present: a pretty little jar of Nagasaki ware on a little ebony stand. They are white, shading to blue at the top, with a raised iris design on them, and are very pretty. Nagasaki is a very busy place: it is about the size of Hakodate, but there are 4000 or more foreigners (mostly Russians) here. There is a big ship building plant here, and vessels stop here for coal. All the ships from Canada and Frisco call in here, the "China" (from S.F. to Manila) and the "Empress of India" (from Hong Kong to Vancouver) being anchored out in the harbor now. A Russian steamer left yesterday for Odessa, and another from Odessa, is here, bound for Vladivostok. There is a Danish and a Norwegian steamer here, and several English. One of the English steamers, the "City of Birmingham" of Hong Kong is a small wrecking tug. A very large steamer, the "Dunbarton" was wrecked a while ago on Saka$\lim [\mathrm{sic}]$, and the wreck was bought for $\$ 500$, and this little steamer was fitted up to raise her. She got her off all right, and both of them came back using their own steam. The wrecked boat was practically undamaged. The "Chang Rioug", a steamer flying the Korean flag, came in this morning. It seems strange to think of the funny Koreans owning and running modern steamers, doesn't it? When we came into Nagasaki a great swarm of "sampans" filled with peddlers came around and could hardly wait till the anchor was down to come aboard. When they were allowed on board, you never saw such a rabble. Some were barbers, some shoe makers, a number Chinese tailors (the Chinese have a monopoly of the tailoring business here), but most of them were peddlers, with things to sell. They spread their wares out all about the deck: vases of all kinds, cheap jewelry, coffee \& chocolate sets, silks, embroideries, and picture postals. You can't imagine what a mess it was: the deck resembled a bazaar. The paymaster bought a "silver" cup with a dragon on it for a couple of dollars; but when he tried to shine it up, a great chunk of plate fell off, disclosing a dark brown looking metal underneath. It doesn't pay to buy from peddlers any more here than at home. There is a big hotel here which does a thriving business in the tourist season, but is comparatively empty now. On the hotel register, as in all Jap hotels, there is a column just before that for the names where you have to put down your nationality. Walking about the streets here, you can't help wondering at the numbers of foreigners: almost all are Russian, but a few are English. This used to be a great Russian center, and has again become so since the war. They have an institution here known as the "bazaar", which 
is much like our department store. They have for sale all kinds of cheap stuff, cloth, general dry goods, cheap lacquer ware, fans, children's toys, etc. There are no regular departments, but you keep seeing the same things as you go down the line. The building is very ingeniously contrived, so that if you once get in you have to go all through it before getting out again. I have drawn a sort of diagram of it here.

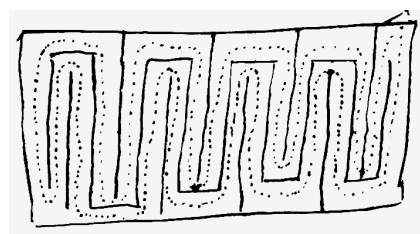

The lines are walls (with counters running their entire length without a break), and the dotted line is how you have to walk when you once get inside. You can see by following the dotted line that, no matter which side of the first partition you start, you have got to go through the entire building before you can get out. In this building the one thing one hears from the moment of entering until he passes again out of the door, is 'Gemmen, please buy somewing" repeated over and over and over again.

We are going to leave early tomorrow morning so I'm afraid I shan't get a chance to post this letter here, but we are going to be in another port in a day or two I believe. Well dearest dearest precious little sweetheart, good night, and duck's rest, darling God bless my dear dear wife.

August 7. We have been at sea all day, dredging and getting all sorts of queer things. It was hot during our stay at Nagasaki, and it is still hot: you have to expect warm weather this time of the year here. Nothing special happened today. When the dredge was down, I worked making nets with Hanson. Two men ran away at Nagasaki. One of them, Riley, used to be chief master-at-arms, and got $\$ 175$ a month. He was a strapping big fellow, and made a good policeman, as he could handle drunks easily. Unfortunately, he was rather fond of booze himself, and was constantly in trouble. This culminated at Unalaska, where he went ashore without leave, and came back full. He was court-martialed for it, got 5 days in the "brig" (jail) and was reduced to fireman at $\$ 30$ per month. He had about \$200 due him when we got to Nagasaki, which he drew, and we saw him no more. It is universally considered a good riddance. The other man, a seaman named Devine, was a worthless chap, and always got drunk whenever possible. He got full at Hakodate and was brought aboard by 4 policemen. We are rather the gainers by his flight, also. We had great luck with the men at Nagasaki; everyone got back "C\&S" (clean and sober). Well, precious, another day has gone by and we are so much nearer together again dear. Good night sweet wife, "duck's rest", and God bless dearest.
August 8. Same old thing, dredging and making nets all day. It is still hot and sunny, but we have an awning spread over the poop, so it is very comfortable up there. Hanson brings all the nets up there to make, as it is very uncomfortable in the lower laboratory. I learned some bad news today, dearest precious wife: we may not be back so early as we thought. Dr. Gilbert is one of those people who delights in secrecy, and no one has known a day ahead where we were going or what we were going to do, or, most important, when we were going to get back. Last night the Captain said he had had enough of this sort of business, and he was going to demand something more definite, so he made Dr. G. furnish an itinerary of what he proposed to do. As a result we found out what he really expects (in spite of what he told us about Oct. 31 as the final limit) to get back about the middle of December. I don't know when I ever felt worse about anything sweetheart: it does seem so awfully hard; so much time had gone by that I was beginning to count the days before I could hold my little darling in my arms and kiss her sweet pretty little face. It is awfully hard, dearest, but I don't see any way out of it. However we may get so much done before then that we will have to come back: we will hope for the best anyway, won't we dearest. I am awfully glad you are back in N'ville, dearest, and not out in Cal., as it will be lots easier for you to be among friends, won't it, dear? Well, dearest precious little wife take the very best of care of yourself, won't you dear? I am taking care of myself, dearest. Good night, sweetest darling duck's rest and pleasant dreams, dear wife.

August 9. Still at it, dredging all day. It was warm today, but not very really hot. We had the funniest time today. We got lots and lots of jellyfishes in the net, and two of the sailors, the bos'n and I had to get them out. They are light brownish yellow ones, with black radiating lines on them, and long streamers hanging down underneath. The whole net was just covered with the streamers sticking to it. Well, these streamers are provided with stinging cells, and feel like nettles when they touch you. In clearing out the net we all got stung more or less about the hands and arms. We didn't think much about it, but about 8 , I felt a sort of sunburny feeling as if I was covered with nettles pretty much all over. That was about 9 . About quarter to 10, I decided to chase up the doctor, to see what he could do. He told me some stuff to put on it, and I went to Baldwin, the hospital steward, to get it. He sleeps in the upper lab, and everything was dark in there so I went in and turned up the light, so as to get him to mix up some stuff. What was my surprise when the light was turned on to see the 2 sailors and the boss in there. They had come to the hospital steward to see what could be done: they were rubbing themselves and cursing softly. Well, it all got fixed up, and the doctor gave us some powder to take if the stinging began again. The bos'n took his dose of powder and said "I ain't going to risk any more of this; I'll take mine now", 
and swallowed the whole thing. I feel all right now, dearest, all the sting is gone, so you needn't be worried any about it. Good night dear dear dear precious little sweetheartwife, duck's rest and God bless you darling.

August 10. I have to get up and go forward about 1 last night, and what should I see but the 3 sailors who got mixed up with the jellyfish all sitting on a tool chest, smoking their pipes in a melancholy row: they hadn't been able to sleep a wink. I jollied them awhile, and then went back to bed and slept like a log. This morning I can't feel it a bit, and feel just as good as ever, but the 3 sailors are a miserable looking trio. You see, they had to do the work of picking out the jellyfish, while I only superintended, and lent a hand now and then, so they got lots the worse of it. One of them had gotten to sleep about 3 a.m., but the other 2 had sat up on the chest all night and waited for morning. One of these men (who had his hair clipped very short) had managed to get it all over his head, and had a lovely time. He had gone to the hospital steward yesterday P.M., and he had given him some picric acid for it. Now picric acid is a very powerful stain of a brilliant yellow color, and he had rubbed it well on all over him. His appearance this morning was most remarkable; he was entirely a brilliant lemon yellow color, except his hair, which was green, one of the funniest sights I ever saw. He couldn't see the joke though. The doctor says the yellow will wear out in a couple of months. We have been dredging all day, dearest, but fortunately have caught no jellyfish. Nothing particular has happened. It is still warm and sunny, but it rained hard early this morning. Well, precious wife, goodnight and God bless you, my dear one.

August 11. Dredging all day again, warm and sunny. We are down in the Linschoten islands, south of Japan, but are soon going up to Kagoshima, and then to Kobe and Yokohama. Almost everybody has taken to sleeping on deck now. All the officers bring up their mattresses every night and spread them out on the poop, as it is nice and cool there, but very hot in the ward room. Once in a while there comes up a shower and they all have to scuttle below. The men too have found places to sleep on deck. All the men sleep in hammocks, which they are able to tie up almost anywhere. One of the net frames is made like this, a couple of big sort of half circles, connected by 2 bars, the whole thing standing about $5 \mathrm{ft}$. high. One of the sailors uses this as a brace for this hammock, and then spreads a little awning of canvas over the top, so if it rains he won't get wet.

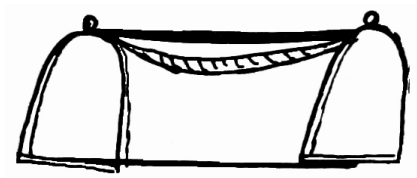

We have found out pretty definitely that we are going to start home about the first of November from Yokohama.
It is terribly hard for me, precious, but I suppose we must put up with it. However there is one possibility. We are going up to Sakalin from Yokohama, starting about Sept.1. Now Sakalin is pretty far north and winter sets in about the middle of Sept., and the whole place begins to freeze up. The capt. says if we strike any ice up there he will come right back, as the boat is not made for an ice-breaker. Let us hope for the best, dearest. The captain says this whole trip was planned most absurdly: we were up in the Aleutians in the spring when the ice was barely out, here we are in the southern part of Japan in the midsummer, where it is very hot, and we are going to Sakalin in the fall, just in time to get it cold again, as a preparation for frizzling in Honolulu. Besides that, we were near Sakalin once, when we were in the Okhotsk Sea, and instead of running over, came down here, intending to come back again, thereby losing a couple of weeks. Well, dearest dearest wife, good night and God bless you dear. "Duck's rest", precious.

August 12. Dredging all day again. One of the sailors today told me that the name he shipped under wasn't his real one, and said about $3 / 4$ of the sailors in the navy were enlisted under made up names. He said in the Spanish war he was on the Baltimore, and just before they got to Cuba 282 out of the crew of 350 men changed their names and got their real ones, so if anything happened their friends would be notified. Sort of a funny state of affairs, isn't it? Most sailors are a worthless lot, anyhow, and wouldn't be sailors if they could be anything else. Predisposition to booze is what keeps most of them where they are. A number of our men have been petty officers over and over again, but have been reduced for going on awful drunks or filling up on shellac or bootblacking or perfumery when on board. It has been warm today, but not uncomfortable, and, as it was cloudy with a nice breeze, it has been very nice on deck. Dr. Goto (a Jap professor who has been on board since we were at Tsuruga) and Mr. Higurashi, who belongs to the Jap. Fish Commission, are going to leave us at Kagoshima, and Dr. Torrey will leave at Yokohama. Dr. Goto is a Harvard man and studied the same things I did, under the same professor, Dr. Mark. Mr. Higurashi is not as companionable as he might be owing to his inability to speak English. I am impatient to get to Kagoshima because it will be another place behind us, dearest, and we shall have one less place to visit before starting home. Dearest precious wife, if you could only realize how lonely and homesick I feel way out here, darling: somehow it sort of gets worse and worse all the time. I keep realizing more and more and more every single day darling how much I love you Mary, and I realize more and more and more how you are truly all the world to me. Won't it be a happy when we meet again, dearest? We will have to plan a little honeymoon, won't we? A camping trip or something. Won't it be great fun? Well, dearest, dearest, dearest wife, good night and "duck's rest". God bless you dear Mary. 


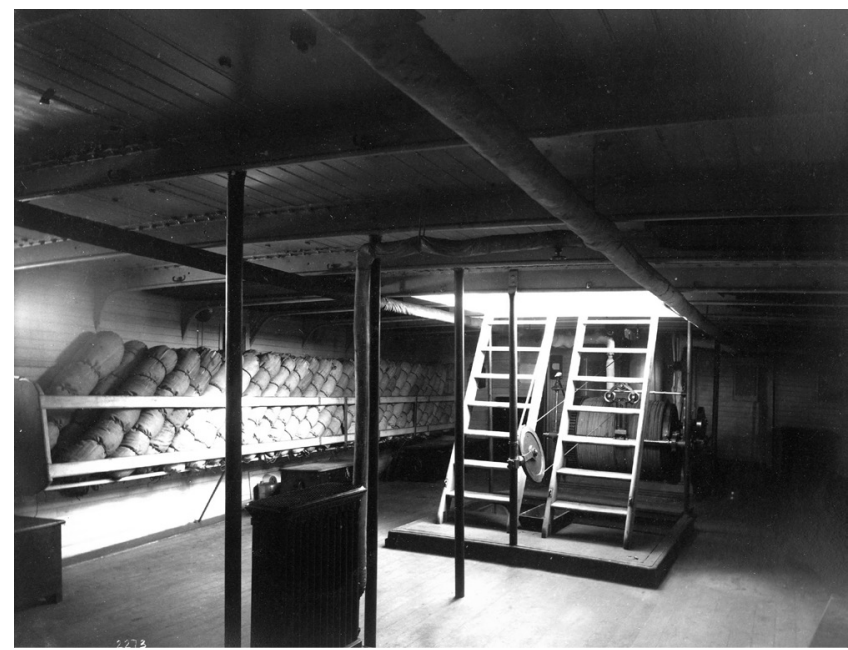

Figure 33.-A, berthing deck on Albatross. Note pulley near companionways, which broke free on 14 August. U.S. National Archives.

August 13. Still dredging about the Linschoten island. It has been quite warm today, but not uncomfortably. The sea has been as smooth as glass. We are in the middle of a pretty group of islands, each with a high mountain or two on it, some of the mountains smoking. We have lots of pumice stone floating today, thrown out from some volcano near here. All this region is volcanic. Very likely next winter the ship will be at San Diego instead of S.F. The paymaster told me today that if we were down there, he could arrange for me at one of the big hotels to get navy rates, so that we could stop there. The navy rates are about half of the ordinary rates to people. You see I shall probably have to stay with the ship for a month or so before going east to fix up accounts and things. A month in San Diego would be great, wouldn't it dearest? It is a big winter resort, and is said to be a fine place. It is funny, but the captain has been especially nice to me since leaving Hakodate, nicer than to any of the others. He and Dr. Gilbert don't seem to hit it off very well. Today the net came up full of mud, and spilled all over the deck, and Dr. G. told one of the sailors to bring the hose and wash it up. The capt. heard him and said, "Doctor, if you want anything done, tell one of the officers, and you will get it done promptly." Of course, everything on the ship is supposed to be done through the ships naval officers. The captain sailed in to him the other day about using too much alcohol, too, to Dr. Gilbert's great disgust. The officers are all congratulating me as standing so high in the captains' favor, and wish they did. Well, dearest darling wife, another day has passed, thank God, and we are so much nearer together. Good night and God bless my little Mary.

August 14. Had quite a lot of excitement today. We began dredging as usual at 8 o'clock: well, the net had only been towing about 10 minutes when it struck a reef on the bottom, and as the ship was going ahead at half speed, all the strain came on the dredging rope. There is a big spring on the dredging cable which tells how much strain there is on it, and it went up to 6 tons right away. The strain was so great that it pulled out a big pulley (Fig. 33) just ahead of the dredging engine, which flew back and just missed the man who was running the engine. This put a kink in the wire rope used for dredging, and it broke at the kink and 2400 feet of it went overboard. Well, the damage was repaired in about 3 hours, and we lowered the tangles. These tangles are big swabs of hemp about $6 \mathrm{ft}$. long fixed to a bar. They are used where the bottom is too rocky to risk a net, and sweep up over the sea floor, entangling anything that happens to be there and bringing it to the surface. They are arranged on an iron bar like this.

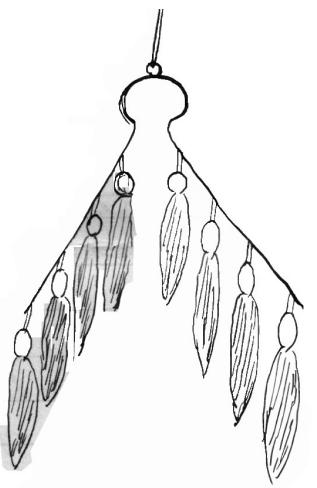

They are made from old rope frayed out. These dragged all right for a while, then suddenly caught between a couple of rocks or something. The big spring showed a force of about 6 tons again, and the ship took a list to the side where the tangles were. The ship was backed, and we sailed all about for about half an hour before we succeeded in getting them freed. The dredging is all done from a long boom a pole which projects up at an angle from the fore mast out over the water, so as to protect the propeller from getting tangled up in the dredging line, as it keeps the dredging line out to one side of the ship.

When not in use, this boom is brought inboard, and secured amid ship, so it looks like any other boom. Well, when the tangles caught this boom bent like a bow, and when everyone was hold-

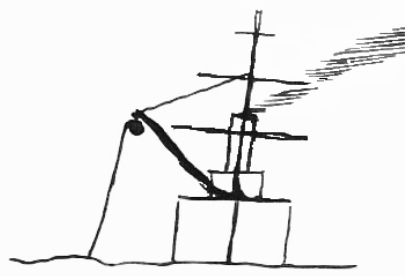
ing their breath to see what would happen, one of the sailors was heard to say, “ Boys, if she breaks don't all cheer at once. They may hear us." The men hate dredging worse than poison, as it is hard work for them, and would have been tickled to death if the boom had given way, or something happened to disable the dredging gear. After the affair with the tangles, all went smoothly, without any further incident. Well, precious goodnight and "duck's rest" dear dear dear wife. God bless you, Mary.

August 15. Dredging all day again: warm and sunny, with a smooth sea. We are going to Kagoshima tomorrow, and from there to Kobe. The capt. says we will be in Yokohama the first of Sept. Nothing special happened today, darling, 
everything went smoothly, and we had no accidents at all. I happened to glance through a medical journal of the doctor's today, and found an article on women's bathing. It said just the same thing as I told you once, dearest, do you remember? It said that when you are indisposed to bathe sparingly, and only with tepid water, and at all other times to bath (something) with only tepid water. You will take the greatest care of yourself precious, won't you? I am taking the best care of myself, dearest. We all weighed ourselves this evening. Metters got a big pair of scales and tied them to the boom up on the poop, and then arranged a piece of rope so we could sit in it and be weighed. I weighed 140, which is 10 pounds more than when I was weighed last, in spite of the fact I am now wearing the thinnest possible clothes. So Metters has gained 40 pounds since he has been on this boat. The general opinion seems to be that it is my beard which accounts for the extra $10 \mathrm{lbs}$. Well dearest it is getting late, so good night dear sweetheart: "duck's rest" and God bless you, Mary.

August 16. We have been dredging all day again, as usual, and are now anchored near the entrance to Kagoshima Gulf for the night. It has been warm and calm all day. Nothing special has happened. We expect to get into Kagoshima tomorrow. The shore along the gulf is very pretty, mostly steep and hilly, and almost all cultivated. It is so steep in most places that it has to be cultivated in terraces to keep this earth from washing away. The whole country is beautifully green, the tops of the hills surrounded by fluffy white clouds. I suppose you are now on the sea yourself, darling, coming home. Good God, I wish I was going home too. I try to think that the longer I am out here the sweeter it will seem to see you again, but dearest it isn't consoling a bit. I couldn't even want to see my precious wife more than I do now. I seem to love her more and more and more every day, and she means more and more to me every single day. When we get together again we will never be separated again, will we darling? Well, precious, goodnight and "duck's rest" dear. God bless my little wife.

August 17. In Kagoshima at last; another stage of the trip over, dearest. Any stop we make seems to bring us nearer together dearest. We dredged all the morning, and took one haul this P.M. The net came up so full of mud that we had to drag it 2 or 3 miles to wash some of the mud out before we could lift it in. They rigged a tackle on it and hoisted it with the donkey engine, but the rope broke before they got it very far up. They tried another, and that broke, too. The 3rd attempt was successful, and they got it in over the deck. The nets are tied up with a rope around the end, so when you want to get the stuff out, you just untie the rope. When the rope was untied this time, several tons of mud fell out and splattered all over everything and everybody. We turned the hose on it and washed it down, but only got 4 sea cucumbers and about a peck of clam shells out of the whole business. I will close this letter now, dearest, so as to get it off as soon as I can. Well, dearest, dearest, dearest wife, I shall write you every day we are here. Keep up your spirits dear little girl, until we meet again. If you only knew what you mean to me Mary, my dear dear wife.

With heaps and heaps and heaps of love and kisses From your most loving husband

\section{Kagoshima, Japan \\ August 18, 1906}

\section{Dearest dearest Sweetheart,}

Sent a couple of letters ashore to be mailed to you this morning. We have been lying here all day. Most everybody went ashore, but I stayed aboard, as it was hot and sunny. I learned afterwards it was simply baking ashore. Some of the people on the ship got letters here this morning, which had been forwarded from Nagasaki. I have got all your letters up to the time of your sailing, dear, and I am looking forward anxiously to getting a bunch of them at Kobe. You can't realize what your letters mean to me, dear little one, way out here. We are going to leave here Monday morning, and begin another stage of our journey. There are only 4 stages more: from here to Kobe, from Kobe to Yokohama, from Yokohama to Sakalin [Sakhalin], from Sakalin to Yokohama again, and then we are homeward bound. Dr. G. refuses to tell anything about what he intends to do except what the captain screws out of him. All the captain knows is that we shall get to Yokohama about Sept. 1, and leave at once for Sakalin, and start for home Nov. 1 at the latest. The other dates the captain says, he doesn't care so much about. Dr. G. has set all the men on edge against him; they every one of them cordially hate him, as do all the officers. He has frequent rows with the captain. Somehow, he and I seem to get along together finely, and haven't had any unpleasantness at all, nor do we seem likely to have. They had a shake up today in the crew: every man in the lab was raised from "seaman" to "carpenter's mate", thereby getting a stripe on his arm and $\$ 6$ more a month. The carpenter was raised from "carpenter's mate" to "blacksmith", with a raise of $\$ 15$ more a month, and the "blacksmith" was made "boiler-maker", with the same raise. It is funny, but none of them are Americans: my man is a Swede, the carpenter a Finn, and the blacksmith an Englishman. Well, precious, another day has gone, and we are so much nearer together again, darling. How I do long to see my sweet little love again. Good night, dearest, and God bless you. "Duck's rest", darling.

August 19. Went ashore this P.M. with Tongue and had quite an interesting time. Kagoshima is the capital of Satsuma province, famous for its great men and its "Satsuma" ware. Admiral Togo, Marshal Oyama, and all the famous generals of the Russo-Jap. war are from Kagoshima. Tongue and I took "'rickshaws", and went 
out to a factory where they make Satsuma ware, and saw how it is made. Satsuma ware looks like ordinary first class china, but is all covered with crackles; sort of honeycombed with them. The greatest value, however, comes in the decorating: it is usually most exquisitely decorated. It is made like ordinary china, the crackling being done in the baking: we watched the men painting designs on it a while and then the Paymaster and Lee, the captain's cook, came along and told us we were not in the chief factory. We went along with them to the biggest factory in the country. It was a great place. In a big room down stairs they were modeling the things out of clay, and in a big room just over it they were painting the designs on it. In two little rooms adjoining they had samples for sale. I forgot to say that when we got there we found Dr. G., Dr. Torrey, and the surgeon already there. We rubbered around a while, and I bought 6 of the cutest little egg cups for you, darling. They are shaped like this, and are plain white crackled, with a little sprig of cherry blossoms, and 2 or 3 scattered flowers on each one. The design is very prettily done. They are not made with a mould, so I had a hard job picking out half a dozen the same height, but I finally got a set that matched almost perfectly. They cost 15 cents each, which seems rather high, but Satsuma ware is the very best in Japan, and brings the highest price. Mr. Hepburn got a set just like mine yesterday. After leaving the Satsuma factory, Tongue and I returned to the boat. Kagoshima is a funny place, something like Hakodate, but on a bigger scale. It is not an "open port" so no foreign boats call here, consequently few foreigners ever visit it. There is only one foreign resident, an old English school teacher. Well, good night, dearest darling precious wife. "Duck's rest" and God bless you darling.

August 20. Got under way early this morning, and did our usual dredging stunts all day. It was rather hot, but there was a good breeze. Nothing special happened all day. I do like a real busy day, dearest, because it goes so much quicker, and as its close brings us one day nearer together, precious. Oh! How I do long to see you again little Mary! The time does seem to crawl so slowly and I sort of get more and more homesick every day. Won't we be happy when we see each other again dear dear dear wife? Good night dearest dearest dearest Mary. God bless you darling.

August 21. Dredging again all day: hot and sunny, but with a good breeze again. The funniest thing happened today. One of the men in the lab caught a cockroach and put it in a small bottle of alcohol with a lable [sic] and put it in the collections. Dr. G. was mousing around the collections this P.M., and spotted it. Maybe he wasn't mad! The only person in the lab. happened to be Baldwin, the hospital steward, and he sailed into him for doing it. Dr. G. got over his mad later on and made up to Baldwin: he never discovered who did it. It is quite a relief to get into port and have something else than sea fare to eat. Our sea food consists of canned tongue, canned "willie" (corned beef), canned vegetables, smoked fish, salt fish, canned salmon, and potatoes. It gets rather monotonous after a while. When I get back I hope never to see a can again. After leaving port we usually have steak or chicken for a day or two, which relieves the monotony considerably. In port, of course, we have whatever there is in the markets. At Kagoshima we laid in a supply of fine watermelons, which came in very nicely. Well dearest dearest dearest wife, good night; another day has gone, thank God.

Aug. 22. Same old dredging stunts all day, with the same lack of anything exciting. The ice machine achieved one of its break downs today, so we had to get along with luke warm water: it usually manages to give out on the hottest days. It has been hot today, but as we can wear any old rig at sea, we didn't mind it. About 5 they stopped the ship and most everybody went swimming. One of the sailors dove from the yards in the fore mast. We haven't caught anything very much the last two days, so I believe we are going to start for Kobe, as the captain is anxious to get to Yokohama by the first of Sept. After we get there, dearest, we have only to go up to Sakalin [Sakhalin] and then home! Dearest, if you only knew how I long to start home again. I sort of get worse and worse all the time, too. It seems just ages since we were together, darling. Won't we have lots to tell each other when we meet, dearest? I am so anxious to hear what you will think of the things I have been getting for you, precious. Don't be afraid to say if you don't like them, because if you don't we can sell them and get more than we paid for them dearest. Good night dearest darling sweetheart. "Duck's rest" and God bless you, dear.

Aug. 23. Dredging again all day, with very little results: hot and sunny. The skipper got after Dr. G. twice lately. Dr. G. has been in the habit of going up on the bridge evenings when it is nice and breezy, but the other day the capt. passed an order that no one would be allowed on the bridge but the watch officers, so he can't go up there any more. Dr. G. also used to bring up his mattress and sleep up on the poop, as the other officers do, but the capt. told him he must sleep in the cabin as only the wardroom officers can sleep on the poop, as it is stuffy below, as of course the ports can't be opened at sea, but it is nice and breezy in the cabin. Dr. G. seemed to think when he came here he was going to run the whole show to suit himself, but the capt. has taken him down peg by peg. The capt. has been especially sweet to me lately. Everything is going on finely. The people on the ship get on better together this cruise than they have on any previous one: usually there are lots of rows, but there have been none so far. The Dr. and the paymaster have pretty well made up now. We are going 
straight to Kobe tomorrow, and I expect to get some letters from the dearest little sweetheart in the whole world. Won't I be glad to get them though? Good night, darling, "Duck's rest" and God bless my dear dear wife.

Aug. 24. Had a most beautiful day today, cool and breezy. We spent the whole day sailing up the inland sea to Kobe. You generally hear of the inland sea as the prettiest place in Japan. I think (as do most of those on board) it has been immoderately overrated. It is kind of a broad river, in some places, quite narrow, in other miles broad, winding among hills and islands with the mountains in the distance. The hills are mostly bare and cultivated in terraces: some are covered with pine trees, mostly rather scrubby. Every place which can be cultivated has some crops or other on it and in every level place there is a village. The sea is simply covered with boats, junks and sampans, with occasional steamers passing up and down. All the smaller boats are fishermen. They catch all the fish they can, even the littlest for food. They even eat squid and shells and a peculiar jellyfish, which comes here. As we neared Kobe the boats became even thicker: simply thousands of them, almost all typical junks. We anchored about 9 P.M. at a little town near Kobe, and are going to run up there tomorrow morning. I must close now dearest, so as to get this letter in the mail the first thing tomorrow morning. Good night dearest precious little sweetheart. "Duck's rest" dear dear dear wife and God bless you.

With lots \& lots \& lots of love and kisses

From you most loving

Austin

Kobe, Japan

August 25, 1906

Dearest dearest Sweetheart,

We came up to Kobe at 10 this a.m., and anchored near the city. Dr. G., Dr. Torrey, and the surgeon went ashore and took the train up to Kyoto, where they are going to stay till tomorrow night. Tongue and I went ashore this p.m. and took a 'rickshaw ride all over the town and then went to the hotel for dinner. We haven't had a meal off of the boat since leaving S.F. (except lunches we took out with us), so you bet we appreciated it. When we went into the dining room of the hotel, there was the captain, dining with some friends he had met on shore. Kobe isn't much different from the other Jap. places we have been in, only it is bigger. It is at the base of some hills, reminding me of Hakodate. There are lots of foreigners here, as it is one of the chief shipping ports of the country. We did not find it especially interesting. We looked in at a few stores, and saw lots of fine silks and embroidery, but nothing I thought you would really like, dearest. I expect they will have all sorts of fine things at Yokohama, though. They have silk gauze table sets, centerpieces, and 12 doilies, all with pret- ty hand-painted designs, for 60 cents. They also have pretty embroidered silk shawls for $\$ 1.00$ and up. I am going to get you one at Yokohama, dearest. I have sent along with this a dozen postal cards which give an idea of the country. I have numbered them all on the back, so you can tell what they are dear. I put the numbers in the place reserved for the stamp. No.1 shows 4 'rickshaws, with Jap. women in them. These 'rickshaws take the place of cabs in Japan, and in almost all the cities, of electric cars too. The men drawing them go at a fast trot, and get over the ground quite rapidly. They charge 25 cents for a whole morning or P.M., or about 5 cents from one part of the city to another. A cab driver wouldn't make much at that rate, would he?

No. 2 shows some "sampans" drawn up on a beach. It isn't a very good picture of them: I will try to get a better one, dear. These sampans, just like these, are the universal means of getting to and fro from steamers, and moving over the water generally. In some places, like Nagasaki, they have a little house built on them, where you can go in and squat down (the roof is about $4 \mathrm{ft}$. high) if it rains.

Nos. $3 \& 4$ are street scenes. I don't know just where they are supposed to be, but they might be in any city in Japan, as they are all the same. In No. 4 you can see several 'rickshaws standing in front of stores.

No. 5 shows some better class houses reached by a neat little bridge. How would you like to live at the top of that flight of steps?

No. $6 \& 7$ show fields of iris in bloom. It is one of the commonest and prettiest flowers in Japan.

Nos. $8 \& 9$ are pictures of Mt. Fujiyama, the sacred mountain of Japan, a huge volcanic peak between here and Tokyo.

No. 10 is an image of Buddha carved out of solid rock. The priest standing on his knee shows the size of it.

No. 11 is an entrance to a temple, and the last is just a scene in Japan.

They have lots of pretty postals like these here, and I suppose lots more in Yokohama. I selected the 12 I thought would be most interesting, darling. Most of the others are people in native costumes, or waterfalls or something or other, the greater part of them spoiled by being badly colored: some of these even seem sort of cheap and loud, although I tried to select the best. Well, dearest little darling wife, good night. "Duck's rest" and God bless my dearest dearest dearest sweetheart

From your loving husband

Austin

Kobe, Japan

August 26, 1906

Dearest dearest Sweetheart,

Today I stayed on board all day, as it was hot and this isn't an over-interesting place. Most of the others were still up at Kyoto, and the surgeon had gone up to Osa- 
ka for the day. I looked at a lot of silks and things for you yesterday, dearest, and saw some awfully pretty embroidered shawls mighty cheap, but I think I can get a better bargain at Yokohama. We had a little excitement today: at about 2 o'clock we discovered the launch which had made its regular trip to shore at 1 , being rowed back by the coxswain (the man in front) and the man in the stern. When she came alongside, Crater and I went up to see what the matter was and saw that the fireman who runs the engine of the launch was drunk. He had let all the water get out of the boiler, and the whole boiler was red hot, and the woodwork around it on fire. Crater sent a machinist down to investigate it. The fireman said the pumps weren't working, and he couldn't get any water in the boiler, but the machinist found everything all o.k. The fireman had a silly don't care sort of drunk: he just laughed and said he was glad the old thing was fixed at last, so he wouldn't have to run it any more. The skipper was ripping when he heard of it. Riley was (he was the fireman) immediately put in the "brig" for 5 days on bread and water.

Later. I have just received the dearest bunch of letters from you sweetheart: the ones from Venice, Lugano, Paris, and Milan. I was so glad to hear from you, dearest, dearest wife I am glad everything is going so nicely. I am mighty glad you decided to stay in Capri, darling instead of going to Athens. Athens is very hot and disagreeable in the summer, I understand, and I think you ought to have the rest, dear. It is better you are coming home in a later steamer, darling, because I won't be home so soon as we thought. The Captain got a letter from the commissioner yesterday saying that, in view of the lateness of departure, it might be necessary to keep the boat out here longer than was anticipated, possibly until the 1st. Evidently Dr. G. wrote on to Washington and got them to send the letter. We regard Nov. 1 as the utmost limit of our stay here, as we knew the capt. is as anxious we are to get back. We may not stay long up at Sakalin, as the winter closes in early there, and the captain won't risk this boat in the ice. I don't think the captain and Dr. G. hit it off very well together. Well, dearest dearest dearest little wife, another stage of our trip is over. We have to go to Yokohama, then to Sakalin and back, and then we are homeward bound, thank God. How I do long to see my precious little sweetheart again. Good night dearest, and "duck's rest". God bless my darling darling wife.

Aug. 27. We left Kobe this morning and ran straight out to sea. We started in dredging as soon as we were well out, and have been amusing ourselves at that occupation all day: nothing extraordinary happened: we didn't break anything, and we didn't catch much. The captain was on a rampage all day, but has been very sweet to me. He was pretty well stirred up over that launch business. He gave Crater 10 days restriction to the ship for letting Riley go in the launch while drunk, and gave the same to Metters (who was officer of the deck) for not noticing he was drunk. The coxswain of the launch, a nice young chap named Alvine, was disrated and made an ordinary seaman, (A coxswain is a petty officer, and wears a stripe on his arm.), and a man named Spratley was made coxswain in his place. This man Spratley used to be a chief master-at-arms, with $\$ 70$ a month, but once allowed some of his prisoners to get full and was disrated to seaman, at $\$ 24$ per month for it. The captain has sort of taken a fancy to him, but the others don't like him much. Crater and Metters are both furious at having to stay on board while we are in Yokohama. Well, dearest another day has passed and we are so much nearer together again. Good night darling little sweetheart. God bless you dear.

Aug. 28. Dredging and sounding again all day. The sea was smooth, and it was cooler than it has been. Nothing exciting happened. I forgot to tell you, the boy Ona, the foolish sort of an individual who took care of our room when you were on board, darling, ran away at Kobe. Everybody considers it a mighty good riddance. We expect to be in Yokohama by Sunday, the captain says. We have had the most remarkable weather, this cruise dear; it has hardly been rougher than it was on our "cruises" about S.F. bay the whole trip, except for a couple of days after leaving 'Frisco. We are hoping it will continue to be just as good. I hope you have had as good weather on your ocean voyages as we have, sweetheart. Well, good night precious little darling wife: another day has gone dear. Good night and God bless my perfect little wife.

Aug. 29. The captain and Dr. G. had a good row at last. Dr. G. is about the most aggravating person to get along with I ever saw: he sort of takes delight in doing things underhanded: he bosses my men and says all sorts of impertinent things. Not being of a very motley disposition, I have stood it all cheerfully, and occasionally told Hepburn some of the things he has done, merely for someone to tell them to. Last night I told him another rather mean act of Dr. G's and he said "Why don't you tell the old fool to go to $\mathrm{h} \ldots$ _; this has gone far enough, I am going to tell the old man." I tried to dissuade him, knowing there would be an awful row, but he said he was going to put me in the right light anyhow, so he went and did. This morning the captain sent for me in the cabin. He was ripping mad, and told me he had been telling Dr. G. a few things. He told Dr. G. that his position on the ship was purely that of scientific adviser and that I was the head of the scientific staff on the ship, and that he wasn't going to have any of his officers treated the way he had treated me. He also told him that he must stop ordering my men about: he had nothing to do with them whatever. If anything was to be done, he was to tell me, and not attempt to use my men. The captain said he didn't ask me, he commanded me, if anything more happened to tell him at once, so there could be no misunderstanding. I guess he must have jumped on him pretty hard. All the others are pretty well tickled, as they 
all hate him more or less. Anyhow, things ought to go on swimmingly in the future. Other than then nothing special has happened today; we have been dredging same as ever: by the way, the captain, incidentally took the dredging out of Dr. G's hands, and now runs it himself. Dr. G. wanted to get into Yokohama Saturday night, but the captain said the schedule he made out calls for Sunday, and he sees no reason for any changes, so we will be there Sunday. Well, precious little darling, good night and God bless darling darling darling little sweetheart.

Aug. 30. Dredging all day again. It has been hot the last few days, but not uncomfortably so, as we can wear any old clothes at sea, and don't have to worry about our looks. Last night and tonight we anchored in a little bay between Kobe and Yokohama where it is nice and quiet, and we can get a better sleep than when the boat is rolling about. We had a little excitement today. We learned at Kobe that there was a typhoon down in the Liu Kiu [Ryukyu] islands, just south of Japan. Just before noon the barometer suddenly dropped, and it began to blow, so the captain stopped all work and skipped double quick for a harbor. Everything was made secure, all the awnings were taken in and we were all ready for a time of it, but nothing happened. We got to anchor about 6 , and then the wind died down. They had a typhoon in Tokyo last week that did considerable damage. We have nothing to fear from them, however, as there are little harbors everywhere along the coast which we can reach in a couple of hours, and a typhoon always gives plenty of warning. Well, darling, another day has gone thank God. We have only one stage more of the trip after reaching Yokohama, and then we are coming home. Everybody on board except Dr. G. is anxious to get back. Good night dearest dearest dearest wife, God bless you. Duck's rest dear.

August 31. Dredging as usual all day, with the usual lack of excitement. It has been cooler today, with a nice breeze. I am looking forward to getting more letters from my little darling at Yokohama. I can hardly wait to get there, dearest. If you only knew how I long to see you dear dear dear dear Mary, and what a job I have to keep the homesick business out of my letters. This whole summer seems like a dream dear; as if it wasn't real, somehow; sort of as if I had gone to sleep just a little while after the eathquake and wouldn't wake up until I was with my dear little wife again. Good night precious darling. Another month has gone by. Good night and duck's rest, dearest. God bless my ideal wife.

Sept. 1. We sailed all night last night towards Yokohama, and didn't do much today. We are sailing now, and expect to get there early tomorrow morning. Yokohama will mark the end of another stage of our trip, dearest dearest dearest wife. We have only one more stage now, to go to Sakalin and back, and then we are coming home. Just think of seeing my darling little sweetheart again. Sometimes I get so impatient it seems as if I just had to leave the ship and take the first mail boat back. Well, darling, I will close this letter now so as to get it into the first mail from Yokohama. Good night dearest precious little wife. Duck's rest and God bless you, darling.

With lots \& lots \& lots more love and kisses than ever from your most loving husband

\section{Yokohama, Japan}

Sept. 2, 1906

Dearest dearest dearest sweetheart,

We got into Yokohama at 8 this A.M., and I have just got 2 bunches of letters from you from Florence. Wasn't it sad about that man being killed by the elevator? Do take the very best care of yourself, won't you precious? Remember, you promised. You needn't worry about me, dearest wife, I am taking the best care of myself. Wasn't it funny about meeting Edward Nathaniel Clark in Florence? I didn't suppose he was in Europe. I'm mighty glad your trip is turning out to be so pleasant, darling. Won't it be fun telling each other our experiences when we meet again. I try to tell myself every night that it won't be long before I see my perfect precious little wife again, but somehow it does seem so long. But then, I mustn't get homesicky, must I dear? Good God dear, I do want to see you so badly. Tongue and I went ashore this evening and took some rickshaws and had a ride pretty much over Yokohama. It is quite a European sort of a place. I got a couple of lacquer trays that they serve tea on dearest. They are quite pretty ones, the prettiest I have seen, and I got some chopsticks. The trays cost $\$ 1$ for the pair and the chopsticks 4 cents pair. They are bone, prettily ornamented. I am going to get some clothes made here, dearest, as they only cost half as much as at home, and are tailor-made at that. Lots of Chinese tailors came on board this morning, and the others all got some, and advised me to. I am getting a serge suit, and guess what? Do you remember you said you would like to see me in a frock coat? Well, I thought I had better get one, because I shall need it when we get to Washington, and I can get it here for less than half what I would have to pay at home. Do you think it was foolish of me dearest? They tell me they make these very well here. Well, precious darling little wife, good night and "duck's rest". God bless my dear dear dear wife.

From your most loving

husband.

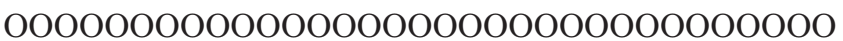

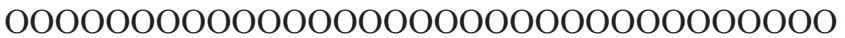

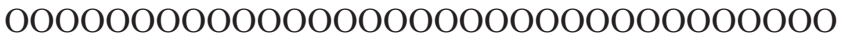

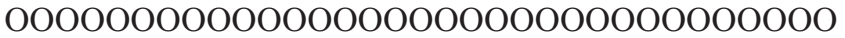

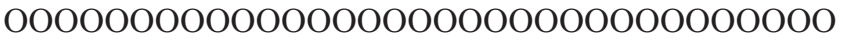

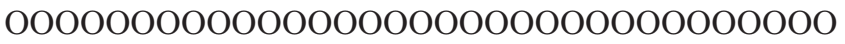




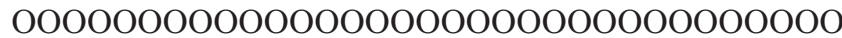
000000000000000000000000000000000 000000000000000000000000000000000

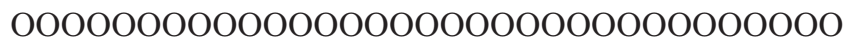
and 10 hugs to each kiss

\author{
Yokohama, Japan \\ Sept. 4, 1906
}

\section{Dearest darling wife,}

Nothing especially exciting happened today. It was rather threatening looking, so I stayed on board all day. Crater and Metters and Hazard and the paymaster went ashore, and Crater announced his intention of buying a couple of dollars' worth of stuff: he didn't know exactly what, and he didn't care: he merely had a feeling he said, that he had to spend the money: so he bought a pop-gun, and a toy pistol, and a small Jap. lantern on a stick, and a great paper chrysanthemum in a little flower pot. He lit the lantern and pinned the chrysanthemum, pot and all, to his lapel, and went about that way, occasionally letting off the pistol. Metters was mad as anything. Crater always acts like an overgrown kid when he gets ashore. It sounds on the boat as if there were millions of crickets everywhere. Here in Japan they catch cicadas (you know the cicadas that make such a trilling noise in the trees in summer at home?) and put them into little wooden cages. There are lots of little booths about Yokohama which sell nothing else; you can imagine what noise they make. Well, one of the sailors bought some of them and brought them on board and hung them up in the forward part of the ship, and they are now all chirping their very best. Well, precious, it is rather late now, so I shall have to close. I shall write a nice long letter every day dearest. Good night dearest dearest dearest dearest little sweetheart “Duck's rest and God bless my dear dear wife.

From your most loving husband

\section{Yokohama, Japan \\ Sept. 4, 1906}

Dearest dearest dearest Sweetheart,

What do you suppose I did today? Had my picture taken. I went ashore and made a tour of the various photographic places and finally found a nice one, where they make colored photographs exactly like the best ones at home for $¥ 6$ or $\$ 3$ a dozen. I had a couple of exposures taken, and am going to see the proofs tomorrow. I wonder what you will say precious when you see a picture of me with a beard (Fig. 5)! You must write me dearest and tell me if you want me to keep it or to shed it before I get back. We are going to stay here until the next boat with mail comes in. Dr. G. wanted to clear out as soon as possible, but the capt. said he would wait a couple of days more for mail: he didn't see any reason for waiting almost up to mail time and then clearing our just in time to miss it, as we did at Vancouver. The capt. is taking things pretty much into his own hands now a days, to the great relief of everyone. A funny thing happened today. You know we had a Jap. on board, Sindo, who is ashore in Japan with Dr. Snyder collecting shore fishes. Well, Dr. G. and Dr. S. went up to find him there to act as interpreters for them. What was my surprise to see him come aboard about 4 P.M. Snyder had come up to the boat as soon as we came in, but they hadn't money enough to pay Sindo's hotel bill so he had to stay until it could be sent him. It was sent yesterday, with instructions to go to Tokyo; but Sindo was so anxious to see the ship again, he gave them the slip and came to Yokohama. My! But they will be mad! Poor Sindo has been 20 years away from Japan, and has no use for it now. He is awfully homesick to get back to the U.S. Nothing here is as he remembers it when he was a boy here, everything is changed, and he says, for the worse. Well, good night my precious little darling wife and sweetheart. One day more has gone by. God bless you dearest dearest dearest girl.

With heaps of love and kisses

From your most loving husband.

Yokohama, Japan

Sept. 4, 1906

Dear mama,

Just received your letter of Aug. 8 this morning. I am awfully sorry to hear you have been having trouble with an ulcerated tooth again. I shall look up some skins for Ros [Rosamund] when we are up in Sakalin. There were lots of the most beautiful blue fox skins in the Aleutians for $\$ 18$ each you ever saw, but I thought, considering the locality, it was rather high. The natives had a number of skins which they swapped off for old clothes \& chunks of lead, etc. with the officers of the ship, but I was rather skeptical about them. My doubts proved to have been well founded; for when we got to Hakodate and the officers sent their skins ashore to be tanned, they learned they were skins taken from foxes found dead and the hair came out in chunks. I got Mary 3 cross fox skins at Hakodate which are the finest I ever saw: they are beautifully tanned and all ready to make up. They had a lot of sable skins in Petropaulski for $\$ 50$ each, which was absolutely the lowest they would take. However, there may be some nicer skins cheap at Sakalin: anyhow I shall keep my eyes open. They had the finest tiger skins I ever saw at Hakodate for sale: fur about 5 inches long. It came from Sakalin. I am looking for one for Ned Holmes. They wanted \$2400 for them, Mexican, or $\$ 1200$ U.S. Everything is going on finely on board: everybody well and cheerful, but all anxious to get back. We had 3 men desert recently, all bad characters, whom we are 
glad to be rid of. Nothing else has happened. The weather is fine now, nice and cool. It has been quite hot until the last 2 or 3 days. Give my love to everybody.

Aff. A.

\section{Yokohama, Japan \\ Sept. 5, 1906}

Dearest dearest dearest sweetheart,

Still here in Yokohama. I stayed on board and read all day, so I am afraid I haven't anything very exciting to write. It is lovely and cool now: the hot weather has ended. Some of us on board rather have our doubts about going up as far as Sakalin because we read in the paper this morning that the port of Newchwang was expected to be closed by ice pretty soon, and New-Chwang is way south of Sakalin. This captain is a most cautious individual, and refuses to take the boat into any place where there is any sign of ice. There are a lot of boats in the harbor here now. Two North German Lloyd steamers, one from Bremen and the other from Australia came in this morning, and a Dutch steamer from Java. There is a yacht here from S.F. with a scientific crowd on board studying magnetic variation in the $\mathrm{Pa}-$ cific. She used to be a "missionary boat"; that is, carried missionaries about the south seas, and did a thriving piratical business for their benefit; consequently, like their missionary boats, she had anything but a good character. Tell your mother and Betty I am going to get them each a present here. I don't know what it will be, but I guess the way I decide will be to bring what I have home, and let you pick out the two things you care for least: don't you think that will be a good way? I am so impatient to get off to Sakalin I just don't know what to do. Just think, precious: the last stage of this trip. The whole trip has been sort of a grisly nightmare dearest: all unnatural and unreal and horrid, precious: but it has showed me more clearly than anything, how my whole existence is wrapped up in, and all my happiness dependant [sic] on my precious dearest ideal wife.

With lots \& lots \& lots more love \& kisses

From your most loving lover

\section{Yokohama, Japan \\ Sept. 6, 1906}

Dearest dearest wife,

Nothing especially thrilling happened today. Tongue and I went ashore for a walk this P.M. The first object we met was Metters, drunk. Of course he froze onto us, but we managed to shed him pretty quick. The more I see of Metters and Prine and Hazard the less I like them. They are positively disgusting. Crater gets happy quite often, but is never obnoxious, simply ridiculous. You can't expect anything better from people of their class, anyway. I bought you a fine, heavy silk shawl today darling, beautifully embroidered, the prettiest I ever saw. It cost $7 \frac{1 / 2}{2}$ yen or $\$ 3.75$. I also got a set of 6 big and 6 little shirt waist buttons of Satsuma ware, awfully pretty and odd things, with sprays of wisteria on them. I looked at the proofs of my pictures today. They are the funniest things. I do wish I could be there when you first see them. I am going to send you half a dozen first thing, darling. If you like them you can give one to your mother, one to my father, one to my grandfather, and one to Johnny, and another to Uncle Charles: at least, I should suggest those, darling: of course you can distribute them as you see fit. I think it is fairest to send them all to you, my precious sweetheart, so if you don't like them you can just destroy them and nobody will be the wiser, see? I wouldn't want anybody to have any pictures of me you didn't like, of course, dearest. It has done me worlds of good to write to you this evening, precious little dear; this has been the homesickest day I have ever had. I never sort of realized as much as I have on this trip what my darling darling wife meant to me: how really and truly she is just all the world: just everything. Well good night precious darling and "duck's rest." God bless you dear.

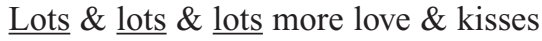
from your most loving husband

Yokohama, Japan

Sept. 7, 1906

Dearest darling precious wife,

It has been kind of a mean day today, drizzly most of the time. Tongue and I went ashore for a little while this P.M., but didn't stay long. Metters is complaining that he has caught the tourist habit, and has asked the doctor for some remedy. He has an attack of the curio habit too: he bought \$230 worth today: not that he wanted them, but like Crater, he sort of had a feeling he wanted to spend some money. He was going to get a tea set with a monogram on it, as he expects to get married this winter, but he doesn't know what monogram to have put on, as he doesn't know whom he is going to marry as yet. I got you something else today precious, a set of a dozen chocolate cups and saucers. Each one has a procession of Jap. girls on it, in native costumes, and each with a big umbrella. The color of the dresses is different on each cup, although all on each individual cup and saucer are the same. Besides this, each cup has a monogram MWU in gold on the inside, where you will see it when the cup is half empty. They make very pretty monograms here. How do you think you will like it, dearest? It cost 75 cents to have the monograms put on; doesn't seem high, does it? Do you know these cloisonné vases? They make them here, and I am going to get a pair made with your monogram worked into the design dearest. It is a thing you never see at home, and ought to make people awfully envious. These cloisonné vases are just the 
prettiest things. I shan't get anything expensive, precious, you needn't worry. I am so anxious to see what you will say when you see the things I have got for you dear dear dear wife. The best of it is that if you don't like them, dearest, we haven't lost any money, as we can always sell them for more than they cost. Well, good night, dearest little darling sweetheart. God bless my dear dear wife and keep her from all harm.

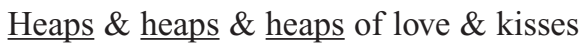
from your most loving husband

\section{Yokohama, Japan \\ Sept. 8, 1906}

\section{Dearest dearest sweetheart,}

I took my first real round of the shops here today, and got a few things for you precious I have been intending to get for sometime. I also got a couple of shawls, one for your mother and one for Betty. They are silk crêpe and prettily embroidered. I paid $\$ 3.50$ for the pair; one is light blue and the other white. They aren't really as good as the one I got for you the other day, but are mighty pretty for all that. The main difference is that they are much lighter in weight. I also got a pair of handsome cloisonné vases and some (2) little Satsuma ones, which are the prettiest I have seen. The best thing I got dearest was a nice kimono for you. The doctor advised getting one here, as they are very cheap. I do so hope you will like this one. It is heavy and warm, so you can use it as a dressing gown dearest. It is navy blue, with chrysanthemums in natural colors on it, finely embroidered. Most of them have so much embroidery on them they are spoiled, but this has just enough I think. Anyhow, darling, if you don't like it we can sell it for lots more than we paid for it. The comparatively small amount of embroidery on this one is compensated by extra heavy silk. It ought to last indefinitely. It certainly is a beauty; just as soft and nice as can be. It was the cheapest they had, but the cheapness, was due, as I just said to its not being, like most of them, a solid mass of embroidery. I am just dying to see you dressed up in it darling. I have got everything now I feel justified in getting, dearest. I wouldn't of course have gotten nearly so much, but you see that trip to Europe saved us considerable, and things I can get here are so much cheaper. The vases and things like that we will need for our home darling, and of course a teaset and a dozen coffee cups will be in constant use. I have thought a long while before buying everything dear dear sweetheart, and when you see the things I think you will agree that the money hasn't been wasted. I have saved a lot too precious by staying on the ship when we are in the various places, and not visiting the neighboring towns as the others did. Railroad fares mount up, dear, and I do feel so much happier to be able to bring you back an extra present or two, which will be of lasting value, rather than to be selfish and take trips to Tokyo, or Kyoto or Osaka, places every tourist sees. I do love you so much dearest dearest little girlie: I am trying my best to do what will please you most dear, and trying not to be selfish. I am so anxious to hear what you will have to say about the things I bought. I can scarcely wait. They make quite a lot now, don't they precious? Metters is complaining now of having the curio habit: you know he had the "tourist habit" the other day; went around everywhere to see things he didn't care anything about: now he has a buying mania. He got an extremely fancy embroidered silk kimono today, from about $\$ 50$, and is now wondering what to do with it. He has bought a teaset and various other things too, for no special purpose, apparently, except that, like Crater, he gets a feeling he has to spend some money. One of the sailors got stuck at a new game this morning; he bought a teaset for 5 yen $(\$ 2.50)$, and then showed it to a Jap. who came on board and asked him what he thought it was worth. The Jap. said 80 sen (40 cents). The sailor didn't believe him, but the Jap said to give him a yen (\$.50) and he would get one just like it. He gave him the yen, and hasn't set eyes on him since. We are going to leave Tuesday morning for Sakalin, and then, thank God we will be on the last stage of our journey. Everybody is hoping Sakalin will be frozen solid, so we will have to come back: anyhow we probably won't stay there very long. Tongue has gone up to Tokyo for over Sunday. Torrey leaves for S.F. tomorrow on the "Mongolia". The "Hong Kong Maru" from S.F. gets in Monday, and I am anxiously looking forward to some more letters from my darling little sweetheart. How dear and brave you were through all the earthquake business precious; no other girl that ever was could have been half so brave. You are just the noblest and best and bravest and dearest little wife in the whole world. Well dear dear dear Mary, good night and “duck's rest" precious, God bless my darling darling wife.

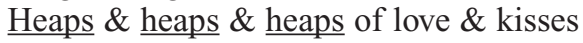
from your most loving Austin

Yokohama, Japan
Sept. 9, 1906

Dearest dearest sweetheart,

Nothing especial happened today as it is Sunday, and it drizzled all day so it wasn't at all pleasant on shore. Metters' silk kimono came today and he is wondering where he is going to get the cash to pay for it. He went ashore this A.M. and bought a beautiful silver umbrella handle. When it was put on, he decided it was too good for the umbrella, so he had it recovered with extra heavy silk. Then it struck him the framework was shabby, so he had a new framework put in, and is bemoaning his luck now, because the whole thing is going to cost him about three times as much as a new umbrella would. Dr. Torrey's steamer is in today: 
he leaves tomorrow for Frisco. We are going to coal tomorrow and leave the next day for Sakalin, for the last stage of our journey, thank God. I got my pictures this evening, dearest, and am sending you half a dozen with this letter. The "Hong Kong Maru" from Frisco comes in tomorrow, and I am anxiously looking forward to some letters precious. I have just time to close this letter and get it into the mail going by the ss "Mongolia", which closes tonight. Well good night dearest precious little sweetheart, and "duck's rest". God bless my dear dear dear wife.

From your most loving

\section{Austin}

P.S. Heaps $\&$ heaps $\&$ heaps of love $\&$ kisses dearest dearest little girlie

\section{Yokohama, Japan \\ Sept. 10, 1906}

\section{Dearest darling wife,}

It has been misty and rainy all day today. Nothing much exciting happened. I was ashore all the morning doing errands and in the P.M. the doctor took me to a cloisonné factory where they will do things for us at wholesale prices. He is having lots of work done there. He has bought so many curios since he has been on this trip that he has had to get a 3 months advance in pay. Do you know what cloisonné is dearest? It is metal but all enameled so it looks as if it was porcelain, with the design outlined with very fine gold or silver wire. It is usually quite expensive. This man does it for about half the cheapest retail prices. I am getting a couple of vases made for you, precious, with the prettiest iris design on one side, and a monogram with the letters MWU on the other. They are a pair and will be almost alike, with just enough difference in the design to make them pretty. One of the chief petty officers on board designed the monogram. It is going to be done in three colors and will be something like this only much prettier of course.

I also ordered a solid silver nap-

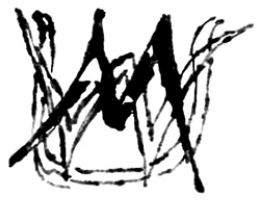

kin ring of cloisonné ware (price

87 cents, not much above the price of the silver) with a dragon and monogram on it. Your coffee cups came today, precious. They are as pretty as can be. They have a monogram inside the rim where the black spot is so as not to interfere with the design. They made awfully pretty monograms; real fancy ones in gold and red. I can hardly wait to hear what you will say about them dearest. We are waiting now for the "Hong Kong Maru" from S.F. for mail before we leave for Sakalim. I am awfully anxious to get away, as this means the last stage of our journey has begun. They say here the weather up there is fine now; the best time of the year. Be extra careful of yourself dearest little precious darling. It won't be so very long now before we meet again dear dear wife. I mailed 6 pictures of myself to you today dearest. I hope you get them all right. Well good night precious little sweetheart, and "duck's rest". God bless you dearest.

Heaps \& heaps \& heaps \& heaps of love and kisses, from your most loving Austin

Yokahama, Japan Sept. 11, 1906

Dearest dearest dearest sweetheart,

The "Hong Kong Maru" from S.F. came in this A.M. about 10 A.M., but the mail hasn't been sorted yet. Tongue has been ashore several times after it. We shall probably get it tomorrow morning. It is an especially big mail, as the H.K. Maru is bringing, besides our own, the mail of the ss "Manchuria", which ran ashore a couple of weeks ago at Honolulu. I am so anxious for a letter from my precious little wife I don't know what to do. I bet I don't sleep a wink tonight. I do love you so dearest. Dr. G. told me today he got an official letter a few days ago saying they intended sending me to Washington as soon as the ship got back. Isn't that great? Dr. G. himself wrote on a while ago suggesting that I was a useful person to have at Washington, and that I was wasted on board the Albatross. I didn't know till today he had done it. Wasn't it good of him dear? Won't it be fun living in Washington next winter? I don't see why we should ever have to be separated any more dear wife. We must plan another honeymoon darling, mustn't we? Won't it be fun hunting up apartments in Washington, though? This is the best news I have heard for quite a while precious. I only hope I get a raise in pay so that we can afford to have a little something all our own, dearest. Wouldn't that be just heavenly? Anyhow I hope the time will come soon, darling. I would give just anything to be able to do it. Just think what it would mean to us dear. I only hope when we do have it takes after you, darling the finest and noblest and bravest and dearest little woman in the whole world. The paymaster is happy today: he got word that he was raised to the rank of lieutenant, so that he now has two stripes instead of one. He was an ensign before. We have a new boy we got here to take the place of that grinning thing that ran away in Kobe. He is quite decent. There was a hubbub this morning. Two of the engineers and all the firemen were discovered to be drunk, and, as none of them had been on shore, suspicions were at once aroused. The engineers were lined up aft, and given an awful dressing down, and then Mr. Hepburn went down into the steerage and searched their rooms, being rewarded by finding 3 bottles of gin, one in each room. The firemen, it appears, had been having quite a tea-party in the fire 
room with some whiskey some of their friends had brought aboard. At Kobe I discovered old Jacobson and a sailor named Burke drunk in the lower laboratory, with a bottle of whiskey, which had been smuggled aboard. I rustled them up on deck quick, but didn't tell on them, because there is no use making trouble, and they were only harmlessly drunk. I was fixing up one of the nets on deck one day and found a bottle of whiskey hidden in it, which I hove overboard. It is funny what the men will do to get booze. Their one desire is to keep full all the time. However most of our crew are young chaps and pretty straight and reliable: far better than the average navy crew, and Teed is mighty good at keeping order. Our two worst drunks ran away at Nagasaki. Old Jacobson and one of the firemen are the only bad ones left. I forgot to mention Metters: he is full a good part of the time in port, although he is by far better than the other two watch officers (Prine \& Metters). He was once a gentleman, as he says, a thing which neither Prine nor Hazard ever were or ever will be. It is funny, but when he gets full, he sort of loses his roughness, and becomes more of a gentleman than he is when sober, which shows it is born in him. Metters got the silk kimono I told you he bought today: a lilac one, all covered with embroidery. He is now wondering how he is going to pay for it. Well, dearest, we start tomorrow morning on the last stage of our journey thank God. We are going straight up to Sakalim (calling in at Hakodate on the way, where I am going to pick up our bear skin, which is being tanned). Good night and "duck's rest" dear Mary. It won't be so very long now before I see you again dear sweet wife. God bless you, my very precious little sweetheart

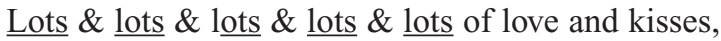
from your most loving husband

\section{Yokohama, Japan}

Sept. 12, 1906

\section{Dearest dearest wife,}

It is still raining like everything and blowing harder than ever; it begins to look doubtful if we get out tomorrow. I went ashore this P.M. to post the letter I wrote this morning so it will go in the "Aragonia" which is due to sail tonight for Portland, Oregon. Nothing special has happened: we just loafed around and read a bunch of newspapers Crater got on shore. They are all old papers, but news to us. That was an awful earthquake they had in Chile, wasn't it? I think we are satisfied with the San Francisco one, aren't we dearest? We learned today that 40 fishing junks have gone down off the entrance to the bay. The fishing junks here are the flimsiest things you ever saw: anything would knock them over. They are very high out of the water and have no decks, so if the sea sloshes into them, down they go kerplunk. The captain is going to wait here until the weather gets more settled: the wind is from the north, just the di- rection we shall have to go, so it wouldn't pay us to try to buck against it. None of the steamers in the harbor left today, owing to the wind. I hope we have to stay till Saturday, darling, because there is a mail due from the States then and I do so want to hear from my precious little Mary. There is one thing, dearest: our prolonged stay here won't keep us from getting back any sooner, because we have to start back by the 1st of Nov. anyhow and we might just as well spend the time lying snugly here inside the breakwater as at sea. By the way they have a new tremendous breakwater here, costing many millions which was paid for by the fines exacted from drunks from the foreign ships. Quite a scheme, wasn't it? Well, precious little darling, good night and "duck's rest" dear: one more day has passed. God bless you my dearest, dearest wife.


from your most loving husband

\section{Yokohama, Japan Sept. 12, 1906}

Dearest dearest sweetheart,

Just got your letters from July 26 to Aug. 1. You just can't imagine how glad I was to get them, precious. I do love you so much darling and I just realize it more \& more all the time. I am mighty glad dearest that you are spending the summer in Europe, for just the reasons you say dear. It must make the time go lots quicker seeing all sorts of interesting things and going around to all sorts of interesting places than if you had just stayed at home. It will be an immense advantage to you precious to be able to talk with people about Europe, too, because all well-educated people practically have been there. After your experiences in Europe and in California you can certainly hold your own with anyone darling. You saw how I was at Mrs. Rossiters dear: cultivated people are inclined to be a little distant to people who have never traveled any. Remember how Claverley loosened up when we sprung Europe on her? Most aristocratic people are that way. It will be lots easier for us to get a really first class circle of acquaintances in Washington if we can talk Europe. Do you remember Mrs. Hepburn sprung Europe almost the first thing? It sort of seems to be almost a preliminary mark of gentility, and a necessary step for entrance into really decent society to have been to Europe. I am so glad you got the chance, darling. It was awfully good of your mother wasn't it? I don't mean to infer dearest that we would have had any trouble if you hadn't gone darling, you see what I mean don't you dear? It just makes it lots easier for us that you did go. The sweetest and dearest and prettiest little woman in the world is just bound to cut a figure anywhere darling when people become acquainted with her but [damaged - illegible] makes it easier as it is. I shall never forget how Ned Holmes and your cousin Wendell received me, dearest because I was the husband of the 
dear little woman they liked and respected so highly. When we are in Washington next year darling, we will get lots of books on Europe and Japan and read them to each other, and you can explain to me all about Europe, and I will explain to you all about Japan. Won't it be just great dear? Won't it be fun? I do so hope we can do what I mentioned about the "little something" too dear Mary, that is darling, if you would like it too; I would feel so happy if we could. Wasn't it funny about Prentiss being engaged? I wonder how they all are and if Uncle George has got his business together again. This post office is the queerest. Tongue went ashore at 8 this morning, but only got a few letters: the rest hadn't been distributed yet. It is raining great guns today, and the storm is reported outside, so we are going to stay until tomorrow. The battleship Wisconsin came in last night. Most of the men on this ship have served on her. The paymaster was a common sailor there once. The transport "Lawton" and the supply ship "Supply" are also in, so, with us, it makes quite an American fleet. The storm season is practically over now they say, and we ought to have good weather from now on. We have had wonderful weather so far. The summer is about over now, and it has been quite cool the last few days. I forgot to say that the paymaster loosened up last night and treated everybody to champagne at dinner on the strength of his promotion. He and the doctor have been making up to each other gradually for the last three weeks, and are now on good terms again, to the great relief of everyone. That has been the only break between the officers the whole cruise: I believe it establishes a record for the ship: there are usually all sorts of rows, I believe: it invariably happens when a number of men are shut up together for any length of time. Somehow it seems to be a part of human nature. Everybody looks on this trip as quite remarkable. It [damaged - illegible] happens that all the [damaged - illegible] tempered and cheerful. Well, precious little darling wife, au revoir, dear; God bless my dear dear Mary. It doesn't seem so long now before we meet again, does it dear? I will write again tonight if we are still here.

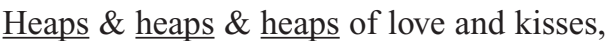
from your most loving Austin

\section{Yokohama, Japan Sept. 12, 1906}

Dear Papa,

Just received your letter of Aug.14. I think it is a good idea for the Ropeses to come back east. From what we hear Cal. must be in pretty much a mess now, what with all the strikes and labor trouble. Berkeley isn't much of a place, either. I am glad Charlotte is "perfectly well": I imagine the earthquake had a lot to do with it: it scared her so I don't think she thinks of anything else yet. They must be having all sorts of labor troubles in S.F. from what we hear: the ss "China" came in the other day without cargo because of a longshoreman's strike. It has been hot out here up to about three days ago, when it got rainy and has rained more or less ever since. It is nice and cool now. We are waiting here for mail to be distributed at the P.O. The "Hong Kong Maru" from S.F. arrived yesterday, bringing her own mail and that of the "Manchuria" which ran ashore at Honolulu a couple of weeks ago, and the combined mail seem to be rather too much for their P.O. to handle. We have only got a couple of dozen letters so far for the whole ship. Everybody is well and cheerful on board, but all are anxious to get away, as the temptation to invest in curios is too strong. All the officer rooms are well stocked curio shops in themselves now, and there are sundry boxes and barrels of curios stored in all available parts of the ship. I am going to keep my eyes open for some furs for Ros when we are up in Sakalim. I got a fine set of skins for Mary up at Hakodate, about the finest I ever saw. I also got a bear skin for a rug at Petropaulski about $9 \mathrm{ft}$. long and 11 across the forepaws, with enormous claws. It cost 15 roubles $(\$ 7.50)$. I am having it tanned at Hakodate, and am going to pick it up when we call in there on the way to Sakalim.

Aff. A.

Yokohama, Japan

Sept. 13, 1906

Dearest precious sweetheart,

Still here: stormier than ever. The "Hong Kong Maru" was supposed to sail yesterday for Shanghai, but is still here. No ships have gone today, but one, the "Nippon Maru" came in from Hong Kong, bound for Frisco. We haven't done anything at all today, only loafed around and read the papers. At lunch, they had some new fangled pudding of Hazard's for dessert. They had ordinary sauce for it, but Metters said next time he would suggest having onion sauce; it would disguise the taste better. At dinner we had rice croquettes, which Hazard informed us was the result of the failure of the cook to construct a rice pudding so he made croquettes out of the remains. Hazard is now caterer, having superseded Crater the first of this month. Dr. G. told me today dearest that he had just received another letter from Washington saying that my transfer had met with approval of the assistant commissioner and told me he had no doubt that it would go through. Isn't that simply great, dearest? Won't we have fun in Washington next winter? Won't it be fun looking up apartments and things? I wonder where we will live? I will take mighty good care, precious, not to be sent out on the boat again. I'm just nev-

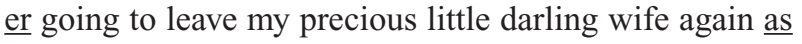
long as I live. Won't it be great reading to each other and spending our evenings together as we have planned precious? and telling each other all about the things we have seen. I can hardly wait to get back darling. The paymaster amused us all this morning by appearing in lieutenant's uniform; He sent all his clothes ashore yesterday and had 
them altered. Rather quick work, wasn't it Well dearest, dearest precious little Mary good night dear and "duck's rest". God bless my perfect little wife and [torn away] her always safe.

[torn away] lots\& lots [torn away]

Sept. 14. Dearest dearest sweetheart,

The wind had gone down this morning and it had stopped raining, so we got away all right about 9 o'clock. We found a very heavy swell outside, which made the boat roll like everything, but it wasn't especially bad, not nearly as bad as going up to Seattle. Well, darling, we have started on the last stage of our trip at last dear, and when we see Yokohama again we will be homeward bound. Just think of the fun we are going to have in Washington dearest? Won't it be great? I think perhaps dearest I may get orders out here to come east as soon as we get in. In that case precious I shall take the first train back home, so it will save you the long trip across the continent. Anyhow dearest I shall cable from Honolulu and let you know what I hear there. We aren't going to do any dredging until we reach Sakalin, so I shall have an easy time for a week or so. We heard yesterday that they had snow last week near Hakodate, so perhaps we won't stay very long in Sakalin. By the way, Sakalin is the best place for wooly tigers, so perhaps I can pick up one there for Ned Holmes. Well, good night precious little darling wife. "Duck's rest" and God bless you dear.

Sept 15. Rolled like everything all last night so we could scarcely sleep. A barrel of beans got loose in the hold and crashed all about for a couple of hours, till it was captured: then a $60 \mathrm{lb}$. sounding shot got loose in the lower lab, and started rolling all around there, making an awful racket. Hansen went down after a while, and found it standing up quietly in a corner. He said it had got so tired of rolling around it couldn't roll any more. This morning the surgeon and I were sitting up on the poop, and $360 \mathrm{lb}$. sounding shot jumped out of the racks all at once, and began hopping and dancing all around. We made a quick dive for shelter, and a couple of sailors came up and caught the shot. It is rather exciting work catching a 60lb. cannon ball when a ship is rolling heavily. Metters had a potted plant in his room, on his bureau, just at the head of his bunk. Last night it over-turned, and spilled all the dirt out all over his face. Prine has a bookcase in the same situation, and the books all came out one at a time, so as to make it more impressive. We haven't done anything today except try to make up for the sleep we lost last night. The trip up to Sakalin seems to be anything but popular on board. The people in the ward room have been discussing ways and means of getting out it, but none of the ideas seem plausible. The announcement of a fall of snow just north of Hakodate a few days ago did lots to raise their spirits. Almost every meal someone says, with the greatest feeling, imaginable "Dear old Sakalin" which always provides a roar of laughter. However, I guess we are really going: but I understand that we are only going to visit the southern end of it, and then come south again. Dearest Mary, this is the very last stage of this trip. I am so glad. Somehow precious, precious little wife I can't seem to get used to being away from you at all. I keep wanting to see you worse and worse all the time dear. The longer we stay out the more homesick I get darling: do you think I am too silly? Dearest, nobody ever loved his wife half as much as I do you Mary, and I realize it more and more every single day. When we get together again we just won't ever be separated again, will we precious. Well, good night dear dear dear wife, and "duck's rest". God bless my darling Mary.

Sept 16. We had the sails set all last night, as there was a good breeze. There was considerable rolling, too, although it wasn't so bad as night before last. We learned today that we are going into Hakodate tonight for fresh provisions, and then up to Otaru for coal. After that we are going to cruise about the southern end of Sakalim for about two weeks, and then going to Iturup, just south of Simushi in the Kurils and them back to Yokohama. I would give just anything to be able to see you now dear dear wife. I didn't realize the separation would be so hard to bear. Don't think me foolish Mary, but I do love my little sweetheart so much. Dear Mary, you know I have always told you I was going to do the best I could for your sake, don't you? I hope you won't think me too conceited dearest, but I have succeeded here. Dr. G tells me I am much too good for the boat, and, as I told you, has got the Fish Commission people to recall me to Washington. He is just as nice as he can be to me. The captain for some reason or other thinks a lot of me too, so I am having a very pleasant time; in fact I understand I am getting on infinitely better than any of my predecessors. For some strange reason I am very popular with the sailors too. Several of them have asked me if I wanted anything special done to be sure and ask them. Old Jacobson told me once (when he was confidentially drunk) that I was even better than Mr. Chamberlain, who was formerly his idol. Just see what an enormous influence you have been over me precious wife to make me that way with everybody. I am going to devote my whole life dear sweetheart to try and become worthy of my darling little treasure, the best and finest and bravest little woman in the whole world. I can't see at all why you should like me darling, but I hope sometime in the future to be a somebody for my dear dear wife's sake. I am going to bind all my energies to that end dearest. well au revoir dear dear dear wife, I must close now so as to mail this tonight in Hakodate.

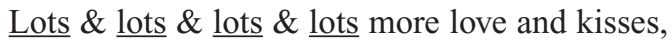
from your most loving Austin 


\section{Hakodate, Sept 18}

Dearest darling little sweetheart,

I just got the nicest bunch of mail from you this morning precious, six letters and two postals; all those you mailed from England and two from France. I suppose they must have got here just after we left and they kept them here until we got back. I was so glad to get them dearest, I have been wondering where they were, as you mentioned things in them in your later letters. Isn't England just the prettiest place you ever saw dear? So homelike and peaceful looking. We just must visit it together dear, mustn't we? I never went to Canterbury dear; we stopped in London, and them went and stayed in Salisbury for a while; or I think perhaps it was the other way. We took side trips to Oxford and Windsor Castle from London. That train wreck at Salisbury did give me an awful scare for a while darling, but I looked up the card you sent me and found you couldn't have possibly have been there: however, I wasn't entirely easy until I got your letter from Paris dear. I am glad you are getting pictures, darling. They are the most satisfying things a person can get I think; you can't ever get tired of them, and they always mean so much to you. Don't you think so dear? So you heard Caruso did you? I understand he is pretty fine. We shall have to take in some grand opera next winter, won't we dearest? Won't it be just fun going to theatrics and things together dearest Mary? Somehow I never could enjoy any plays or anything unless you were with me darling; and I am sort of afraid dear that when we go to a play the nicest thing from my point of view is that you are with me, and I don't much care what the play is. You will have to educate me up to grand opera dearest next winter. I only hope I won't be too dense. So Aunt Mary is coming east, is she? I should have thought that they would have got used to quakes by this time: ought to have had enough experience with them anyway. We hear rather bad reports from S.F. and understand that there are all sorts of strikes and things in progress. I saw by the Yokohama paper that troops had been ordered there. I wonder what it looks like now? I think dearest that I may get my orders to come east either at Yokohama or Honolulu, in which case I shall come back just as soon as we get in. I hope I do precious, as that would save you the dismal journey across the continent. Anyhow dearest Mary, I shall cable you what to do from Honolulu. I got a letter today from Mr. Henshaw in the Biological Survey at Washington. He says that next year they expect to take on some people in the B.S. at Washington, and he wants me to be handy. Isn't that great, precious? I got our bear skin today, all nicely tanned. The skin side is as white as snow, and just as soft as [damaged - illegible] tanning cost $\$ 1.75$ : wasn't very high, was it? ...[torn off]...bear skin you ever saw, and will make the [damaged - illegible] see we sent 6 skins ashore to be tanned all at once, [damaged - illegible] made it much cheaper: one alone would have cost \$5. Dr G. went ashore this morning dear to ask some questions about the possibility of a trip to Sakalin at this season. There is a rumour around now that we are not going up there, at which everybody is quite delighted. We understand we are only going around the northern end of Hokkaido (or Yezo), and then to Iterup in the Kurils, getting back to Hakodate in about 2 weeks. I don't know how much truth there is in it, but that is the report anyhow: Hazard and Prine swear it is true. The Paymaster is the dentist on this craft: I don't know where he learned about it, but he seems to know quite a lot. Hanson had a bad ulcerated tooth the other day; sore as anything, and his face all swelled up, and Pay volunteered to pull it. He got Hanson down in a chair in the lower lab and adjusted the forceps, and gave just one yank: Hanson let out an awful yell and lit out: he preferred the tooth ache to Pay's method of painless extraction. By the way, we saw a relic of the Russo-Jap. war in Hakodate; the Russian cruiser "Novik". The Japs are patching her up for their own use. She was shot up in Sakalin, and then blown up, but they raised her and towed her here. She is in an awful state: no smoke stack, and all shot holes. She was one of the fastest ships in the world, and could go 26 knots, or about 31 miles an hour. The old Albatross has to hustle to make 7 knots. The Novik could go from New York to London in just a little over 4 days. We are having more or less fun today: everybody except Burke (the Stanford Student) and myself has an aggravated case of the belly-ache, due to eating some bad corned beef. Burke and I didn't eat any, so we escaped. Hepburn and the doctor were hit the worst. The weather now is cool and nice: sort of last of September weather at home. You can be sure it is appreciated after our sweltering in the Japan sea and around the southern part of Japan. I do wish dearest that I could write dear and interesting letters as you do darling: my letters seem all so stupid and uninteresting, and yours are so simply dear. Wasn't it funny meeting Hubie and Edith on the boat? You must have been awfully surprised. I headed this letter Hakodate without thinking: we left there at 10:30 this A.M. and are now going up the west coast of Hokkaido, bound to Otaru for coal. We are going to dredge tomorrow and the next day, and get into Otaru the 21 st. Well, dearest, another day has gone, and we are really beginning to put the finishing touches on our work now. When we start toward Yokohama again we will be practically homeward bound. Oh I do so want to see my darling little wife again I can hardly wait. What wouldn't I give for just one little kiss from my dear darling little sweetheart! Well, goodnight sweet little wife and "duck's rest" dearest dearest dearest Mary. God bless you dear.

Heaps \& heaps \& heaps \& heaps of love \& kisses, From your most loving Austin 
At Sea

Sept. 19, 1906
Otaru, Japan

Sept. 20, 1906
Dearest dearest sweetheart,

We steamed out about 17 miles from Hakodate which took us until 4:30 this morning, and then stopped and began dredging at 8 . There were about 4 separate thunder storms at 7 in the distance, and it was dark as pitch all around except where the boat was; about half past 7 it began to rain, and at 8 it was raining cats and dogs. Of course that didn't interfere with the work any, as we just put on our oilskins and paddled round cheerfully as ever. There were about half a dozen little whirlwinds in sight of the boat all at one time, all of them about a ship's length across. They caught up the water and lifted it way up in the air, so that when you saw them against the sky they looked like heavy vertical fog banks; or if you saw them against a black cloud they seemed all white like steam. If they had been a little higher and bigger they would have been nice water spouts. It cleared off about noon, and has been perfect since: all sunshiny and cool. A little bird took refuge up under one of the sails during the storm, and later flew in under the dredging engine, when Hanson and I chased him into the lab and caught him. The men all chipped in $\$ 1$ and bought a gramophone at Yokohama; it was a beauty: one of the clearest I ever heard, but it got out of order today somehow, and Buck had eaten up all the directions and descriptions which came with it, it can't be fixed. We got heaps of shrimps in the net today, so we had a big mess of them for supper. Buck is especially fond of shrimps. We had a specially fine dinner tonight (Hazard is certainly a swell caterer) to the great disgust of the invalids, who groaned as every new course came on. The doctor was pretty sick today, and spent most of the time in bed. Hepburn was pretty bad, too. Tongue and Pay are miserable, but Prine and Hazard are about all right. Metters, who ate more of the corned beef than anyone else, wasn't sick at all: neither was Crater, who ate a lot. Burke and I, as I wrote you dearest, didn't eat any at all, so had no trouble. We anchored for the night in an obscure town between Hakodate and Otaru, of which I don't know the name. It is pretty big though; has about 20,000 people I believe. Well, goodnight precious darling little Mary. "Duck's rest" and God bless you my dear dear wife. Another day has gone by, precious. If I could only see you just for a second sweetheart I would be the happiest person in the world.

Heaps \& heaps \& heaps \& heaps of love \& kisses, From your most loving Austin
Dearest darling little wife,

We have just arrived at Otaru, where we have come for coal, to fill up before going north. This has been the coolest day we have had so far: in fact it was almost cold last night. The summer is really over out here, at least in the northern part of Japan. We dredged all this morning and took one haul this P.M. and then ran for Otaru. I expect we will stay here all tomorrow to coal, leaving tomorrow night. The sea has been glassy all day: the ship had scarsely [sic] any motion. We ran along close inshore all the time. It is very hilly here, being all volcanic country: but you never saw so many houses: every valley coming down to the sea had a village at the end of it: and there are lots and lots of valleys too. Besides these there are lots of scattered single houses. In one place alone we counted 10 separate villages (many of them quite large) all in sight at one time. Otaru is quite a big place, almost as big as Hakodate. I haven't been a shore yet as we have just got in. I thought I would write you right away dearest and post it this evening, or there may be a boat going out. There are 7 large steamers in here. This cool weather here dearest dearest wife, makes me think it may be getting cool at home now. You will be careful precious won't you, and when it gets cool you will wear your thick underthings, won't you dearest? You want to be specially careful dearest dearest wife, because when I get back perhaps we may see our way clear to have a dear little something together Mary (I hope to God we do) and of course we both want to be in perfect health so it can begin from the very start under the most favorable circumstances. Don't you think so dear dear wife? It seems to me darling it is our duty to be extra careful of both ourselves for quite a while before we do anything like that, don't you think so Mary? I am going to be of myself dear. I am in excellent physical condition now, and weigh 148, a gain of 18 pounds since I saw you. I do so hope we can do it Mary: I would just be the happiest person alive. Just think of it; to have a little child with the most perfect woman in all the world. I do so long to see you precious and give you the things I have been getting for you I can scarcely wait. We shall soon be at our "farthest north" and then we shall work down toward Yokohama and home. Keep up your spirits dear little girlie, it won't seem so very long now. I forgot to say dearest, be especially careful of yourself when you are under the weather, won't you precious. Goodnight and "duck's rest" dear dear wife. God bless you Mary: from your most loving husband. P.S. Heaps \& heaps $\&$ heaps $\&$ heaps of love $\&$ kisses. 


\section{Sept. 22, 1906}

Dearest dearest sweetheart,

We left Otaru at 4 P.M today, and are now headed for La Perouse Strait, between Hokkaido and Sakalin. Dr. G., Metters, Burke and I went ashore this P.M. and saw what there was to be seen in the town. It is a large place, about 80,000 people, but entirely Japanese, even more so than Hakodate. There are no interesting features in the town, all the houses and shops being decidedly unpretentious, and the whole place presenting rather a cheap aspect. There are a number of enormous school houses however, and a railroad out from each side of the town; to Sapporo, (the capital of Hokkaido), and to Hakodate and Muroran. Lots of big ships come in here for coal, and take away cargos of railroad ties to the U.S. and China. The country about here is hilly and rather pretty, and the large bay on which the town is situated is fine. Metters went ashore last night and ordered a heavy silk kimono, and is now wondering what he wants it for. It is going to cost 17 yen $(\$ 8.50)$; but he told the doctor he paid $¥ 6.50$ for it. The doctor, when anybody buys anything, invariably has one better for less money than the other person paid for his, and Metters is palming off his kimono as a 6.50 affair to make the doctor envious: he has succeeded well too: the doctor swallowed it all right, and is simply green with jealousy although he doesn't show it much. About every meal Metters says "Don't you think that was a pretty swell thing for 6 yen doctor?" Metters was in a silk store at Yokohama looking at some embroidered chemises: he was just about to buy a dozen when Hazard suggested perhaps underclothes weren't the very best things to give young ladies as presents, so he didn't order any: however he had already bought a silk nightgown (for 55 yen) intending it as a present and now he doesn't exactly [know] what to do with it. He hadn't realized it was a nightgown when he bought it: I don't know what he thought it was. He is already beginning to get tired of the things he bought at Petropaulski and Hakodate, and has given a good many away: he also is tired of seeing his Satsuma teaset that he got in Kagoshima around, besides, he wants the space it occupies for more things he intends to get when we get back to Yokohama. He certainly is the strangest person, a regular true sailor; when he has money he has to spend it, it doesn't make much difference what for. Well dearest dearest wife, we are well on the last stage of our trip at last darling. We are going up to Sakalin and then work down to Yokohama, and then go home. Another day has gone dear wife: cheer up precious, the days are getting fewer and fewer now dear. Good night dear little precious sweetheart and "duck's rest": God bless you Mary.

Sept. 23. I had quite an eventful day today: when I was down to breakfast a huge wave came over the side, swished down the gangway, and splashed down into the wardroom. Unfortunately, I had left my door open, as it wasn't at all what you would call rough, and as the water was about 4 feet deep along the gangway past my door, of course, it all sloshed in, filling my room up even with the top of the threshold (about a foot from the floor), and splashing all around. Just about everything was soaked: when I got there the water was as completely over everything as if my room had been squirted with a hose: water was dripping everywhere from the ceiling and from the shelves, and was knee deep on the floor. Sogie got to work and bailed it out with a bucket, and then mopped it up. When he had fooled around for a while he came and told me everything was all right; but I took the precaution of going and looking for myself. I found things about as they had been half an hour ago, except there was no water on the floor. I took some towels and wiped the ceiling and shelves off, and then looked in my drawers. The lower tier was full of water, and Sogie had taken all the things out of them and put them in on top of the dry things in the upper drawers, so everything was soaking wet. Rather brilliant of him, wasn't it? I was sort of mad about it, do you wonder? Fortunately, I only keep underclothes in the drawers, and my good clothes underneath my bed (which lifts up, disclosing a sort of cupboard underneath). Well, I took all the things out of drawers, and strung lines back and forth across the lower lab. and hung them up to dry. Luckily my desk was closed: but Sogie had found a bunch of wet papers swimming about somewhere, and opened the desk and stuffed them in, so everything was a mess there. Well, I got everything straightened out at last, and discovered that, while at first, it seemed as if all my clothes were ruined, I really didn't lose a cent, as none of my good clothes were at all hurt. Wasn't that lucky? Practically, I think absolutely everything in the way of clothing I had was wet except the new clothes I got at Yokohama, my black suit I just got before we were married darling, my dress suit, and the silks I bought for you dearest. Not a single solitary thing was hurt. I have felt like punching Sogie's head all day; so you can imagine my satisfaction when about 4 P.M. I saw Teed marching him along toward the captain. I knew then something was up. After a while I saw Teed holding him by the scruff of the neck, hustle him forward up under the forecastle head. I found out later that he had lashed his hands [?] up according to peculiar ideas of his own, and refused to do it properly when directed to do so by Teed. He got 2 days in the brig on bread and water for refusing to obey the master-at-arms. I only wish he had got a couple of weeks. We are all hoping he deserts at Yokohama when we get back: he is the most worthless object I have ever seen in a long while. Dr G. told me today he had been thinking about giving me some group of sea animals to work up and write a paper about when I get back dearest and he is going to suggest to the commissioner that I write up the sea lilies. $\mathrm{He}$ is going to suggest that I do it in connection with some of the men in the museum at Harvard. Wouldn't it be great for me to be sent up to Cambridge to work on them for the next winter dearest wife? I think it was mighty good in Dr. 
G. to think of it, don't you, dear? I have been dredging all day at the western end of La Perouse Straight [sic] in the Gulf of Tartary, and have made some pretty good hauls. One day more has passed dearest wife. Tomorrow we are going north along the coast of Sakalin, and the next day around to the other side of the island into the Okhotsk Sea. Good night dearest dearest dearest darling sweetheart.

Sept. 24. It has been an elegant day today; sunny and cool, not at all the kind of weather we expected to get up in these regions. We have been dredging all day off the western coast of Sakalin, in the Gulf of Tartary. We have been fairly close in all day and just a good view of the island. It is hilly but not very high and is covered with small trees. This morning we saw an enormous school of fish off shore all jumping about and raising a great commotion. They seemed to be salmon. We dredged up half a dozen or so large crabs today weighing about 10 lbs. each, and one that weighed $16 \mathrm{lbs}$. and was nearly $5 \mathrm{ft}$ from claw to claw. They were fine eating. It was shallow water all day today, so we had plenty to do putting the things away in time to receive the next haul. It takes about 5 minutes for the dredge to come up or go down every hundred fathoms: so you see when we are working in water only 100 or 200 fathoms deep it doesn't take very long to make a haul; while if the water is 2000 or more fathoms deep it takes a good long morning's or afternoon's work. We are going to work around the southern end of the island tomorrow, and then go up the east coast perhaps calling in at Korsakoff. One day more has gone precious. Good night dearest dearest dearest wife and "duck's rest; God bless you Mary.

\section{Korsakoff, Sakalin Sept. 25, 1906}

\section{Dearest dearest sweetheart,}

We arrived here about 5 this P.M. after having worked about the southern end of the island all day. We had another fine day today, clear and sunny and smooth like yesterday. We rather expected it to be foggy and mean and rough up here, but have found it quite different. I believe the foggy season is over though. We also were rather afraid that it would be cold and snowy, but it has only been pleasantly cool. Korsakoff is a small place of 100 or 150 houses I should say on the shore of a wide and deep bay. It looks decidedly dreary and desolate from the sea. The country about it is hilly, but not high, and is mainly covered with grass and small trees. This part of the island belongs to Japan now: they took all of Sakalin below the latitude of $50^{\circ}$ that is, the southern half, after the war. It formerly belonged to Russia. We are anchored a good way out from the shore. There are three other steamers in here now, so it seems as if there was a little activity in the place. A good many of the houses are new, too. I am going ashore tomor- row morning with Dr. G. to take a look around and see what there is to be seen, and I shall try and get a chance to send this letter off precious. After leaving here darling, our work will take us gradually south, nearer and nearer home dearest, until we get to Yokohama, when we shall leave direct for S.F. Keep your spirits dear little sweetheart, it won't be so very long now before we are together again, never to part any more dear. Won't we be happy though? Won't it be fun setting up housekeeping together dearest? I shall be just the happiest and proudest husband in the whole world Mary. Somehow the more I think of you dearest the more I realize how unworthy I am of such a brave and noble little woman; such a perfectly ideal wife; but I am going to do my best to improve all the time darling, and I am trying all the time now dear, too, so as to be worthy of my dear little prize some day. I can't see why I was so lucky as to get you Mary, the finest and dearest little woman who ever lived but I was, and I am going to try and show you all the rest of my life dearest, how much I appreciate the prize I have got. Good night dear dear dear Mary and "duck's rest". God bless my darling wife.

Heaps \& heaps $\&$ heaps of love \& kisses from your most loving husband

\section{Austin}

Sept. 25. Dearest dearest wife, Went ashore with Tongue at Korsakoff (Sakalin) this morning and mailed some letters to you darling. I was lucky enough to just get them in in time, as the mail steamer left for Hakodate in about an hour. Korsakoff is at the southern end of Sakalin, near the head of that bay in the extreme southern portion. I never saw such a town as this before: practically all of the houses are less than a year old; 1300 were built last year. I only saw perhaps a dozen in all (mostly log houses) which had been there during the Russian occupation. Houses were going up on every hand. One whole street, nearly a mile long, was almost entirely new stores, with the boards not yet weathered. The goods sold were only such indispensible articles as a new community just starting in would need: cheap crockery ware, iron ware, cheap clothing, and eatables. There was one store displaying a lot of picture postals, but none of them were of Sakalin. There were a few "rickshaws, and a number of Russian "droskis" drawn by little shaggy maned ponies. The town is in 2 sections, separated by a hill. There were 5 steamers lying here when we got in. The whole place swarms with Japs: they have certainly taken hold with a vengeance. Every one of them seems busy too. It was a common sight to see 3 or 4 coolies at work on a house together with a man evidently of the better class, and apparently the owner. Everything is energy here: the Japs evidently intend to make the island pay, even if the Russians didn't. Do you remember dearest reading the "Search for a Siberian Klondyke" together last year? You remember this was the place where the author had his "pleasant sensations on being shared by a murderer". This town used to be the place where all the 
worst Russian criminals were sent. Tongue and I only saw one solitary Russian among the thousands of Japs and he was an idiotic sort of being, every single Rusian is gone, either to Vladivostock on the mainland or to Alexieff in the northern part. The Russians still own that part of the island north of lat. $50^{\circ}$. We went ashore at 7:30. It was a rather rough trip, and rather long as were anchored about a mile and a half out. It was a fine day: but at about 10, when the boat came in to take us back, it began to rain and blow. It must have been [taken] about an hour to get back to the boat, as the sea was very rough. It was fortunate the captain had sent in the whaleboat with 6 men, or we would have had a time of it. As it was we all got soaked through. As soon as we got aboard we weighed anchor and stood out to sea. In the P.M. we did some dredging in the larger bay in the southern end of the island, and we are now steaming north, to dredge tomorrow in Patience Bay on the eastern side. One day more has passed dearest wife, and the last stage of this miserable cruise is well started. We are going to work along the east coast and then SE to Iterup in the Kurils, and then S along the Japanese coast to Yokohama, and then straight home. Good night dear dear dear sweetheart and "duck's rest" darling God bless you Mary.

Sept. 26. Have been dredging up along Sakalin coast all day. We managed to lose 3 nets today, the first one with the frame and 216 fathoms of wire rope. We got up a new frame and put it together only to have the net torn off it by the rocks on the bottom. Another net was similarly served up. We haven't been so destructive for a long while. This coast of Sakalin is just about like the other; hilly and rugged, but not very high, and mainly covered with low pines. It seems funny to think that there are tigers here so far north doesn't it? This is just the very last of the fall now, and they are expecting snow and ice every minute. We are going to run all night and dredge in Patience Bay tomorrow. Good night dearest dearest dearest sweetheart and "duck's rest"; God bless you Mary.

Sept. 27. We just learned today that all our work will be finished up and we shall be in Yokohama ready for the fitting up to go home on Oct. 27. I am glad we have some definite information at last. I think it is decidedly mean to say at the beginning of a trip that we will get back in September and then put it off and put it off and put it off the way this has been, don't you? Well dearest we have something definite to go on at last; that is some comfort anyhow. Somehow knowing when is some comfort anyhow. Somehow knowing when the end is going to be makes me lots more impatient and sort of homesick, dearest. I don't see as that helps things any, but dear, I can't help it. I promised, dearest that I wouldn't write any homesick business in my letters, precious didn't I, so I won't any darling, although when I start to write I have hard work to write anything else. We have been dredging all day about Patience's Bay and Robbers Island. Robbers Island is a sandy place, its only claim to importance being the existence of a rookery of fur seals on it, protected (formerly) by a few soldiers. The seals have all left for the winter now. We anchored tonight just inside of Cape Patience. It is one of the most desolate places I ever saw all brown sand with almost no vegetation. Near the anchorage is a big mesa a mile or so along the top, ending in a cliff, terminated by a big natural bridge out over the sea. From the ship we saw hundreds of ducks flying about over the land, but I didn't have any chance to go after them, as we got in about sunset. It is rather rough anchorage, as this is an open bay and there is quite a wind blowing, but it is better than drifting about at sea. Well good night dearest dearest darling Mary and "duck's rest" precious; God bless you dear dear wife.

Sept. 28. Dredging all day again, same as usual. After you get this letter dearest, you had better address your letters "care Postmaster, San Francisco". He will forward the letters to Honolulu until he gets notice from the captain to keep them. We are having the most surprising weather for this part of the world, nice and sunny quite different from the fog and rough seas we expected. It is rather cold, though, about 40 . Of course that is not really very cold, but it seems so after all the warmth we have been in the last couple of months. We are out in the Okhokst Sea now and are working SE toward the Kuriles. We are going to fool around there for a while and then go back into Hakodate. Well, precious another day has gone dearest and there aren't so many of them to go now as there were a while ago. Keep up your spirits darling, it won't be so very long now before we meet again. Good night dear dear dear wife and "duck's rest; God bless you my Mary.

Sept. 29. Dredging again all day. The temperature at the bottom was only $29^{\circ}, 3$ degrees below freezing, but we got lots of fish and things. Salt water doesn't freeze as easily as fresh; it freezes at about 28 , while fresh water freezes at 32: so if you took the fishes we caught and put them in a pan of fresh water, it would freeze the fresh water solid. Seems funny, doesn't it dear, to think of fishes spending all their lives in water so cold that if it was fresh it would be solid ice? Nothing particular happened today; it was just the same as any other day at sea; got up, ate breakfast, watched the dredge go down and come up, ate lunch, watched the dredge descend and ascend again, ate dinner, played a couple of games of chess with Hepburn, and then sat down to write a line to you dearest, after which I am going to bed. Doesn't sound very thrilling, does it darling? Especially after several months of just exactly the same. Still the time is getting less every day, Mary, and it won't seem so very long before I see my darling little sweetheart once more. Cheer up dearest; we won't ever be separated again, will we? Won't we be the most foolishest couple that ever was? Won't it be fun next winter to read to each 
other evenings books on Europe and Japan and explain them to each other? Well good night dearest dearest dearest sweetheart and "duck's rest"; God bless my darling wife.

Sept. 30. Dredging again today, same as usual. The weather is still fine, but chilly. We are pretty well across Okhotsk sea by this time, and I expect we will be near the Kuriles tomorrow. The Paymaster is growing a little tuft of whiskers on his chin, like a goat. It has just reached the stage where it looks as if his chin were mildewed. Metters is growing a beard; it is abut $1 / 4$ inch long, and coal black except for occasional gray hairs, He looks like one of these old pirates you see in pictures. Crater's birthday is coming along pretty soon: he will be 40 years old: he doesn't look as old as that, does he? This much dreaded Sakalin trip is nearly over at last dearest and we are all mighty glad. I don't know why but everybody on board dreaded going up to Sakalin the worst way. It seemed sort of like going on a new cruise, and like leaving home for unknown parts to leave Yokohama, with all its Europeans, to go to that infernal out of the way hole. Yokohama is the only really decent place we have seen and that is decent only because most everything there is European. The captain delivered his ultimatum to Dr. G. last night; that, no matter what happens, he is going to wind up this cruise on the 27th, and be in Yokohama on that date, ready to refit to go home. I believe Dr. G. would dally around here for years if he could. He is so underhanded: he never will tell what he is gong to do: he always answers all questions with "I don't know exactly", Anyhow, I am glad the capt. has taken things into his own hands at last. Well, dearest dearest dearest sweetheart, the days are getting fewer now, and it won't be so very long before we meet again, will it? Take good care of yourself darling. Good night dear dear wife and "duck's rest"; God bless you Mary.

Heaps \& heaps \& heaps of love from your most loving husband

Oct. 1. Dearest dearest sweetheart: dredged all day as usual: we were about the southern end of the Kurils today, just north of the northern end of Hokkaido. We dredged along the southern shore of Kunashir Island. It was a lovely day, sunny and pretty warm, with no wind. On Kunashir we saw some steam coming out of a hole in the side of a mountain near the top. There was some snow on the mountains on this island, too, in ravines near their summits. Nothing particular happened today: the doctor had a nightmare last night and woke everybody up in the wardroom by hollering. It seems nice to see the Japanese shore again after being so out of the world up at Sakhalin: it means, dearest, that the last stage of our journey is half over. We are going to work south along the coast to Yokohama, and then go home. Cheer up, precious it won't be so very long now dear, and try to think of Washington precious. Good night dearest dearest dearest wife and "duck's rest" and pleasant dreams. God bless you dear Mary.
Oct. 2. Twenty five today!! Just think dearest I knew I wouldn't be able to get you a present exactly on your birthday, so I took the precaution of ordering one for you at Yokohama dearest, which will be all done when I get back there. I do hope you will like it darling. I am not going to tell you what it is at all dear, but I will show it to you the very first thing when I see you dearest: It has been rainy and rough all day. Last night we went around Kunashir; going to the north of it, as the channel south of it is shallow and narrow, and hard to get through, and we are now in the midst of a lot of little islands east of the southernmost end of the Kurils, or NE of the northern part of Hokkaido. By the way, Hokkaido is the same as Yezo, which is the way it is given on many maps. Japan is composed of 3 islands (main islands, that is); the northern most is Hokkaido with Sapporo as its capital and Hakodate and Otaru its chief seaports, the middle one is Nipon [Honshu], with its capital Tokio, and its ports Yokohama, Kobe, Nagasaki, Sendai, etc., and the southernmost is Kiushiu [Kyushu] with Kagoshima its capital and chief seaport. Now each of these islands have two names: Hokkaido and Yezo; Nipon and Honshiu [Honshu], etc. Hokkaido written in Japanese of course is pronounced by a Jap, Hokkaido; but if the characters spelling that name in Japanese were read by a Chinaman who didn't know Japanese of course he would pronounce it in the way the same characters would read in his language, which is quite different. Now it happens that the Chinese pronunciation of the Jap. characters is widely used here; so starting with two names for each island, we have 4 entirely different names of each place. Rather confusing, isn't it? We had a little excitement today: a pulley down on the berth deck (where the men live under the forward part of the main deck) on which the dredging rope passes broke, and flew forward into the reeling engine, owing to the net suddenly catching to the bottom, just as it did a while ago at Kagoshima. This suspended operations for the rest of the day. Dr G. was mad, but everybody else bore up under the strain wonderfully. Crater and a couple of his men worked on it this P.M. and got it into shape so we can work tomorrow, but it will have to wait until we get into Hakodate to get it really fixed.

Oct. 3. Rough and rainy today, but not so bad as yesterday. We have been dredging all day as usual. We expect to get into Hakodate tomorrow, where I hope a lot of letters will be waiting for me from my precious little sweetheart. Absolutely nothing happened today. The dredge went down and came up and went down again just the same as ever. We succeeded in ripping up a lot of nets though on rocky bottom; we tore up 4 altogether. We are steaming for Hakodate now, and as we are only about 70 miles off, we expect to be there early in the morning. I am going to close this letter now dearest so as to send it off the very first thing. Good night dearest dearest dearest sweetheart; 
"duck's rest" and the pleasantest dreams dear. God bless my darling precious wife.

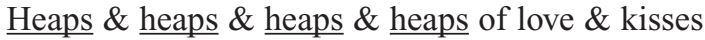
From your most loving Austin

\section{Hakodate}

Oct. 4, 1906

Dearest dearest sweetheart,

The mail this morning was brought on board, and I got a letter from you precious. I was wondering why I got only one after not having any for such a long time, when another mail which had just arrived was brought off and I got six more darling: just think! six letters all at once from the dear little woman who is just all the world to me. The letters were from Capri, Athens, Naples, 3 written on board the "Moltke" and posted in N.Y., and two from Newtonville. I am mighty glad you are safe home at last dear Mary: I couldn't help having uneasy spells dear, while you were in Europe, for fear something might happen and I would be so far away. I think it was great you had the chance to go dearest and you saw such a lot of places too. Won't we have fun reading to each other about them dearest and won't it be just great having you explain all about them to me? I am awfully sorry I bothered you about Lawrence dearest, but you see I am so sort of forlorn way out here and homesick things don't look at all the same as if I were with you, dear love. I am mighty glad you told me all about it darling, but I am sorry I was so silly. You will have to tell me all about Greece when we meet again dear. I have never been there nor to any part of Italy south of Naples. My! But my dear little wife has become quite a traveler, hasn't she? It is a pity it was cloudy so you didn't see the Azores: they are just lovely, especially Pico, the great high one. Isn't an awful shame we aren't going to get back until along the first of December precious? I don't think I ever felt worse in my life than I did when I learned that precious. We are going to get into Yokohama the 27th, and then fix up the ship and lay in supplies and come right home. It takes this boat about six weeks to make the trip across from Yokohama to S.F. Well, precious, I suppose we must bear it somehow: thank God you are at home among friends and not way out in S.F. When we meet again we will never be separated any more darling. I would rather dig in the streets and live with you than get a million a year this way. Anyway, when I get back we will go to Washington dearest, and I shall take mighty good care not to get Shanghaied again. Cheer up precious wife, for it is Washington when I get back, anyhow dear: try to bear it bravely dear little sweetheart, and remember it is the last time we shall ever be separated dear dear Mary. I do get so blue sometimes darling way out here, same thing day after day after day: it seems as if the time would never go and $\mathrm{O}$ God! I want to see you so much it seems as if I couldn't wait. Dear Mary somehow I never really realized how much I love you dear and how much you mean to me before. My motto is now even more than before, "Do what dear Mary would like to have you do, and do it as your darling wife would like to have you do it" dearest, you seem to guide every action just as much as if you were with me all the time. My one ambition dear is to become worthy of the prize which I have got, so when we are both old, Mary, you can say to me, "You have done well, Austin." I am trying to do my best dear, and trying to do better and better all the time darling: but I fully realize that I can never be really [damaged - illegible] of you Mary, the finest and noblest little woman that ever lived: I can only try my best, precious, and I am trying and trying all the time. Dearest, I know no man ever loved his wife half as much as I love you Mary, because no man ever had such a dear and noble wife to love. When we were engaged darling I used to love everything in any way connected with you dear, even the ground you walked on; but dear, I worship them now, and rerun them more and more all the time. You are religion with me dear; do you think I am silly? All the love and reverence most people give to some God or other I give to you, my Mary, in addition to my love for you as my wife. Don't think this is sacrilegious, sweetheart, for it is true dear Mary, every word, and I am going to devote my whole life to proving it to you dear. Do you remember the pictures you drew one night in our room on the Albatross when I was out in the wardroom playing cards with Mr. Hepburn and the rest? I took them out last night (they are on a sheet of little paper you know), but dearest they made me feel so bad I had to put them up again. It was so mean of me dearest wasn't it? Just as if I should have cared if the others thought me queer or not. Anyhow you won't even get another chance to draw any pictures, dear. We will spend just every evening all our lives together dearest, won't we, reading or talking to each other or playing cribbage or chess. I would so much rather have played crib. with you that evening precious, only I was a fool and weakly allowed myself to think of what other people might think. I had a dream last night darling. I think it was the sweetest dreams I ever had. I dreamed I came into a room and there were you in bed holding up to me the dearest and cunningest little baby I ever saw, and you had just the loveliest smile on your face dear. I took it and gave it a kiss, awfully carefully and then put it down and knelt down side of the bed and took you in my arms and kissed you over and over and over again. I was so happy and then I woke up and my eyes were all wet and I was feeling weepy. It was the dearest and sweetest dream I ever had Mary: you did look so sweet and dear holding up the dear little thing to me. I have been thinking about that dream all day dear. Won't it be just heavenly when it can come true? I hope you won't think me too foolish dear, but I do so want a little something dear that the dream made a big impression on me. I am mighty glad precious that Aunt Mary is still in Calf. I should feel rather uneasy about your coming out 
there otherwise, as the Grays are probably not settled yet. We hear out here that S.F. is still in a bad mess, dear so I think it would be best not to get there until the last minute, so as to have as little time there as possible, don't you? I shall cable from Honolulu when we get there dear, so you will know when to start. If you are visiting anywhere you can arrange to have your mother get the message and telegraph it to you dearest. Take good care of yourself precious wife. I was awfully glad to hear you were taking good care of yourself when you were under the weather. You will see dearest it certainly pays in the end. I am taking good care of myself precious. No harm can come to me on the boat dearest: there are no floating mines on this side of the islands, and we have finished all our work in the Japan sea. When we were there we had lookouts all the time and didn't do any sailing at night. The typhoon at Hong Kong last week didn't cause so much as a ruffle up here dear; we shall be always in easy reach of harbors until the typhoon season is all over. Don't be at all uneasy dearest: this captain is the most cautious man you ever saw, and both he and Hepburn know their business thoroughly. Good night dearest dearest dearest sweetheart; "duck's rest" and the pleasantest dreams dear. God bless my darling precious wife. Good night darling precious wife. One more day has passed. "Duck's rest" and the pleasant dreams. God bless you dear Mary.

From your most loving husband

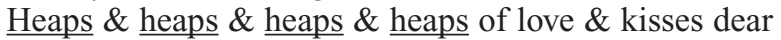

\section{Hakodate \\ Oct 5, 1906}

Dearest dearest sweetheart,

We are still lying here in Hakodate. It was a perfect day today, Bright and sunny, with no wind, and cool and crisp. Yesterday it was squally with occasionally rain, and windy. I went ashore to get some boxes out of the custom house we had stored there when we were here before and brought them off in a "sampan" with a Jap. crew. When I got aboard we had quite a time getting them on board and down into the lower lab., as they were very heavy, and all the men not on shore were drunk. However, the carpenter (a most obliging individual, who I told you a while ago had been promoted to blacksmith, so as to give him more pay), the "bosun" Riley, old Jacobson, and the lamp trimmer, a boy about 17 named Willie Stowe, got to work, and bustled them down in hot order. Old "Jake" was so full he could barely stand, but he can work exactly as well in that condition as when sober. My petty officer Hanson was so full he was absolutely useless, and the other man Hurliby, was on shore filling up. When the boxes were about half of them stored, there arose a great commotion forward. One of the men, a worthless character named McConnell, had marched up to Hazard, and addressing him as "Hazard, old sport", gone on in sort of a rambling way; so Hazard called Teed, the master-at-arms, and told him to lock him up. Teed got hold of him, and then there was a grand scrap. McConnell bit Teed in the leg, and Teed started in and choked him till he was blue in the face. Several of the men sailed in, and soon overpowered the miscreant who was hollering curses at the top of his voice all the time. They put hand and leg irons on him and locked him up; they didn't do it any too gently, either. He will be lucky to get off with a couple of years, as biting is a serious offense. One man tried it got all his teeth kicked out by the master-at-arms, and 5 years in jail, in which to repent. This chap McConnell was drunk: that is what started it. That is the worst of sailors: they are all right at sea; we have perhaps the best crew which has ever been on the ship; but as soon as they are allowed on shore they proceed to get drunk and then raise a row, same as all sailors. They are usually full continuously in port, and it takes about two days at sea for them to sober off. Must be a miserable sort of life I should think. That is one reason they go to sea; they are absolutely useless on land. The old carpenter is a great chap; one of the best carpenters in the navy. He has been on this boat for years. He has a great sense of humor, too. When the boat was at Laysan Island (n. of Honolulu) once about 4 or 5 years ago, a party started ashore in the dory; Dr. G. (who was on board then), old "Jake", one of the F.C. people, and the carpenter; the dory overturned in the surf about a mile from the ship, and about the same distance from the shore. They all clung to the bottom of the craft, as not one of them could swim to amount to anything, and watched the sharks' fins circling about, waiting for a boat to be sent out to them. Pretty soon some albatrosses discovered them, and came hovering around, and one lit with a great splash right beside of the carpenter. He turned and looked at it and said, "Well, can't you wait till I croak?" They had lots of strenuous times that trip, landing through the surf and so forth. I am glad dear that all our landings have been peaceful and tame this trip: always in a harbor or a sheltered place, and we are not going to any risky places dearest. The pay of these sailors when they start in does not seem very high, does it? \$16 a month, until they qualify for seaman, then $\$ 24$. The "chief petty officers" get $\$ 70$. In the British navy a seaman gets $£ 1$ per month (and has to buy his own clothes), and a chief petty officer $£ 4$; and they don’t have any trouble getting men either. That is why no British ships visit American ports; the men all run away and enlist in the U.S. Navy. The last ship lost so many men inside of a week she had barely enough left to get home with. Several of our men were once in the English navy. I don't know why I am writing you all this precious, it surely can't interest you, but news is scarce out here. The ss "Mongolia" which took Dr. Torrey to S.F. ran ashore at Midway Island, being 40 miles out of her course, and was there a week or more, her passengers being transferred to the U.S. Army transport "Buford". That makes both the Pacific Mail Co's steamers out of business temporarily, as the "Manchuria" ran aground at Honolulu a 
few weeks ago. That is one great advantage darling in being in a boat with naval officers instead of ordinary merchant skippers. A merchant capt. gets suspended for a few months for running a boat aground; but a naval man loses his job, and ruins his whole career: therefore he is careful not to do it. Besides he is far better educated, and much better instructed in his profession, and gets about 3 times as much pay. The officers we have are especially good, dearest, so you needn't feel at all worried about me. Besides the 3 "watch" officers are ex-captains themselves, although they are only "bosuns" in the navy. That is as high as a merchant captain can even get: he can never become a real officer like Hepburn and Capt. Garrett. We have just heard of a bad typhoon down at Hong Kong dearest; but you mustn't be at all anxious, as Hong Kong is a long way off, and we didn't feel a trace of it here. The typhoon season will be all over when we start home. I am sending you 4 picture postals with this, dearest, which I got at Otaru. I never saw any like them before. They are little oil paintings and I thought they were rather pretty. I am sending them in an envelope, as I am afraid they will disappear in ordinary mail. They cost 5 cents at home. I am also sending some photographs. They aren't very interesting. One of the men on board took them and gave them to me. One of them is a group of Koreans taken on board at Matsushima Island (Fig. 32). Well dearest dearest darling sweetheart, one more day has gone, and the 27 th is one day nearer dear. Keep up your spirits precious, and think of Washington. Take good care of yourself darling. Good night and "duck's rest" dear. God bless you dearest Mary.

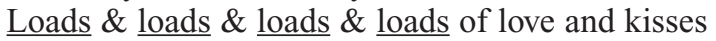
From your most loving Austin

P.S. I see I have turned over two sheets instead of one in writing this dearest: this accounts for these two [damaged illegible]. God bless you again dear sweetheart.

AHC.

\section{Hakodate, Japan}

Oct. 6, 1906

Dearest darling sweetheart,

It has been a mighty disagreeable day today, squally and raining all day, so I didn't go ashore. Nothing particular happened, we just loafed around all day: nobody went ashore because it was so unpleasant. We are going to start Monday morning on our trip to Yokohama. Somehow dearest it seems as if Monday never would come. We shall be in Y. on the 27th, with all the work done, ready to fit up and go home. Dearest wife, if you only knew how anxious I am to get back. It does seem ages since I saw your pretty face precious, doesn't it? Dr. G. flabbergasted me today by telling me we would work all the way to Honolulu; the men were simply ripping about it; but the capt. squelched all such dreams by declaring that everything was to be finished by the $27 \mathrm{th}$, and that no work of any kind would be done after this date: moreover, we are going to run direct to Honolulu and are not going to touch at Wake or Midway Islands, where Dr. G. wanted to spend a couple of days or so: I am glad the capt. has got his nerve up at last. So, precious, we are all waiting anxiously for the 27 th. Cheer up dearest, remember it is Washington next winter anyhow dear and we will never be separated again, even if I have to dig in the streets, will we dearest? Good night precious little darling and "duck's rest" and pleasant dreams. God bless my dear dear Mary.

Oct. 7. Sunday today; we are going to start early tomorrow morning, thank the Lord. We have seen quite enough of this dismal hole. Tongue and I went ashore for dinner this evening at the Hakodate Hotel, the only place of any pretensions in the place. The meal was pretty fair, a great relief after ship feed, anyhow. To our great relief and joy, Sogie, the Jap with the moustache, ran away today, and made good his escape. He took with him some pajamas and underclothes of mine, and some of the ship's blankets. However, we consider ourselves fortunate in getting off so easily. Being rid of him is worth considerable. Another Jap, who belongs to the steerage mess also skipped, but no tears were shed over him either. It rained all the morning, but has been pretty this P.M. There was a big fire here this evening, down by the railway station. Seems as if every place we visit was bound to burn up doesn't it? The last time we were here (or the first time rather) there was a big fire. These Jap houses are flimsy things, and are always of wood, so they burn like tinder. They are very light and all open, so when they catch they are gone before any help can be sent. Metters got a shave today, and they did a pretty complete job on him, even shaving the down off of his ears. He is wondering how he would look in case he should start a beard all over each ear. Crater got a shave at the same time. They used a razor shaped like a carving knife, without any soap. The barber would start in to scrape him and Crater would screw up his face and holler "Oh! I say, old man, that hurts!" every time the barber attempted to do anything. It was simply killing. Of course the barber didn't understand a word of English. Well good night precious and "duck's rest" God bless you dear dear Mary.

With heaps \& heaps \& heaps of love \& kisses From your most loving husband

Oct. 8: Dearest dearest wife: we left Hakodate at 9 this A.M. and have been running S. along the coast all day. It was fine when we started out, but it is just pouring cats and dogs now and is about the blackest night I ever saw. When we left they were practicing at targets from the forts on the hills around Hakodate. The targets were strips of cloth stretched between bamboo poles set up on a raft, and were towed by a small tug. The shooting was pretty bad; 
which however, was probably due to our presence. The main excitement on board now is cribbage, in which Crater is the champion. Chess is getting monotonous, especially as we always know who is going to win if any two of us start playing. Dr. G. is laid up with a cold tonight, so we aren't going to take our usual haul with the tow net: lucky, as it isn't much fun in such a rain. Metters turned in this P.M. about 3, as he has the night watch tonight, and experienced the most blood-curdling series of nightmares in his experience. He dreamed he was lying in his bunk, and a most horrible dragon appeared in the doorway, and gave one leap onto him, pinning down his arms and legs and paralyzing his voice so that he couldn't call for help. Then the ship rolled completely over, and he found himself standing glued fast to the bridge, with Crater alongside of him and the ship rolling over and the water about to engulf him. He implored Crater to unscrew his feet from the deck, and Crater only smiled and waved his hand at him and dove overboard. After that he gave up trying to sleep, and came out into the ward room. We had roast wild duck for dinner today: they cost 35 sen (171/2 cents) a dozen here: nice big fat ones too. Well dearest, thank God another day has passed: 19 more days and we shall be in Yokohama ready to go home. Keep up your spirits darling little sweetheart. Good night and "duck's rest" precious. God bless my darling Mary.

Oct. 9. Nice and pleasant all day today, but rather windy. We didn't do anything today but run, and we are anchored tonight off a little small town, of which I haven't learned the name yet. It is up in a deep gulf which makes in from the sea, and has a fine harbor. We haven't done much all day but play cribbage. I just went down and found that the place where we are is in the gulf of Sendai, right near Matsushima, about halfway between Hakodate and Yokohama. They have a new form of amusement in the ward room: they have one of the Montgomery Ward's catalogues of goods (they are a big department store in Chicago) which they call the "Pleasure Book", and they sit and read about the various goods displayed by the hour. They call it "going through the bazaar", and claim that it is better than a real bazaar, because you see all the things, and yet can't spend any money. The doctor has been "going through the bazaar" all day and Hazard and the paymaster have been waiting for him to get through. Well good night precious little sweetheart and "duck's rest" and pleasant dreams dearest. God bless my dear dear wife.

Heaps \& heaps \& heaps of love \& kisses from your most loving husband

Oct. 10. We started out from our anchorage early this morning and have been working all day. It was fine weather, with a little swell from yesterday's wind. Nothing exciting happened: we caught the usual run of things, and didn't break anything or lose any gear. We learned at
Hakodate that this has been a particularly warm summer up in Kamchatka, and the mountains there have been entirely bare of snow for the first time in the history of the country. The sailors bought a new graphophone in Yokohama when we were there, and got into trouble with it today. They have a song entitled "Roast Beef of Old England". Today some one suggested that it be played, and the hospital steward, who was standing near said "Be sure it isn't canned." The paymaster, who was standing near, was mad, as he thought it was a reflection on the quality of the canned meat he was feeding the men, and reported him for it. The paymaster thought that their having the song was an offense, anyhow, and kicked up quite a row over it, so the capt. advised them to drop the offending record overboard. Do you remember Bogosloff, the volcano we saw in the Bering Sea? Well, when Dr. Heath was here, we were (that is, Mr. Hepburn and Hazard) stuffing him about having seen it rise out of the sea and when he got back to Frisco he put an account of it in the papers, mentioning how it rose up from the sea. Mrs. H. just sent on some newspaper clippings containing the account: we never thought he took it seriously. Well goodnight and "duck's rest" dear precious little wife. God bless my darling Mary.

Oct. 11. I am writing the diary for the 11th on the morning of the 12th. It was so rough last night that it was impossible to sit in a chair, much less manage to preserve your balance well enough to write, it was too rough yesterday morning to do any dredging so we just ran southward toward the southern end of Japan, as we are going to work in Suruga and Sagami bays, just west of Tokyo bay. The wind and the sea rose more and more during the day, till at noon it was blowing a gale and the sea was very high. Fortunately, the wind was from the north and we were going south, so it helped us along. We got everything secured in good shape, and just lay back to watch events. They put wooden covers on all the windows so the sea couldn't smash them, and tied a big canvas over the ward room skylight. The sea got higher and higher till about 4 , when it abated some, and by 11 the wind went down enough so we could turn in without fear of being thrown out of bed. Quite a lot of our crockery ware was broken in the ward room, but no other damage was done, and strangely, no one was seasick. Sleeping in a hammock slung under the ceiling. Such a thing as keeping in bed is, of course out of the question. You ought to have seen the wardroom: they covered up the skylights with a big tarpaulin, but when a wave came it just sloshed up under the edges, lifted the skylights, and came right in. The wardroom was anywhere from $2 \mathrm{ft}$. deep with water down to just enough to slosh around and make it slippery. The water got into the electric light wire conduits, and dripped down from them everywhere. Tongue's office got full, and the water leaked down into Hazard's and Prine's rooms. Crater's room is a soggy mess thanks to a leak in the deck. Luckily, dearest, my room is tight and dry, only a little 
water coming under the door when the gangways are full, which is easily mopped out. It never gets more than an inch or so high. The Jap boys have been waiting on table barefoot and splashing about in the water as they moved. Often they would slip and slide clean across the room. The one named Tommy (he was here when you were dear) has acquired remarkable dexterity. Yesterday he was passing two dishes of vegetables, when he slipped and slid on his back half the length of the room, keeping both dishes right side up all the time. Day before yesterday we were especially unlucky. A big man broke into the galley and swiped all our grub off the stove. The steward opened some sardines; but [end of page].

Oct 12. This morning we awoke in Suruga Bay. It was as bright and clear as could be, and quiet as the proverbial mill-pond; absolutely the reverse of what it was when we turned in. The great volcano, Fujiyama, the sacred mountain of Japan, showed up clear and brilliant (we were almost at the base of it), the upper half covered with snow. It is certainly a splendid sight, all the more impressive because it is the only snow mountain in Japan, and there are no other mountains near to detract from its beauty. We passed Vries about 2 last night, and Metters, who was on watch, says it was lighting up the sky pretty well. It is a fairly active volcano. We have been dredging all day and are now anchored in the little harbor where the town of Shimudzu is located. We dredged in Suruga Bay all day, and brought up tons of mud every haul, except the last, where the net tore and spilled it out. Sindo and Snyder showed up tonight. They arrived at Shimudzu today to wait for us. They were pretty short on cash, Snyder having 35 sen (171/2 cents) and Sindo 80 sen (40 cents) when they came on board. They have just been down to Onigawa [Okinawa], in the Liu Kiu Islands [Ryukyu Islands], halfway to Formosa. Sindo is disgusted with Japan. He says he hasn't had a decent meal on shore since he has been here, and he is tickled to death to get back. He had 100 yen $(\$ 50)$ dollars stolen from him when he was at Onigawa, which was the reason they ran short of cash. Well, precious, goodnight: thank God another day has gone. "Duck's rest" and pleasant dreams dearest. God bless you dear dear dear wife.

Oct. 13. Dredged all day as usual, and brought up lots of mud. We had no accidents, except in the last haul the net was torn all to bits. It was fine and clear today, I got up at 5:30 to look at the great mountain Fujiyama: it was fine: there wasn't a cloud in sight, and it showed up just as pretty as could be. It slopes right down to the sea from here, so you can get the most beautiful and uninterrupted view of it. I got up at 6 and took another look at it. The sun was just rising and it looked just splendid. Along in the morning clouds began to gather about half way up it, and in the P.M. you could only see the base, and the snowy summit towering above the clouds. We are back in
Shimidzu tonight, the same place where we anchored last night. The sea has been as calm as could be all day. When we got in here tonight there was a large steamer lying at anchor, loading tea (this is the chief tea district of Japan), flying the U.S. flag at the fore-mast head, and the Jap. flag at the stern. She proved to be the Tosa Maru, bound for Seattle: she is just leaving the harbor now (9.30 P.M.) bound for Yokohama for passengers and mails. Prine just told me he tried to get a nap this P.M., but the propellers kept saying over and over again "fourteen days more, fourteen days more, fourteen days more" and he was so mad being taunted with the fact that we still had 14 more days to do before we reached Yokohama, he had come up on deck. It does seem just ages since I saw dearest dearest wife, doesn't it? I try to bear up and think it will be all the more pleasure to see you, now that we have had to wait so much longer than we expected, but dear, it doesn't seem to work: I just couldn't possibly want to see you, precious more than I do now: I would give just anything to be able to take you in my arms and kiss you dearest. Well, precious little darling wife, tomorrow it will be 1 week and 6 days dear. Keep up your spirits dearest dearest dearest wife. Good night and "duck's rest" dear sweetheart: God bless my darling Mary.

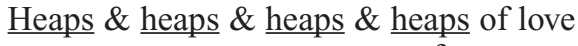
from your most loving husband Austin

\section{Shimudzu, Japan Oct. 141906}

Dearest dearest sweetheart,

We all had quite a picnic ashore today. Dr. G., the surgeon, Sindo, Snyder, Prine, Burke, and I all went out to a very famous temple where the first "Shogun" of Japan is buried. The Shogun used to be the military ruler of Japan, as the Mikado was the civil ruler, but was in reality, the more powerful of the two, as he had the whole army back of him. This temple is about 2 miles out in the country from Shimidzu. It is a very pretty ride (in 'rickshaws, of course) through fields of rice and sugar cane. It was a gorgeous day, bright and warm: Old Fujiyama was fine: not a cloud about it. The temple is called the "Thousand Steps", because it is on the top of a high hill, and there are 1000 steps up to it. I am sending with this a sort of panoramic picture of it dear, which gives a pretty good idea of it. We left the 'rickshaws at the little houses down on the lower margin, and then started the climb. At intervals all the way up are smaller temples or places where you get a fine view, so it does not seem nearly so far as it really is. The big temple near the top of the picture (which I have mailed with an arrow in the margin) is simply gorgeous. I have sent you a postal with a nearer view of it. It is built of lacquered wood work, with all sorts of carvings and paintings. You can see a row of carved 
wooden panels in the postal, just above the stone-work. We took our shoes off (every single one of us had holes in his stockings) and went inside. The inside was all lacquered wood-work, with panels painted by emperors and famous people set in the walls. We each put in a few coppers into a sort of contribution box, and this priest gave us each a little cup of consecrated "sake" or rice wine, and then gave us the cups. They are of unglazed earthenware, each with the crest of the Shogun in the bottom. That tree on another postal dearest is supposed to be 1000 years old: it is an old distorted pine, with an enormous gnarled base and some branches (extending out toward the right and not shown in the picture) low down near the ground. On these branches everywhere where a person could reach were tied little wisps of Japanese paper. Young people who want to get married go and tie a piece of paper to one of the twigs (it must be tied only with the thumb and little finger of each hand); and if there is anybody who wants to marry them, then they go and tie another knot in the same bit of paper. We had a great time getting 'rickshaws here. We wanted 7, which proved to be all the town possessed, and it took about half an hour getting them together. Tongue went to the railway station (in another town a couple of miles away), as he is going down to Yokohama for mail, and coming back tomorrow. I do so hope I get some letters precious. We got back too late to get dinner on board, so Prine and Sindo and I all went to a Japanese hotel and got a Jap meal. We had soup with shrimps, mushrooms, and various vegetables in it, beefsteak, raw fish, and cooked fish. Of course we had to sit down on the floor and eat with chopsticks. There were no chairs or tables in the place. After dinner we went to another town, Izili, about 2 miles away, a place famous for it laquerware. We visited some stores and I got you a couple of the prettiest lacquered boxes dearest. They are very cheap here, as no tourists ever come here. We visited a second-hand store and I got a weird looking teakettle of cast iron, of a make they call "Nambu ware", which differs from other iron in that it won't rust. This kettle is the product of a famous maker of such things, and bears his autograph. It is a very old one, and has been in steady use the last 20 years. I also got a couple of very old Japanese prints, like those we saw at Washington dearest. They are well done and will be mighty pretty framed. Real old Jap. prints are very valuable: if you buy them at Tokyo or Yokohama you pay fabulous prices for them, but out here where the tourists never come they are very cheap. I forgot to say dearest I got a Jap. pound (1 1/3 lbs.) of the very best tea grown in this region. It costs 55 sen $\left(27 \frac{1}{2}\right.$ cents). It is this year's crop, so it is perfectly fresh. Ordinary tea sells here for 4 or 5 cents a pound. We will use it precious when we give teas to people next winter. We got back from Izili to Shimudzu at about 11.30, and got on board at 12, so I am rather sleepy, as I haven't turned in later than 9 for months. Well goodnight precious little darling wifey, and “duck's rest" dearest. It seems funny writ- ing goodnight dearest, when it is about noon where you are, doesn't it? Pleasant dearest dearest dearest sweetheart: God bless my darling wife.

Oct. 15. Dredging as usual all day. We used one kind of net, and then the capt. wanted to try another larger kind. This got torn all up, so we had to use another kind. Then the frame struck a rock, and got bent up all out of shape, so we had to use still another. Just before noon the dredge came up bringing with it 3 Jap. fishing lines which had got tangled up with it. They use very long (half a mile or so) lines, with little lines with hooks every 6 feet, just as the fishermen (at) home do on the Grand Banks of Newfoundland. It was a fine day again today, just as clear as it could be without a cloud. There isn't as much snow as there was on Fujiyama, it seems to be melting off some. It was quite warm today, so that the captain appeared in shirt sleeves and a white helmet. I am writing this just before supper dearest, as we are steaming into Shimudzu, as perhaps I shall have a chance to send it of when we get there tonight. I am so anxious to see Tongue and get the letters dearest. I can hardly wait. He will be at Shimudzu when we get there. Twelve days more of this miserable trip dearest, and we will be in Yokohama, ready to refit and say goodbye to Japan. One more day is nearly over precious. Keep up your spirits dear little sweetheart and think how happy we shall be when we see each other again. Won't it be just heavenly precious? Just think of our living in Washington. Au revoir dearest dearest dearest sweetheart and God bless you Mary.

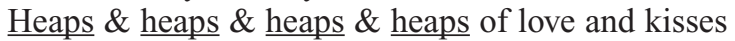
from your most loving husband Austin

\section{Shimudzu, Japan \\ Oct 15, 1906}

Dearest dearest sweetheart,

When we got back home tonight we found Tongue, with the mail from Yokohama, and I got three dear letters from you darling wife. One was from Athens, one from Tamworth, N.H., and the other (Sept. 24) from Newtonville. I was so glad to get them precious. Won't it be fun reading over our letters to each other and explaining them dearest? We have probably written lots of things that will easily slip our minds (I know I have); and when we read them over we will recall lots of other things too. I am curious to know what you think of the photo of me with a beard, dearest. I will wear it till I see you dear, and then if you don't like it, will amputate it immediately. I will look up some centerpieces when we get back to Yokohama dear and get some for future use. I will also look up some silk for you dearest, and for Betty. I think I can get some pretty cheap, and I don't expect there will be any trouble getting it through the customs. So Kate is going to be married at last. I am 
glad for them: it must have been a horrible wait, mustn't it dear? I don't know if I told you, but when we were up in Hakodate last, I got 3 red fox skins for Ros for a set of furs. Ma is going to pay what they cost when I get back. We have been dredging all day out in Suruga bay, bringing up tons of mud at each haul. Once when we were undoing a net chock full of mud it all came out with a rush, and a big gob of it about as big as an orange bounced from the rail and hit the "'bosun" square in the eye before he had a chance to duck. Another time one of the sailors was looking on with his mouth open and big piece flew right in. We succeeded in ripping up several nets, to the great disgust of Hanson. We expect to go around into Sagami Bay tomorrow dear, and to spend the rest of the time there. Well, dearest, goodnight and "duck's rest" and the pleasantest dreams darling little wife. God bless you my Mary.

Oct. 16. Dredging again all day. We brought up piles of mud as usual, and not very much of anything else. In the last haul all we got was a crab and a little octopus. It has been warm all day like yesterday, but not sunny: we couldn't see Fuji all day, although we could see it all yesterday. We didn't expect to come back here tonight but the barometer was falling, and this is the best harbor anywhere around, so we finished up early and came back here. We are going to be in Yokohama on the 27th dearest (a week from Saturday) ready to fit up to go home. We shall probably start about Nov. 7, dear. The trip takes 6 weeks for the ship. I will cable from Honolulu when we leave there darling. Somehow dear these last days do drag terribly they do seem just ages long dear. Eleven days more. It doesn't seem long when you think of it off hand, but when you spend every minute dear in impatiently looking forward to when they will be over darling they seem as many weeks. I do so long to see you dearest dearest wife. We won't ever be separated again, will we dear? We will just keep together just as long as we live, won't we dearest. I seem to love you more and more and more all the time precious dear, it sort of seems as if I had never really appreciated your full value before. The more I think of it the more I wonder how such a wonderful little woman as you could even like me. Well dearest good night. Another day has gone dear. "Duck's rest" and pleasant dreams darling. God bless my dear dear wife.

Heaps $\&$ heaps $\&$ heaps of love $\&$ millions of kisses From your most loving husband

Oct 17. We have spent the day looking for a place to dredge. We started out from Shimadzu at 6, and ran S. 35 miles, and took a sounding, but didn't bring up any mud or sand, so judged it was rocky, and sailed about 5 miles and tried again, with the same result. The next time, however, we found what we thought was more promising bottom, and lowered the dredge. Just as soon as it reached the bottom it caught and was held fast by rocks, so we hauled up what was left of the dredge wire, and started for another place. We didn't find any suitable, however, so did nothing the rest of the day. We are going to steam slowly, under reduced speed until morning. It has been warm and muggy and overcast all day, and is raining now. One week and 2 days more, and we shall be in Yokohama. Somehow the days drag more and more as time goes on dearest, I am so impatient for it to be all over. Won't I be glad when we reach Yokohama again? The first thing I will do precious will be to get your birthday present dear which I am having made there. I wonder what you will say when you see it. I am going to get you a "Nov. 12" present too darling. What do you suppose it will be? I'll bet you can't guess, for I haven't decided myself yet. We shall get home dearest about Dec. 15: we hear from the papers that conditions are very bad in Frisco dearest, so perhaps it would be best for you to plan to get there not earlier than Dec. 13 anyway, as I shouldn't like to think of you staying any length of time there dearest with things the way they are there now. We hear dearest they are going to get the soldiers back to preserve order. Ma writes that Aunt Mary is going to stay in Berkeley till Spring anyway, which relieves my mind very much. You can go and stay with them dearest. You will take the greatest care of yourself precious little wife, won't you dearest, and not attempt to go running about alone please dearest. Just stay with them and wait till I come precious, won't you? I should feel so anxious if I thought you were wandering about there alone dearest. And you will take the greatest care of yourself in coming out in the train, won't you dearest? Don't think I am too old womanish, dearest, but you mean so much to me precious little sweetheart. Well, goodnight dearest dearest dearest wife and "duck's rest" and pleasant dreams. God bless you, Mary.

Oct. 18. Dearest dearest sweetheart: last night about 4 o'clock it began to blow up some, so the captain headed for Shimudzu, and started toward there full speed. We got in about 10:30 this morning and have laid here all day. It was rainy early this morning, but as soon as we got in here it cleared off and came out fine and sunny. Fujiyama has lost its snow cap now, only a few traces remaining, through the warm weather we have been having. I went ashore with Tongue this P.M. and we walked around a bit to stretch our legs. It was pretty warm on shore. One week and one day now precious; it does seem as if they would never go. Well precious little wife goodnight. "Duck's rest and pleasant dreams dearest. God bless my perfect little wife and make me worthy of her some day.

Heaps $\&$ heaps $\&$ heaps $\underline{\text { h heaps }}$ of love \& kisses From your most loving Austin

Oct. 19. We got away early this morning, and have been dredging all day, in water about 500 fathoms [3000 ft.] deep. Absolutely nothing has happened: we took two hauls in the morning and 2 this afternoon and got the 
usual number of queer things, starfishes etc. I forgot to say that a couple of days ago Dr. Mitsukuri, chief of the dept. of zoology at the Imperial University of Tokyo joined us, to stay with us to the end of the trip. He has been seasick most of the time so far. Seven days more precious. Time does drag so toward the end dearest: this last week has seemed a month. You will take awfully good care of yourself when you come out to California, won't you dearest Mary? Just stay about the house dear, and be awfully careful. It says here in the papers it isn't safe for a woman to walk the streets of San Francisco even in broad daylight. Do be careful precious, won't you dear? Remember all you are to me darling Mary and how I should worry if I thought you weren't taking the best of care of yourself but then dearest, I know you will, so I won't worry. Good night dearest dearest dearest wife and duck's rest. God bless you dear dear Mary.

Oct. 20. We spent all last night running slowly and ran on a new fishing ground this morning. We dredged all day as usual, and got various kinds of queer things, among others a small blind pink fish, from about 3,000 ft. below the surface. We were in deep water today, so we only took 4 hauls, and then started for Sagami Bay. (We have been dredging just south of it). There has been great speculation all day as to whether we would anchor on Sunday (tomorrow), or whether we would work, but we are now running to Atami to spend Sunday, to everybody's great satisfaction. This has been an awfully long day somehow dearest these days do drag awfully toward the end. Cheer up precious it will soon be over now. Good night dearest dearest dearest wife and "duck's rest" and pleasant dreams. God bless my dear dear Mary

Oct. 21. Land at Atami, in Sagami Bay all day. There was quite a breeze blowing all day and this anchorage is hardly protected at all, so nobody went ashore. There are no wharves here, so you have to land on the beach, which is all large pebbles and very steep. The country here is mighty pretty from the ship. There is a little town right on the beach, with two broad flat valleys extending inland from it, all planted in rice. The rice is all yellow now, as it is nearly ripe. Except for these valleys the whole country is hilly, with pretty high hills too, all cultivated in terraces, each terrace with a crop a different shade from that of the nearby terraces- various shades of green, brown or yellow- and interspersed with hedges and solitary trees. It rained most of the day today. Everybody is rejoicing in the thought that this is our last work. Well, goodnight precious little darling and "duck's rest". God bless you dearest dearest Mary.

Oct. 22. We started out early this morning, but it was so rough that we came right back again and anchored in the same place, and spent the whole day here. Dr. G. and the visiting "biologists" went ashore and spent the day; but as it was drizzly and windy the rest of us stayed on board. They found a paper at a hotel telling of the loss of the cruiser "Brooklyn" off Cuba. Do you remember dearest, last year the day we went to Marblehead seeing the "Brooklyn" lying there? They also saw a notice in some Eastern (Philadelphia) paper that the Albatross had been lost in the Hong Kong typhoon, off the China coast. I was awfully afraid you might have seen it and been worried dearest, but of course you know we were up at Sakalim then, and not near China at all. You must have some letters of mine dearest dated after the typhoon anyway. I think it is a shame to circulate reports like that anyway dearest as it might worry so many people. Well another day has passed dearest dearest dearest wife and there are only 4 days between today and the day we arrive in Yokohama. How I wish they were over precious. I wouldn't go on another trip like this for millions. Good night dear sweet wife. "Duck's rest" and pleasant dreams dearest. God bless you Mary.

Oct. 23. It was so windy and rainy today we didn't go out at all, but stayed at anchor all day. This is a rather rough anchorage, as a current swings us so we are broadside to the sea all the time, and so we get the full benefit of the waves rolling in toward the beach. The sea around the ship was all muddy today, with mud washed down by a river which empties into the sea right abreast of us. We had lots of visitors today in the shape of local fishermen and people from the town. Dozens came on board. As usual the main center of attraction was the "galley" (kitchen). Somehow or other wherever we go, the natives all cluster around the galley doors to watch the preparation of the grub. It was just the same in the Aleutians, and Crater says it was just the same in the south sea islands and in Mexico. The time is getting shorter now dearest; only 3 more days now precious, before we run into Yokohama. How I wish I could tell you how much I long to see you dearest dearest wife. Good night dear and "duck's rest" and pleasant dreams darling precious little wife. God bless you my Mary.

Oct. 24. We started out early this morning but the sea was so high we came right back again and anchored in the same place. It just poured all day. I don't think I ever saw it rain much harder. Two days more dearest: only 2 days now thank God! I never spent such a long week as this has been. Absolutely nothing happened today: we just loafed in the ward room all day as it was too rainy to do on deck. Well, good night precious precious little wife and "duck's rest". God bless my dear dear Mary.

Oct. 25. It cleared off about 5:30 this A.M. and has been just a perfect day ever since, only rather windy. We went out and took a couple dredge hauls, and the second haul succeeded in losing the whole outfit. The barometer was going down and the sea coming up, so we ran for Tokyo gulf, and are now anchored near Uraga, just inside the entrance. Tomorrow is the last day dearest and then we go 
into Yokohama to fix up ready to go home. We will start about Nov. 7 dearest and get into S.F. about Dec. 15. Good night dearest dearest dearest little wife. "Duck's rest" and God bless you dear Mary.

Oct. 27. Dearest dearest wife; this is our last day of work: we leave early this morning: we ran out of the place we were anchored last night, and took a haul but lost the net. I had just one more of that kind left, so I put it on, and everybody hoped it would be lost too, because then there wouldn't be any more, and we would have to quit; but that net just simply wouldn't tear. It went down, dragged along the bottom with the most exasperating smoothness, and came up again all whole time after time. The capt. said that when that net went it would end all work, but it wouldn't go. At 4 P.M. he said that would be the last haul anyway. When the net came up he ordered the men to stow all the dredging gear, and you ought to seen how quick everything went below. It beat sleight of hand. Even the ship's cook helped. Everybody rejoiced except old Gilbert. We all adjourned to the ward room and paired off and matched for a bottle of champagne, to celebrate the event. I matched with Prof. Snyder and stuck him. Tongue stuck Sindo. We were the only two who didn't get stuck. At dinner we had Dr. Mitsukuri, who has been living in the cabin, as a guest. He is Prof. of Zoology at the Tokyo University, and quite a big man, but doesn't say very much. He has been seasick most of the time since he has been on board. He said at dinner he was glad to see us drinking alcoholic liquor: he had no use for teetotalers: temperance men were much better. It amused us very much. We are steaming for Yokohama now, and expect to get there pretty soon now. We are going to fix the boat up and start home as soon as possible. I have just been up on deck and seen the lights of Yokohama blinking in the distance dearest and I felt $\underline{\text { so }}$ thankful that it is all over now except the run home. Six weeks more precious, but we shall be coming home all the time. I never realized the Pacific was so big before: it will take us 3 weeks to reach Honolulu from here with no stops. Dr. G. told me we were going to work on the way, but the captain squelched that little scheme. By the way, we learned last night that a steamer named Albatros was wrecked at Kowloon (near Hong Kong) in the typhoon a while ago, and most everybody lost, so you see there was a foundation for the report after all. That was the same Albatros which was up the Amir river when we got into Hakodate, which caused all our first mail to be sent to Vladivostok. Take good care of yourself precious, and if you get to Cal. before I do be awfully careful, won't you dearest? I know you will dearest dearest wife, so I won't worry. Good night darling little sweetheart and "duck's rest" and pleasant dreams dear dear dear Mary. God bless my perfect little wife.

Heaps \& heaps \& heaps of love \& kisses

From your most loving husband
Yokohama, Japan

Oct. 28, 1906

Dearest dearest sweetheart,

We anchored outside the breakwater last night, and came into the harbor this morning. Tongue went ashore right away for mail and I got two letters from you dearest dearest wife. I was so glad to get them. I am glad you had such a nice time up at Whiteface dearest; would it have been a nice place to do as we had been planning to do this spring there dear? Perhaps we can have a honeymoon there sometimes though. Is it nice country for camping out? I am glad to hear that Charlotte is "cured". I think the only trouble was that she thought too much about herself anyway, and I suppose the earthquake sort of gave her the idea that there was something else than herself in the universe after all. I am glad, too the Wolcott is better. It must be hard enough having him the way he is anyway. I wonder how Henry's "practice" is getting on. Does he still monkey with Dorothea? I can't help feeling sorry for him though, even although I think it is largely his own fault. That was rather funny about that notice in the newspaper about the new island in Bering Sea (Fig. 34). When Dr. Heath was on board, we were talking about it and Mr. H.[Hepburn] said he could believe that he had really seen it rise out of the sea: first he saw just a great mass of steam, then a speck of land under it, and later the whole island, rose into view. He put it in such a way that Dr. H. understood him to mean he had really seen it rise. When we saw Dr. H. take that view, we naturally followed it up, and stuffed him about it, never dreaming of consequences, and so were thunderstruck when Mrs. Hepburn sent the clipping out. She was mad at Mr. H's name being mentioned, because she knew all about the island, as he had written her and knew we hadn't seen it rise. I am going to look up the hotel this P.M. dearest, to see if I can locate Howard Waters. He ought to be in Yokohama about now. I suppose he will stop here first, as this is the chief place. It would be funny to find him out here, wouldn't it dearest? That was a funny thing, the new spelling list of Pres. Roosevelt's, wasn't it dear? It was just published a while ago in the Japanese papers, with all sorts of comments pro and con. It is awfully hard to have to wait until Dec. 15 isn't it dearest dearest dearest wife? But it isn't any harder for you than it is for me precious cooped up on this horrid ship all the time. Anyhow the start is made now darling so try to be cheerful dearest little sweetheart and I will try to too, although it does come mighty hard at times. We shall never be separated again shall we precious, but we will just live together just always won't we dearest and won't we be happy? Good night dearest dearest darling little sweetheart and "duck's rest". God bless you my perfect little wife.

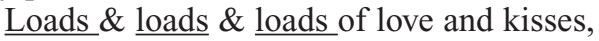
From your most loving husband 


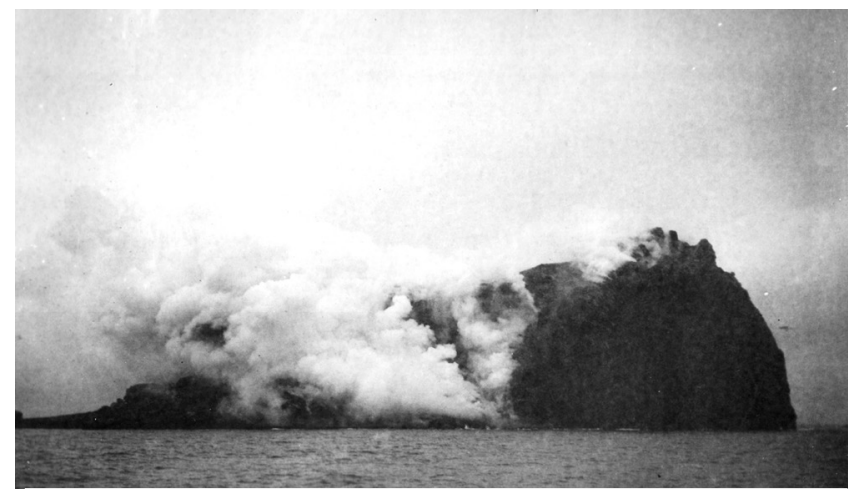

Figure 34.- Volcanic island emerging from the sea, near Bogoslof Island in the Aleutians. U.S. National Archives.

Yokohama, Japan

Oct. 28, 1906

\section{Dearest dearest sweetheart,}

Nothing particular happened today. We are anchored way out at Kanegawa, quite a distance from Yokohama proper, too far to go ashore, as it takes about three quarters of an hour. We are going into dry dock tomorrow morning to be cleaned up ready to go home. The harbor is full of ships now, and the cruiser "Cincinatti" is in here from Cheefu. We are going to sail a week from Saturday; that is, on Nov. 10. You just can't imagine how glad I will be precious. It does seem so long dearest since I have seen you. Be awfully careful in S.F. won't you dear? We hear very bad reports about robberies and holdups and things in broad daylight dear. Do be careful, won't you dear wife? Well, another day has gone darling, making one less now. Good night dearest dearest dearest wife, and "duck's rest" and pleasant dreams dear. God bless you Mary.

Oct. 29. We went into drydock at 7 this morning, and at 4 this P.M. everything was all done; all the barnacles and weeds scraped off, and the bottom painted with 2 coats of paint. This is the quickest it has ever been done. I was busy all the morning hauling things out of the lower lab so some new steam can be put in. These pipes are to let steam into the lower lab in case of fire: you just close down the hatch and turn the steam on in the engine room, and it squelches the fire right away. This evening I went up and took dinner with a Dr. Thompson who used to be the surgeon on this ship, but who is now on the "Cincinnati". He is greatly interested in snakes. It is a funny sensation being on a ship in drydock; you look over the rail and don't see any water, only the floor of the dock way down below you. It is sort of like being way up on stilts. The Jap. Steamer "Nippon Maru" is due tomorrow dearest from S.F. and I am looking forward anxiously for some letters from you precious. Well good night dearest dearest sweetheart:"duck's rest" and pleasant dreams dear. God bless you my perfect little wife.
Oct. 30. I went ashore today darling and got you something pretty nice. What do you suppose it is dear? The material for an opera cloak to wear to parties and things. You get them all ready to cut out and sew together. The doctor went along with me and thought it was a dandy. It is very heavy silk, all embroidered down the front and on the collar and cuffs. It cost $\$ 23$ dearest, but this same man gets $\$ 125$ for the same thing in New York. If you don't like it when you see it darling, we can sell it at least for what it cost. It is the latest London style, and comes from Chefoo, where silk and labor cost almost nothing. He gives me a pattern to cut it by too. It is the very best Chinese silk. I guess I have been to about every silk store in town the last 2 days looking for one dearest, but I think you will like this one better than any of the others.

Later. Have just got two letters from you dearest, and I was so glad to get them. I am just dying to know what it was you sent me at Honolulu dearest. It was so dear of you. I would have sent you lots of things from here, only you see it is outside the U.S. and it would have been an awful job for you to get them. Crater got a letter today dearest saying that things were awful in S.F. now. Men and women were held up and killed every day and night. Do be careful dearest dearest wife, won't you? and Please don't go over to S.F. or wandering about in unfrequented places: but I know you will take care of yourself darling. I don't mean to be bothery dearest but you know you do mean so much to me dear I just can't beat to think of your taking any risks. Hepburn got a letter saying that Arthur has got diphtheria. Must be awfully hard with him so far away. It gave me quite a scare dearest. What if you should get sick dearest and me way out here? Anyway we are coming home now darling and when I get back we will never be separated again will we? I am mighty glad Aunt Mary has a room for you dear. Give my love to all of them dearest. I always mean to be remembered to people, but always forget it. I am going to close now dearest so as to get this letter in the mail in time to catch the ss "Dakota" which leaves tomorrow morning. Good night dearest dearest little wife and "duck's rest" and pleasant dreams. God bless you dear dear Mary.

from your most loving husband

Yokohama, Japan

Oct. 31, 1906

Dearest dearest dearest sweetheart,

I went out today and had lunch with Dr. Thompson on the cruiser "Cincinnati". He showed me all over the ship. It is much bigger than this one, with a big crew and lots of guns. It was very pleasant at lunch. There are fourteen or fifteen officers there in the wardroom, and of course the warrant officers (like Prine and the rest) eat in a different place, so it makes it all the pleasanter. Mr. Evans, 
the executive officer knew lot of people I do in Venezuela and W.I. He comes from Chelsea, and knows all about Boston and that vicinity. He is the same rank as our skipper. This morning they sent a messenger over that our paymaster was ordered to Washington to wait orders for another ship which pleased him greatly. The men have got a Chinese record for their graphophone which is the weirdest thing, with the most blood curdling shrieks and yells in it. They have been playing it all day to Metters intense disgust. The Chinese steward says it is a very sad piece. It certainly does sound as if somebody was being tortured. They are painting up the ship and gilding the bow and stern ornaments, so we ought to present a fine appearance when we go to sea. They are going to fix up the wardroom too. The doctor is still amassing curios: he has bought about $¥ 400$ (\$200) worth since he has been here this time. Crater bought 8 kimonos and a dinner set of 165 pieces, not to speak of all sorts of other things. There is the greatest indignation here on the treatment of Jap. children in S.F.; you know they wouldn't let them in the schools. The local people are just full of it. Americans are under a cloud here just now, so the men when they go ashore take along a suit of ordinary clothes and sneak into a hotel and change them, and then pose as Englishmen, and get treated lots better. The weather was fine today, and you could see Fuji plain. It hasn't any snow on it now, so it doesn't look so imposing. Well good night dearest precious little wife: "duck's rest" and pleasant dreams darling. God bless you dear Mary.

Nov. 1. Went ashore today and ordered a tuxedo dearest. I went to the doctor's tailor, as he is the best one, and charges 8 yen less, because he knows we are sure to pay. The others charge 53 yen (and he does regularly) but this chap makes a special price of 45 yen to the doctor, and did to me too as a favor to the doctor. He says the reason they have to charge 53 yen is that they always figure on a certain percentage of unpaid bills. He is making a tuxedo for the doctor and for Hazard, and seems to be an A1 man. I also got a Nov. 12 present for you precious: that is ordered it, as it has got to be made up. I do hope you will like it dearest. It wasn't extravagant precious, but I bet it is better than any of your friends have. Today coming back in the launch a couple of the sailors who were coming back from liberty were awfully drunk, and one of them kept pestering Crater by pressing a chew of tobacco on him. Crater would squelch him, and he would say, "Excuse me, Mis Crater, thash all right, hav a chew of bacca?" Crater got ripping mad and I nearly split. Thank God another month has gone dearest dearest dearest wife. 9 days more and we shall be homeward bound. I am just dying to see what you have sent me at Honolulu dear. Good night dearest precious little wife: "duck's rest" and pleasant dreams darling. God bless you my dearest precious perfect little Mary.
Nov. 2. I just got your letter mailed Sept. 28th dearest. Somehow dear, every mail I seem to be more and more anxious for your letters precious. I do love you so Mary and I love you more and more and more all the time darling. I forgot all about its being Betty's birthday on the 25 th. That was a great scheme dearest, giving her a postal in a frame. They are rather pretty postals, aren't they? I am going to lay in a supply for you, precious. It is great stunt using them for Christmas presents as they don't cost much. (5 sen, or $2 \frac{1}{2}$ cents apiece) and some of them are real pretty. I just got a letter from Betty asking me to lay in a supply for her too. I shall bring them all to you dearest, and you can pick out those you don't care so much about and send them to her. You must have had a nice time at Betty's birthday dearest: how I wish I could have been with you. Do you remember the dinner we three had at the Touraine just before we were married dearest? Isn't it great your mother has got confidence to go around by herself at last? It takes a big load off my mind darling. I'll bet your coming to Cal. had lots to do with it dearest. I am so glad she has changed dear. When I come to think of it I don't wonder she was so nervous last winter dear, do you, with all the trouble she had? I am anxious to see her again. Isn't it funny about her and Betty? So Aunt Emily said you looked "sweet as peaches" did she? I never saw you when you didn't dearest Mary. Pa writes me you look better than ever since your European trip. I am so anxious to see you dear sometimes it seems as if I just couldn't wait. From what they say, you must be prettier than ever dear Mary. I don't think that is possible darling, for I can't imagine it: you are the prettiest girl I ever saw, and I don't see how you can be improved at all dear. I can't see how I was ever so lucky to deserve you, Mary, the prettiest and dearest little girl that ever was. I have been busy all day getting boxes on board which were stored on shore, and so haven't left the ship at all. Tomorrow is the Mikado's birthday, and I expect there will be great glorifications ashore. A big Jap. battleship has just come in ready to fire a salute tomorrow. Well good night precious darling little wife; "duck's rest" and the pleasantest dream dearest. God bless you Mary.

With heaps $\&$ heaps $\&$ heaps $\&$ heaps of love From your most loving Austin

Yokohama, Japan

Nov. 3, 1906

Dearest dearest wife,

Today was the Mikado's birthday and the ships in the harbor were decorated with flags. At twelve o'clock the Jap. battleship "Katori" and the "Cincinnati" anchored just outside the breakwater fired the national salute of 21 guns. The whole town was decorated with all sorts of flags, mostly Japanese, and the electric cars had each 4 flags, two in front and two behind. Nothing special happened. I went 
to the tailors to observe the growth of my tuxedo you wanted me to get dear, and met Dr. Thompson, and visited the aquarium here together. It was really a mighty good one. It is a speculation all built and owned by a man who charges 2 sen ( 1 cent) admission and sells the fish and things in it. We saw some of the funniest goldfish you can imagine. One was one of those triple tailed telescope eyed ones. Jet sooty black, with the tails about 3 times the length of the body. It reminded me of a widow with weeds. Well, good night precious little darling and "duck's rest". God bless you my dear dear wife.

Nov. 4. Nothing particular happened today: it wasn't very pleasant, so I didn't go ashore. Metters caught a couple of men last night trying to sneak aboard unobserved about 3 o'clock and put them in the brig for going ashore with out first going through the formality of asking permission. Another man ran away, but the police are after him and we expect him to return soon. The men spend most of their time up on the forecastle telling each other of experiences they have had ashore, or trying to borrow from each other. They can't go ashore any more, as none of them have any money. We are all invited up to Tokyo tomorrow to an informal luncheon at the Imperial University. The invitation raised a row in the wardroom as it included only commissioned officers, and of course Crater, Hazard, Metters, and Prine were omitted. Wouldn't they (cut) a great figure at a university or any other respectable gathering; Metters and Crater would be certain to get full immediately. Hazard was mad about it, but he claims he is a commissioned officer: so he is, strictly speaking, but there is a huge gulf between those of his rank of "chief boatswain" and those from Annapolis, which he can't seem to appreciate. He is the lowest anyway. Well, good night dearest precious little sweetheart: "duck's rest" and the pleasantest dreams darling. God bless you Mary.
Nov. 5. Went up to that lunch at Tokyo today and met a whole lot of professors in the Imperial University. We had a fine time. Dr. Mitsukuri and Dr. Goto who were on board with us were there. Tokyo is an enormous city: about $1 \frac{1}{2}$ million people, and practically all the houses are only one story or at most two, so you can imagine the space it takes up. We passed the park around the Mikado's palace in going up to the Univ. The Univ. is a very large one, and has about 9500 students: about 3000 Chinese and the rest Japs. It is very pleasant. We had lunch in the club, and it was a mighty nice lunch too. I sat next to a Jap who had been all over Europe and the States, and had been to Harvard. He spoke English perfectly, so it made it mighty pleasant. We got back about 6 , just in time for supper. Well good night dearest dearest dearest sweetheart. "Duck's rest" dear. God bless my noble little Mary.

Heaps \& heaps \& heaps of love and kisses

From your most loving Austin

Yokohama, Japan

Nov. 3, 1906

Dearest dearest sweetheart,

Just received your dear letter mailed Oct. 15 from Newtonville. We are nearly all fixed up now to leave for home. The boilers and machinery have been all fixed up and we are going to coal tomorrow. Nothing much has happened today dearest. I went ashore this P.M. and visited the tailor to try on my new tuxedo. One of the sailors ran away and we have sent the police after him. Hanson stayed about 5 hours over his leave. They have been painting the ward room, and it shines like a new dollar. Almost everybody has got paint on him except me. Tongue spoiled his derby coming out through the water tight door leading to the "dog house" where his room is: he smashed it against the top of the door and got it all paint besides. We have been awfully bothered with flies lately, but it is all right now: they have all stuck to the fresh paint. Somebody made Metters a present of a sickly looking white rabbit. He keeps it up by the stack in a box. The Captain says Metters gets the worst looking lot of pets of anyone he ever saw: if he doesn't buy them himself he gets them given to him. Three days more precious, and then we start for home. These three days seem longer than a whole month did a while ago dear. How I do long to see you precious wife. I do love you so Mary. Well good night dearest dearest dearest wife: "duck's rest" and pleasant dreams darling. God bless you my dear dear Mary.

Nov. 7. Went up to Tokyo today to visit the Imperial Fisheries School. They have an enormous great building devoted entirely to the teaching of the various trades connected with the fishing industry: making of nets, extraction of the various kinds of fish, whale and seal 
oils, preservation by drying and canning of various fish products, making of rope and testing its strength, etc., and navigation. They teach all sorts of other things too, especially chemistry, for which they have a number of finely equipped laboratories. They also have a room fitted up with compasses and all sorts of things for teaching navigation. They also have a number of (about 7) boats, ordinary row boats and whale boats so as to show the boys how to use them, and also a schooner, fitted up for fishing on which the boys take cruises. We had lunch served in Jap fashion, of wholly Jap things: raw fish of two kinds, boiled lobster, fried eels and rice, green tea, a sort of paste made from fish, and another sweetish paste made of chestnuts, and various other things. They gave each of us, as an appropriate present, a purse made from the foot of an albatross, beautifully tanned. I got back to Yokohama at about a quarter past 4 . Two days more dearest dearest wife and we start home. We are not going to do any work on the way, so we ought to be in Honolulu about 17 days from Saturday (the 10th). Do be awfully careful of yourself won't you precious little wife. I can't help feeling a little worried about you darling from the reports we hear of "Frisco. Well good night precious precious little wife: "duck's rest" and pleasant dreams dear. God bless my noble little Mary.

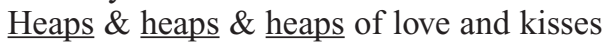
From your most loving A.

\section{Yokohama, Japan Nov. 9, 1906}

Dearest dearest sweetheart,

This is my last letter from Japan, as we sail early tomorrow morning for Honolulu. Everything is ready for sailing now: we have coal in sacks along each gangway, leaving only a narrow passage forward, all around the ward room skylight, leaving only a small passage to go into the cabin, and all over the forward deck, leaving only a narrow passage leading up under the forecastle head. You can imagine it makes getting about rather difficult. Sindo has obtained a job with a Japanese development company in South America, and is going to Chile instead of coming home with us. Dr. G. wants to do some more work out here, so he is going to stay and come home on the "Nippon Maru", sailing on Dec. 1. By the way, do you remember I told you about a caricature one of the sailors made for him, of him in a bottle and a big shrimp with glasses on and a book in its claws looking in at him? It was pinned up in the lab. And the next morning had disappeared. I supposed he had seen it and got mad and tore it up: but Dr. Thompson told me he was tickled to death with it, and had preserved it carefully and shown it to everybody. Funny, wasn't it, especially after he had got so mad about that cockroach the men put in the bottle with the deep-sea label and placed with the fishes. It has been just glorious weather ever since we have been here except today, when it is cloudy. It has been sunny every day, and nice and cool: regular October weather. I got a letter from pa the other day in which he says that anything I may have bought here which we would rather part with when we get back he will buy them from us dear. Isn't that nice of him. The tailor brought your opera clock aboard yesterday. It is a beauty: he says they cost $\$ 125$ in N.Y. It is embroidered down the front, with a wide embroidered collar and cuffs. Of course it isn't made up, but I got a pattern with it to cut it by, and 7 yards of silk. It is the most beautiful heavy and thick pongee, and is washable. I am dying to hear what you will have to say when you see it, dearest. I got a letter from Knowles in Fiji the other day. He seems quite happy now, although he doesn't like the place any more than he did at first. He says that it is the height of the dry season now, but in 13 hours they got 26 inches of rain, and furious thunder the whole time. When you realize that the total rainfall for the year at home is only 42 inches you can realize what that means: more than 6 months of rain at home condensed into half a day. Must have been rather moist, mustn't it? I got 5 dozen of those postals for you yesterday darling. I tried to make the best selection I could. Some of them are very pretty, and some I got to show the customs of the country. You can look them over and can give Betty those you don't care about so much. I got a few duplicates, but there were so many pretty ones I thought the best way to do was to get an assortment. The sailors are all hopelessly "broke" now, and most of them have sold all the curios they have been collecting so far to get money to go ashore: many of them have sold all their clothes except what they have on in addition, and all of them are doing their best to raise loans. Mr. Snyder says they strike him at the rate of about 3 every hour: he lives in one of the forward rooms, so he is 'specially liable. One of them has struck every officer on board at least 3 times, but hasn't raised a cent. This letter will leave tomorrow precious just about the same time we do. Au revoir dearest precious little darling, my next letter will be from Honolulu. Take the best of care of yourself dearest, won't you. God bless my dear dear wife.

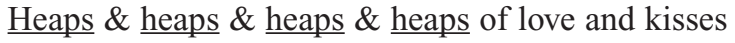
From your most loving Austin

Nov. 10. Dearest dearest sweetheart: We got under way at 10 this A.M. It has been a beautiful day today, with a brisk breeze and just as clear as could be. Mt. Fujiyama showed up in fine shape: even at sunset when we were far off the coast and could only just make it out, the beautiful cone of Fuji, tipped again with snow, stood out boldly against the red sky. When any ship starts home after a long cruise, they hoist a very long pennant on the aftermast (do you remember the one the "Oregon" had in San Francisco harbor), so as to show they are homeward bound. The men all begged to have ours hoisted: so Larsen, the old quartermaster, got it out and just as we 
started Metters pulled the cord and it unfurled from the masthead and floated way out behind us, showing every ship in the harbor that we were homeward bound. It is so long that unless there is quite a breeze it trails in the water behind the ship. One of the engineers got left behind: he went ashore for a final drunk last night, and didn't show up before we sailed, so we left him. The captain wrote a note to the consul telling him that he is not entitled to any consular aid being a straggler from the naval ship. Crater was tickled to death to have him left behind, as he was a worthless specimen. They made a survey of his belongings this P.M. and found 2 cheap teasets, a whole lot of brand new clothes. He also has a deposit of $\$ 500$ with the paymaster. The clothes will be sold at auction, and the money turned over to the naval hospital fund. We expect he will get a passage on some steamer and reach Honolulu ahead of us, so as to greet us when we arrive. Although not exactly rough, it has been pretty jumpy since we started, so that quite a number are down and out. Dr. G. is stopping in Japan until Dec. 1, and is coming home on that date by the ss "Nippon Maru". Sindo also is staying in Japan, and is going to join a Jap. development company in So. America, going to Chile very shortly. I understand he will be married before he goes. We are at last homeward bound precious little darling wife, and I have looked on Japan for the last time. We are well out to sea now dearest, and making for Honolulu as fast as we can go. Be careful of yourself dearest, won't you? Good night dearest dearest sweetheart: "duck's rest" and pleasant dreams dear. God bless you my perfect little Mary.

Nov. 11. Just think what happened two years ago tomorrow dearest!! Can you realize it was two long years ago precious? It seems like yesterday to me. I have a nice little present I just had made for you, dear Mary, as a little reminder of my first introduction into heaven; for dear wife it is heaven for me to be with you and to be able to hug you and kiss your pretty face dearest; a sweeter heaven than I had ever supposed could exist; and the more I experience it the sweeter it becomes precious. Nothing whatever happened to day: it was moderately rough all day, and all the "down-and-outs" remained in that condition. It was rather squally, with occasional spatterings of rain and a good breeze from the north. The only excitement was when Tongue revived long enough to play me a couple of games of cribbage, and I got licked. We couldn't play chess or checkers, because the men wouldn't stay on the board. Another gone dearest dearest dearest wife. Do be careful of yourself for God's sake Mary. Good night precious sweetheart: "duck's rest" and pleasant dreams dear. God bless you my dear dear Mary.

Nov. 12. Just think of two years ago today dearest precious little wife! "What do you think they'd think?" We must have another rehearsal when I get back, mustn't we? That was the happiest day I ever knew up to that time darling, but it was just nothing to the happiness I feel when I am with you now dear. Somehow I appreciate you more and more all the time dear sweetheart. This trip has been a sort of miserable gap darling, sort of like a bad dream ever since I left "Frisco. We will never be separated again will we dear dear dear wife? The more I think of you Mary, the more I wonder how such a beautiful perfect little woman could ever have loved me. I know I never deserved it precious but I am going to do my best to try to some day. It has been quite rough all day, rougher than yesterday, with a half a gale behind us so we have been scorching along at a great rate. We took a big circle northwards to find favorable winds and we seem to have found them. Nothing special happened; most of the people were pretty miserable and didn't feel at all conversational. Good night dearest dearest dearest sweetheart: "duck's rest" and pleasant dreams darling. God bless you my precious Mary.

Nov. 16. It has been so rough ever since Monday it was impossible to write, or, in fact, do anything. The last 3 days we had a very high sea, on the port quarter, with a good gale blowing, so we could only risk one sail up with squalls every couple of hours to add to the interest. You wouldn't believe how this craft could roll: the top of the rail on my side of the ship went nearly two feet under the water once, and the water just poured over the top of it every few minutes. The waves would break on the port side of the ship, and fly clean over, so the hurricane deck was soaking wet all the time. One of the life boats got full to the brim twice. The gangways were like swimming baths a good part of the time, full to the rail. I shut up my room tight, and have been living in the laboratory, and sleeping in a hammock slung under the ceiling. Such a thing as sleeping in a bed is of course out of the question. You ought to have seen the wardroom. They covered up the skylight with a big tarpaulin, but when a wave came it just sloshed up under the edge, lifted up the skylight, and came right in. The wardroom was anywhere from 2 $\mathrm{ft}$. deep with water down to just enough to slosh around and make it slippery. The water got into the electric light main conduit and dripped down from them everywhere. Tongue's office got full and the water leaked down into Hazard and Prine's rooms. Crater's room is a soggy mess thanks to a leak in the deck. Luckily dearest my room is tight and dry, only a little water coming under the door when the gangways are full which is easily mopped out. It never gets more than an inch or so high. The Jap. boys have been waiting on table barefoot and splashing about in the water as they moved. Often they would slip and slide clean across the room. The one named Tommy (he was here when you were, dear) has acquired remarkable dexterity. Yesterday he was passing two dishes of vegetables, when he slipped and slid on his back half the length of the room, keeping both dishes right side up all the time. Day before yesterday he was especially unlucky. A big wave broke into the galley and 
swept all our grub off the stove. The steward opened up some sardines, but the boy in passing them slipped, and down went the platter on the floor, sardines underneath. For dessert we had canned plums; or I should have said intended to have canned plums; for he was just clearing the port end of the table, when she gave a mighty roll, and the plums, juice and all shot out of the dish and plastered themselves on the wall clear across the room. Of course liquid nourishment was impossible: those who indulged in beer had to drink it out of the bottle, and keep the bottle in their breast pockets until the moment of reference came. Our china ware is seriously reduced now: a dozen or so plates broke in a single roll; and glasses are so few that nobody can have an extra one for beer: in fact they have to be eked out with small jelly tumblers. Poor "Buck" has had a bad time of it: he hates to get wet, so he has spent the time in the engine room, standing always in one spot, and looking awfully unhappy. Metters rabbit was washed off the top of the house, and was discovered swimming about the starboard gangway: its ears were all that were above the water. It was washed down again, and was found up under the forecastle, cuddled up alongside of its mortal enemy the cat, but too scared to move. The sea is moderately fast dearest, and it will probably be fine weather in a day or so. Good night dearest precious little Mary: "duck's rest" and pleasant dreams. God bless you dear wife.

Nov. 17. It has been much pleasanter today, with less wind and sea, and it has been warmer too. Nothing whatever has happened all day. It is one day nearer Frisco, precious and we have made good time. Good night dearest dearest dearest little wife: "duck's rest" and pleasant dreams dear. God bless you dear dear dear Mary.

Nov. 18. Fine weather today and nice and warm and sunny. Everybody spent the day in getting dried out after the recent wettings we have had. Nothing whatever happened: I just read all day. The ward room is a sight; you would never think it had ever been painted at all, but they say it can be cleaned up. Good night dear dear dear sweetheart and "duck's rest" God bless you Mary.

Nov. 19. Beautiful weather today: the water is beautifully blue, and a lot of flying fish came on board early this morning. Nothing has happened all day, and I haven't done anything but read. One day more gone precious. Good night darling little wife: "duck's rest" dear. God bless my little Mary.

Nov. 20. We had a fine breeze today, so all the sails, both the square and the "fore and aft' were set, and we skated along at a great rate. Nothing whatever happened, but we are eating up the distance to Honolulu in a most satisfactory manner. One more day has gone precious little sweetheart. Well good night dearest dearest dearest wife: "duck's rest" and pleasant dreams dear. God bless you my precious Mary.

Nov. 21. Today has been a sad day for all on board. The captain fell overboard and was lost at half past seven this evening. It has been a fine day today, fairly smooth sea and a fine breeze on the port beam, and we had all the sails set and were making 11 knots and over, which is doing very well for this boat. The day had been absolutely uneventful: the table had just been cleared and all the chairs were lashed to it to prevent their moving about. I was standing at the starboard (leeward) end of the wardroom table talking to Mr. Hepburn and Mr. Snyder, who were sitting on the transom in front of me, about marine engines, when we heard a cry. It was faint and indistinct, but we all stopped talking and Mr. Hepburn said "What's that?' Immediately after we heard the paymaster, who was on deck, cry "Man overboard", and all rushed up on deck. They were taking in the big mainsail and the other sails forward, and were putting the ship about to go back to hunt for the lost man. I gave a hand to the ropes to help the men with the sails, and when that was done, Mr. Hepburn called a muster of the crew to find out who was missing. We had seen practically everybody at the ropes, and were beginning to think it might be a mistake. After that Mr. H. called for a muster of the officers and then we realized that nobody had seen the captain. Mr. H. the doctor and I went into the cabin, but he wasn't in there, and then somebody discovered that the netting that runs around the poop just under the rail was carried away in one place between two stanchions (the uprights which hold the rail), and a steamer chair with a couple of legs broken was right side of it. Apparently he was sitting in the chair on the windward side, and when the ship gave a lurch the chair had slid clear across the deck, and shot him off through the wire netting into the sea. The first cry we heard was probably his as he fell into the water. A life buoy was thrown as soon as it was realized a man was overboard, but it would have been practically impossible for him to have found it in the dark. We got back to the place as soon as we could, and have been playing the search light about ever since in the hopes of picking him up: but it is nearly one now, and he could hardly have kept himself up so long, especially as he had all his clothes on. It must be an awful death to die way out on the ocean all alone, mustn't it dearest? and just as he was coming home to be examined for promotion too. You needn't be at all alarmed about me precious, I always take special care of myself darling, so don't worry, will you? You take awfully good care of yourself, won't you precious little sweetheart. Good night dearest dearest dearest wife: "duck's rest" and pleasant dreams dear. God bless you Mary, my dear dear dear wife. 
Nov. 22. We drifted and sailed slowly back and forth all last night until 6:30 this morning, trying to find the captain, but it was no use, so at 6:30 we got under way again for Honolulu. An inventory of his things was begun this morning. He lived in Plattsburg, N.Y., and leaves an old mother and various other relatives. The sea has been rather rough today, considerably rougher than yesterday, and with more wind. We are going to make all the speed we can for Honolulu. Mr. Hepburn is captain now, and will probably take the ship home. We rather expect he will be made permanent captain, and another officer will sent out to fill his former position. Nothing whatever happened today: nobody has felt like saying much, and the rough sea made it rather uncomfortable. Well good night precious little darling sweetheart. Take the best care of yourself dearest. "Duck's rest" and pleasant dreams dearest dearest dearest wife. God bless you Mary.

Nov. 23. Rather rough all day today, and we pitched and rolled about like anything. At about $4 \mathrm{pm}$ sighted the island of Kauai, and have been watching it ever since. It seems good to see land again after such a long trip. We shall be in Honolulu early tomorrow morning, and I shall get some more letters from my own darling precious wife. It will be great to be somewhere where we don't have to hang on to something all the time, and where we can get a decent sleep without fear of toppling out of our bunks. Well good night dearest dearest dearest wife: "duck's rest" and pleasant dreams. God bless my little Mary.

Nov. 24. We got in at 9:30 this A.M. and tied up to the Naval dock. Our flag, the flag at the naval station, and the flags on the American and British vessels in port were half-masted, and at 12 they fired 7 guns from the station in honor of Capt. Garrett. Tongue immediately went up after mail, and came back with a mule cart and 20 bags of it, mostly newspapers. I got 10 nice dear letters from you dearest. I am awfully glad you came out to Cal. dear, I don't see how I could have stood it if you hadn't. But do for God's sake take care of yourself Mary dear dear wife: we hear awful things about murders and robberies and hold ups in S.F. and Oakland, even in daylight. I have been awfully worried sometimes dearest, but you will take care of your precious little self won't you? It has been drizzling most of today, but the sun was shining through it. It is nice and warm, but not hot like the West Indies. Tongue and I took a stroll ashore and found it a very nice and up-todate town and thoroughly Americanized. We've had the pleasure of indulging in some fine ice cream sodas, the drug store here being just the same as they are at home. When we got back to the boat we found that I had a couple of visitors. I don't know who they were, but I think one was a man I used to know in Barbados. We learned today that Harvard got licked again. Hard luck, wasn't it? They have fine electrics here like those at home. I am going to cable when we are going to leave precious. The trip will probably take about 10 days, so you can expect me 10 days after you get the message. I shall come direct to Aunt Mary's to hunt you up darling, as I couldn't think of you in S.F. for anything. I shall get away from the ship as soon as we get in, so there won't be any delay. I don't know whether we will go to Sausalito or Mare Island. Take care of yourself precious won't you? We are due about Dec. 15. We had exceptional luck coming from Yokohama, and got here nearly a week before we thought we would, but the continuous bad weather shook the engines up considerably, so our repairs will have to be extensive. Crater is one of the best engineers in the service, and manages everything in fine shape. I am sending you the account of Capt. Garrett's death as it appeared in the local paper. It is a very good account. Well good night dearest dearest dearest little sweetheart: "duck's rest" and pleasant dreams dear. God bless you and keep you safe dear Mary.

Heaps \& heaps \& heaps of love and kisses

Austin

Honolulu

Nov. 24, 1906

Dear Papa,

Arrived here this morning after a very rough passage of 15 days. Fortunately, the wind was behind us or on the beam all the way, and helped us considerably, but we rolled and pitched so that it was very uncomfortable, and we shipped great quantities of water all the time. The officers' quarters were from an inch to a foot and a half deep with water, and the waiters had to go about barefoot with their pants rolled up. A large part of our crockery was smashed. We had one unlucky accident on the night of the 21st: the captain was sitting up on the poop smoking a cigar after dinner, when the ship gave a heavy lurch and the chair slipped clear across the deck, and threw him through the rail (tearing a part of it out) into the sea. All the sails were set, and as we have square sails on the foremast, it took quite a long time to come around with the gale that was blowing. We searched everywhere with the searchlight until 6:30 the next morning, when we gave up. We are tied up to the naval wharf here, and all the flags about are half-masted as well as ours. They fired minute guns from the station this noon for him. We expect to stay here about 10 days, and then leave for S.F. under the former executive officer as captain.

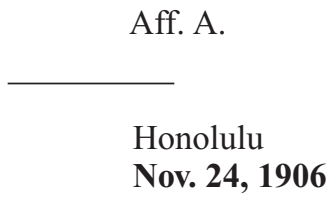

Dear Mama,

We got in this morning, after a very rough trip of 15 days from Yokohama. That was very fast for this craft how- 


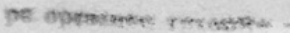 \\ POSTALTELEGRAPH

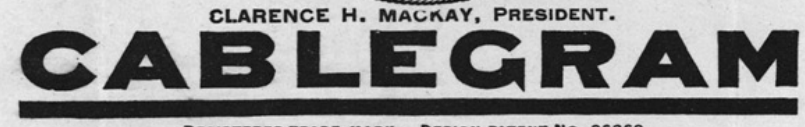

The Postal Telegraph-Cable Company (Incorporated) transmits and delivers this message subject to the terms and conditions printed on the back of this blank,

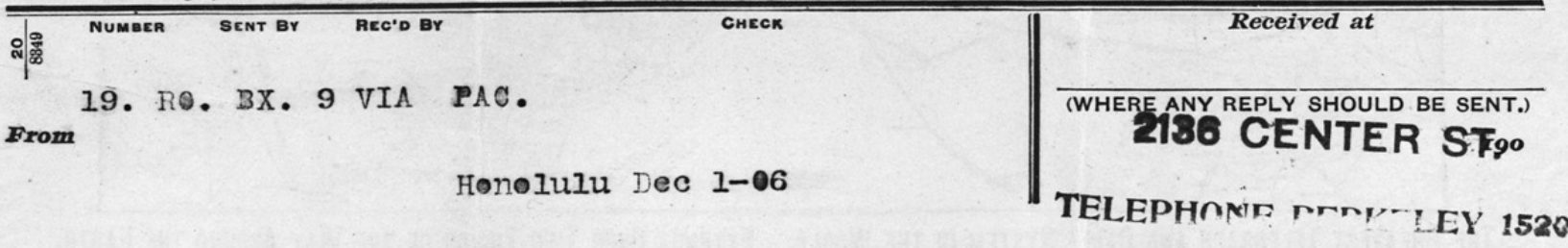

Mrs glark;

2335 Gedar St, Berkeley, Gal.

We Sall Tomorrow.

2-50Pra.

No Inquiry respecting this message can be attended to without the production of this paper. Repetitions of doubtful words should he ohtained thronsh the Comnanv's offices. and not bv DTRFCT annlieation to the sender.

Figure 35.-Cablegram from Austin Clark to Mary Clark, 1 December 1906. Smithsonian Archives.

ever, as we hardly expected to do it in less than 20 days; but what wind we had was mostly behind us, and helped us considerably. On the evening of Nov. 21, when about 500 miles from here, the captain, who was sitting up on the poop, was thrown over board by an exceptionally heavy roll. We had all the sails set, so it was hard work to bring the ship around, and we must have run a mile a more before we could stop, as it was blowing a gale, and we were running almost before it. Everybody gave a hand at the ropes bowswain, officers, and firemen and all, so we finally got her around and headed back; but the captain could hardly have lived for minutes in the sea that was running. We stayed there all night hunting for some trace of him with the searchlight, but couldn't find any, and got underway again at 6:30. When we got in here, the flags at the naval station, and on the U.S. and British ships in port were half-masted, and at noon 7 guns were fired at the naval station in the captain's honor. The executive officer, Lieut. Ar- thur J. Hepburn, is now captain, and will probably bring the ship home. He is a very nice man, and very popular on board. He is about 28 years old, and served in Cuba during the war. His wife and two little boys were on board during the fire in S.F. The two youngsters are about the cutest I ever saw, and were great favorites with everybody. We expect to be in S.F. on Dec. 15, as we need 10 days here for refitting

Aff. A.

Honolulu HI

Nov. 25, 1906

\section{Dearest Dearest Sweetheart}

I went to the Post Office early this morning to get the present you sent me dear. Wasn't it sweet of you to think of it? It is just the best present you could have sent especially 

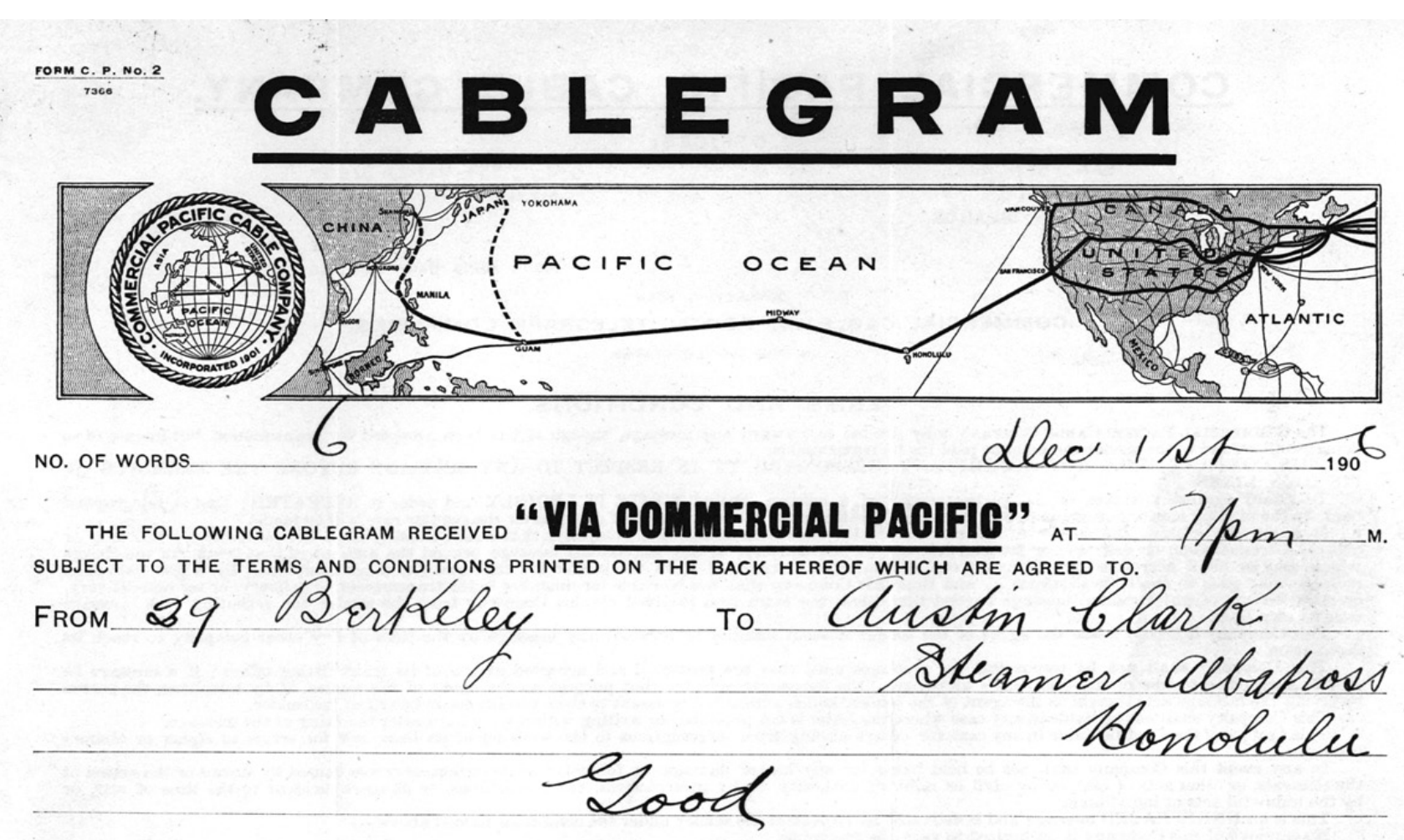

Figure 36.-Cablegram from Mary Clark to Austin Clark, 1 December 1906. Smithsonian Archives

the dear little picture inside. I do just love chocolates (remember the poker games we used to play for them 8 years ago?) and these were simply fine: just as fresh as when they were made, too. I hadn't so much as seen one since I saw you last dear. I forgot to say I went down to the P.O. to get them yesterday, but it was closed, being Sat. P.M. If you only like my present for you half as much I shall be tickled to death. We haven't done a thing all day today but loaf around and read and watch the sailors play ball on the wharf. It has been fine all day, nice and cool, much cooler than I ever saw it in the tropics before. I am going to look up some people here tomorrow. Well good night dear little precious wife: "duck's rest" and pleasant dreams dearest. Do take care of yourself won't you precious. God bless you Mary.

Nov. 26. I located a great friend of Glover Allen's today, a Dr. George C. Shattuck; and had a nice talk with him. He leaves tomorrow for Shanghai on a tour round-the-world.
I dropped in on a chap I used to know at Harvard who was in my class. Maybe he wasn't surprised to see me! He just got married 4 months ago, and is in business with his father. Then I looked up a man I used to know well at Barbados, who is doing agricultural work here; and I went up to tea with him. He has a nice house on a hill, with a beautiful view of a broad flat valley and the sea. His name is Lewton-Brain. This evening I went around to the University Club, and met some more Harvard men and spent a very pleasant evening. I gave Capt. Hepburn a couple of the chocolates you sent precious today and he was more than pleased: wanted [sic] immediately where I got them. We are going to sail a week from today for home. I will cable you (Fig. 35, 36) the day we start dearest, and will come and hunt you up just as soon as we get in. The big passenger ss "Korea" from S.F. came in today, and docked at the other side of the dock from where we are. It is an enormous big ship, 65 feet from the bridge to the water, where we are only 20 . There was 
a huge crowd on the dock to see her come in. The ss "China" also came in from Yokohama, and left just before supper for S.F. These last days dearest do drag awfully dear but it will soon be time to sail now, and we shall soon be united again precious never never never to be separated any more. I have felt so homesick the whole trip dear Mary I am afraid it has crept into my letters sometimes, although I tried to keep it out. One more day has gone thank God Good night precious little darling, and "duck's rest" and pleasant dreams. God bless you and keep you from harm dear wife.

Nov. 27. Mr. Hall, one of my old classmates came to dinner tonight and we reviewed old times and the subsequent changes. He is the chap I dropped in on Monday. It was pretty hot all day, so I didn't go ashore, except on the dock. The "Korea" left at noon, so there was lots of excitement on the dock. She goes to China and Japan. There are swarms of mosquitoes here. We were pretty well bitten up the first night, so the doctor made up some strong smelling stuff to put on our faces. The result was marvelous. It attracted them by the hundreds, and you can imagine the remarks we made to him the next day. However I had Hanson make me a net, so I am all safe from them anyway. Good night precious little darling sweetheart."Duck's rest" dearest. God bless my dear dear dear dear wife.

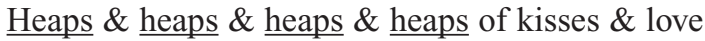
from your most loving Austin

Nov. 28. It rained like everything most all day today so I stayed on board and read. Mr. Lewton-Brain came to dinner, and we spent a pleasant evening swapping West Indies scandal. I find I know a lot more people there than he does, although he was there much longer. He says this has been the wettest day he had seen since he has been in Honolulu. Isn't it funny meeting a chap I knew so well in the W.I. way out here. One more day has gone precious. Good night dearest darling little sweetheart, God bless you dear. "Duck's rest" and pleasant dreams dear dear dear Mary

Nov. 29. It was Thanksgiving day today. The doctor concocted a huge punch for lunch which was fine. This P.M. Tongue and I went out to see the aquarium here, which is pretty good, and this evening I went up to Lewton-Brain's to dinner, and had a chance to wear my new tuxedo. He had some of the people up, and we spent the evening playing bridge, in which I am afraid I didn't shine. You must give me some instruction when we get together again dearest: perhaps we can interest Alice \& Charlotte in it, especially if we are to put up a dollar or so on each game: better ask Aunt Mary first and see what she says. It rained torrents today, but cleared off this evening. Good night precious little darling; "duck's rest" dear: God bless you Mary.

Nov. 30. Crater discovered that he can be all through today, so we are going to coal tomorrow, and leave Sunday. Isn't that great dearest? I will send a cable tomorrow as we agreed, anyway. We may possibly beat this letter home, as it can't leave till about the 7th. I am so impatient to start I don't know what to do. Just think dear sweetheart; less than 2 weeks now! The doctor went up to the custom house today and they told him that anything can be brought in intended for a man's use or for his wife's, provided they do not exceed $\$ 100$ in value: anything in excess of $\$ 100$ has to have the duty paid: so you see precious I won't have to pay any duty; my clothes won't come under the head of dutiable things anyhow. I was kind of afraid about the silks and things I got for you dear, as the duty is $75 \%$. I have been around the stores here and priced various Japanese things, and I find that they cost here about $21 / 3$ times as much as I paid: the price here is just a little more in dollars then it was in Japanese yen (50 cents). That opera cloak, though, is much higher than that. Well, good night precious little darling, and God bless you my dear dear dear dear wife.

Dec. 1. Just got your letter mailed Nov. 20 this morning. It came by the ss "Alameda". I was so glad to get it dear. I was afraid I wouldn't get another before we left. I expect we shall be in S.F. about the 12th dearest. I am glad it isn't so bad as we were led to believe in S.F. dear, but I am glad to know that you are taking care of yourself. I feel a lot relieved. I don't know what I would do if anything should happen to my little sweetheart. We sail tomorrow dearest and I am going right down to cable as soon as I finish this letter. Just think! Less than 2 weeks darling. Won't we be happy? Isn't it great your mother is so nice now; of course we will forgive her dear. Send my love when you write and give my love to Aunt Mary and the two sports. Au revoir dear dear sweetheart. God bless you.

$\underline{\text { Heaps }} \&$ heaps $\&$ heaps $\&$ heaps of love and kisses From your most loving Austin. 


\section{Acknowledgments}

First of all, we are indebted to the late Stella Clark, formerly of Sperryville, Virginia, who donated to the Smithsonian Institution in 2007 the Austin Clark papers that form the basis of this publication. Other members of the Clark family assisted in a variety of ways, and we are most grateful to Katherine K. Clark, Austin Clark's granddaughter, formerly of Oakton, Virginia, for her continuing interest in this project, and for financial assistance in processing the Stella Clark donation.

At the Smithsonian Institution Archives, Tammy Peters and Ellen Alers have been unfailingly helpful in response to our many queries and problems. We are also grateful to the staff in the U.S. National Archives; the Manuscript Division of the Library of Congress; the Stanford University Archives; The Academy Library and Archives, California Academy of Sciences; the archives of the Ernst Mayr Library, Museum of Comparative Zoology, Harvard University; the Widener Library Collections, Harvard University; the Schlesinger Library, Radcliffe Institute for Advanced Study, Harvard University.

We thank the Smithsonian Institution for financial and moral support during the course of our archival investigations. Lauryn Guttenplan, Associate General Counsel, Smithsonian Institution, provided valuable advice concerning ownership of the Austin Clark papers.

We thank our Smithsonian Institution colleague Dr. Jerry Harasewych for generously preparing for publication the small vignettes that appeared in Austin Clark's letters.

An anonymous reviewer of an earlier version of this article very kindly provided several valuable and constructive suggestions, all of which we have acted upon; if we had the opportunity, we would profusely thank this reviewer in person for his interest and help!
We owe special thanks to Marcel Chotkowski LaFollette, Jeffrey Stine, and Victor G. Springer of the Smithsonian Institution for their advice and support, and to Willis Hobart of the National Oceanic and Atmospheric Administration for his inspiring interest in all things Albatross, and for his endless patience over several years!

Finally, we thank Willis Hobart and Jacki Strader of the National Oceanic and Atmospheric Administration for their superb editorial work.

\section{Literature Cited}

Agassiz, A. 1888. Three cruises of the United States Coast and Geodetic Survey Steamer Blake. Houghton Mifflin, Boston, 2 vols., $64 \mathrm{p}$.

Agassiz, G. 1913. Letters and recollections of Alexander Agassiz with a sketch of his life and work. Houghton Mifflin, Boston and New York, $508 \mathrm{p}$

Allard, D. C. 1978. Spencer Fullerton Baird and the U.S. Fish Commission. Arno Press, N.Y., $424 \mathrm{p}$.

1999. The origins and early history of the steamer Albatross, 1880-1887. Mar. Fish. Rev. 61(4):1-21.

Anonymous. 1906. The California Academy of Sciences. Science n.s. 23(595):824-826.

1907. Dredging and hydrographic records of the U.S. steamer Albatross for 1906. Rep. Comm. Fish. for fiscal year 1906 and spec. pap. Bur. Fish. Doc. 621, 50 p.

Bowers, G. M. 1906. Report of the Commissioner of Fisheries for the fiscal year ended June 30, 1906. Bur. Fish. Doc. 72, 28 p.

Brittan, M. R. 1997. The Stanford school of ichthyology: Eighty years (1891-1970) from Jordan (1851-1931) to Myers (1905-1985). In T. W. Pietsch and W. D. Anderson, Jr. (Editors), Collection building in ichthyology and herpetology, p. 233-264. Am. Soc. Ichthyol. Herp., Spec. Publ. 3, Lawrence, Kansas. and M. R. Jennings. 2008. Stanford university's John Otterbein Snyder: student, collaborator, and colleague of David Starr Jordan and Charles Henry Gilbert. Mar. Fish. Rev. 70(1):24-29.

Clark, A. H. 1905. Birds of the Southern Lesser Antilles. Proc. Boston Soc. Nat. History 32(7):203-312.

1907a. Characteristic Kamchatkan birds. Auk 24:248-280.

1907b. Eighteen new species and one new genus of birds from eastern Asia and the Aleutian Islands. Proc. U.S. Natl. Mus. 32(1539):467-475.

1910. The birds collected and observed during the cruise of the United States fisheries steamer Albatross in the North Pacific Ocean, and in the Bering, Okhotsk, Japan and Eastern Seas, from April to December, 1906. Proc. U.S. Natl. Mus. 38:25-74.
Dunn, J. R. 1996a. Charles Henry Gilbert (1859-1928), Naturalist-in-charge and Chauncy Thomas, Jr. (1850-1919), commanding: conflict aboard the U. S. Fish Commission steamer Albatross in 1902. Mar. Fish. Rev. 58(1-2):3-16.

1996b. Charles Henry Gilbert (1859-1928), Naturalist-in-charge: the 1906 North Pacific expedition of the steamer Albatross. Mar. Fish. Rev. 58(1-2):17-28.

Hedgpeth, J. W. 1945. The United States Fish Commission steamer Albatross. Am. Neptune 5(1):5-26

Jennings, M. R. 1987. Frederic Morton Chamberlain (1867-1921), pioneer fishery biologist of the American West. Fisheries 12(6):22-29. 1997. John van Denburgh (1872-

1924), pioneer herpetologist of the American west. In T. W. Pietsch and W. D. Anderson Jr. (Editors), Collection building in ichthyology and herpetology, p. 323-350. Am. Soc. Ichthyol. Herpetologists, Spec. Publ. 3, 593 p.

Jordan, D. S. 1928. Charles Henry Gilbert. Science 67(1748):644-645.

Kline, M.-J. 1987. A guide to documentary editing. The Johns Hopkins Univ. Press, Baltimore, Md., 228 p.

Kostura, W. 1997. Russian Hill: the summit 1853-1906. Aerie Publ., San Francisco, 131

LaFollette, M. C. 2008. Science on the air: populizers and personalities on radio and early television. Univ. Chicago Press, 324 p.

Leviton A. E., and M. L. Aldrich. 1997. Theodore Henry Hittell's The California Academy of Sciences, 1853-1906. Calif. Acad. Sci., San Francisco, 623 p.

M. L. Aldrich, and K. Elsbernd. 2006. The California Academy of Sciences, Grove Karl Gilbert, and photographs of the 1906 earthquake, mostly from the archives of the academy. Proc. Calif. Acad. Sci. 57(1):134

Pawson, D. L., and D. J. Vance. 2010. Austin Hobart Clark (1880-1954): his echinoderm research and contacts with his colleagues. In L. G. Harris, S. Anne Böttger, C. W. Walker, and M. P. Lesser (Editors), Echinoderms: Durham, p. XXV-XXXVI. Taylor and Francis Group, Lond.

Rathbun, R. 1892. The United States Fish Commission: some of its work. The Century 1892:679-697.

Rehbock, P. 1992. At sea with the scientifics. The Challenger letters of Joseph Matkin. Univ. Hawaii Press, Honolulu, 424 p.

Rivinus E. F., and E. M. Youssef. 1992. Spencer Baird of the Smithsonian. Smithsonian Inst. Press, Washington and London, $232 \mathrm{p}$.

Spencer, L. T. 2002. Four men and an Albatross: the growth of American Oceanography, 1882-1921. In K. R. Benson and P. F. Rehbock (Editors), Oceanographic history the Pacific and beyond, p. 288-297. Univ. Wash. Press, Seattle.

Townsend, C. H. 1925. The Passing of the Albatross. Zool. Soc. Bull. 28(3):55-58.

Williams, G. C. 2007. History of invertebrate zoology at the California Academy of Sciences. Proc. Calif. Acad. Sci. 58(12):197-239. 